\title{
Middle School Emergent Bilingual and Bilingual Students' Perspectives on U.S. History
}

\author{
A Dissertation \\ Presented to \\ The Faculty of the Curry School of Education \\ University of Virginia
}

In Partial Fulfillment

of the Requirements for the Degree

Doctor of Philosophy

by

Paul J. Yoder, B.A., M.Ed.

August 2016 
(C) Copyright by Paul J. Yoder All Rights Reserved August 2016 


\section{ABSTRACT \\ Dr. Stephanie van Hover, Advisor}

This dissertation study investigated the historical perspectives of middle school emergent bilingual and bilingual students. The participants in this qualitative multiple case study included eleven seventh grade students from two middle schools in a Virginia school district. Data collection occurred over the course of one semester and included classroom observations, instructional document collection, and individual and focus group interviews.

Data analysis revealed that the participants reflected the official U.S. history curriculum when describing their own historical perspectives. The participants' descriptions of their historical knowledge reflected three schematic narrative templates (Barton \& Levstik, 2004; Carretero \& van Alphen, 2014; Peck, 2010; Wertsch, 2000; Wills, 2011). Students most frequently referenced "the nation-building narrative," which was based on concepts of progress and development. The participants also used "the equality narrative" and "the discrimination narrative." These narratives reflected the importance of rights and inequality, respectively. When describing historical perspectives that reflected the nation-building narrative, students rarely referenced their own experiences or social identities. However, students used the discrimination and equality narratives to bridge the divide between their own social identities and the formal U.S. history curriculum, particularly when comparing the present and the past.

The findings from the present study contribute to research on the historical perspectives of students from culturally and linguistically diverse backgrounds. The findings highlight the potential for the U.S. history taught in schools to mediate students' 
historical perspectives. The findings also suggest that middle school students have the potential to use narratives and other cultural tools to organize complex historical knowledge. Finally, the findings suggest that U.S. history classrooms represent "curricular spaces" (Parker, 2010) in which questions of identity are explicitly and implicitly addressed.

The findings from the present study have potential implications for research and practice. First, the findings add to the existing research on the interaction between student identity and the ways in which emergent bilingual and bilingual students describe their historical perspectives. Second, the findings suggest students may benefit from history instruction that is more culturally and linguistically responsive. Finally, the findings prompt new questions that may inform future research. 


\title{
Curriculum, Instruction, and Special Education Curry School of Education \\ University of Virginia \\ Charlottesville, Virginia
}

\begin{abstract}
APPROVAL OF THE DISSERTATION
This dissertation, "Middle School Emergent Bilingual and Bilingual Students' Perspectives on U.S. History," has been approved by the Graduate Faculty of the Curry School of Education in partial fulfillment of the requirements for the degree of Doctor of Philosophy.
\end{abstract}

Stephanie van Hover, Advisor

Nancy Deutsch

Amanda Kibler

Susan Mintz

June 13, 2016 


\section{DEDICATION}

This work is dedicated to Katrina, Isela, and Matias. 


\section{ACKNOWLEDGEMENTS}

I would like to thank the members of my committee for their insights and valuable advice through this dissertation process. While you each contributed in numerous ways, I want to particularly recognize the following recommendations. Dr. Mintz provided helpful feedback on how to use theory to frame the study. Dr. Deutsch suggested resources and methods to help me prepare for the fieldwork. Dr. Kibler offered critical perspectives on how to think and talk about the students at the heart of this study. Finally, Dr. van Hover, who has walked with me since the first day I came to Curry, provided encouragement and mentoring throughout the process. I have learned so much while studying and working with each of you during my doctoral program.

I also want to express my gratitude to the administrators, teachers, and students who welcomed me into their classrooms. I enjoyed speaking with fellow educators and students about how they make sense of the complex ideas and processes that contribute to our understandings of history. I appreciate the opportunity to share your stories. 


\section{TABLE OF CONTENTS}

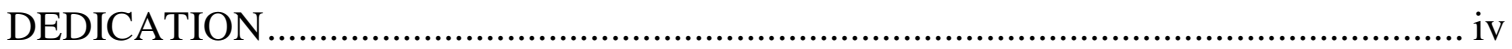

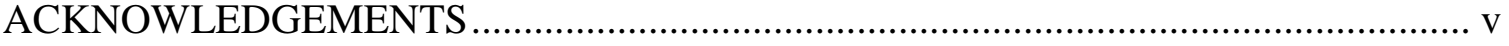

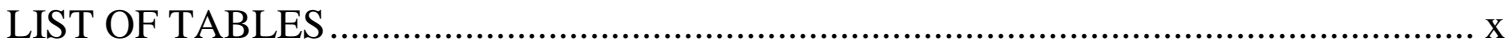

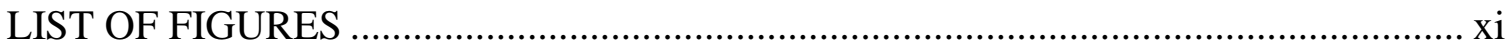

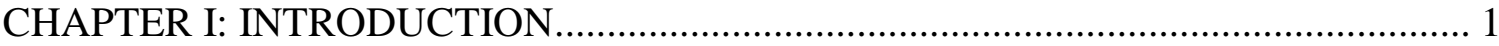

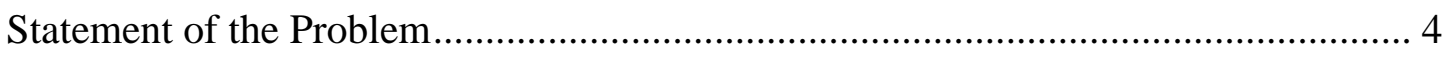

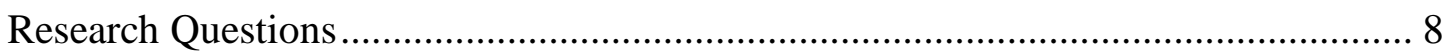

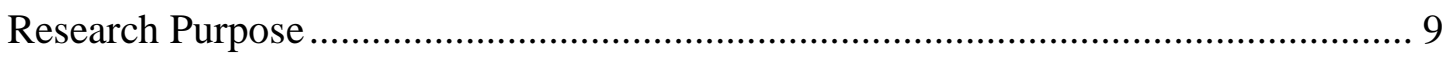

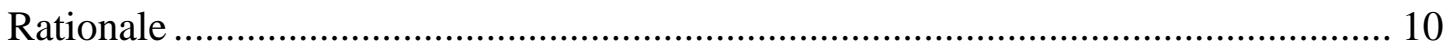

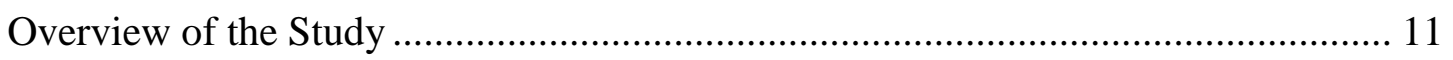

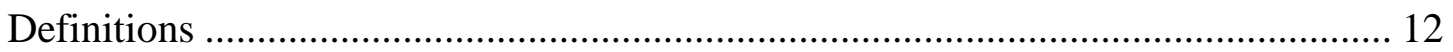

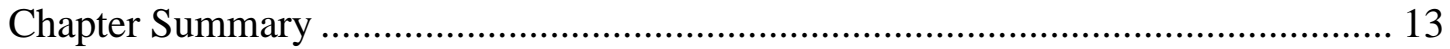

CHAPTER II: REVIEW OF THE LITERATURE ................................................ 15

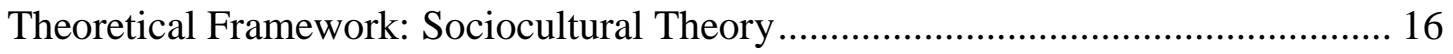

Conceptual Framework: Understanding Students ................................................ 19

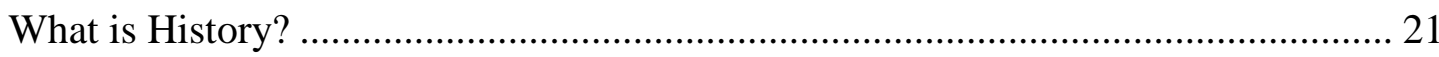

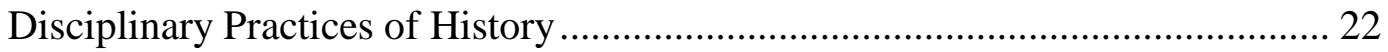

Narratives of U.S. History ........................................................................ 29

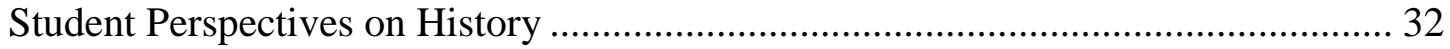

In Black and White: Comparing Student Perspectives by Race ......................... 32

Beyond Black and White: Latina/o Student Perspectives ................................. 36

Immigrant Experience and Perspectives on National History ........................... 40

Religious Background and Historical Perspectives ........................................ 46

Gender and Historical Perspectives ........................................................... 49

Identity Formation among Emergent Bilinguals ................................................ 53

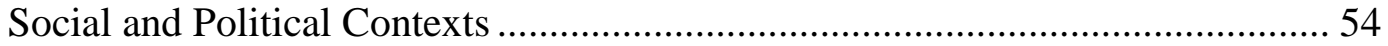

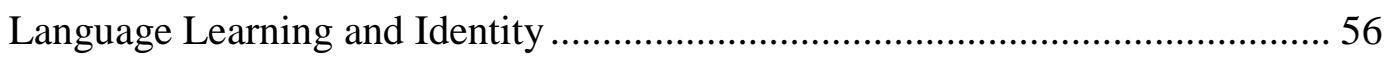

Schooling Experiences and Environments ...................................................... 59

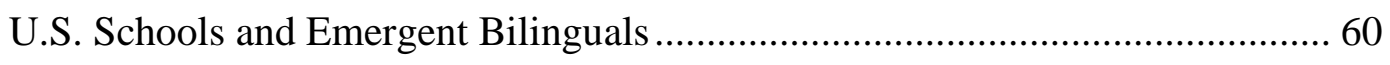




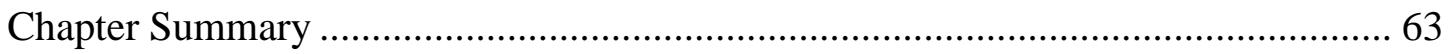

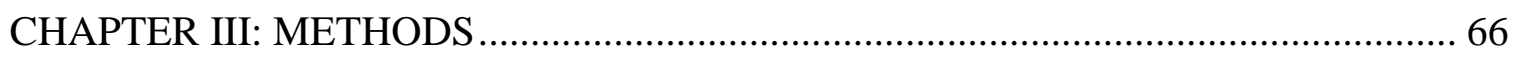

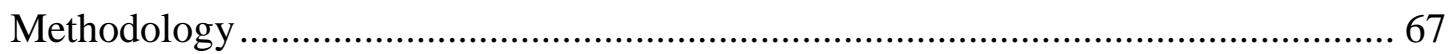

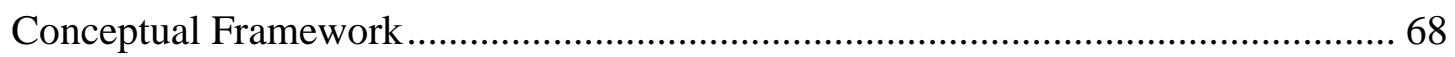

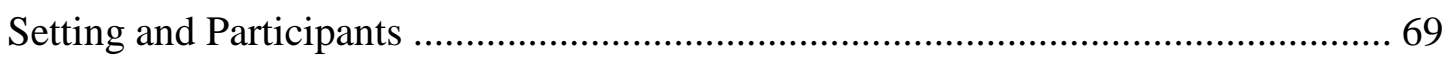

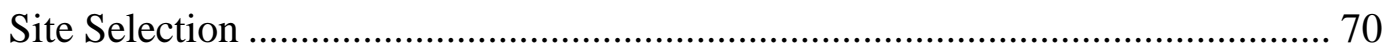

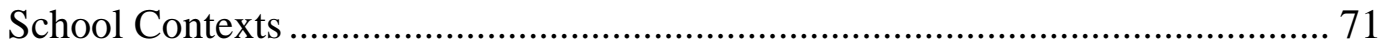

Jackson Heights Middle School............................................................ 71

Garden View Middle School ........................................................... 72

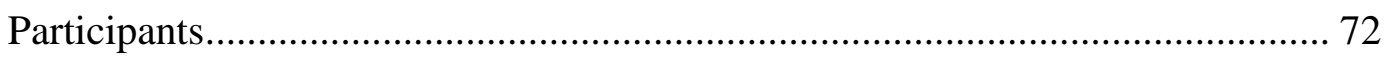

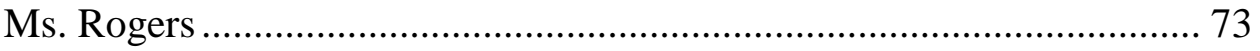

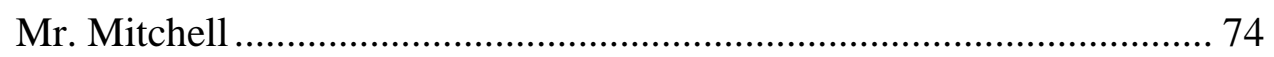

Case Study Students......................................................................... 77

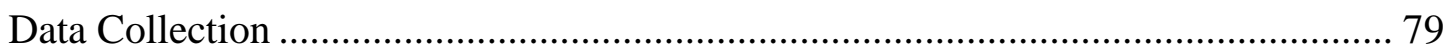

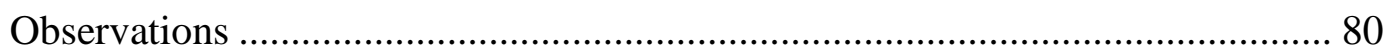

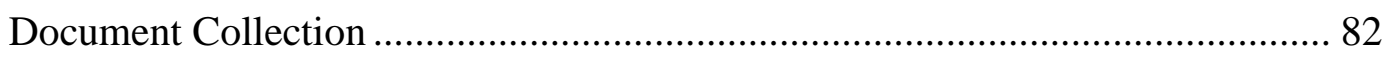

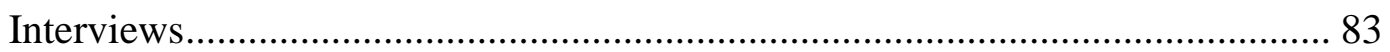

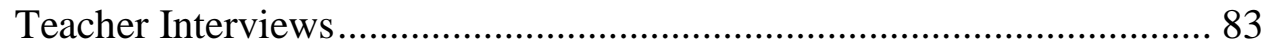

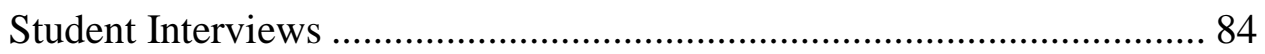

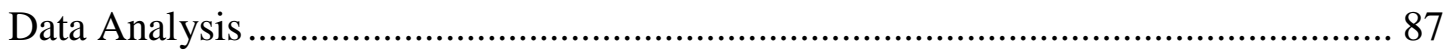

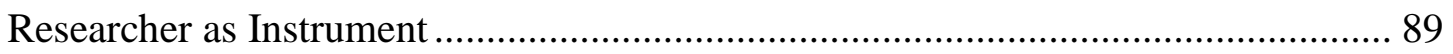

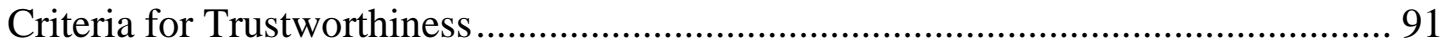

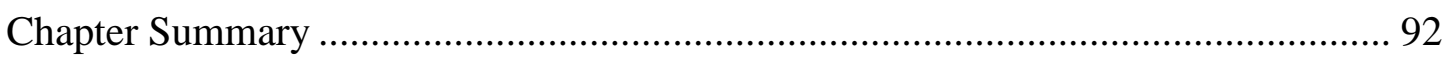

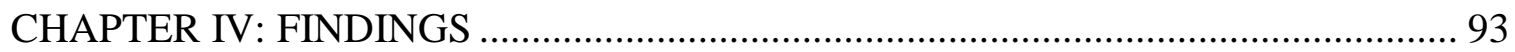

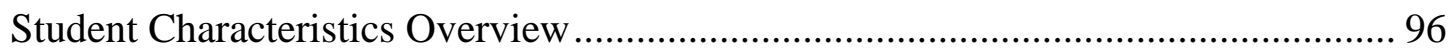

Emergent Narratives in U.S. History ……………….......................................... 105

The Nation-Building Narrative ........................................................................ 107

"Started Building Stuff and Expanding": Events that Shaped the

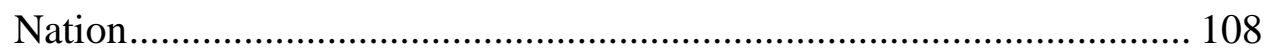

"America was Made by a Couple of People": Important Historical

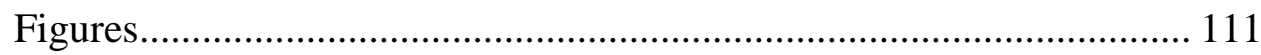

"Because People Did This for Us": Progress and Change....................... 114

The Equality Narrative...................................................................................... 117

"Not Treated Bad, Treated Good": Establishing the Standard of

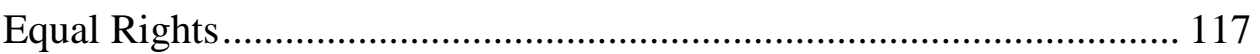

"They were Trying to Fix the World": Conceptualizing Freedom......... 119

"I Have a Dream": Understanding Rights as the Pursuit of Equality.... 122 


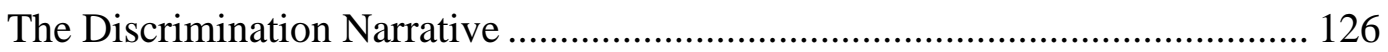

"Blacks were Being Treated Really Bad": Defining Discrimination. .... 127

"We Took Their Land": Identifying Discrimination in U.S. History..... 129

"He is Pretty Much Like Hitler": Comparing the Past and Present........ 134

Interactions between Student Characteristics and Historical Perspectives ................ 136

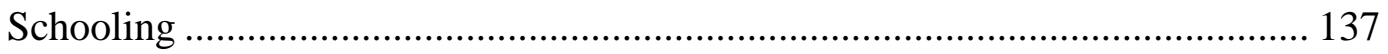

"Everything So I Could Be Ready": History as Academic Subject........ 138

"I Guess They Have to be Important for Us to Learn about Them":

Credible Sources of Historical Knowledge............................................. 143

"Earlier, in Other Grades": The Standards of Learning........................... 146

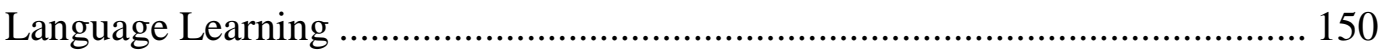

"Bilingual-I speak Spanish and English": Participant Linguistic

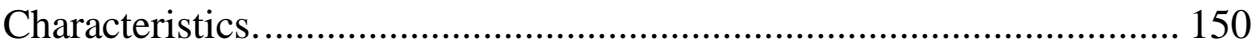

"I Don't Like History a Lot": Student Perceptions of History............... 152

"It's Like a Piece of Cake": Historical Misconceptions......................... 159

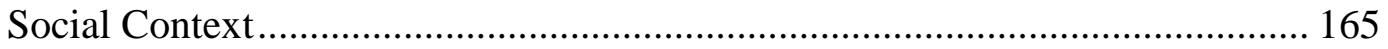

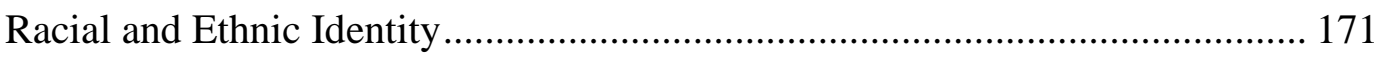

“That's Racist!": Racism and Discrimination........................................... 171

"You Speak Mexican": Language and Ethnic Identity............................ 183

"It's Like Black and White": Perspectives on Historical Racism............ 185

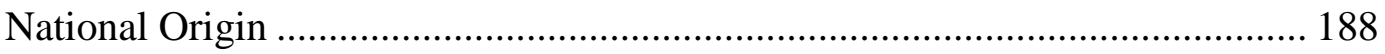

"He's Born Here so He's From Here": Conceptualizing National

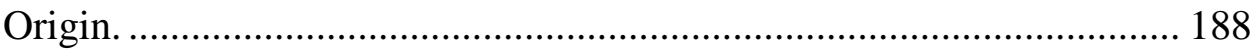

“People Don't Want Syrian Refugees": Contemporary Perspectives on

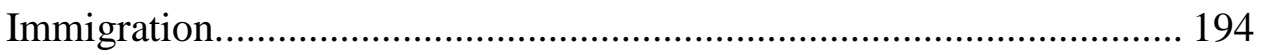

“They Didn't Just Appear”: Perspectives on Historical Immigration. ... 197

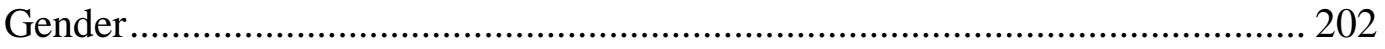

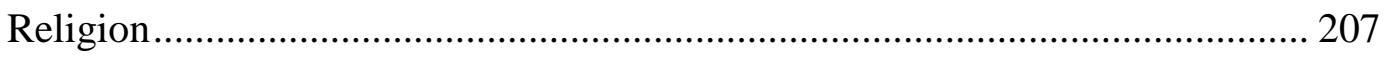

Participant Cases ……........................................................................... 210

"I'm Half American": The Case of Felix.............................................. 210

"I Would Be a Slave": The Case of Maria.............................................. 212

"I Don't Like the American": The Case of Yonas.................................. 214

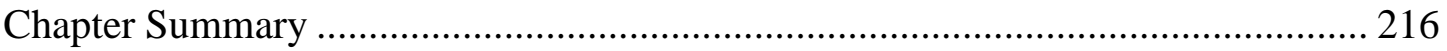

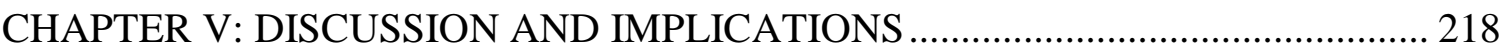

Student Perspectives Reflect the Official Curriculum .............................................. 219

Students Employ Narratives to Organize Historical Perspectives ............................. 222

Students Identify with (In)Equality in U.S. History ……….................................... 226

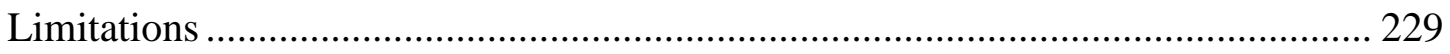

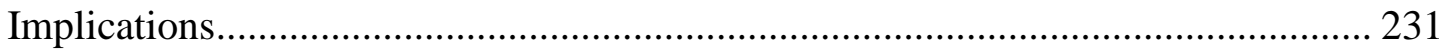




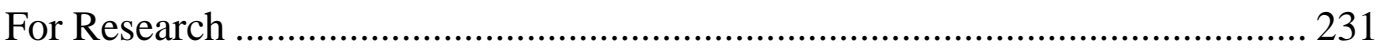

For History Teachers........................................................................... 234

For Teacher Educators ............................................................................ 236

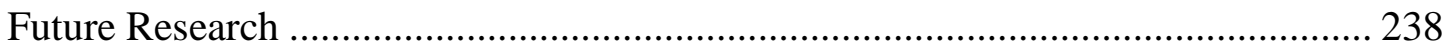

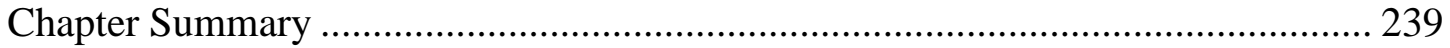

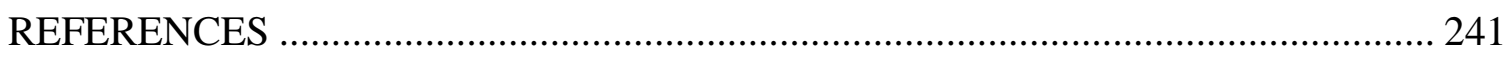

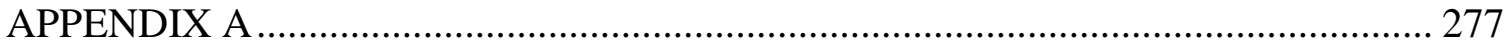

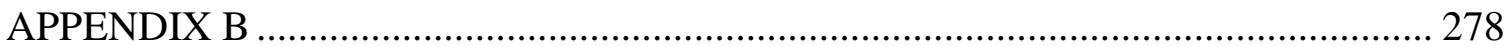

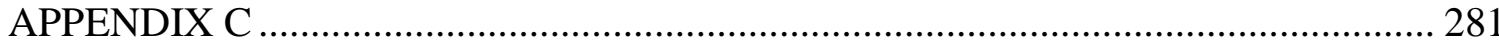

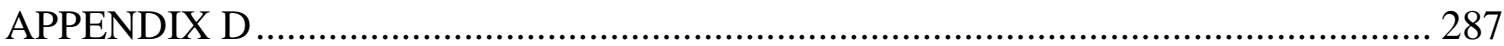




\section{LIST OF TABLES}

TABLE

PAGE

1. Assessment Scoring Rubric for Interpreting an Accounts-Based Question .......25

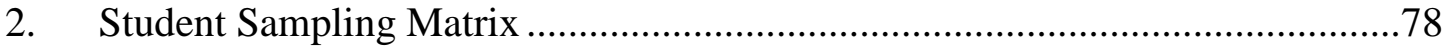

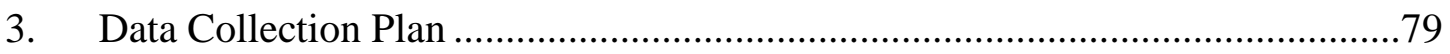

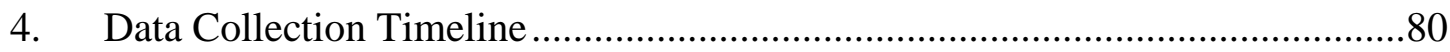

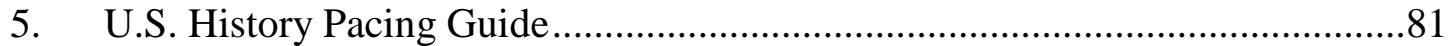

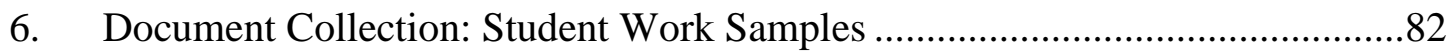

7. Sources of Student Characteristic Data...............................................................

8. Participant Student Demographic Data............................................................97

9. Case Study Students in Ms. Rogers' Class …………………………..................99

10. Case Study Students in Mr. Mitchell's Class.....................................................102

11. Schematic Narrative Templates found within Participants' Historical

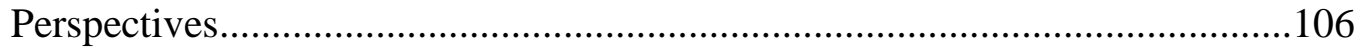

12. Student Nominations for Most Important Events in U.S. History .....................110

13. Student Nominations for Most Important People in U.S. History .....................111

14. Student Nominations for Credible Sources of History .....................................143

15. Student Nominations for Most Important People in U.S. History and the

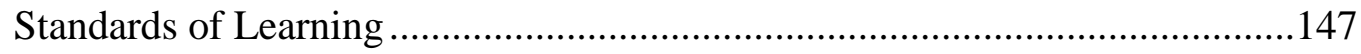

16. Student Nominations for Most Important Events in U.S. History and the

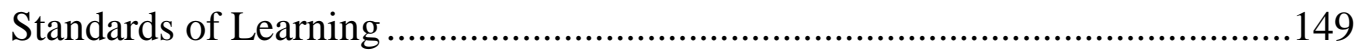

17. Comparing Students' Narratives of National History........................................223 


\section{LIST OF FIGURES}

FIGURE

PAGE

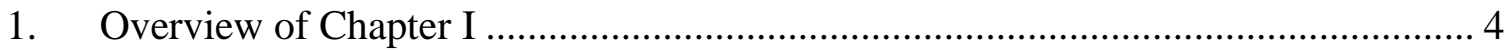

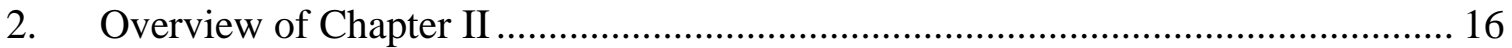

3. Understanding the Historical Perspectives of (Emergent) Bilinguals .................... 19

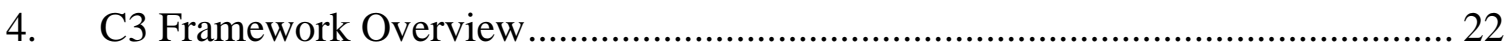

5. C3 Framework: Applying Disciplinary Tools and Concepts ................................ 24

6. Student Characteristics Expected to Interact with Emergent Bilingual

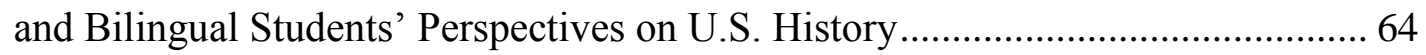

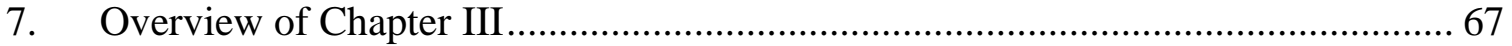

8. Understanding the Historical Perspectives of (Emergent) Bilinguals .................... 69

9. Emergent Findings Presented in Final Student Interviews ................................... 86

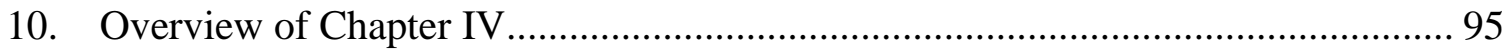

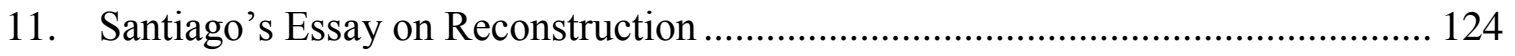

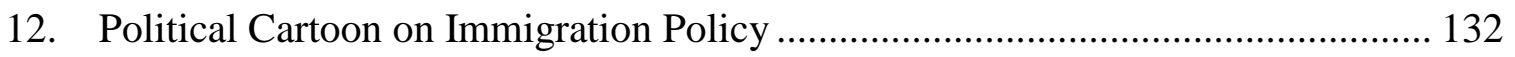

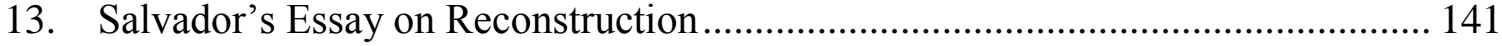

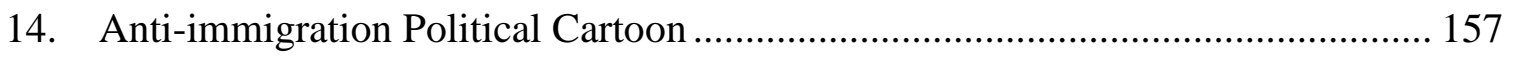

15. Five Points (New York City) Tenement Photograph......................................... 158

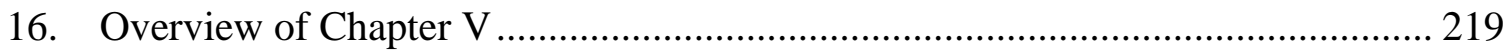

17. Ambitious Teaching and Learning of U.S. History for (Emergent) Bilinguals Framework 


\section{CHAPTER I}

\section{INTRODUCTION}

Recent demographic changes in U.S. schools have contributed to the formation of a "new majority" (Sleeter, 1996) or "new mainstream" (Enright, 2011) in which a culturally and linguistically diverse student population is increasingly common. Many students grow up speaking one or more languages other than English at home. Based upon the "curricularized" frameworks of language found in U.S. schools (Kibler \& Valdés, 2016; Valdés, 2015), a variety of institutional labels are applied to such students, including Limited English Proficient (No Child Left Behind [NCLB], 2002), English Language Learner (ELL; Hirvela, 2010), and emergent bilingual (García, Kleifgen, \& Falchi, 2008). In the present study I employ the term "emergent bilingual" to reflect the perspective that "through school and through acquiring English, these children become bilingual, able to continue to function in their home language as well as in English" (García et al., 2008, p. 6). In order to distinguish between those students categorized as "acquiring English" and those said to "function" in English (García et al., 2008), I use the term "bilingual" to describe students who were previously identified as emergent bilingual (Palmer \& Martínez, 2013). Within the course of this study I also seek to be "wordy" in my descriptions of individuals and groups of students in recognition that "single labels are imprecise, often negative and sometimes misleading" (Valdés, 2016).

The most recent national data suggest that nine percent of K-12 students are emergent bilinguals (Office of English Language Acquisition, 2015c), with the 
percentage of emergent bilinguals growing faster than the overall student population (Center for Public Education, 2012; National Clearinghouse for English Language Acquisition, 2011). Many states that have traditionally had a lower density of emergent bilinguals have recently experienced particularly sharp growth in the number of emergent bilinguals, most notably seven states primarily in the Midwest and Southeast who have seen their emergent bilingual populations double in the past decade (Office of English Language Acquisition, 2015c). These data present a clear picture of the presence and ongoing growth in the number of emergent bilinguals, suggesting that schools and educators must be prepared to teach culturally and linguistically diverse students (Bunch, 2010, 2013; DiCerbo, Anstrom, Baker, \& Rivera, 2014; Enright, 2011; Lucas \& Villegas, 2010; Lucas, Villegas, \& Freedson-Gonzalez, 2008).

The goals related to teaching and learning social studies — and history in particular - apply in a special way to the needs of emergent bilinguals, many of whom are immigrants or the children of immigrants. In the College, Career and Civic Life (C3) Framework, the National Council for the Social Studies (NCSS) identifies the preparation of "knowledgeable, thinking, and active citizens" (2013, p. 5) as the primary goal of teaching social studies. Parker (2010) contends that history classes, in particular, are "curricular spaces where identities are deliberately shaped" as students encounter “existential questions — questions about our founding myths, our master narratives, who 'we the people' are and ought to be" (p. 247). As "curricular spaces" in which a definition of who and what is "American" is articulated through the histories that are presented (Cornbleth \& Waugh, 1999; Evans, 2004; Nash, Crabtree, \& Dunn, 2000; Sleeter, 1996), U.S. history classrooms have the potential to play an important role as 
students—particularly emergent bilingual and bilingual students—address Parker's "existential questions" while also negotiating identity across culturally and linguistically diverse settings (see also Carretero, Asensio, \& Rodríguez-Moneo, 2012).

Yet scholars who study the experience of culturally and linguistically diverse students in U.S. schools argue that social interactions and the official curriculum often have a negative influence on students' identity formation and sense of belongingparticularly among immigrant youth (Olsen, 1997; Suárez-Orozco et al., 2010; SuárezOrozco, Suárez-Orozco, \& Todorova, 2008; Turkan \& DaSilva Iddings, 2012; Valdés, 1996; Valenzuela, 1999). Research has also demonstrated that in the process of learning U.S. history students of color often reframe or resist the master narrative when it conflicts with their own histories (Almarza, 2001; Busey, 2013; Choi, Lim, \& An, 2011; Epstein, 2000, 2009). In the few studies that directly address immigrant students' perspectives on the teaching and learning of history, the findings indicate that the length of time in a new country may impact the meaning making of students in varied ways as they encounter new historical narratives (An, 2009; Choi et al., 2011; Levy, 2014; Peck, 2010). Researchers involved in this line of inquiry call for more study into the unique experiences and historical perspectives of students from immigrant families.

In short, at a time when increasing numbers of social studies and history teachers have emergent bilinguals and bilingual students in their classes, research highlights both the importance and complexity of the teaching and learning of history among linguistically and culturally diverse students. In the remainder of chapter one, I first articulate the statement of the problem. I follow this with the research questions for the present study. I then describe the research purpose and rationale for the study. Next, I 
provide an overview of the study design. Finally, I conclude by defining key terms and summarizing the chapter. Figure 1 provides a complete overview of the chapter.

Statement of the Problem

\section{Overview of Chapter I}

Research Questions

Research Purpose

Rationale

Overview of the Study

Definitions

Chapter Summary

Figure 1. Overview of Chapter I

\section{Statement of the Problem}

The present study is in response to the call for more research on the teaching and learning of history among emergent bilinguals. Research indicates that classroom instruction routinely fails to provide emergent bilinguals with adequate access to the "language of schooling" (Schleppegrell, 2004) through which content area knowledge is taught and learned (Aukerman, 2007; O. Lee, Quinn, \& Valdés, 2013; Schleppegrell, 2004). Data published by the U.S. Department of Education indicate that the resulting barriers correspond to lower assessment scores in math and reading among emergent bilinguals (Office of English Language Acquisition, 2015b), as well as higher percentages of emergent bilinguals being "held back" or retained (Office of English Language Acquisition, 2015d) and lower percentages of emergent bilinguals graduating from high school (Office of English Language Acquisition, 2015a). The language of school history presents students with particular challenges in the form of densely packed phrases, abstract nouns, and passive verbs (e.g., C. L. Brown, 2007; de Oliveira, 2011; Schleppegrell, Achugar, \& Oteiza, 2004; Schleppegrell \& de Oliveira, 2006; Schleppegrell, Greer, \& Taylor, 2008). 
As the number of emergent bilinguals in U.S. schools has increased, the number of social studies educators teaching emergent bilinguals has also grown. Results from the nationally representative Survey on the Status of Social Studies indicate that half of all social studies teachers have emergent bilinguals in their classes (Jimenez-Silva, Hinde, \& Hernandez, 2013). Middle school social studies teachers were the most likely to have emergent bilinguals in their classrooms, with $57.9 \%$ reporting that they teach emergent bilinguals (Jimenez-Silva et al., 2013). The large number of social studies teachers with emergent bilinguals in their classes presents significant implications for the teaching and learning of social studies and history.

Initial research in response to the growing number of emergent bilinguals has focused on teacher perspectives regarding inclusion of emergent bilinguals in mainstream classes and teachers' abilities to meet the needs of emergent bilinguals. In a series of survey-based studies, research has documented that social studies teachers report a number of challenges to providing instruction appropriate for emergent bilinguals. For example, among the half of Survey on the Status of Social Studies respondents who reported teaching emergent bilinguals, the two most cited barriers were inadequate instructional materials (31.1\%) and insufficient time (27.6\%; Jimenez-Silva et al., 2013). The third most prevalent barrier was identified by those teachers who said they "were not sure how to provide for [emergent bilinguals'] needs" (22.5\%; Jimenez-Silva et al., 2013, p. 284). These findings align with Cho and Reich's (2008) survey of Virginia high school social studies teachers $(N=33)$ who identified a language barrier and limited student prior knowledge as leading challenges, with over a third of the teachers reporting that limited school supports, as well as a "lack of time and resources to devote to 
[emergent bilinguals]"' (p. 237) created issues. O'Brien $(2009,2011)$ similarly surveyed high school social studies teachers in a Florida school district. Half of the participants $(n=123)$ disagreed with the following statement: "I had adequate training in college courses to teach [emergent bilinguals] students effectively" (O'Brien, 2011, p. 27). Research using qualitative approaches has yielded comparable findings, with teachers identifying "woefully inadequate textbooks" (Hilburn, 2014, p. 663) and a "fragmented" official curriculum (Yoder \& van Hover, 2015) as hurdles to providing emergent bilinguals with appropriate instruction. The recurring themes of lack of time, adaptable resources and professional training in the research literature highlight the need for understanding of the teaching and learning of history among emergent bilinguals, as well as increased supports for history and social studies teachers, including targeted instructional materials and teacher training.

The extant research provides few examples of culturally diverse students' perspectives on and experiences of learning U.S. history and suggests that more research is needed. Research in the field of history education suggests that the process of immigrating impacts the meaning making of students learning history (An, 2009; Choi et al., 2011; Levy, 2014; Peck, 2010). However, the empirical research in the field of history education has largely omitted emergent bilinguals, at times intentionally (e.g., Busey, 2013) or through setting "background knowledge" inclusion criteria (e.g., Peck, 2010). While Franquiz and Salinas (2011) and others (e.g., Yoder \& van Hover, 2015) have studied the classroom practices of history teachers with emergent bilinguals, much of the extant research focuses more on language acquisition than students' historical perspectives or consciousness (Yoder, Kibler, \& van Hover, 2016). As a result, scholars 
in both the field of history education (e.g., Barton, 2008; Barton \& Avery, 2016; O'Brien, 2012) and second language acquisition (Amaral \& Garrison, 2007; Colombo \& Fontaine, 2009; Janzen, 2008; Vaughn et al., 2009) have called for additional research into the teaching and learning of history among emergent bilinguals and their bilingual classmates.

This study investigated the historical perspectives of emergent bilingual and bilingual students in two classrooms. Operating from a sociocultural perspective that is common in the field of history education (Barton \& Levstik, 2004) and has increasing currency in the field of second language acquisition (Lantolf, 2011; Lantolf \& Thorne, 2006), the study operationalized an emergent conceptual framework that draws on Grant's (2003) notions of ambitious teaching and learning of history and its three tenets: subject knowledge, understanding students, and creating space for learning. The present study also built on the Grant and colleagues' (Grant, 2003, 2010; Grant \& Gradwell, 2010; Grant \& Salinas, 2008) literature on the teaching and learning of history within standards-based settings, as the study was conducted in Virginia, a state with a statemandated history curriculum (see, for example, van Hover, 2006; van Hover, Hicks, Stoddard, \& Lisanti, 2010; Yoder \& van Hover, 2015).

This study was conducted in a middle school setting as both theory (Erikson, 1959, 1968) and empirical research (Phinney, 1992; Williams, Anderson, Francois, Hussain, \& Tolan, 2014; Woolley, Kol, \& Bowen, 2009) in the field of psychology identify early adolescence as a time when students begin wrestling with Parker's (2010) “existential questions” regarding history and identity. Furthermore, Epstein's (2009) investigation of the perspectives of White and Black students suggests that during middle 
school students' self-reported meaning making begins to vary substantially along social group (i.e., racial) lines. Also, the majority of studies into the unique learning of national history among culturally diverse students have been among high school students (e.g., Epstein, Mayorga, \& Nelson, 2011; Martell, 2013; Peck, 2010). As such, the study was conducted among middle school emergent bilingual and bilingual students in order to draw on their conceptually rich positionality, as well as to address the gap in the literature.

\section{Research Questions}

The research questions for the present study are as follows:

- How do middle school emergent bilingual and bilingual students describe their perspectives on U.S. history?

- How do various student characteristics (e.g., English language proficiency, country of origin) interact with middle school emergent bilingual and bilingual students' perspectives on U.S. history?

The research questions foreground middle school emergent bilingual and bilingual students' perspectives and meaning making in the process of the teaching and learning of U.S. history as a greater understanding of students provides for more effective instruction (Grant, 2003; Yoder, Kibler, \& van Hover, 2014). The study operationalized a sociocultural paradigm in which the teacher perspectives and observed classroom practices help to describe the context within which the students encounter and make meaning of the U.S. history curriculum. 


\section{Research Purpose}

The primary goal of the present study is to contribute to the knowledge base on the teaching and learning of history among culturally and linguistically diverse students, most notably emergent bilingual and bilingual students. The need for empirical research that bridges the fields of history education and second language acquisition has been well documented (Amaral \& Garrison, 2007; Colombo \& Fontaine, 2009; Janzen, 2008; O'Brien, 2012; Vaughn et al., 2009; Yoder, 2013; Yoder et al., 2016). The views of emergent bilingual and bilingual students are particularly needed, given the evidence that some students of color reject or re-negotiate the traditional U.S. narrative of progress and freedom (Almarza, 2001; Busey, 2013; Choi et al., 2011; Epstein, 2000, 2009; Peck, 2010) and the lived experience of immigration impacts student perspectives on history (An, 2009; Choi et al., 2011; Levy, 2014; Peck, 2010). However, Duong and colleagues (2015) argue that little research bridges the role of immigrant experience and emergent bilingual status. Similarly, no studies have integrated insights from second language acquisition research on identity as a lens through which to examine the experiences and perspectives of emergent bilingual and bilingual students in the course of the teaching and learning of history. As such, the present study has the potential to contribute to the theoretical understanding of how the interplay between language and identity may impact the learning of history among culturally and linguistically diverse student populations.

A growing body of research stresses the need for mainstream content teachers to be prepared to teach emergent bilinguals (Bunch, 2010, 2013; DiCerbo, Anstrom, Baker, \& Rivera, 2014; Enright, 2011). Yet Valdés and colleagues (2014) identify two challenges facing teachers, namely the disciplinary language practices present within the 
various content areas, and the need to provide effective instruction that is accessible to emergent bilinguals. Research specific to history teachers suggests that classroom teachers do not receive the training they need to meet the needs of emergent bilinguals (Cho \& Reich, 2008; Jimenez-Silva et al., 2013; O'Brien, 2009, 2011). The same research finds that history teachers also lack the curricular and instructional resources to adequately support the unique cultural and linguistic needs of emergent bilinguals (Cho \& Reich, 2008; Jimenez-Silva et al., 2013; O'Brien, 2009, 2011), indicating that as researchers develop a greater understanding of the experiences of emergent bilinguals these findings must be disseminated to history teachers and teacher educators, as well as those involved in curriculum development (e.g., textbook publishers) and the policymakers responsible for writing content standards.

\section{Rationale}

A better understanding of today's "new mainstream" (Enright, 2011) of culturally and linguistically diverse students is needed so that history educators can provide instruction that responds to the unique cultural and linguistic needs of emergent bilingual and bilingual students. The present study incorporated emergent bilingual and bilingual students' perspectives and contributed both to the literature on the viewpoints of students of color (Epstein, 2000, 2009; Peck, 2010) and the sense making of students from immigrant families (Olsen, 1997; Suárez-Orozco et al., 2010; Suárez-Orozco et al., 2008). In unpacking middle school students' notions of language, identity, and history, participants' local and nationalized sense of belonging played an important role (Epstein, 2009; Norton, 2000; Norton Peirce, 1995). 


\section{Overview of the Study}

Building upon a sociocultural theoretical framework, the present study applied a multiple case study design (Creswell, 2009) to the investigation of middle school emergent bilingual and bilingual students in two U.S. history classes. The primary goal of this qualitative research study is to better understand the perspectives on U.S. history middle school emergent bilingual and bilingual students espouse. An interpretivist paradigm informed the collection and analysis of data in order to recognize the positionality of both the participants and the researcher (Flyvbjerg, 2001), building on an ontology that assumes multiple realities (Guba \& Lincoln, 1994). In order to capture the multiple experiences and perspectives present among U.S. emergent bilingual and bilingual students (Aud et al., 2012), focal students were purposefully selected through extreme case (Teddlie \& Tashakkori, 2009) or maximum variation sampling (Marshall \& Rossman, 2011). Data sources included classroom observations and document analysis. Student interviews and focus groups were also used as a means of eliciting emic perspectives (Erickson \& Schultz, 1992; Marshall \& Rossman, 2011). As part of the bounded case study, teacher data was used to better understand the experiences of students within the classroom, as learning occurs and is influenced by shared experiences (Erickson \& Schultz, 1992; Hawkins, 2004; Nieto, 1999, 2000). In addition to the triangulation of multiple data sources, the writing of analytic memos, member checking, and prolonged observation served to strengthen the trustworthiness of the study (Erickson, 1986; Krefting, 1999). 


\section{Definitions}

In recognition of the "power of labels" in research involving culturally and linguistically diverse students (Addy, 2015), I have generally adopted the terms (e.g., White, Latino, African American) researchers or participants used in a given context. Yet, as the present study draws on literature from multiple fields of study, several key terms must be defined according to their use within this study. I employed the following definitions in the course of the review of literature and the present study:

- Bilingual student — a student who has been identified as speaking a language other than English and is also said to be fluent in English (García, 2010). In the context of the present study, I use the term "bilingual" to signify that a student is a “former" emergent bilingual (Athanases \& de Oliveira, 2014) who the school previously provided with English as Second Language (ESL) services, but who has since "Exited" those services after testing at the Level 6 "Reaching" level on WIDA assessments of English language proficiency (The Board of Regents of the University of Wisconsin System, 2014).

- Emergent bilingual - a student identified as being a speaker of one or more languages other than English who is learning English in order to achieve academic success (García, 2010; García et al., 2008), given the assumption that all students must learn English in order to access instruction in U.S. schools (García, 2009; Kibler, Valdés, \& Walqui, 2014).

- Historical perspectives - “the assumptions, knowledge, and values that shape historians' and others' judgments about the meaning and significance of historical actors, events, institutions, and processes" (Epstein, 1998, p. 398). 
- Identity - the way in which individuals articulate their position in society, particularly in regard to culture and ethnicity (Banks, 2002; Norton, 2000; Peck, 2010). The related terms of citizen and citizenship have been deliberately avoided as research suggests that immigrant students — and the teachers of immigrants students - often associate these terms with legal status and documentation (e.g., Dabach, 2014; Mangual Figueroa, 2012; Worthy, Durán, Hikida, Pruitt, \& Peterson, 2013) rather than participatory notions of civic engagement (e.g., Parker, 2008).

- Immigrant - an individual who resides in the United States after being born in another country (NCLB, 2002; Duong, Badaly, Liu, Schwartz, \& McCarty, 2015; Suárez-Orozco et al., 2008).

- Official curriculum - the state-mandated history and social science curriculum that the state of Virginia articulates in the Standards of Learning and related curricular documents (e.g., van Hover et al., 2010, Virginia Department of Education, 2008a).

- Students of color - any student that is labeled as or identifies as being of a race or ethnicity other than White or Caucasian (Nieto, 2013; Tatum, 2003).

\section{Chapter Summary}

The growing numbers of emergent bilingual and bilingual students in classrooms across the United States (Center for Public Education, 2012; National Clearinghouse for English Language Acquisition, 2011) highlights the need for culturally and linguistically responsive U.S. history instruction as a matter of social justice (Epstein, 2009). Yet even as half of U.S. history teachers report having emergent bilinguals in their classrooms 
(Jimenez-Silva et al., 2013), many history teachers also report feeling unprepared to provide appropriately differentiated instruction for these students (Cho \& Reich, 2008; O'Brien, 2009, 2011). Given the great need and lack of research-based answers, many scholars have called for increased empirical study on the teaching and learning of history among emergent bilingual and bilingual students (e.g., Barton \& Avery, 2016; Janzen, 2008; O'Brien, 2012; Yoder, 2013; Yoder et al., 2016).

In response, I employed a qualitative research design (Creswell, 2009) in the present study in order to investigate the situated perspectives of middle school emergent bilingual and bilingual students in the context of two seventh grade U.S. history classrooms. The findings contribute to the extant literature on how students make sense of U.S. history (Barton \& Avery, 2016). These findings address key conceptual questions related to the role of language and identity in the teaching and learning of national history, as well as yield suggestions for history instruction among emergent bilingual and bilingual students, teacher education and future study.

In the next chapter, I review the literature related to the teaching and learning of history among culturally and linguistically diverse students, organizing the analysis around the pillars of subject knowledge, understanding students, and creating a space for learning (Grant, 2003), as outlined in the conceptual framework. I examine empirical and theoretical scholarship from multiple fields, particularly history education and second language acquisition. In the third chapter, I describe the methodology for the present chapter, building on sociocultural perspectives and an interpretivist research paradigm through the outlining of qualitative inquiry in the form of a multiple case study. 


\section{CHAPTER II \\ REVIEW OF THE LITERATURE}

The purpose of the review of literature is to identify insights and questions from the extant scholarship that informed the present study. The present study investigated middle school emergent bilingual and bilingual students' perspectives on U.S. history, including both participant perspectives and classroom practices. In this chapter I review the extant literature, examining empirical and theoretical understandings from the fields of history education and second language acquisition, while also drawing on multicultural education and related bodies of knowledge. This literature review serves as a basis for the research approaches employed in the study in response to the following research questions:

- How do middle school emergent bilingual and bilingual students describe their perspectives on U.S. history?

- How do various student characteristics (e.g., English language proficiency, country of origin) interact with middle school emergent bilingual and bilingual students' perspectives on U.S. history?

In the first section of the chapter I articulate the theoretical framework that provides a foundation for the literature review and the study. I then describe how I used sociocultural theory to approach the research questions through presenting my conceptual framework, which builds on Grant's (2003) notions of ambitious teaching and learning of 
history and the concepts of subject knowledge, understanding students, and creating a space for learning. Given the focus on student perspectives inherent in the research questions, the review of the literature and the present study focus on "understanding students," with Grant's notions of "subject knowledge" and "creating a space for learning" serving to introduce and lay the groundwork for analysis. The review of the literature demonstrates that a gap exists in the research regarding the interaction between student characteristics (i.e., experiences and identities) and historical perspectives on U.S. history. This dearth of empirical scholarship leads to the present study, which explores the historical perspectives of middle schools emergent bilingual and bilingual students. Figure 2 provides a complete overview of the chapter.

Theoretical Framework: Sociocultural Theory

Conceptual Framework: Understanding Students

What is History?

Disciplinary Practices of History

Narratives of U.S. History

Student Perspectives on History

In Black and White: Comparing Student Perspectives by Race

Beyond Black and White: Latina/o Student Perspectives

Immigrant Experience and Perspectives on National History

Religious Background and Historical Perspectives

Gender and Historical Perspectives

Identity Formation among Emergent Bilinguals

Social and Political Contexts

Language Learning and Identity

Schooling Experiences and Environments

U.S. Schools and Emergent Bilinguals

Chapter Summary

Figure 2. Overview of Chapter II

\section{Theoretical Framework: Sociocultural Theory}

I use sociocultural theory as the theoretical framework for the review of the literature and the present study as it allows for the incorporation of complex notions of 
identity in the examination of student characteristics and students' historical perspectives. Barton and colleagues (Barton, 2001; Barton \& Avery, 2016; Barton \& Levstik, 2004; Barton \& McCully, 2005, 2010) argue that the field of history education can benefit significantly by drawing on sociocultural theory in order to better understand how students make meaning of the historical narratives they encounter. The recent "social turn" (Block, 2003; Johnson, 2006; Ortega, 2011, 2013) in the field of second language acquisition has also led to increased attention to research from a sociocultural perspective (see, for example, Lantolf, 2011; Lantolf \& Thorne, 2006). As such, the present study seeks to draw from and contribute to emergent bodies of knowledge regarding both the teaching and learning of history and approaches to the schooling of emergent bilingual and bilingual students.

Sociocultural theory builds on a Vygotskian understanding of the role of mediated action and human interaction in the meaning making and learning processes. Wertsch (1991) emphasized the role of mediation in human action, suggesting that a description of classroom activities should not be limited to what a teacher or student (the individual) is doing, but should instead be based upon an "individual(s)-acting-with-mediationalmeans" (p. 12) formula, in which instructional tools and the role of language are identified as fundamental to the understanding of educational practice. "From this standpoint, human action is understood as involving an irreducible tension between active agents and cultural tools provided by a sociocultural setting" (Wertsch, 2000, p. 47). In outlining research practices related to language learning and literacy, Hawkins (2004) similarly focused on the role of context, describing classrooms as

complex ecosystems, where all of the participants, the practices, the beliefs, the forms of language, the forms of literacies, the social, historical, institutional 
context(s), the identity and positioning work, the politics and power relations, the mediational tools and resources, the activity and task designs, and the influences of the multiple local and global communities within which they are situated come together in fluid, dynamic, and ever-changing constellations of interactions, each one impacting the other. (p. 21)

Researchers who investigate the teaching and learning of history have particularly recognized the role that sociocultural contexts - both within the classroom and in broader society_ play in mediating learning. For example, Barton and McCully (2005, 2010) found that secondary students' schooling, geography, and social identity influenced their learning of history in Northern Ireland. Within a sociocultural framework these characteristics serve to mediate societal and classroom processes alike. Historical narratives — “temporally ordered sequences of events that are causally linked" (Barton, 2001, p. 883) — also serve as key mediators of the teaching and learning history (VanSledright, 2008; Wertsch, 2000; Wills, 2011). The sociocultural contexts in which schools are situated also impact teaching and learning practices, with researchers highlighting the role of such factors as history, economics, culture, politics, and identity (K. D. Brown, 2011; Darling-Hammond, French, \& Garcia-Lopez, 2002; Esteban-Guitart \& Moll, 2014; Hess \& McAvoy, 2015; Nieto, 2013). In the present study, the scope of inquiry focused primarily on the "classroom ecosystem" (Hawkins, 2004), with the “mediated action" (Wertsch, 1991) of emergent bilingual and bilingual students at the heart of the study. Sociocultural theory provides a comprehensive theoretical framework in which to situate this analysis. In order to build upon the theoretical framework outlined above and further conceptualize the factors that may influence the historical perspectives of emergent bilingual and bilingual students, I next describe the conceptual framework that guided the planning and implementation of the present study. 


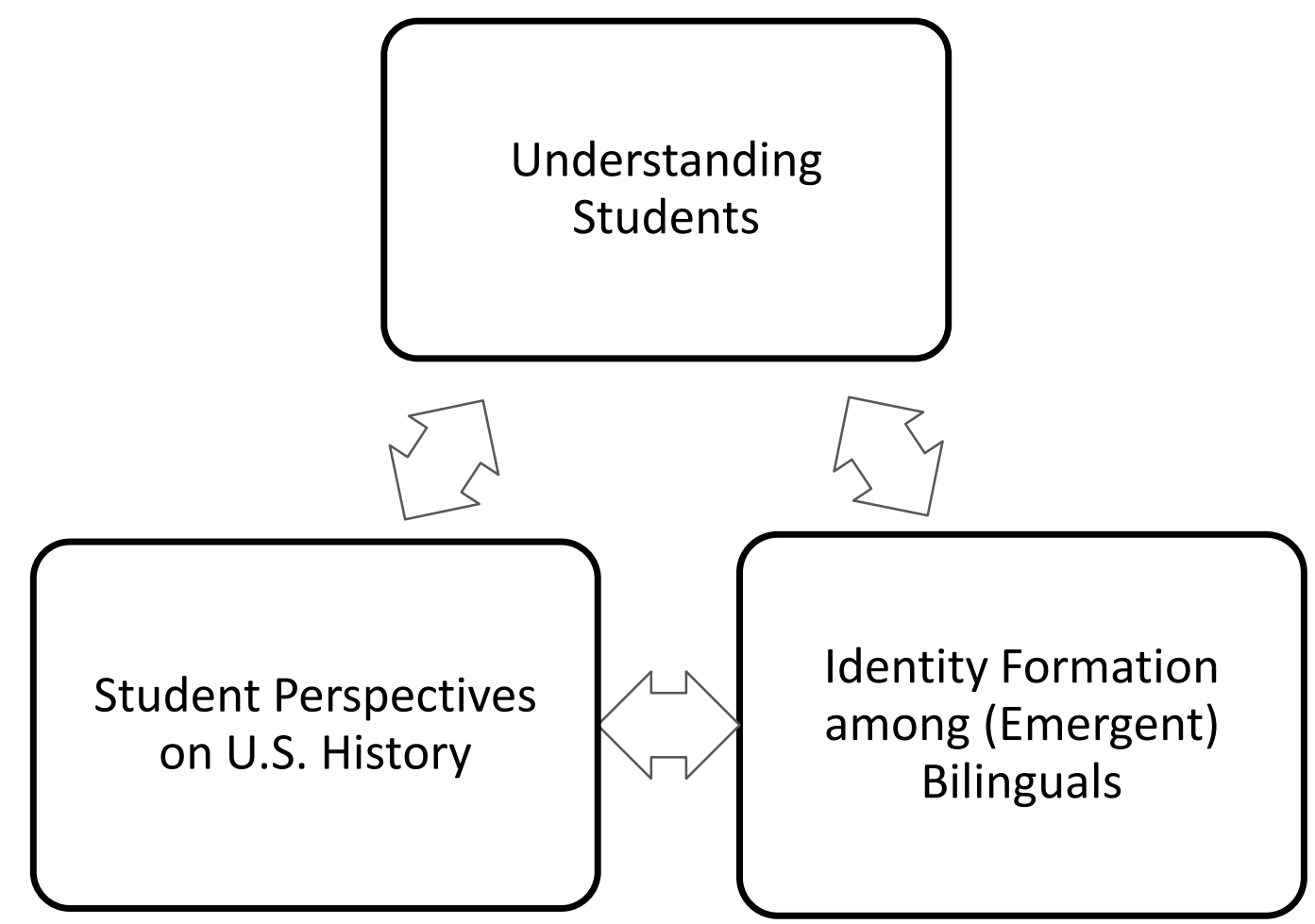

Figure 3. Understanding the Historical Perspectives of (Emergent) Bilinguals

\section{Conceptual Framework: Understanding Students}

From a sociocultural perspective, identifying the "cultural tools" that mediate interaction and meaning making is a critical first step in the study of emergent bilingual and bilingual students' historical perspectives. In this section, I outline the conceptual framework that served as a heuristic (see Figure 3) for addressing the research questions (Coffey \& Atkinson, 1996; Marshall \& Rossman, 2011). This conceptual framework aids in applying theoretical understandings to the situated nature of history learning and the particular context of emergent bilingual and bilingual students. Given the students' unique cultural and linguistic positionality and the resulting diversity present within the classroom, I have chosen to draw from Grant's (2003) notions of ambitious teaching and learning of history:

Ambitious teaching and learning develops (a) when teachers know well their subject matter and see within it the potential to enrich their students' lives; (b) 
when teachers know their students well, which includes understanding the kinds of lives they lead, how they think about and perceive the world, and that they are capable of far more than they and most others believe; and (c) when teachers know how to create the necessary space for themselves and their students in environments that may not appreciate the efforts of either. (p. xi)

In this chapter I first briefly address Grant's (2003) tenet of "subject knowledge" in order to situate the current study within the literature on the disciplinary nature of history and identify the practices and cultural artifacts emergent bilingual and bilingual students may be expected to encounter in history classrooms. Next, I focus the majority of the literature review on Grant's (2003) tenet of "understanding students," which most directly addresses the research questions guiding the present study. In this section I first examine literature on student perspectives of history (e.g., Epstein, 2009; Peck, 2010) as a means of describing how existing research elucidates the historical perspectives of culturally and linguistically diverse students. I follow this with related analysis and synthesis of literature on particular student characteristics and identity formation among emergent bilinguals (Norton, 2000, 2010; Norton \& McKinney, 2011; Talmy, 2010) in order to provide a foundation for examining factors that may impact how emergent bilingual and bilingual students make sense of U.S. history. In examining literature on students from various bodies of knowledge (i.e., history education, second language acquisition), I seek to enrich the literature review through broadening the focus beyond that of previous studies.

In short, the conceptual framework provides a heuristic for the review of literature that follows and seeks to draw on insights from diverse bodies of knowledge in order to fully address the research questions. In the following sections, I first provide an overview of the literature on the disciplinary nature of history. I then describe literature 
on the teaching and learning of history among emergent bilingual and bilingual students. I next examine the theoretical and empirical scholarship on students' historical perspectives. Finally, in response to the second research question, I analyze and synthesize the extant literature on various student characteristics that may be expected to interact with emergent bilingual and bilingual students' perspectives on U.S. history.

\section{What is History?}

Central to an examination of student perspectives on history is an understanding of the nature of history. In his seminal work on the fundamental question-What is history? - Carr (1961) argued that history "is a continuous process of interaction between the historian and his facts, an unending dialogue between the present and the past" (p. 35). Recent literature in the field of history education has sought to emphasize the "interaction" and "dialogue between the present and the past" through bringing inquiry and historical interpretation into the classroom. In their review of research, Barton and Avery (2016) conclude that the evidence suggests "many beginning and veteran teachers do not understand history as a social construction of the past" (p.36). Yet they contend that what a history teacher believes about the nature of history—-"such as whether it consists of a body of names, events, and dates to be learned, or of interpretations of the past based on evidence and subject to revision" (p. 35) —is the most important knowledge a teacher can have. While recognizing that "critical, disciplinary history has long had an uneasy relationship with what is taught about the past—and how it is taught—in schools" (Seixas, 2009, p. 720), I use this section to describe the current literature on the disciplinary practices of history because an understanding of the constructed nature of 


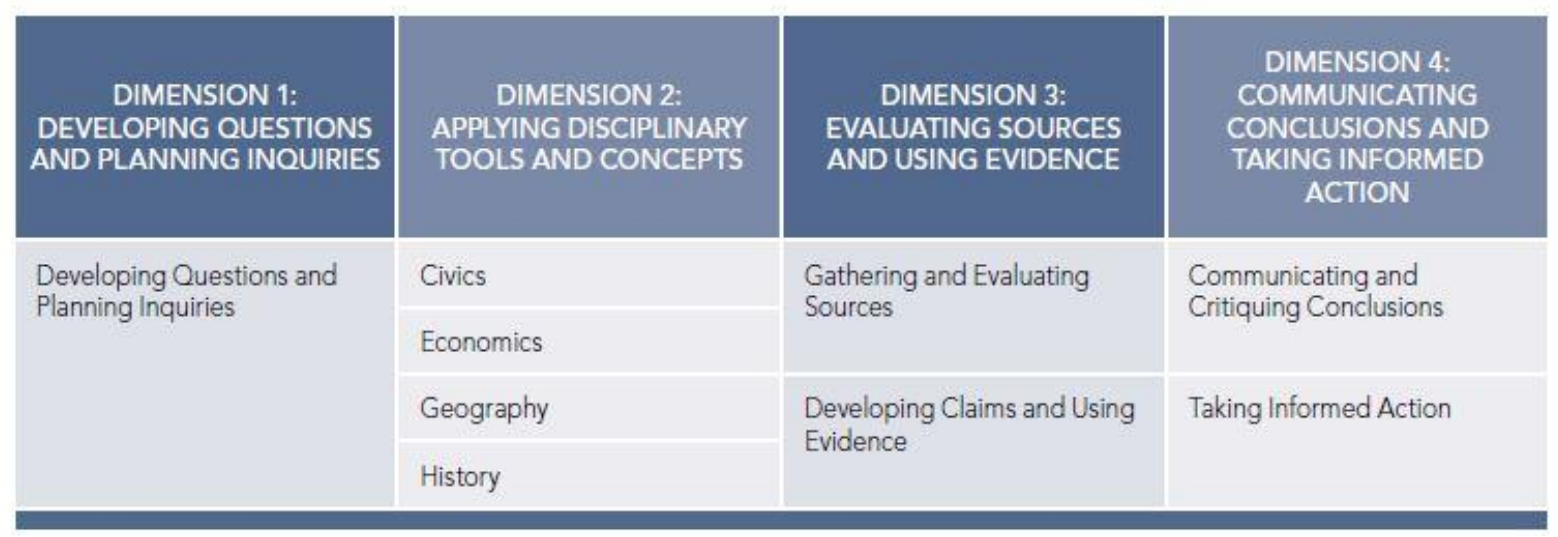

Figure 4. C3 Framework Overview. Reprinted from "The College, Career, and Civic Life (C3) Framework for Social Studies State Standards: Guidance for Enhancing the Rigor of K-12 Civics, Economics, Geography, and History," by the National Council for the Social Studies, 2013, p. 12. Copyright 2013 by the National Council for the Social Studies.

history is fundamental to an examination of how students make sense of history through constructing and de-constructing the narratives they encounter.

I begin the review of the literature by examining the content knowledge of history in order to better understand the fundamental cultural artifacts students encounter in the course of the teaching and learning of history. In the first part of the following section, I examine the literature on the disciplinary practices of history in order to deconstruct the processes that contribute to the formation of students' historical perspectives. In the second part of this section, I examine literature on the narratives of U.S. history as these contribute specifically to students' perspectives on U.S. history.

\section{Disciplinary Practices of History}

The National Council for the Social Studies (2013) published "The College, Career, and Civic Life (C3) Framework for Social Studies State Standards: Guidance for 
Enhancing the Rigor of K-12 Civics, Economics, Geography, and History" as a means of defining and emphasizing an inquiry approach to teaching social studies content. The C3 Framework is explicitly aligned with and intended to build upon the Common Core State Standards for English Language Arts and Literacy in History/Social Studies, Science, and Technical Subjects (Herczog, 2013; NCSS, 2013). In outlining a conceptual understanding of an investigative approach to teaching social studies, the C3 Framework provides a framework based on the "Arc of Inquiry," which is presented in four dimensions (see Figure 4). Dimension 1 represents the first step in which study is guided by the use of "compelling and supporting questions" (p.17). In Dimension 2 the content areas of civics, economics, geography, and history are presented, using the four disciplines outlined in the No Child Left Behind Act of 2001 (Swan \& Griffin, 2013). Dimension 3 articulates the role of sources and the use of evidence, which includes "gathering and evaluating sources" in the process of "developing claims and using evidence” (NCSS, 2013, p.12) in response to the questions developed in Dimension 1. Dimension 4 relates to "communicating conclusions and taking informed action" (p. 12).

Within the history domain, four additional second-order tools or concepts emerge: change continuity, and context; perspectives; historical sources and evidence; and causation and argumentation (see Figure 5). Common historical elements such as chronological sequencing and constructing cause and effect relationships map onto these indicators. The C3 Framework identifies these as themes that can be addressed through historical inquiry, including the assessment of historical sources and the development of historical understanding based on "reasoned interpretation of evidence" (p.45). 


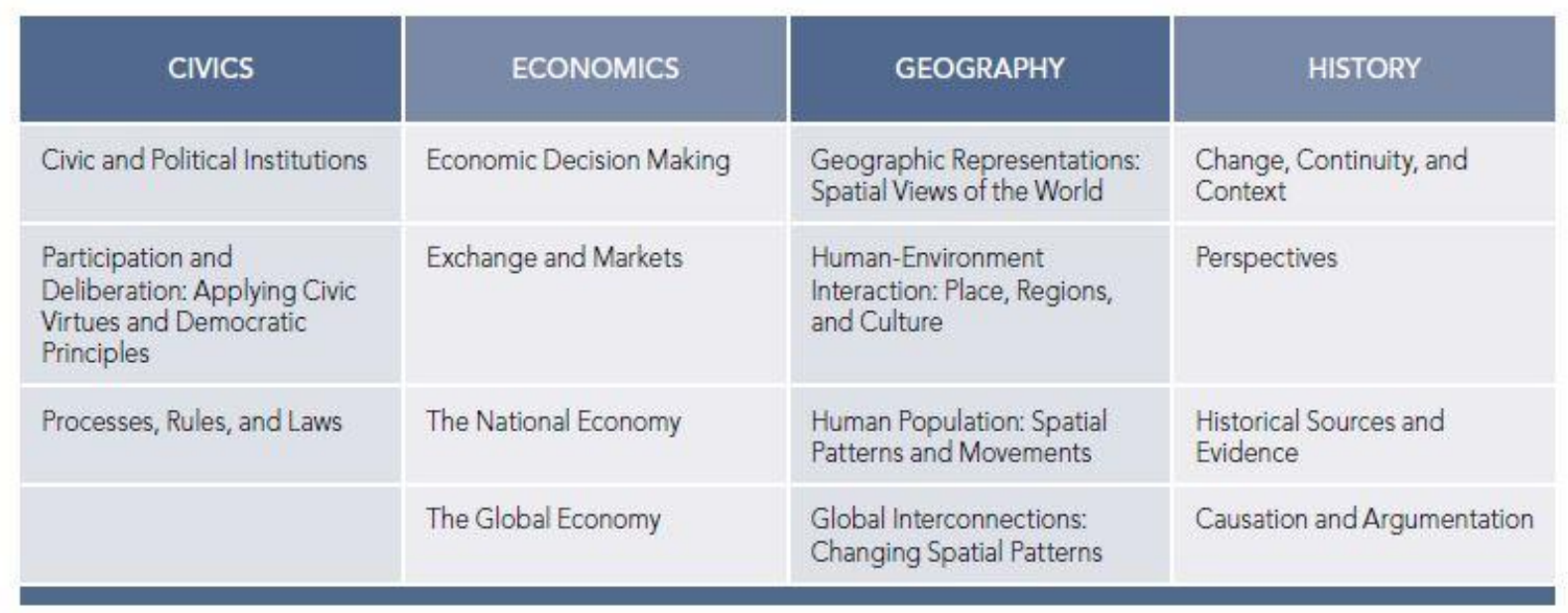

Figure 5. C3 Framework: Applying Disciplinary Tools and Concepts. Reprinted from "The College, Career, and Civic Life (C3) Framework for Social Studies State Standards: Guidance for Enhancing the Rigor of K-12 Civics, Economics, Geography, and History," by the National Council for the Social Studies, 2013, p. 13. Copyright 2013 by the National Council for the Social Studies.

The theoretical and empirical literature on the teaching and learning of history provides support for the inquiry approaches described in the C3 Framework. The disciplinary practices of history include the active processes historians and students of history employ in identifying, analyzing, evaluating, and synthesizing historical evidence for the purposes of inquiry. Such historical inquiry (Barton \& Levstik, 2004) or historical investigation (VanSledright, 2014) requires first-order (e.g., who, what, when) questioning and thinking that result in the "facts" of historical argument. In addition, second-order or disciplinary thinking is needed, activating "a layer of knowledge that lies behind the production of the actual content or substance of history" (P. Lee, 2005, p. 32). These include such essential and broad topics as change over time, accounting for 
Table 1

Assessment Scoring Rubric for Interpreting an Accounts-Based Question

\begin{tabular}{|c|l|}
\hline 1) Establishes/Argues Position & $\begin{array}{l}\text { Clearly stakes out a position on what was thought } \\
\text { (or occurred), argues convincingly, refutes other } \\
\text { possible interpretations }\end{array}$ \\
\hline 2) Citing Evidence & $\begin{array}{l}\text { Refers directly to specific accounts (more than } \\
\text { one); mentions by name (e.g., title, doc. 1, author) }\end{array}$ \\
\hline 3) Corroboration & $\begin{array}{l}\text { Compares/contrasts multiple } \\
\text { accounts/perspectives directly to form } \\
\text { interpretation }\end{array}$ \\
\hline 4) Assessing Account Status & $\begin{array}{l}\text { Direct presence of evaluations of specific } \\
\text { sources' quality/reliability in forming } \\
\text { interpretation }\end{array}$ \\
\hline 5) Contextualization & $\begin{array}{l}\text { Stays within historical context and makes } \\
\text { comments that reflect self-awareness of doing so; } \\
\text { no presentism }\end{array}$ \\
\hline 6) Historical Significance & $\begin{array}{l}\text { Demonstrates understanding of the significance } \\
\text { regarding lasting historical impacts }\end{array}$ \\
\hline
\end{tabular}

Note. Adapted from Assessing Historical Thinking and Understanding: Innovative

Designs for New Standards (pp. 91-92, 104), by B. A. VanSledright, 2014, New York,

NY: Routledge. Copyright 2014 by Taylor \& Francis.

different historical worldviews, and considering historical significance (e.g., Lévesque, 2008; Levstik \& Barton, 2008; Wineburg, 2001).

In order to operationalize such abstract concepts in empirical research, Wineburg (2001) and others (e.g., Barton \& McCully, 2012; Harris, Halvorsen, \& Aponte-Martinez, 2015; VanSledright, 2002) have engaged research participants in various tasks to elicit “historical thinking" in order to observe and analyze students' historical practices. I have organized the discussion of the interpretive "doing" of history (Levstik, 2008) using a similar approach, with VanSledright's (2014) rubric for assessing student essay responses to "compelling questions" (NCSS, 2013, p. 17) providing a comprehensive, succinct framework built around the process of (1) establishing and arguing a position, (2) citing 
evidence, (3) corroborating accounts, (4) assessing account status, (5) contextualizing evidence, and (6) evaluating historical significance (see Table 1).

The first step of historical inquiry or investigation is argument construction based on research questions and an emerging thesis. P. Lee (2005) and others (e.g., Wineburg, Mosborg, \& Porat, 2010) warn against constructing historical arguments that are little more than simplified storylines or historical narratives. As such, researchers in the field of history education stress that a historical narrative cannot be left to stand alone, unsubstantiated or critiqued (Schwebel, 2011; VanSledright, 2008, 2014; Wineburg, 2001). Even so, historical narratives serve as a fundamental cultural tool for hooking the audience and providing a memorable beginning point for historical understanding (Barton \& Levstik, 2004; Grant, 2003; Levstik \& Barton, 2008; VanSledright, 2008). The key to developing a credible argument, as captured in VanSledright's (2014) second indicator, is for students and historians alike to provide evidence from primary sources (e.g., documents, artifacts, ephemera) and secondary sources (Barton \& Levstik, 2010; Seixas \& Morton, 2013; VanSledright, 2002, 2010a).

In the process of building an argument, comparison between and assessment of historical sources - VanSledright's (2014) third and fourth indicators — serve to inform and shape the narrative. While VanSledright identified corroboration and assessing accounts as unique components of effective historical investigation, they should also be understood as parallel or simultaneous processes. In a study in which participants were presented with a variety of primary and secondary sources on the Revolutionary War's Battle of Lexington, Wineburg (2001) reported that historians related texts to prior knowledge and other sources, switching back and forth between gleaning and rejecting 
evidence based on the presentation and perspective of the source. Researchers refer to this key step as evaluating the trustworthiness (Wineburg, 2001) or reliability (VanSledright, 2002, 2014) of the available sources. In summarizing the role of historical investigation, Barton and Levstik (2010) argue that

This process necessarily involves consideration of multiple perspectives, not only so that students understand how the same evidence can lead to divergent interpretations, but also so they recognize that people in the past held different outlooks than we do today and may have perceived events differently than we do. (p.35)

The work with primary sources they describe informs not only the first-order finished product inquiry (e.g., answering the question at hand), but also contributes to a larger understanding of the field of history.

The "different outlooks" that students encounter in historical investigation lead to the fifth indicator of contextualization or "placing events in a proper context" (Reisman \& Wineburg, 2008, p. 202). Contextualization aids historians and students in avoiding presentism (Brophy \& Alleman, 2008), which refers to judging the past according to the standards and social norms of the present (Seixas \& Morton, 2013). Though "teaching about the past always and unavoidably implicates the present" (Schweber, 2010, p. 155), VanSledright (2002) stressed the importance of historical contextualization, concluding that "avoiding presentism entails understanding the assumptions, convictions, and philosophies of historical actors within their historical milieu" (p.146). Barton and Levstik (2004) and others (e.g., Brooks, 2011; Goldberg, 2013; Lévesque, 2008) have also highlighted the role of empathy in combating “children's predispositions toward presentism” (Brophy \& Alleman, 2008, p. 42). 
The final category of historical significance is actually addressed first - either implicitly or explicitly_in most classrooms and publications by making a case for why a person, event or other topic of inquiry should be investigated. In research on historical thinking participants are often asked to identify people or events that are "famous" (e.g., Wineburg \& Monte-Sano, 2008a) or “important” (e.g., Epstein, 1998), prompting an assessment of historical significance. Among the various models and criteria for establishing historical significance presented in the literature, the common threads include people and events that sparked momentous change, relate to broader concepts, or remain relevant in the present (Bradshaw, 2006; Cercadillo, 2006; Counsell, 2004; Dawson, 2003; Seixas \& Morton, 2013; VanSledright, 2014).

While empirical research has been instrumental in understanding the disciplinary practices of history and contributing to the formation of the C3 Framework (NCSS, 2013) and similar standards documents, Barton and Levstik (2010) and other researchers (e.g., Grant, 2003; Loewen, 1995; Loewen, 2010) have found that common instructional practice in history classrooms looks very different from the "doing" of history described above. For example, in analyzing Status of the Social Studies survey results, Thieman and colleagues (2013) found that while "middle and high school teachers reported that their students examine primary sources and complete writing assignments...the national and state data also indicate that secondary teachers relied on lectures and also reported using textbook-based worksheets" (p. 59). Among survey respondents who taught in Virginia $(N=500)$ "listening to lecture" was reported as the most prevalent instructional strategy with $65 \%$ of teachers indicating they used it "at least weekly" (p. 51). Even so, an understanding of the disciplinary nature of history is necessary for teachers and 
researchers to unearth the processes by which emergent bilingual and bilingual students make sense of the history they encounter in the classroom, whether this process includes lecture, textbook, or analyzing photographs and other primary sources. As Epstein (2009) and others (e.g., Peck, 2010) have found, many students from diverse cultural and linguistic backgrounds do examine and critique the history they encounter in school. Insights into the steps involved in "historical thinking" are needed precisely because they “create an opportunity to include multiple perspectives and/or challenge traditional metanarratives" (Salinas, Blevins, \& Sullivan, 2012, p. 19). In the following section, I examine the research on the "traditional metanarratives" commonly presented in U.S. history curriculum and instruction.

\section{Narratives of U.S. History}

From a sociocultural perspective, students' linguistic and cultural positionality are important characteristics that mediate their historical perspectives. In their review of the knowledge base on the teaching and learning of history, Barton and Avery (2016) identify the study of student perspectives on history across sociocultural differences as a significant area of recent and forthcoming study. In the following section I review the literature on the various student perspectives on history that have emerged in the research. In the process, I first provide an overview of the national narratives and depictions of immigrants from the research on the U.S. history taught in schools. I then provide an in depth review of the historical perspectives of students from different cultural and linguistic backgrounds.

The narrative of U.S. history found in schools has traditionally been one of progress and nation building. Studies of history textbooks (e.g., Alridge, 2006; Hilburn 
\& Fitchett, 2012; Loewen, 1995; Loewen, 2010; Suh, An, \& Forest, 2015), history standards (e.g., C. B. Anderson \& Metzger, 2011; Journell, 2008, 2009; Shear, Knowles, Soden, \& Castro, 2015; Vasquez Heilig, Brown, \& Brown, 2012), and history instruction (e.g., Barton, 2001; Barton \& Levstik, 2004; Grant, 2003; VanSledright, 2008) have documented that the U.S. history taught in schools presents a Eurocentric narrative that glosses over persistent inequality and provides students with few opportunities for inquiry. Such an approach is intended to "foster social cohesion and national identity" (Carretero \& van Alphen, 2014) through defining the "imagined community" (B. Anderson, 1991) that the United States of America represents. Barton and colleagues' (Barton, 2012; Barton \& Levstik, 2004; Barton \& McCully, 2010) research highlights the role of identification in learning history, reporting that many U.S. students do indeed identify with U.S. history, reading themselves into the national narrative as evidenced by students" use of the terms "we" and "us" when talking about U.S. history (see also Epstein, 2000). While such identification can serve as a powerful motivating force to learn about U.S. history, Levstik and Barton (2008) also described a downside of the oversimplified, longstanding narrative: "The traditional story, focusing on national politics, elite society, and traditional heroes, had been elegant, linear and unconfusing precisely because it left out so much" (p. 100). The task of the present study included investigating how students from culturally and linguistically diverse backgrounds might make meaning of national U.S. history that traditionally focuses on "powerful men with an emphasis on political nation-building, economic growth and military conquest" (VanSledright, 2008, p. 24). As the portrayal of immigrants within this narrative may be of particular interest considering the lived experiences of students and their families, I 
turn now to examining recent research on the depiction of immigrants in U.S. history classrooms.

Recent textbook analysis suggests that the U.S. history curriculum largely overlooks immigrants, minimizing immigrant contributions through fitting immigrant stories within the existing progress-oriented narrative. In a study of North Carolina history curriculum, Hilburn and Fitchett (2012) conducted a content analysis of 25 eighth grade history textbooks. The textbooks ranged in publication dates from 1911 to 2009 . The researchers identified the context of a "new gateway state" with a growing number of immigrants as the impetus for their study, finding that few of the textbooks explicitly defined immigrants or immigration. They noted an overall focus on immigrants as the "founders" of North Carolina with few contemporary examples (see also Journell, 2009). Hilburn and Fitchett concluded that when immigration was addressed, the textbooks provided a "focus on immigrant contributions to capitalism at the expense of their sociocultural contributions" (p. 57). In a similar textbook study, Suh, An and Forest (2015) analyzed the content of four middle school and four high school U.S. history textbooks used in Virginia. They found that Asian Americans were portrayed as having faced discrimination in the past and having subsequently achieved equality and success. They argued that such a depiction aligns with the broader narrative of progress- toward racial equality in this case- but also limits the historical agency of Asian Americans by subsuming them within the broader narrative. The two studies provided similar findings related to the limited and limiting portrayal of immigrants: in each study, textbooks largely overlooked the presence and contributions of Asian Americans and immigrants, respectively, fitting them within the existing progress-oriented national narrative when 
they were included. Given these various narratives found within the U.S. history curriculum, research suggests that students make sense of U.S. history in unique ways. In order to build on the theoretical and curricular descriptions of U.S. history presented in this section, I examine the research on students' historical perspectives in the following section.

\section{Student Perspectives on History}

As Grant (2003) argued, an understanding of students is fundamental to ambitious teaching and learning, particularly in conceptualizing how the teaching and learning of history can more fully address student needs. Understanding the perspectives of emergent bilingual and bilingual students is fundamental to the present study as the research questions examine students' historical perspectives. In this section I examine the extant literature on student perspectives on U.S. history in order to conceptualize how students make sense of U.S. history. In short, the findings reveal that students who feel marginalized or excluded from the curriculum often reframe or distrust school history. In particular, race and ethnicity, gender, national origin, and religious backgrounds serve to mediate students' perspectives on the national history they encounter in the classroom (Barton \& Avery, 2016). In this section I examine the extant literature on race and ethnicity, national origin, religious background, and gender to identify characteristics that may be expected to mediate students' historical perspectives.

\section{In Black and White: Comparing Student Perspectives by Race}

A sociocultural approach on the teaching and learning of history foregrounds the role of students' positionality and sense making in the course of history instruction. In addition, while classroom activities are understood to be important in the development of 
historical thought and understanding, Wineburg and colleagues (Wineburg, 2000, 2001; Wineburg \& Monte-Sano, 2008a) highlighted the role of media, family and other sources of cultural knowledge as also being influential, noting that "the calculus classroom may be the site where we learn advanced mathematics, but we learn history everywhereschool hardly possesses a monopoly" (Wineburg, 2000, p. 323). Research in elementary (VanSledright, 2002), middle (Levstik \& Barton, 2008), and high school (Wineburg, 2001) settings suggests that students of all ages have difficulty understanding the contested or constructed nature of historical accounts. Research also shows that many students and teachers alike internalize the singular American identity linked to the narrative of U.S. history described above (Barton \& Levstik, 2004; Levstik \& Barton, 2008; VanSledright, 2008). However, a growing body of knowledge also demonstrates that some students, particularly those of certain racial and ethnic backgrounds, resist this narrative and the American identity it portrays.

Research indicates that students from culturally diverse backgrounds resist or reframe U.S. history in response to the marginalization of certain groups in the traditional curriculum based on race (i.e., African Americans) or ethnicity (i.e., Latinos). Few studies have directly investigated the perspectives of emergent bilinguals or other students from immigrant families. However, a growing body of research does explore how student race and ethnicity might be understood to impact historical thinking.

In one such line of research, Epstein $(1998,2000,2001,2009)$ analyzed the meaning making of African American and European American students of various ages through questionnaires, interviews and focus groups. In her study of 49 students in the eleventh grade U.S. history classroom of an experienced African American teacher in an 
urban Midwest school, Epstein (1998) found that when asked to nominate the top three figures from U.S. history, most Black students emphasized race, naming Martin Luther King Jr. and identifying him as someone they "admired" because of his work for the “Black race” (p. 404). Overall, "African American historical figures constituted 75\% of the African American students' selections; European American figures constituted 82\% of the European-American students' selections"' (p. 403-404).

Epstein (1998) also asked students to rank secondary historical sources according to credibility. Thirty-four percent of the nineteen Black students in the study identified their family as their first or second choice, followed by teacher $(21 \%)$ and "TV, movies, or video" (21\%). Among White students, the textbook was the most highly ranked (38\%), followed by the teacher $(32 \%)$ and books (18\%). These results demonstrate a clear divergence in the historical sense making of students of different cultural and racial backgrounds. This is manifested not only in the identification of different historical figures as important, but also in the sources of historical knowledge that students identified as trustworthy. While White students said that textbooks and teachers were credible "because textbook authors were experts on history and teachers had studied history and received college degrees" (p. 408), Black students reported finding family members as more trustworthy.

Based on detailed analysis of interviews with five White and five Black eleventh grade students, Epstein (2000) identified various overarching perspectives on U.S. history, including a "traditional Eurocentric perspective," which Andrea (a White female) voiced when beginning her narrative of U.S. history with European Exploration: "If they never discovered it, we'd never be here" (p. 193). Ellen (also a White female) 
demonstrated a "revisionist Eurocentric perspective" that critiqued cruel and racist treatment of Native Americans, African Americans and Japanese Americans, yet stayed within the larger progress-oriented narrative: "Like I said before, people went out and changed things and got their rights" (p. 196). Maya (a Black female) articulated an "Afrocentric perspective" when she began her U.S. history timeline with "Black people and slavery" while explicitly critiquing an approach "that always starts with White people first" (p. 199). Finally, Tyrone (a Black male) provided a "double historical consciousness perspective" in bridging multiple views and highlighting the role of historical actors of various backgrounds. Epstein concluded that the perspectives of the Black students emphasized White racism, resisting the themes of equal rights and democratic polity that pervade both the official narrative and the traditional perspectives that White students demonstrated.

In further study, Epstein $(2001,2009)$ examined the views of Black and White students in fifth, eighth, and eleventh grade. Epstein reported that even the younger students who were in fifth grade discussed race-related topics through different lenses. For example, White students omitted the role of White slave owners, stating that "Black people were slaves" or "Black people worked for other people" (Epstein, 2001, p. 43). By contrast, Black students defined slavery as "Black people worked for White people" or "White people beat Black people and treated them mean" (p. 43). As in Epstein's previous studies, Black students identified Martin Luther King, Jr. and Rosa Parks as key figures because they "encouraged Black people to stand up for themselves" (p. 43). White students, however, “...framed slavery and the Civil Rights Movement as a problem of fulfilling the nation's principles of equality, rather than as a problem of the 
ongoing legacy of racism" (Epstein, 2009, p. 54). Overall, however, Epstein (2001) found that while the fifth grade students demonstrated an awareness of race, older students "constructed much more substantive explanations of historical actors and events" (p. 44). Epstein's empirical work comparing the views of U.S. history espoused by Black and White students provides a backdrop against which the limited research on how students of color from other ethnic backgrounds make meaning of U.S. history.

\section{Beyond Black and White: Latina/o Student Perspectives}

While Epstein's series of studies among Black and White students consistently demonstrated that students' race mediates their historical perspectives, recent research into Latina/o and Asian American students' perspectives on U.S. history suggests that educational attainment, immigrant experience and other student characteristics also serve to mediate students' meaning making. Within this mix the few studies that investigate the meaning making of immigrant students and those studies that compare within group differences provide particularly helpful insights when considering how emergent bilinguals may make meaning of U.S. history. In this section, I examine studies that investigate the views of students from a range of ethnic backgrounds. I first analyze divergent findings from studies among Latina/o and Asian American students. I then present research on the unique positionality and perspectives of immigrant students. Finally, I conclude with findings from those few studies based upon group analysis.

Research into the historical perspectives of Latina/o students from different geographic areas and among different groups of Latina/o students has yielded divergent results. In a study in which student views aligned closely with those of the African American students in Epstein's research, Almarza (2001) studied 18 Mexican American 
students in an eighth grade U.S. history class in the Midwest. The students demonstrated open resistance to the portrayal of U.S. history, as captured in Daniel's comment:

She [the teacher] should teach about our past and about our culture...it's okay that 'gtieros' [Whites] learn their history because they need to know their roots...but she only teaches about her past and her culture... she only talks about the American stuff. (p. 4)

Almarza concluded that Mrs. Perryman's choice to "stress the 'official' version of the participation of White people in the evolution of American history" (p. 11), including during lessons on the Alamo and other historical interactions between White and Mexican American historical figures, contributed to the feelings of exclusion the students reported. Busey (2013) also studied the perspectives of eighth grade Latina/o students. The participants in his study identified ancestral roots in five different Latin American countries and attended a middle school in the Southeastern United States. Javier, who identified as Dominican and Puerto Rican, captured the participants' collective sentiment when he stated: "In history we learn about the same races, either African Americans or White. I would like to learn more about our race, like Latinos" (Busey, 2013, p. 99). In these two studies, Almarza and Busey documented middle school Latina/o students who clearly separated themselves from the narratives of U.S. history they encountered in school. When they used the pronouns "we" and "our" they referred not to "American" history, but a desire to learn about Latina/os. Research among other groups of Latina/o students, however, reveals different perspectives.

Two other studies among different groups of Latina/o students highlight the diversity within broad categories and the role of student experiences and characteristics on students' perspectives on U.S. history. In a study of 70 AP U.S. history students in a South Florida high school, Terzian and Yeager (2007) found that their participants of 
mostly Cuban American background espoused a traditional narrative of U.S. history as one of rights and progress. For example, when asked to identify the most important people in U.S. history, students nominated George Washington and Abraham Lincoln as their top picks. Terzian and Yeager noted that among these students - most of whom were from immigrant families_- "no one called for the inclusion of more Latino or Cuban history, with the possible exception of the Cuban Missile Crisis and the Bay of Pigs invasion" (p. 68). Terzian and Yeager concluded that while the students in their study identified their families as important influences on their perspectives on history—much as African American students in Epstein's studies had—-the Cuban American students' perspectives on U.S. history were most similar to those of the students of European descent that Epstein investigated. Terzian and Yeager suggested that the higher educational levels and likelihood of identifying as "White" prevalent within the Cuban American community may help explain the difference in views expressed among their Latina/o participants as compared to the perspectives described by other Latina/o students and other students of color in previous research. While Terzian and Yeager did not explicitly address how the fact that their participants were in an AP class might have impacted their historical reasoning, this marker of educational achievement certainly aligns with the broader notions of educational success that Terzian and Yeager did name. In addition, the unique historical realities of the Cuban American community, including the families' reasons for immigrating to the U.S. initially, may help explain why the Latina/o students in Terzian and Yeager's study articulated a view of American "exceptionalism" (p. 74) rather than the oppressive stance voiced by students in Almarza (2001) and Busey's (2013) studies. 
Similarly, Dan and colleagues (2010) surveyed 75 eighth grade and 27 eleventh grade students from West Texas, finding that their 54 "Hispanic American" participants provided responses similar to those of the study's 39 White participants. For example, both White and Latina/o students identified history teachers and textbooks as the two most credible sources of historical information. With the exception of César Chávez, Latina/o students also nominated many of the same historical figures in U.S. history as White students. Dan and colleagues suggested that one reason for this may have been that "few Hispanic-American heroes and activities were mentioned in textbooks" (p. 335). The authors concluded that students of "each ethnicity tended to select people and events that related to their group experiences" (p. 334), a finding that aligned with the views of Almarza (2001) and Busey's (2013) participants. Yet the limited data on the students in Dan and colleagues' study—specifically whether students were immigrants and to which countries they traced their heritage_-limits broader comparison with the Latina/o students in the other studies. Even so, these four studies collectively demonstrate that different views can be found among Latina/o students, highlighting the fact that terms such as Latino and Hispanic do not refer to a homogeneous ethnic group (see, for example, González \& Gándara, 2005; Irizarry, 2007; Kena et al., 2014; Tatum, 2003; Umaña-Taylor, 2009). Studies that provide similar comparative analysis provide additional insights into how the experience of immigration may also impact how students make sense of U.S. history. In the following section, I examine research on the immigrant status of students and how their lived experiences interact with their historical perspectives. 


\section{Immigrant Experience and Perspectives on National History}

While there is little research that investigates the historical perspectives of immigrant students, a few studies suggest that living in a new country for only a short time may impact how students' make sense of the history they encounter in school. In a study of Korean American high school students, An (2009) compared the views of "early study abroad" students who had been educated in South Korean schools to those of students who were born to South Korean immigrants living in the United States. An found that students' sense of identity and belonging reflected their lived experience as those students who had been educated in South Korea demonstrated a traditional nationbuilding narrative through naming U.S. presidents as key figures. In contrast, "many American-Korean youth emphasized [that Martin Luther] King [Jr.] worked 'not just for Black people but for all the non-White people"” (p. 776). Yet, across the various groups, all the Korean American students in the study equated being "American" with "White people" (An, 2009, 2012). An's analysis suggests that while there were commonalities among the views of her South Korean participants, the experiences of the immigrant students in her study contributed to more traditional views of U.S. history, a finding An attributed in part to the nation-building narrative taught in South Korean schools.

In another study among South Korean immigrant students, Choi and colleagues (2011) recruited 43 middle and high school students from five research sites across the United States, most of whom had moved to the U.S. within the five years preceding the study. Based on mixed method analysis of student surveys and interviews, Choi and colleagues presented three findings:

(1) Lack of English proficiency, background knowledge, and "American patriotism" presented barriers; (2) White, American-centered perspectives in the 
curriculum led students to feel their own country of origin was marginalized; and

(3) Teachers' perceived lack of care and disengaging pedagogies. (p. 1)

The authors concluded that "approximately $90 \%$ of Korean immigrant students interviewed (40 of 43) expressed in part a negative perception and experience of learning social studies, especially US history" (Choi et al., 2011, p. 6). While Choi and colleagues' findings that South Korean immigrant students described U.S. history as a Eurocentric narrative align with An's $(2009,2012)$ findings, the participants' identification of classroom practices and language as mediating factors emerged as new findings. Yuhee, a 14-year-old girl from a city in the Southeast, reflected on a representative incident as an example of how classroom events might shape immigrant student perspectives:

Once we had a group discussion. I had no idea what we were supposed to do. Then a girl in my group talked to other group members that I could not participate because I could not speak English. Then, another boy opposed, saying "she can understand so we should discuss all together"...I was so embarrassed. I was just waiting for the period to end. (p. 8)

In this case, one of Yuhee's classmates named language use as a barrier. While a peer ultimately intervened on her behalf, Yuhee reported that her motivation to engage in the group discussion had been squelched as she was "so embarrassed" by the incident. Being an immigrant and an emergent bilingual—a term Choi and colleagues do not use-were presented as limitations.

In another example of differences between An $(2009,2012)$ and Choi et al.'s (2011) analysis of Korean immigrant students, Choi and colleagues presented an excerpt from their interview with Seunghwan, a 17-year-old from a suburban school in the Northeast, in which he recalled his experience. Whereas the Korean-educated immigrant students in An's study provided a more traditional narrative of U.S. history, Seunghwan 
demonstrated an enhanced analytical framework based on his experiences of learning history in two contexts:

US history is biased by American perspectives a lot. When we learned about the Mexican War, it simply concludes that "Yes, we were wrong back then." And that is it! Sometimes, history textbook describes the war favorably. As an immigrant, I am trying to be very careful about those perspectives... Once we learned about Japanese colonial control over Korea. Then, the textbook describes that Japan took over Korea, and it brought peace and better consequences to America. As an Asian, I was like "How dare you!" Even though I have lived here for a long time, I mean, as a Korean, this is so not true. (p. 9)

Seunghwan demonstrated the power of comparative analysis, cross-referencing the portrayal of events in the U.S. history curriculum with his prior knowledge from living and attending school in South Korea. In the process, he clearly read his own experiences and status as "an immigrant," "an Asian," and "a Korean" into his analysis of the U.S. history and history textbooks. Paula, a Brazilian immigrant in Martell's (2013) eleventh grade U.S. history class, voiced a similar understanding of how her own experiences impacted her perspectives on U.S. history: "I am from a different country, a different culture, and different past, history past, than you too, so if something happens, we are going to look at it differently" (p. 75). These examples demonstrate the variety of sociocultural factors that inform student meaning making in the teaching and learning of U.S. history. Together these studies highlight the potential of within group analysis, as length of time in the United States and language proficiency emerge as themes through this analysis. In the related study I examine next, the theme of cross-group peer interaction surfaces as an additional mediating tool in student meaning making of national history.

In a qualitative focus group study that included participants of a variety of ethnic backgrounds, Peck (2010) studied the ascription of historical significance within 
Canadian history among grade 12 students. The participants came from three secondary schools in British Columbia and included 17 students born in Canada, seven immigrants and two Aboriginal students. Peck described how student responses mapped onto three narratives of Canadian national history. The "Founding of the Nation" narrative was most prevalent among students of European descent. While the "Diverse and Harmonious Canada" narrative was also espoused by some of the White Canadian students, a few of the immigrant students also reflected this approach through their focus on Canada as a multicultural society. Peck reported on the deliberation process of one focus group that was made up of four immigrant students. In their discussion, Teresa, who had lived in Canada for 14 years, suggested that the group construct their timeline based on a "multicultural" Canada such that their events would "generally apply to the history of Canada, not necessarily a specific background or ethnic group" (p. 603). In reporting the group's continued deliberation, Peck argued that

Vincent and Mark, who had lived in Canada 13 and eight years, respectively, agree with [a multicultural] stance. Length of time in Canada may have been a determining factor in this group's selection process, as Sam had spent limited time in Canada, at least compared to his group-mates. He was particularly drawn to issues related to minority rights. (p. 603)

Peck concluded that Sam, an Eastern Chinese student who had "most recently" immigrated to Canada, reflected the third and final "Diverse but Conflicted Canada" narrative. Much as Seunghwan had in Choi and colleagues' (2011) study, Sam drew on his own experiences and self-described positionality in a new society in articulating his view of Canadian history:

We should think about the present and then consider what event has contributed to the present and those events should have the biggest impact because we are still feeling that impact, right? So of all of these, I think minority rights shouldn't be excluded, since we already have multiculturalism [on the timeline] — that's 
actually a solution to that issue. We have a solution, but we don't have the issue. (p. 604)

Sam specified the role of "the present" in his ascription of historical significance. He further elucidated the role of length of time in a new country by stating, "I still [emphasis added] feel my pride as a Chinese...But here it comes - a question: What is Canadian culture? I think it is multiculturalism. So as I become more Canadian, I am more and more tolerant to other cultures" (p. 605). In this excerpt Sam appears to suggest that he understands he is in a process of transition, with his own views becoming more like those of his immigrant peers who have lived in Canada longer and who focus on multiculturalism as a means of creating common ground among students of various ethnic backgrounds. In summary, as immigrant students from China, Russia, Vietnam and the Philippines sat together and discussed how to choose ten events from Canadian history, the common denominator of a "multicultural" Canada became the shared theme. Sam clearly states that the question of "What is Canadian culture?" drives this deliberation, with his own "in between" status as the newcomer in the group leading him to favor more specific minority rights events, whereas those students who had spent more time in Canada lean toward a more "harmonious" narrative of a multicultural Canada. This vignette provides an example of how discussion among immigrants of various backgrounds and lengths of stay in the host country can mediate student meaning making, as Sam clearly voiced how his own positionality as a relative newcomer led to his more critical view of Canadian history, even as the groups' discussion and final timeline reflected a more moderate or mainstream interpretation.

In summary, the experiences of students of various racial, ethnic, and immigration backgrounds clearly lead to different views and perspectives on U.S. and Canadian 
national history. In cases in which students have encountered history content related their ethnic heritage, researchers report increased student interest and suggest that students draw on their historical knowledge beyond the official curriculum in productive ways (Harris et al., 2015; Levy, 2014; Ramirez, 2012). However, the research described above illustrates that these occasions are few and far between, with Black (1998, 2000, 2001, 2009), Latina/o (Almarza, 2001; Busey, 2013; Dan et al., 2010; Terzian \& Yeager, 2007) and Asian American (An, 2009, 2012; Choi et al., 2011) students consistently reporting that the U.S. history they encounter in school is Eurocentric. Yet there is less agreement among students in these studies regarding how to respond to this history or the national narrative in which it is presented. A consistent finding is that the experience of immigrant students mediates their meaning making of national history, as students bridge the narratives of their country of origin and their new home (An, 2009; Choi et al., 2011; Peck, 2010). Another key finding is that few studies have directly investigated how emergent bilingual status or English language proficiency may impact students' perspectives on U.S. history. While Choi and colleagues (2011) explicitly address the role of language in their study, most others do not, with Busey (2013) explicitly recruiting bilingual Latina/os and Peck (2010) setting a prior knowledge requirement that served to exclude potential emergent bilingual participants. Finally, the studies described in this section represent a common methodological approach, with most representing qualitative case studies in school settings.

In the following section, I examine the literature on how religion - another student characteristic — interacts with the ways in which students make sense of history. In considering the role of student religious backgrounds I draw on research from both in 
and beyond the U.S. context in order to best utilize the available body of knowledge. In short, the evidence suggests that religious background serves to mediate student perspectives on school history in ways that are similar to the mediating effects of race and ethnicity.

\section{Religious Background and Historical Perspectives}

In their review of the research, Barton and Avery (2016) identify student religious background as a significant mediating factor in how students make sense of history. Barton and Avery acknowledge that the distinction between various student characteristics can be difficult to assess, particularly noting the overlap between religion and ethnicity, as in the case of Arab Israelis and Jewish Israelis, as well as the link between religion and political ideology. As such, in this section I have chosen to highlight a somewhat limited body of knowledge in which religious background has been a primary focus of the research, conceptualizing this examination as complementary to the above sections on the often related factors of race and ethnicity.

In short, students who identify closely with a particular religious background often affiliate with historical narratives that align with the viewpoints and perceived interests of their faith community, rejecting counter-narratives that conflict with these viewpoints or interests. In an interview study conducted with 64 Jewish-Israeli twelfthgrade students, Goldberg (2013) framed his analysis of student discussion on historical Israeli immigration policy around students' ethnic identity as Mizrahi-Oriental or Ashkenazi-European Jews. Even as Goldberg specified that the comparison investigated the impact of "Jewish ethnicities" on students' historical thinking, the study clearly demonstrates the inter-relatedness of ethnicity and religious background as most of the 
Mizrahi families came from "low-income, politically and religious conservative" families whose "parents or grandparents immigrated to Israel from Muslim countries during the mass immigration of the 1950s" (p. 40). Goldberg concluded that in the few instances in which students demonstrated evidence of evaluating the historical sources on which they based their arguments, "evaluation tended to reflect learners' identity needs" (p. 46). Raya, a granddaughter of Iraqi immigrants, provides an example of this as she pieced together quotes from various sources in making her argument, concluding that Ashkenazi leaders "feared the religious block [would] want a theocracy" (p. 46). Through this example of what Goldberg terms "anti-religious political motivation," Raya exemplifies the link between religious background and ethnic identity as depicted in Goldberg's study of Israeli students (see also Porat, 2004).

Barton and McCully's $(2005,2010)$ research among secondary students in Northern Ireland reveals similar patterns in how religious background interacts with students' historical perspectives. Based on interviews with 253 students, Barton and McCully concluded that students' perspectives on national history were mediated in part by the strong link between Catholic or Protestant religious identity and the related political leanings toward Nationalism or Unionism, respectively. In the interviews, the participants (ages 11 to 14 ) worked in pairs to sort 28 images into groups and then explained their selections. In response to the question, "Which of these pictures has the most to do with you, or who are you?" (Barton \& McCully, 2005, p. 96), "students most often justified their choices by explaining how the pictures related to their national or religious communities" (p. 98). Barton and McCully cited examples, such as "He's a Catholic, just like I am” (p. 98). Barton and McCully also found that student responses 
varied across grade level, gender, geographic region, and type of school. In Barton and McCully and Goldberg's (2013) studies, the evidence suggests that religious background interacts closely with other identity characteristics - particularly political identity and ethnicity, respectively - in the process of making sense of history.

In order to conceptualize how religious background may serve not only as an identity marker, but also as an epistemological mediator, I also examined research beyond the literature on student perspectives on history. Research on the teaching and learning of history, for example, suggests that in some cases religion is cited as the reason for the way in which history is taught, such as in the case of highly prevalent confessional or religious schools in Lebanon (Yoder, 2015) or the teaching of the Holocaust (Schweber, 2006a) or 9/11 in U.S. Christian schools (Schweber, 2006b). At the classroom level, Hess and McAvoy (2015) investigated the case of Mr. Walters who they described as providing "bounded autonomy" for his twelfth grade government students at a Midwestern Christian school. In her discussion of the tension between democratic principles and "theological certainty," James (2010) concluded that students may use religious identity to determine how to engage in classroom activities. In a representative example, Jackie, a student in James' elementary social studies methods course asserted, "I am not going to participate in this discussion. My faith in God means that, for me, there is one right answer to the question you're asking" (James, 2010, p. 619).

The research on how religious background may impact how K-12 students make sense of history is limited. However, a few studies suggest that students do engage in what Gottlieb and Wineburg (2012) termed "epistemic switching” in which a historianor student—varies "epistemological criteria to align with the allegiances triggered by the 
[historical] document under review" (p. 84). For example, in a study of an eighth grade unit on the Holocaust in a Midwestern English language arts class, Spector (2007) found that religion clearly framed the student discourse around the reading of Elie Weisel's Night. Spector concluded that "Christian students - and only Christian students — read the Holocaust in ways that set it up as a spiritual battle between forces of light and forces of darkness" (p. 30). Spector's findings align with Schweber and Irwin's (2003) earlier research in which Christian students similarly used religious language to discuss the Holocaust, explaining that they believed God protected the Jews because their Christian beliefs included viewing the Jews as God's "chosen" people. In total, the literature demonstrates that student religious background does mediate the development of students' historical perspectives, at times reflecting students' identity much as ethnicity might, and in other situations influencing students' assumptions and values. In the next section, I examine the literature on the role of gender in how students make sense of history.

\section{Gender and Historical Perspectives}

In general, while the research on the interaction between gender and student perspectives on school history is limited, the evidence suggests that gender serves to mediate students' historical perspectives. For example, in reviews of literature Crocco (2008) and Barton and Avery (2016) argue that the primary finding on the role of gender in students' understanding of history — and social studies more broadly — is that the available research is lacking. Crocco concluded that research on the role of gender could be "encountered only rarely" (p. 173), leading her to echo a previous (2001) call for more 
research. In this section I examine what limited research is available on the link between gender and students' historical perspectives.

While the literature on how student gender impacts perspective-taking is sparse, research clearly documents the ways in which gender is commonly represented in the history curriculum. In a telling example, the index for Loewen's (1995) seminal Lies My Teaching Told Me contains an entry for "omission of women's history" (p. 383). When Loewen cited earlier research suggesting girls did not like history or social studies at the rates boys did, he argued that the disproportional representation of male historical figures in school history accounted for the difference in students' general affinity levels. In more recent research on the portrayal of gender in U.S. history textbooks (Chick, 2006; Schocker \& Woyshner, 2013), trade books recommended for use in social studies classrooms (Chick \& Corle, 2012), and state social studies standards (Crocco, 2007), the shared findings reflect a continued “omission of women's history” (Loewen, 1995). For example, Schmeichel (2015) analyzed 16 published lesson plans focused on women to identify what rationale is commonly provided for highlighting or including women in the social studies curriculum. She found that half of the lessons cited disciplinary goals (e.g., perspective taking, primary source analysis), while five explicitly sought to provide additional "attention to women in the curriculum" and one attempted to "work toward gender equity" (p. 8). Schmeichel concluded that social studies needs a stronger focus on critical feminist approaches in order to bring transformative curricular change (see also Hahn, Bernard-Powers, Crocco, \& Woyshner, 2007).

In the available studies in which student gender and perspectives on history are explicitly addressed, the research suggests that both female and male students reflect the 
gendered perspectives of their social contexts. For example, in a study of an eighth grade instructional unit on women's involvement in nineteenth-century U.S. reform movements, Levstik and Groth (2002) found that while students actively argued for the inclusion of women in the curriculum, they also voiced concerns over "reverse sexism" when the unit included primarily female historical figures. Levstik and Groth noted that the mostly female participants (41 of 50 students) at the arts-focused magnet school created a unique school setting, yet their evidence suggests that even in this femaledominated setting the "male-stream curriculum" (p. 249) influenced student perspectives. For example, Arlene argued that the unit the class was studying would have had more credibility if it incorporated more of a "male perspective" (p. 244) and other girls expressed a concern that the class might be considered "against men" because of the focus on women (p. 245). In a study of twelfth grade students' analysis of images of women in history, Colley (2015) similarly found that students discussed a power imbalance between men and women. For example, Jenna described men as acting "superior" to women in the past and Skylar alluded to gender roles in explaining that men could expect to have "multiple options" for employment (p. 133). Colley also reported that the female participants in her study discussed what it meant to be "like a girl" in different contexts (i.e., throwing a ball "like a girl") as they discussed the photographs. Colley concluded that these student interactions "stirred up emotional conversations over their own experiences with sexism, bullying, or judgment based off of their appearance" (p. 134). As in Levstik and Groth's (2002) study, Colley's participants demonstrated a complex interaction between student gender and interpretation of historical narratives and images. 
Barton and colleagues (Barton, 2005; Barton \& McCully, 2005) studied students' historical perspectives in Northern Ireland and similarly found that gender served to mediate how students made sense of history. In one study, Barton (2005) conducted interviews with 40 students between the ages of 12 and 17 in Northern Ireland. While his analysis focused on the differences between Catholic and Protestant perspectives, Barton also found that gender played a clear role in students' selections of significant events. For example, only girls chose "Women's Suffrage" as important to study, citing equality as a primary reason. Eileen captured the rationale of many of the six pairs of girls when she explained that "It wasn't really fair, just men doing the votes" (p. 30). Barton also concluded that traditional gender roles in Northern Ireland played a role in students' selections as boys more often referred to the conflict between Protestants and Catholics as a reason to study specific topics, while girls evoked themes such as "unfairness, inequality, and the need for equal rights" (p. 31; see Kohlmeier \& Saye, 2015 for a related discussion on gender and notions of justice). In their interview study with middle-school age students in Northern Ireland, Barton and McCully’s (2005) found comparable results as references to wars were nearly three times as prevalent among boys as compared to girls. Conversely, girls selected topics related to Irish, Northern Irish, and local heritage at higher rates. Together these findings provide strong evidence of student gender as a mediating factor in the development of students' historical perspectives. In short, the research suggests that the social norms in which students develop impact students' interpretation of historical narratives and artifacts.

In the section above I have examined literature on the role of student positionality and historical perspectives. As Barton and Avery (2016) found in their review of the 
literature, research clearly demonstrates that race and ethnicity, national origin (i.e., immigrant experience), religious background, and gender each mediate student perspectives on history. In the next section I examine the second language acquisition literature as a means of better understanding the relationship between language learning and identity formation, as a sociocultural perspective suggests that additional factors may impact how emergent bilingual and bilingual students develop their perspectives on U.S. history.

\section{Identity Formation among Emergent Bilinguals}

The theoretical and empirical literature suggests that the recursive relationship between identity formation and language learning is an extremely complex one. Norton (2000, 2010, 2013) and others (e.g., Hawkins, 2004) have argued that the shaping of identity among emergent bilinguals is a fluid negotiation that builds on the interplay between the individual and the sociocultural context in which the target language is encountered. A growing body of empirical literature supports this understanding, linking language and identity as key elements in the learning process (Block, 2007; Norton \& McKinney, 2011). This research has been conducted both inside and outside formal educational settings, providing important insights that can aid in understanding the experiences and processes that emergent bilinguals encounter in the classroom.

In the following section, I first describe insights from the literature on various collective and historical characteristics that inform the conceptual understanding of the link between language and identity. Second, I describe recent research on selected characteristics that may influence identity formation among language learners in diverse settings. Third, I review the recent research from international educational settings 
related to identity and language learning. Finally, I examine the emerging literature on identity and language learning in a U.S. context.

\section{Social and Political Contexts}

From a sociocultural perspective, a variety of factors must be considered when conceptualizing the language learning and identity formation processes simultaneously. On a broad scale, the role of political factors is an ever present element, as evidenced in the historical case of laws in Iowa and other U.S. jurisdictions that banned the use of all languages other than English in schools during the early twentieth century in response to World War I and World War II (Gavrilos, 2010; see also Kibler, 2008). This historic case provides an example of a situation in which language was overtly used as a "standardizing force" (Flores, 2013). In presenting the case of banning German schooling in Iowa, Gavrilos (2010) demonstrates how the English language and an accompanying "American" ethnic identity were reinforced using the political power of the state. In prohibiting German schooling, Iowa clearly reflected a perceived tension between the "imagined communities" (B. Anderson, 1991) of the U.S. nation-state and a German ethnic identity for which language was a clear marker. Quirk (2000) argues that when conflict between the historical concept of the ethnic nation and the emergence of the nation-state as a political entity does arise, language is one of the foremost battle grounds. In a recent review of the arguments for and against identifying Spanish as the second national language of the United States, Macías (2014) describes historical and rights-based rationale for such a move before concluding that perpetuating past "imposition" of English will serve as a "mechanism of maintaining White privilege" (p. 54; see also Powers, 2014; Ruiz, 1984). In contemporary analysis, Wright (2014) and 
others (e.g., O'Neill, 2013) argue that on an international scale the effects of globalization have historically and continue to support the prioritization and expansion of English as people around the world seek to enter the marketplace of goods and ideas.

Research on additional historical examples from across the globe helps to illustrate the interplay between language and identity on a collective scale. In a study of Indian literature produced during British colonial rule, Sharma (2011) found that Indian authors regularly drew on their formal education and access to the British community in their writing. For example, Sharma described how Rama, a character in Raja Rao's 1960 novel The Serpent and the Rope, contrasted his fictional experience of England from that of Jane Austen or Virginia Woolf. Sharma concluded that doing so provided writers with a source of legitimacy and power within an Indian context. The link between language and identity can also be found in the study of counter examples, in which resistance to the language of conquering powers has been a critical component of identity preservation. Hornsby (2015) described the case of the Lemko language, which the Soviet Union labeled as a Ukrainian dialect in Poland following World War II. Hornsby conducted interviews with Lemko speakers in 2012 and 2013, finding that a unique Lemko identity remained in a hybrid form, with speakers clearly rejecting the "official" designation of Ukrainian and instead identifying themselves and their language use as a mix of Polish and Lemko. O'Rourke (2005) investigated two similar cases in different parts of Europe, surveying university students in Ireland and the Spanish region of Galicia. O'Rourke found that the young adult participants in both contexts reported strong support for the preservation of their respective Irish and Galician languages. O'Rourke concluded, however, that her survey data reflected a misalignment between the 
college students' identification with the heritage languages and their willingness to learn and actively preserve the languages themselves, though the study did not incorporate methods that could accurately measure participants' pursuit of these goals. Leung, Harris and Rampton (1997) posited that the traditional assumptions about "idealised" native speakers and emergent bilinguals overlook the reality in multicultural and multilingual settings. Indeed, the research on the language affinity of speakers in historic and contemporary contexts reviewed above suggests a complex relationship between communities seeking to preserve heritage languages as a means of "summoning their roots” (Quirk, 2000) at times, while also using, as Wright (2014) and O'Neill (2013) note, other languages to access educational and market resources. Given these broad sociocultural findings, I next examine research on characteristics and experiences that influence individual identity formation and language learning.

\section{Language Learning and Identity}

An important element of the literature on language learning and identity formation is an understanding of language serving as only one of many mediating factors. An identity approach highlights an understanding that "people cannot freely choose who they want to be, but rather they must negotiate identity positions in the larger economic, historic, and sociopolitical structures that they inhabit and which inhabit them" (Ortega, 2013, p. 242). Accordingly, Norton (2000) characterizes "identity as a site of struggle" (p. 127), arguing that equity and relationships across social status also play important roles in how members of language minority communities see themselves. Bumgarner and Lin's (2014) recent analysis of the kindergarten cohort of the Early Childhood Longitudinal Study data set provides an example of how quantitative data can 
demonstrate the impact of access to education and economic resources. Bumgarner and Lin found that benefits of early childhood education among first and second-generation Hispanic immigrant children were greatest among those from homes with below-average socio-economic status (SES). Specifically, students from immigrant families with low SES experienced a greater increase in their English language acquisition than those from families with above-average SES. The authors note that the academic achievement of children's mothers did not moderate their performance, while financial status did. Their findings highlight the role of status in determining access and outcomes, particularly highlighting the role of economic structures (Ortega, 2013) and the role of struggle (Norton, 2000) in achieving parity and success.

Many other factors similarly impact status, access, and consequently identity formation. Research from contexts across the globe provides examples of the interplay between identity and language acquisition at the individual level. In her seminal research involving adult language learners, Norton Peirce (1995) reported that Martina, a mother of three from Czechoslovakia, faced challenges when she arrived in Canada. Though she initially turned to her children to help her with English, Martina's role as a mother ultimately provided her with a greater sense of purpose than did her identity as an immigrant woman working at a fast food restaurant. Norton Peirce concluded that Martina's struggle with her social identity and her efforts to resist and claim various roles informed a fuller picture of her language acquisition.

Recent research among adult learners in various settings highlights additional factors. For example, in interviews with 23 Fiji Indians from multiple generations living in Wellington, New Zealand, Hundt (2014) described the reoccurring theme of "place" as 
one that helped to understand participants' identity formation, particularly as most described Fiji or India as "home" or the place they felt "grounded." Gallucci (2014) found similar results in a study with two college students studying abroad in Italy. One student demonstrated a willingness to more fully immerse herself in settings with native Italian speakers over the course of the semester, while the other remained more isolated. Based on her analysis of how these two students navigated a similar sociolinguistic context, Gallucci concluded that "identities are in dynamic evolution" (p. 934). Whereas Hundt's findings highlight the role of place, Gallucci's study foregrounds the role of a growing sense of permanence or longevity had on her participant's language learning.

Siziba's (2014) study of Zimbabwean migrants in South Africa, on the other hand, suggests that migrant status—-more so than self-identified goals—impacted the role of language as an identifier and tool for non-permanent Zimbabweans. Alimoradian (2014) found similar results through studying the use of the vocative "mate" among 101 Australian immigrants or children of immigrants, most of Iranian or Chinese background. Participants who reported using the colloquial "mate" more frequently also scored lower on a measure of ethnic orientation, causing the author to conclude that use of the quintessential Australian term "mate" corresponded with social integration into Australian society. In short, recent research among adults from across the globe provides insights into numerous factors that impact language learning and usage patterns, all of which coalesce around notions of belonging, such as place, permanence and ethnic identity. In the following section I examine the identity formation process within the literature specific to the classroom and language learning students. 


\section{Schooling Experiences and Environments}

In order to better understand the experiences of students in the midst of learning language, I focus next on second language acquisition research within formal schooling settings, first in international contexts and then studies conducted in the United States. This analysis is informed by Ceginskas' (2010) and Kapp and Bangeni's (2011) assertion that both education experiences and language learning impact identity formation. In a retrospective study among European adults, Ceginskas found, however, that similar experiences can impact people differently. For example, speaking of his multilingual, multicultural schooling experience, Augustinas remarked: "When you're growing up with five languages on a daily basis everything is floating. You don't feel like belonging anywhere. It's an insecure, uncomfortable feeling" (p. 213). Paula expressed the opposite perspective based on similar educational experiences:

I grew up in a bubble and that bubble was full of people who were kind of like me, meaning had parents from different nationalities away from the place they live in, spoke a couple of languages if not more. It was a completely normal experience. (p. 215)

These seemingly contradictory self-reports support the concept of language as a cultural tool that mediates schooling experiences, while also highlighting the need for emergent bilinguals to be able to apply meaning to their own experiences.

Additional research from international contexts adds to a rich understanding of the relationship between language status and schooling. A series of articles from South Africa provide important insights, particularly as the United States and South Africa share a history of segregated schools (Carter, 2012). In their longitudinal study of 20 "ESL students" attending a historically White, English-medium university, Kapp and Bangeni (2011) found that language served as a marker of ethnic identity. For Sisanda 
this meant identifying as Zulu through her linguistic usage. Rejection often accompanied such marking, both at the university and when students returned to their home community, as when Vuyani was caught listening to Metro FM. "As you know it's English," he explained to the researchers in articulating why his childhood friends did not approve. Parmegiani (2014) found similar results, concluding that university students developed a command of English and their heritage languages (e.g., Zulu), but that a social price accompanied this code switching. In a study conducted near Melbourne, Australia, Willoughby (2013) surveyed 20 multilingual students in a suburban high school, finding that Vietnamese speakers there similarly selected when to use English or their "ethnic language." The study was limited by the fact that Willoughby drew groupwide conclusions even though four of the seven Vietnamese speakers said they "rarely" or "never" spoke Vietnamese "with school friends." Yet the qualitative results show that those participants who did typically use Vietnamese did so to communicate privately (e.g., telling secrets, cursing) while in the presence of non-Vietnamese speakers. Willoughby concluded that these participants provide insights into the language use of minority language students in multilingual school settings. In sum, the research in this section suggests that language serves as an important mediating factor in the schooling and relational experiences of students from diverse cultural and linguistic backgrounds. In the final section below, I examine extant literature on identity formation among emergent bilinguals in U.S. schools.

\section{U.S. Schools and Emergent Bilinguals}

Research among emergent bilinguals in U.S. schools largely maps onto the findings from international settings. In a seminal ethnographic study that followed four 
Chinese immigrant students through seventh and eighth grade, McKay and Wong (1996) found that Brad Wang faced the imposed identity of a low achiever, exacerbated by the "colonialist/racialized discourses on immigrants embodied" (p.598) by his teachers. Brad's initial writing successes went unrecognized, contributing to his feelings of incompetence and leading to increased misbehavior. In a recent study also in a middle school context, Martínez (2010) investigated the mixing of English and Spanish in a sixth grade language arts class in East Los Angeles. Martínez noted that "Spanglish" is often used a pejorative term meant to criticize the non-standard language production of Spanish speakers. However, his descriptive analysis reveals that students used Spanglish to communicate subtle shades of meaning and in ways that demonstrated audience awareness, which Martínez identified as sophisticated language practices. Bunch (2014) introduced the terms of "the language of ideas" and the "language of display" to emphasize the role of processing language in the classroom. Martínez's description of Spanglish maps onto the "language of ideas" that Bunch outlines, while the more formal or academic English prominent in schools (Schleppegrell, 2004) matches Bunch's "language of display."

As the examples above suggest, the ways in which individuals navigate linguistic landscapes varies. Research indicates that the complexity presents barriers for some students. For example, in Monzó and Rueda's (2009) ethnographic study of fifth grade Latina/o emergent bilinguals, they found that students engaged in "passing" as English language proficient. The students' actions included remaining quiet and feigning understanding in order to save face, a strategy which the authors concluded ultimately undercut the students' language learning. Similarly, Talmy (2010) employed 
ethnographic methodology in reporting on the identity development of emergent bilinguals in a Hawaii high school. Local or "old-timer" emergent bilinguals in the study ridiculed and marginalized newcomer Micronesian students. Yet, Talmy reported that some students used a combination of language practices in pursuit of their academic goals. In addition to Martínez's (2010) example of Spanglish use described above, Worthy and colleagues (2013) also provide an example of hybrid language practices in their study of a fifth grade bilingual education classroom in Texas in which the teacher valued, supported, and facilitated codeswitching. While reading Esperanza Rising, a children's book set in the Great Depression, the teacher drew on personal experiences of crossing the U.S.-Mexico border, just as the main character in the book does. The teacher also utilized student linguistic knowledge during a discussion of the term "manual labor" when she asked students what Spanish word sounds like manual. When Jorge responded mano (hand), the teacher proceeded to define manual labor as work that is done by hand (Worthy et al., 2013). These studies illustrate the power of language in the classroom, both in providing and denying access for students.

The research reviewed in the section above suggests that the language of school history may serve as a significant mediating factor in how emergent bilinguals develop their perspectives on U.S. history, particularly as that process includes whether and how to include themselves in the narrative. As Norton (2013) argues, "a focus on imagined communities in language learning enables us to explore how learners' affiliation with such communities might affect their learning trajectories" (p. 8). The same is true for investigating how students from culturally and linguistically diverse backgrounds make sense of the national narratives they encounter in U.S. history classrooms. Through 
examining the primarily descriptive studies discussed in this section, I conclude that "understanding students" (Grant, 2003) in the context of emergent bilingual and bilingual students' learning U.S. history is a complex proposition in which contexts, identity development, and schooling experiences directly impact the ways in which students make sense of the content.

\section{Chapter Summary}

Research on the teaching and learning of history has produced a significant body of knowledge on the disciplinary practices that contribute to the "doing" of history (Levstik, 2008) and "historical thinking" (Wineburg, 2001). Building on this body of knowledge, recent research provides examples of the ways in which students from various ethnic and racial backgrounds make sense of U.S. history, finding that many students of color reject or reframe the history they learn in school (e.g., Almarza, 2001; Busey, 2013; Epstein, 2000, 2009). Related inquiry suggests that the experience of immigrating to a new country (e.g., An, 2009; Peck, 2010), student religious background (e.g., Barton \& McCully, 2005; Goldberg, 2013; Schweber \& Irwin, 2003; Spector, 2007) and gender (e.g., Barton, 2005; Colley, 2015; Levstik \& Groth, 2002) also impact the learning of history (see Figure 6). However, this line of research has largely overlooked the role of language in the formation of students' historical perspectives, at times remaining silent on the experiences of emergent bilingual participants (e.g., Martell, 2013), or excluding emergent bilinguals altogether, either by design (e.g., Busey, 2013) or through identifying "background knowledge" inclusion criteria (e.g., Peck, 2010).

Recent scholarship from the field of second language acquisition provides additional insights into the unique positionality of emergent bilinguals. Such research 


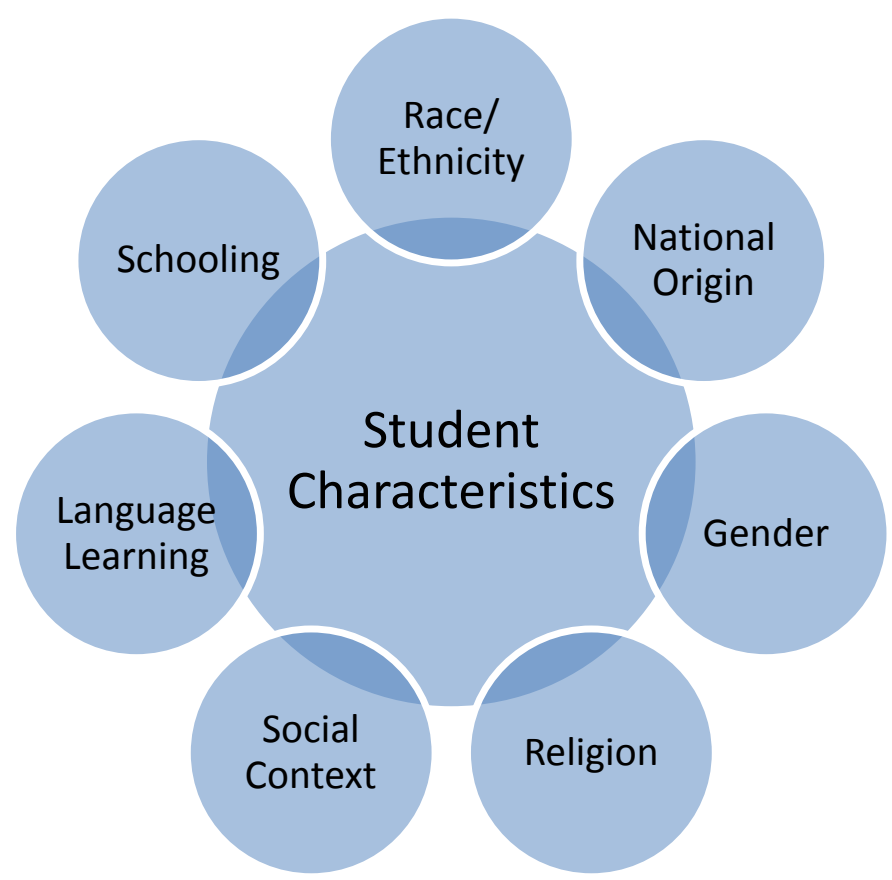

Figure 6. Student Characteristics Expected to Interact with Emergent Bilingual and Bilingual Students’ Perspectives on U.S. History can help history educators and researchers "understand students" (Grant, 2003). In particular, Norton $(2000,2010,2013)$ and others (e.g., Block, 2007) have studied the notion of identity in the language learning process, finding that a variety of factors mediate the complex and fluid relationship between student language and identity development. The research suggests that social and political contexts, language learning and identity, and school experiences can be expected to impact the perspectives of emergent bilinguals. Given the role history classes play as "curricular spaces where identities are deliberately shaped" as students encounter questions about "who "we the people' are and ought to be" (Parker, 2010, p. 247), the complex relationship between language and identity may be expected to be all the more critical in the context of the U.S. history classroom. Drawing on literature from the history education and language 
acquisition fields, this analysis considered an array of empirically relevant student characteristics. In the following chapter I detail the methods I used to conduct the study. 


\section{CHAPTER III}

\section{METHODS}

The present study seeks to examine the sense making of middle school emergent bilingual and bilingual students. Specifically, the study addresses the following research questions:

- How do middle school emergent bilingual and bilingual students describe their perspectives on U.S. history?

- How do various student characteristics (e.g., English language proficiency, country of origin) interact with middle school emergent bilingual and bilingual students' perspectives on U.S. history?

In response to the interpretive nature of these questions, I conducted a study based on the naturalistic inquiry common in history education research (Levstik \& Tyson, 2008). Such an approach allowed for the inclusion of emic perspectives and participant voice (Erickson, 1986; Erickson \& Schultz, 1992; Marshall \& Rossman, 2011).

In this chapter, I begin with a brief description of the paradigm assumptions that guided the study. I next provide a summary of the conceptual framework that informed the design of the study. I then describe the study setting and participants, followed by the data collection and data analysis plans. Finally, I address the role of the researcher as instrument and articulate criteria for the study's trustworthiness. Figure 7 provides a complete overview of the chapter. 
Methodology

\section{Overview of Chapter III}

Conceptual Framework

Setting and Participants

Site Selection

School Contexts

Jackson Heights Middle School

Garden View Middle School

Participants

Ms. Rogers

Mr. Mitchell

Case Study Students

Data Collection

Observations

Document Collection

Interviews

Teacher Interviews

Student Interviews

Data Analysis

Researcher as Instrument

Criteria for Trustworthiness

Chapter Summary

Figure 7. Overview of Chapter III

\section{Methodology}

A sociocultural theoretical framework and an interpretivist research paradigm

informed the design of the study. Such an approach explicitly recognizes the

positionality of both the researcher and the study participants (Creswell, 2009; Flyvbjerg,

2001), particularly as an interpretivist paradigm builds on an ontology revolving around

multiple realities (Guba \& Lincoln, 1994; Schwartz-Shea \& Yanow, 2012). In response

to the interpretive nature of the research questions, the study utilized an epistemology of

subjective meaning-making in practice (Schwartz-Shea \& Yanow, 2012). As such, I

sought to "rely as much as possible on the participants' views of the situation being

studied" (Creswell, 2009, p. 8). I also attempted to articulate the limitations and impacts

of the "double hermeneutic" that resulted from the inclusion of both the "researcher's 
interpretations and the interpretations of the people whom the researcher studies" (Flyvbjerg, 2001, p. 33), which may be particularly significant given the "sociocultural differences" between myself and the focal students in the study (VanSledright, Kelly, \& Meuwissen, 2006, p. 211).

In keeping with these assumptions, I conducted a multiple case study (Creswell, 2009; Hood, 2009; Marshall \& Rossman, 2011) to allow for in-depth inquiry of the complex and situated processes that contribute to students' perspectives on U.S. history. The case study design was used as a method of inquiry into cases that "are bounded by time and activity" using a "variety of data collection procedures over a sustained period of time" (Creswell, 2009, p. 13). In the study, the individual students and classroomsand the interactions among students, teachers and the curriculum that take place thereinserve as the bounded cases.

A qualitative case study approach best addresses the "how" research questions. Case studies provide time and space for researchers to enter "classrooms, observe, talk to people, get a sense of the lived experiences of students and deepen [his/her] understanding of that experience through extended contact" (Hood, 2009, p. 73). In the present study, the multiple data sources were particularly important as the research questions addressed both the students' views and practices. In the following section, I present an overview of the conceptual framework that guided the methods.

\section{Conceptual Framework}

In an empirical study, the conceptual framework provides a link between the particular setting and participants and the theoretical and empirical literature (Marshall \& Rossman, 2011). The conceptual framework that I operationalized in order to inform the 


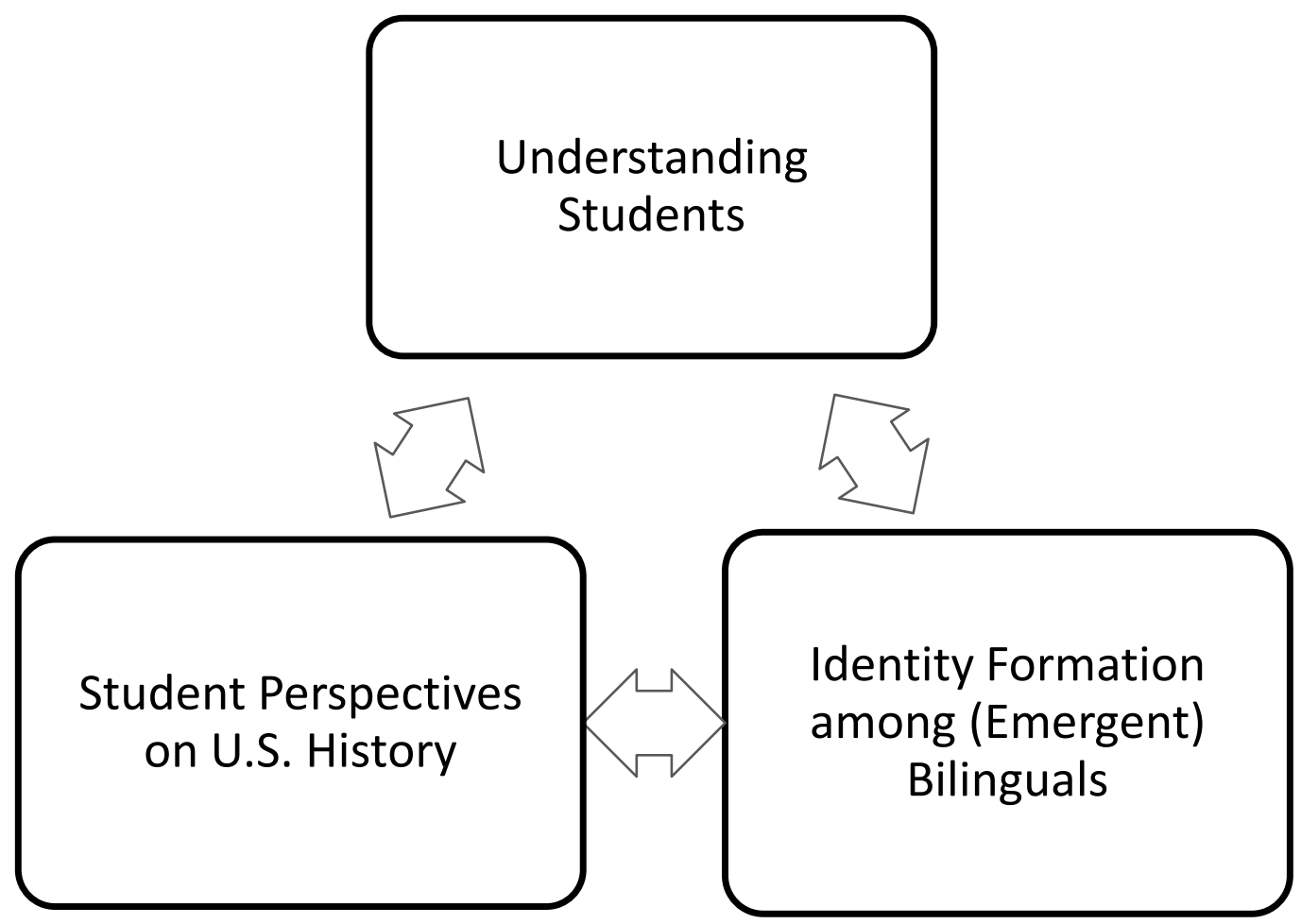

Figure 8. Understanding the Historical Perspectives of (Emergent) Bilinguals

design and implementation of the present study builds on Grant's notions of ambitious teaching and learning of history, specifically the "understanding students" component (see Figure 8). In developing an understanding of student sense making, the research on student perspectives of national history (e.g., Almarza, 2001; Epstein, 2000, 2009; Peck, 2010) and identity formation among emergent bilinguals (e.g., Norton, 2013; Norton \& McKinney, 2011; Talmy, 2010) guided the interpretivist process. Together these bodies of knowledge informed the planning and implementation of the present study. In the following section, I describe the setting and participants for the present study.

\section{Setting and Participants}

In the present study, I applied an interpretivist paradigm through contextualized investigation. In order to find cases of emergent bilingual and bilingual students engaged in the teaching and learning of U.S. history I began with a purposeful sampling strategy 
(Creswell, 2009; Marshall \& Rossman, 2011). In this section of the chapter, I describe the setting and participants that were recruited for the study.

\section{Site Selection}

I used extreme case (Marshall \& Rossman, 2011) and convenience (Creswell, 2009) sampling to identify two middle schools in the school district of a small city in Virginia. I selected these schools because they have a high concentration of emergent bilinguals and thus allowed for inquiry that addressed the research questions. In the past, I had both taught at and recently conducted research (Yoder, 2013; Yoder \& van Hover, 2015) at Jackson Heights Middle School. For the present study, I sampled students from both Jackson Heights and Garden View Middle School, the other middle school in the district, in order to gain access to the greatest number of emergent bilingual and bilingual students in multiple seventh grade U.S. history classes. I first emailed the school district superintendent with a brief description of my study proposal and confirmation of IRB approval. As the study took place in two middle schools, I asked for a meeting with the superintendent (or a representative) and an administrator from each of the middle schools. The superintendent provided written approval for the study and suggested that I schedule individual meetings with the principal of each middle school. During each of these meetings, I presented an overview of the study and asked for permission to conduct the study. Each principal provided this permission, as well as guidelines and suggestions for conducting the study, and then nominated and introduced me to a seventh grade U.S. history teacher. 


\section{School Contexts}

I conducted the study in a small Virginia city, which I will call Garden View.

Garden View is home to a primarily suburban community of approximately 51,000 residents. During the 2015-2016 school year, the public schools served a diverse student body of approximately 6,473 students in grades K-12. Some $35 \%$ of these students were identified as emergent bilinguals, with 47 languages and 43 countries represented. Among the district's emergent bilinguals, Spanish was spoken as a primary language by $74 \%$ with Arabic (10\%), Kurdish (6\%), Tigrinya (3\%), and Russian (2\%) being the other languages spoken by more than one percent of students. The majority of Garden View's emergent bilinguals were U.S.-born (59\%), while others were born in Iraq (10\%), Honduras (6\%) and Puerto Rico (5\%). The estimated 31\% of the district's emergent bilinguals who were foreign-born corresponds to the approximately $10 \%$ or 556 of the overall student body who were identified as immigrants.

Garden View has two middle schools. Each school includes grades five through eight. I have assigned them the pseudonyms Jackson Heights Middle School and Garden View Middle School. While the schools serve the same small city and have some demographic similarities, I describe each individually.

Jackson Heights Middle School. Jackson Heights Middle School is the older of the two schools. The building sits atop a hill overlooking the municipal golf course near the edge of town. During the 2015-2016 school year, Jackson Heights was home to 823 students. Of these, 54\% received reduced price or free lunches. The student body represented significant racial or ethnic diversity, with $45 \%$ White, $12 \%$ Black, $38 \%$ Hispanic, and 3\% Asian. At Jackson Heights 20\% of students $(n=162)$ were identified 
as emergent bilinguals. Of these emergent bilinguals, the largest number had an English language proficiency in the intermediate range with WIDA ACCESS test scores in the Level $3(n=45)$ and Level $4(n=61)$ range (The Board of Regents of the University of Wisconsin System, 2014).

Garden View Middle School. Garden View Middle School opened in 2008 alongside a new elementary school. During the 2015-2016 school year, Garden View was home to 796 students. Of these, $61 \%$ received reduced price or free lunches. The Garden View student body also represented significant racial or ethnic diversity, with 42\% White, $11 \%$ Black, $42 \%$ Hispanic, and 3\% Asian. At Garden View 27\% of students $(n=214)$ were identified as emergent bilinguals. One reason Garden View had a higher number of emergent bilinguals was that students who had just immigrated to the United States and demonstrated limited English proficiency on a standardized test were sent to a newcomer program at Garden View. As such, Garden View had a high number of emergent bilinguals identified as Level $1(n=58)$. The number of students who tested as Level $3(n=53)$ and Level $4(n=57)$ on the WIDA ACCESS test were comparable to Jackson Heights (The Board of Regents of the University of Wisconsin System, 2014).

\section{Participants}

At each of the two middle schools, I employed extreme case (Teddlie \& Tashakkori, 2009) or maximum variation sampling (Marshall \& Rossman, 2011) through asking the principal at each school to identify the seventh grade U.S. history teacher with the class that had the highest concentration of emergent bilinguals . Each principal then contacted the identified U.S. history teacher at his respective school. I then met with each of these teachers to recruit them for the study. Mr. James Mitchell at Jackson 
Heights Middle School consented to participate in the study. However, when I met with Ms. Sharon Murphy at Garden View Middle School, we realized that her class with a high density of emergent bilinguals was back-to-back with Mr. Mitchell's class, which meant I would not have enough time to drive across town in between classes. When I discussed this scheduling conflict with Ms. Murphy and the Garden View principal, they introduced me to Ms. Susan Rogers. Out of the twenty students in Ms. Rogers' class, only five were emergent bilinguals. However, the district classified 11 of the remaining 15 students as a Level 6B or Level 6C on the WIDA scale, signifying that they had previously been labeled emergent bilinguals, but had since "exited" the ESL program. In order to provide a more complete description of the setting in which the study took place, I next describe Ms. Rogers and Mr. Mitchell's background and instructional approaches.

Ms. Rogers. During the present study, Ms. Susan Rogers was in her second year of teaching history. Ms. Rogers is a White woman who graduated from a Virginia liberal arts college six years before the study. Previously she taught computer classes at Garden View Middle School. During these classes she interacted with some of the study participants when they were enrolled in her fifth grade computer elective course. Ms. Rogers identified helping students and inspiring them to learn as her primary goals. In class she often asked questions in the whole class setting and invited students to "just call out" responses (analytic memo, 9/5/15).

Ms. Rogers frequently incorporated multiple instructional strategies into each hour-long lesson. The daily routine typically began with a short lecture, whole class reading, or video. During or after this teacher-led instruction, students usually either took notes or completed a graphic organizer, which they then glued into their notebooks. Ms. 
Rogers attributed this overall pattern to a focus on vocabulary in which "Cornell notes and writing and some readings" served as a foundation for discussion and opportunities to ask, "What did we read? Now, can you summarize what you read?" (interview, 8/26/15). Ms. Rogers described the textbook as compatible with students' language learning needs because of the "pictures and short chunks of text."

The official curriculum figured prominently in Ms. Rogers' instruction. In her second year teaching seventh grade U.S. history, Ms. Rogers described "the Virginia standards" as the primary factor in "how I decide what to teach" (interview, 12/18/15). During observations I noted that Ms. Rogers often displayed the individual standards (SOLs) on handouts in abbreviated form. Ms. Rogers also stated that she sought to make the content relevant to students:

One of the major things I like to focus on, just with this group, is that look how diverse America is and look at all the shifts that we've gone through and how we are a nation of immigrants. Just because that's this population. (interview, $12 / 18 / 15)$

Ms. Rogers concluded that she experienced a tension between providing instruction that was "relevant" to students and maintaining "alignment with our SOLs and assessments." She added that she tried to spend a little extra time on a specific topic if she knew students were interested in the subject, noting how she spent only two days on early $19^{\text {th }}$ century inventions “because kids don't really care when the washing machine was invented." In the following section I provide a lesson observation vignette and description of Mr. Mitchell's instructional practices.

Mr. Mitchell. At the time of the present study, Mr. James Mitchell was a veteran teacher of 17 years. Mr. Mitchell was in his eighth year at Jackson Heights Middle School. Mr. Mitchell is an African American man who said his own experiences as a 
student led him to become a teacher. Specifically, Mr. Mitchell described having teachers who believed in him and identified opportunities for him, including finding college scholarships and encouraging him to apply. Mr. Mitchell reported that his goal as a teacher was to similarly assist his own students and to help them experience success (interview, 8/24/15).

Mr. Mitchell reported that Cornell notes and reading comprehension were an important part of his instructional focus. He noted that he previously taught both history and English language arts in a different school district and that he frequently discussed his resources and plans with a seventh grade language arts colleague at Jackson Heights. While Mr. Mitchell emphasized text-based instruction, he specifically avoided the textbook and instead used materials from Junior Scholastic, Cobblestone, Mini-page, and other nonfiction sources. He explained that he wanted students "to learn how to read critically, learn how to take notes on what they read, and learn how to summarize information" (interview, 8/24/15). In addition to these resources, Mr. Mitchell often used visually-based resources in his instruction. He explained that many of the video clips he had collected over the years came from Discovery Education. Mr. Mitchell also discussed how he selected the political cartoons that he used on occasion:

I use them in class because the use of art is good. Art is something that most people...like you don't read it, so it's a different resource. There are primary sources. You can tell a lot of intent from what people may decide whether it's a positive image or a negative image. It can take something that's complex and you're still able to use simple language to be able to describe what it is. Anybody could say it's not difficult to say whether it's a positive description or a negative one, as well as still get something that's higher level in terms of the vocabulary that you might use to describe it. I think it's something larger that more students can get rather than simple text - text is much harder since you have different reading levels - there's your skills of observation with looking at the political cartoons. (interview, 12/17/15) 
During the occasional classes in which Mr. Mitchell taught with political cartoons, he placed them in clusters in the locker pod outside the classroom and had students complete an observation protocol while completing a gallery walk. The protocol included three uniform questions that required students to describe what they saw and then articulate a brief hypothesis or analytic statement regarding the meaning of the images.

Mr. Mitchell identified the Virginia SOLs as the primary influence on his overall curricular decisions. Mr. Mitchell described his instruction as based on "what they tell me to teach...based off of what the state says" (interview, 12/17/15). He added that he targeted his instruction to reflect the developmental abilities of seventh grade students "because it's unrealistic to expect students to do the in-depth research that I actually would." Mr. Mitchell described how the "difficulties" in U.S. history (i.e., slavery, discrimination) that were found in the standards provided him with "creative license or freedom" to explore similar themes. He asserted, however, that the curriculum included few people of color and that when individual people were "sprinkled" in the curriculum it "felt like an add on" rather than being integrated in a "memorable way." Mr. Mitchell found this disjointed approach particularly "problematic" given the questions he often fielded from students:

If I'm a female, what about me? What were we doing? If I am a minority of some sort, well what about me? What am I doing? Because those questions come up. You get questions about racism, "Well, I'm Hispanic, what happened to me? Am I included in this?" Yes, they hated you too. All right. What about me, I'm part this, I'm part that. Well, according to them, back in that day, you're all this. Really? That doesn't make any sense. I didn't make the racism rules, these are just the rules. (interview, 12/17/15)

Mr. Mitchell concluded that he attempted to "elicit an emotion" as a way of engaging students in class discussion and recognized that identity served as one component of this 
process. In the following section I provide an introduction to the eleven case study students selected from Ms. Rogers' and Mr. Mitchell's U.S. history classes.

Case study students. Once I had identified one of Mr. Mitchell's classes and one of Ms. Rogers' classes for the study, I purposefully sampled 6 students from among the consented students in each of the two classes in order to include both variance and similarity across the following characteristics: language proficiency (WIDA scores), first language, country of origin, refugee status, SOL scores, gender, and years in U.S. schools as a means of accessing the diversity found among emergent bilingual and bilingual students (Aud et al., 2012) and incorporate maximum variation (Marshall \& Rossman, 2011; Teddlie \& Tashakkori, 2009). Table 2 depicts the values for each of the selected focal students. Veronica, the only female focal student in Ms. Rogers' class, dropped out of the study midway through the semester and I subsequently removed her data from the study. In the following section I outline the data collection plan.

\section{Data Collection}

In this section of the chapter I describe the data collection procedures for the present study. The data collection procedures build on the fundamental understanding that gathering data from multiple sources allows for triangulation and expansion (Emerson, Fretz, \& Shaw, 1995; Teddlie \& Tashakkori, 2009) and "can greatly strengthen the study's usefulness for other settings" (Marshall \& Rossman, 2011, p. 253). In the study I employed the three "data generating methods" Schwartz-Shea and Yanow (2012) identify as most common among qualitative researchers: observation, interviewing, and document collection. Table 3 provides an overview of the data collection plan in response to the research questions. As the research questions focus on 
Table 2

Student Sampling Matrix

\begin{tabular}{|c|c|c|c|c|c|}
\hline Pseudonym & $\begin{array}{l}\text { WIDA } \\
\text { Level }\end{array}$ & $\begin{array}{c}\text { First } \\
\text { Language }\end{array}$ & $\begin{array}{l}\text { Country of } \\
\text { Birth/ Family } \\
\text { Origin }\end{array}$ & $\begin{array}{l}\text { Years in } \\
\text { U.S. } \\
\text { Schools }\end{array}$ & $\begin{array}{c}\text { 6th grade } \\
\text { Reading SOL }\end{array}$ \\
\hline $\operatorname{Aras}^{b}$ & $6 B$ & Kurdish & U.S./Iraq & 7 & 357 \\
\hline Felix $^{b}$ & 4 & Spanish & U.S./Mexico & 7 & 374 \\
\hline Gebre $^{\mathrm{b}}$ & $6 \mathrm{C}$ & Tigrinya & Ethiopia $^{\mathrm{c}}$ & 7 & 386 \\
\hline Isabel $^{\mathrm{a}}$ & $6 \mathrm{C}$ & Spanish & U.S./Mexico & 7 & 448 \\
\hline Javier $^{\mathrm{a}}$ & 3 & Spanish & $\begin{array}{c}\text { U.S./ } \\
\text { Honduras }\end{array}$ & 5 & 308 \\
\hline Maria $^{a}$ & $6 C$ & $\begin{array}{l}\text { Spanish/ } \\
\text { English }\end{array}$ & $\begin{array}{c}\text { U.S./ } \\
\text { Honduras }\end{array}$ & 8 & 439 \\
\hline Marisol $^{\mathrm{a}}$ & 2 & Spanish & El Salvador & 1 & $\mathrm{n} / \mathrm{a}$ \\
\hline Santiago $^{b}$ & $6 \mathrm{C}$ & Spanish & Mexico & 6 & 466 \\
\hline Salvador $^{\mathrm{b}}$ & $6 C$ & $\begin{array}{l}\text { English/ } \\
\text { Spanish }\end{array}$ & U.S./Mexico & 7 & 457 \\
\hline Yonas $^{\mathrm{a}}$ & 3 & Tigrinya & Eritrea $^{c}$ & 2 & 286 \\
\hline Yousuf $^{a}$ & 3 & Arabic & Iraq & 2 & 278 \\
\hline \multicolumn{6}{|c|}{$\begin{array}{l}\text { Note. WIDA scores reflect English language proficiency on a scale of 1-6 with a label of } \\
6 \mathrm{~B} \text { or } 6 \mathrm{C} \text { signifying students who had "exited" the ESL program two years or more than }\end{array}$} \\
\hline \multicolumn{6}{|c|}{ two years ago, respectively. The state standardized reading test has a maximum score of } \\
\hline \multicolumn{6}{|c|}{ 600. The lowest passing score is a 400 while a score of 500 or above is a pass advance. } \\
\hline${ }^{\mathrm{a}}$ Student in $\mathrm{N}$ & Mitchell's & ss. ${ }^{\mathrm{b}}$ Student & Ms. Rogers’ cla & ${ }^{c}$ Studen & with refugee \\
\hline
\end{tabular}


Table 3

Data Collection Plan

\begin{tabular}{ll}
\hline \multicolumn{1}{c}{ Research Question } & \multicolumn{1}{c}{ Data Collection Methods } \\
\hline How do middle school emergent bilingual & 2 individual interviews \\
and bilingual students describe their & 1 focus group interview \\
perspectives on U.S. history? & daily classroom observations \\
& student work samples \\
How do various student characteristics & archival student data (e.g., WIDA scores) \\
(e.g., English language proficiency, country & teacher interviews \\
of origin) interact with middle school & 2 individual interviews \\
emergent bilingual and bilingual students & 1 focus group interview \\
perspectives on U.S. history? & daily classroom observations \\
& student work samples \\
\hline
\end{tabular}

student perspectives, the data collection methods included approaches that both elicited emic perspectives and provided observational data on students' classroom interaction (Marshall \& Rossman, 2011). In order to address the second research question, I accessed student archival data from school records, as the existing scholarship suggests that language proficiency, length of time in the United States and related student characteristics may impact how emergent bilingual and bilingual students make sense of U.S. history. In the following section I describe each of these approaches in detail.

\section{Observations}

The goal of the observations was to investigate the enacted curriculum as mediated through teacher and student interactions in the course of the teaching and 
Table 4

Data Collection Timeline

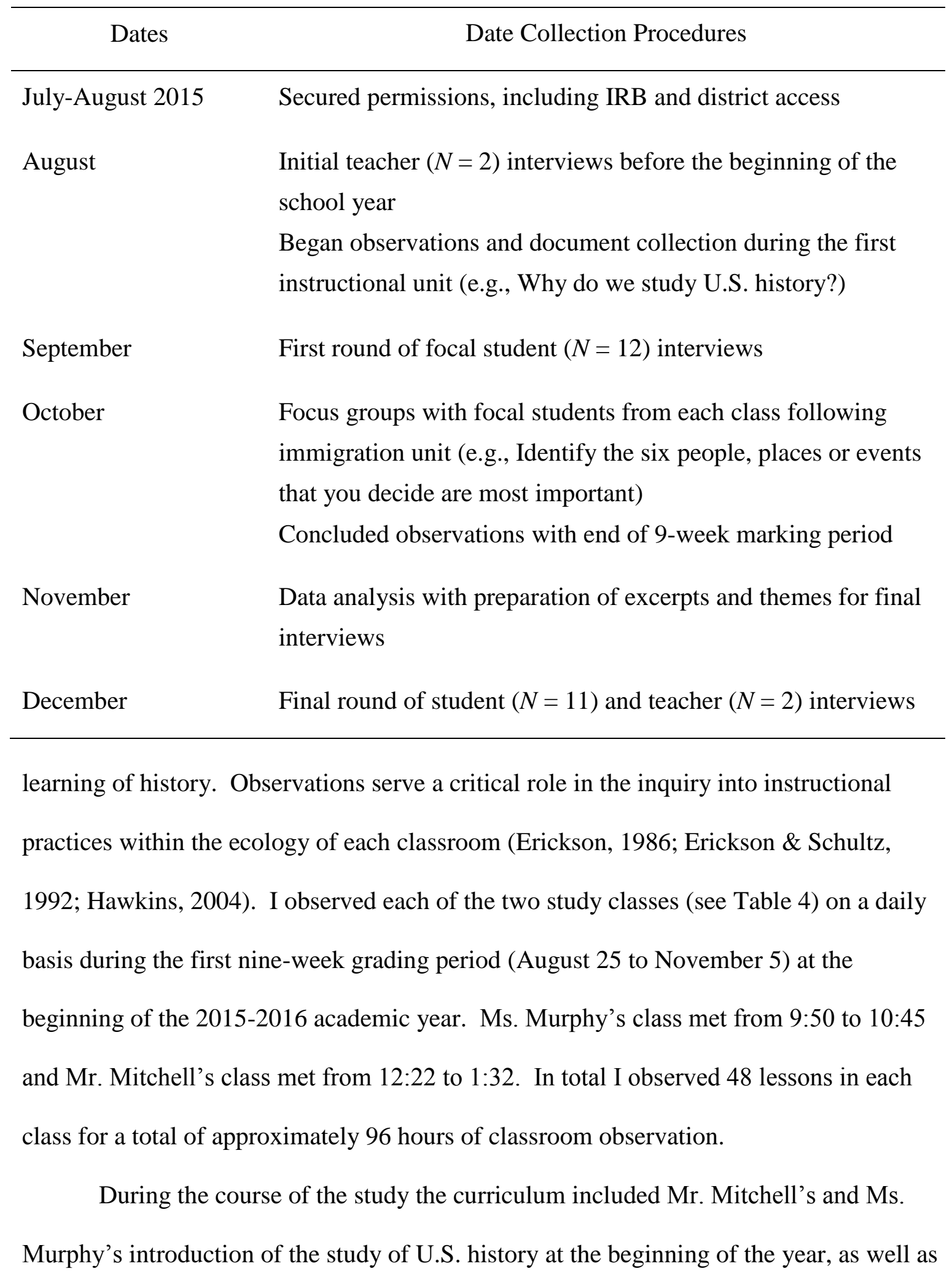


Table 5

U.S. History Pacing Guide

\begin{tabular}{ccc}
\hline Dates & Standards & Content Topic \\
\hline August 25 - September 11 & USII.2a-c & Geography \\
September $14-$ September 23 & USII.3a-c & Reconstruction \\
September 24 - October 2 & USII.4a & The Push West \\
October 5 - October 20 & USII.4b & The Newcomers \\
\hline
\end{tabular}

units on U.S. geography, Reconstruction, westward expansion, and immigration (Virginia Department of Education, 2008c). Table 5 depicts the district-level pacing guide on which Mr. Mitchell and Ms. Murphy based their instruction. The schedules were adjusted in part to allow Ms. Andrews, the district's middle school gifted education teacher, to push into each 7th grade U.S. history class for a week of supplemental, primary source-based instruction as part of the Reconstruction unit. The concepts directly addressed in each instructional unit mapped onto extant literature regarding purposes for the teaching and learning of U.S. history (e.g., Barton \& Levstik, 2004; van Hover \& Yeager, 2007) and theoretically significant curricular concepts, including race relations (e.g., Epstein, 2009) and immigration (e.g., Cruz \& Thornton, 2009a, 2009b).

During these observations my role was primarily "observer as nonparticipant" (Marshall \& Rossman, 2011, p. 143), as I attempted to limit my direct interaction with the participants in order to maintain a naturalistic setting to the extent possible. I documented each classroom observation through the use of ethnographic fieldnotes, which included a running record of observational notes and initial analytic notes (Emerson et al., 1995). I also video recorded each class session, and used these 
Table 6

Document Collection: Student Work Samples

\begin{tabular}{|c|c|c|}
\hline Date & Teacher & Assignment \\
\hline September 4 & Mr. Mitchell & $\begin{array}{l}\text { Regions Project Poster and } \\
\text { Reflection }\end{array}$ \\
\hline September 10 & Mr. Mitchell & $\begin{array}{l}\text { Analyzing Political Cartoons } \\
\text { - Reconstruction Era }\end{array}$ \\
\hline September 11 & Ms. Rogers & $\begin{array}{l}\text { Essay on "Who killed } \\
\text { Reconstruction?" }\end{array}$ \\
\hline October 14 & Ms. Rogers & $\begin{array}{l}\text { Reflective Journal (American } \\
\text { Indian) }\end{array}$ \\
\hline October 19 & Mr. Mitchell & $\begin{array}{l}\text { Reflective Journal (American } \\
\text { Indian) }\end{array}$ \\
\hline October 23 & Ms. Rogers & $\begin{array}{l}\text { Essay on American Indians in } \\
\text { Early Boarding Schools }\end{array}$ \\
\hline October 23 & Mr. Mitchell & $\begin{array}{l}\text { Westward Expansion - Note- } \\
\text { Taking and Writing Test }\end{array}$ \\
\hline October 29 & Mr. Mitchell & $\begin{array}{l}\text { Topic: Jane Addams of Hull } \\
\text { House (Cornell Notes) }\end{array}$ \\
\hline November 4 & Mr. Mitchell & $\begin{array}{l}\text { Analyzing Political Cartoons } \\
\text { - Immigration }\end{array}$ \\
\hline
\end{tabular}

recordings to add detail to the in vivo notes I took during observations. This process of synthesizing sources and writing fieldnotes both provided documentation and fostered the initial data analysis process (Emerson et al., 1995; Marshall \& Rossman, 2011).

\section{Document Collection}

During the nine-week observation period, I also collected instructional documents as a complementary data source (Marshall \& Rossman, 2011). These artifacts included lesson plans, instructional handouts, and samples of student work. These documents provided triangulation for both participant interviews and observational data. The daily handouts and occasional lesson plans documented the enacted curriculum students encountered in the classroom. The selected student assignments provided representative examples of common assignments, as well as the few open-ended essays or reflective 
prompts. Table 6 describes the samples of focal student work collected in each class. I also collected school archival data, which was instrumental in the focal student sampling criteria described above, including language proficiency (WIDA scores), first language, country of origin, refugee status, SOL scores, grades from the previous year, and years in U.S. schools.

\section{Interviews}

Interviews provide an important window into the perspectives of participants (Kvale, 2007; Marshall \& Rossman, 2011; Schwartz-Shea \& Yanow, 2012). From the perspective of an interpretivist paradigm, the articulation of "what is significant—what is meaning-ful"' (Schwartz-Shea \& Yanow, 2012, p. 41) is precisely the point of inquiry. In the present study I conducted individual interviews with the two middle school U.S. history teachers and the focal students as a means of eliciting the participants' perspectives (Kvale, 2007). In recognition of the degree to which an "individual's attitudes and beliefs are socially constructed" (Marshall \& Rossman, 2011, p. 149), I also led two focus group interviews - one with the focal students from each class. All of the individual and focus groups interviews were audio recorded and transcribed (see Appendix A for a complete schedule of teacher and student interviews).

Teacher interviews. I used a series of three semi-structured teacher interviews to investigate the teachers' perceptions of their students and self-reported approaches toward meeting the needs of their students (see Appendix B). The three interviews with each teacher ranged from 25 to 55 minutes in length. The first teacher interviews focused on the teachers' backgrounds and their purpose and approach to teaching U.S. history (Barton \& Levstik, 2004), as well as their perceptions of their students (Peck \& Herriot, 
2015). The second set of teacher interviews corresponded directly to the immigration unit; I asked the teachers to explain how they approach the topic of immigration and invited detailed explanation of their curriculum development and lesson planning processes. The final teacher interviews took place during December after I had been out of the field for approximately one month. These interviews allowed for member checking (Creswell, 2009; Marshall \& Rossman, 2011) as I invited the teachers' responses to selected fieldnote excerpts and initial findings that had emerged from the data.

Student interviews. I also conducted three interviews with the focal students. For the first and third interviews, I interviewed students individually to allow for an interpreter. For the second interview, I led a focus group interview with the focal students from each class in order to invite peer interaction (Marshall \& Rossman, 2011). For the individual interviews, I asked students whether they preferred to be interviewed in English or another language (Marshall \& Rossman, 2011). Marisol was the only students who expressed interest in having an interpreter, so I arranged for an SpanishEnglish interpreter as a means of facilitating Marisol's participation (Kvale, 2007; Williamson et al., 2011).

The first interview focused on asking students about themselves. I interviewed the focal students in Ms. Roger's class during the lunch period immediately following my classroom observation with interviews averaging 20 minutes. I interviewed the students in Mr. Mitchell's after his class during their elective period and these interviews lasted approximately 30 minutes each. I first presented students with a collection of 45 cards with descriptive terms. I asked students to select up to ten cards that would "best 
describe" or be "most important" to them (see Appendix C). The cards included a range of descriptors including personal interests (e.g., reader, activist) and background (e.g., Cuban, Tigrinya-speaker). Within each of the six groupings, I randomly sorted the cards in preparation for each interview and then presented the entire stack of cards to students without explaining their arrangement. Once the student selected his or her cards, I asked the student to explain each choice. I then sketched out a brief personal timeline based on student responses to a series of questions on their schooling and personal experiences. Finally, I asked the student questions about their perspectives on U.S. history, such as asking students to identify the three "most important" historical events and figures and then explain the significance of their choices (e.g., Epstein, 1998).

The second set of individual focal student interviews built on the first interviews and took place in December. I conducted all the final interviews during elective class time, which provided approximately 40 minutes for each student. I first asked students to again choose ten descriptor cards and followed up with the same questions about students' perspectives on U.S. history. As with the final teacher interviews, I then presented students with two selected excerpts from class observations and three emerging findings as a means of member checking (Creswell, 2009; Marshall \& Rossman, 2011). I presented each student with statements (a) and (b) identified in Figure 9 and then selected either (c) or (d) based on my observations of each student's class participation. I followed up with a series of prompts based on each statement similar to my semistructured questioning in response to the two fieldnote excerpts.

The second source of focal student data was a pair of student focus groups. Each focus group consisted of the focal students from each of the respective study classes so 
(a) One thing I have noticed is that many students talk about the history they learn in school as being important.

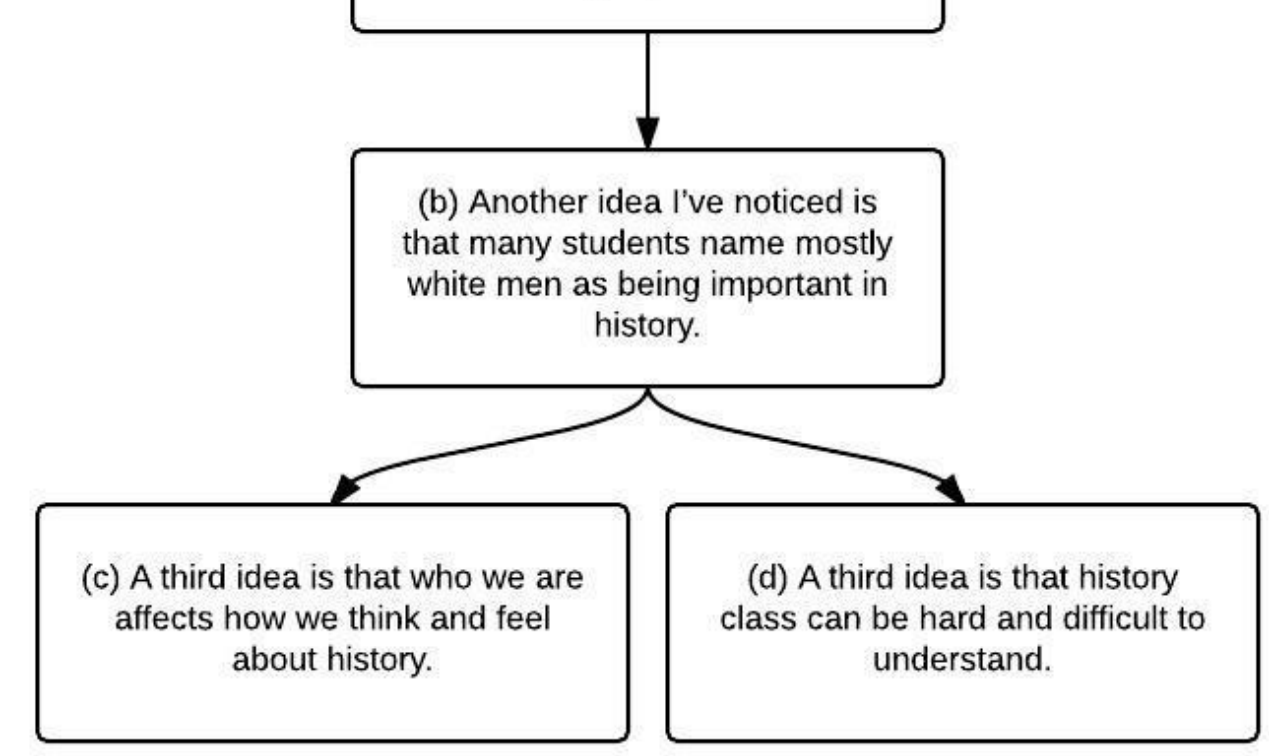

Figure 9. Emergent Findings Presented in Final Student Interviews

that students were able to discuss shared experiences (Marshall \& Rossman, 2011). The two focus group interviews averaged 35 minutes in length. For the primary prompt in each focus group, I asked students to jointly select 6 picture cards that represented the "most important" topics discussed in their immigration unit and then explain their selections (see Appendix B; adapted from Peck, 2010). This data was particularly useful in eliciting how students made sense of instruction on immigration, as well as accessing some of the shared meaning making incorporated by a sociocultural paradigm (Peck, 2010). The focus groups were conducted in English in order to include students with various linguistic backgrounds. 


\section{Data Analysis}

I based my data analysis procedures on Erickson's (1986) notions of analytic induction, in which the reading and coding of data includes "seeking disconfirming evidence as well as confirming evidence" (Erickson, 1986, p. 146) of emerging findings. The first phase of data analysis included preparation of analytic memos during the course of writing up fieldnotes and transcribing interviews during data collection (Creswell, 2009; Marshall \& Rossman, 2011; Silverman, 2005). I next read through the data as I collected it (Creswell, 2009), and wrote analytic memos in order to identify patterns (Erickson, 1986; Marshall \& Rossman, 2011). During this process I made notes on the fieldnotes and transcripts as I generated and applied both theory-generated bucket codes and axial codes (Coffey \& Atkinson, 1996; Marshall \& Rossman, 2011). I then sorted excerpts from the fieldnotes and transcripts into separate word processing files and subsequently organized each based on emergent themes. I conducted these processes concurrent with the fieldwork (Creswell, 2009), seeking emic perspectives and developing a refined coding scheme (Coffey \& Atkinson, 1996; Marshall \& Rossman, 2011).

At the conclusion of the fieldwork in early November, I continued with data analysis and prepared fieldnote excerpts for participant review during the final round of interviews. Focal student and teacher analysis of these excerpts during the December interviews were significant data sources in eliciting emic perspectives (Marshall \& Rossman, 2011), particularly regarding how students make sense of U.S. history and the enacted curriculum. These final interviews were instrumental in refining the coding and guiding the data analysis. 
Table 7

Sources of Student Characteristic Data

\begin{tabular}{ll}
\hline \multicolumn{1}{c}{ Student Characteristic } & \multicolumn{1}{c}{ Data Source } \\
\hline English language proficiency & Archival data (WIDA score) \\
Country of origin & Archival data and student interview \\
Gender & Student interview (optional) \\
Native/first language & Archival data and student interview \\
Race/ethnicity & Student interview (optional) \\
Religion & Student interview (optional) \\
Refugee status & Archival data \\
Standardized test scores and grades from & Archival data \\
previous year & \\
Years in U.S. schools & Archival data \\
\hline
\end{tabular}

After the final interviews in December, I continued analyzing the data through the application of both theory-generated and in vivo codes (Creswell, 2009; Marshall \& Rossman, 2011). Table 7 depicts the various theory-generated categories pertaining to student characteristics and the corresponding data sources for each. The items marked as "optional" in the student interviews reflect characteristics included in the card selection process that students may or may not have selected (see student interview protocol in Appendix B). At this point I "moved from coding to interpretation, which involved playing with and exploring the codes and categories that had been created" (Coffey \& Atkinson, 1996, p. 46). This iterative process involved checking and rechecking the data for evidentiary warrant with a particular focus on both individual students and cross-case analysis comparing different students. The result includes a qualitative narrative that addresses the research questions through reporting a combination of themes and description as found in the context of the bounded cases. 


\section{Researcher as Instrument}

Central to an interpretivist research design is an understanding of the researcher as instrument (Creswell, 2009; Flyvbjerg, 2001). In the present study, a number of aspects of my identity or "identities" may be considered particularly salient (Norton \& Early, 2011). I am a monolingual, White male. I was born a U.S. citizen in Kentucky. I have been a teacher, a graduate student and a researcher. In the following section I describe additional aspects of my identity that shaped my engagement in the present study.

In addition to being a monolingual, White male, I am also a Mennonite. In their description of Lao immigrants moving into a largely Mennonite community in Minnesota, Manke and Keller (2006) wrote that "Mennonites are less separated from the world than their distant Anabaptist relatives, the Amish. Yet they resist a consumerist, commodified American society and the politics of today's America" (p. 137). The authors further argued that the sense of "marginalization" that the longstanding Mennonite residents in the study felt brought them closer to the Lao newcomers, leading to exchanges of hospitality at the community and individual level. Their research strikes a chord for me, as I consider how my own Mennonite heritage and faith influence my positionality. An important aspect of this has been numerous international study and service trips, including a semester studying abroad as part of Eastern Mennonite University’s Cross-Cultural program (see also K. L. Anderson, 2013). I have traveled and learned about history, social justice, and diverse cultures. I have experienced what it means to work alongside fellow Christians in teaching Bible school or building a house. These experiences have confirmed my commitment to service and first led me to consider studying to teach English as a Second Language. 
As an educator and a researcher, my focus has been on teaching history and language as a means of helping students understand the world around them. As a classroom teacher, I have worked in a high school newcomer intensive English program and as a middle school social studies teacher. My experiences in these settings led to many of the questions that guide my research, including the research questions for the present study.

As a classroom teacher of many emergent bilinguals, I observed many of the challenges that teachers face in making the curriculum accessible and helping students to be successful. My empirical research thus far has primarily built on teacher perspectives, including an action research study while still in the classroom (Yoder, 2013) and a pair of case studies involving middle school U.S. history teachers (Yoder, Kibler, Futch Ehrlich, \& Molloy Elreda, 2015; Yoder \& van Hover, 2015). I have also participated in research on interactions between emergent bilinguals and their English-only peers and teachers (e.g., Kibler et al., 2015). This work has highlighted the need for student perspectives in the teaching and learning of history, leading to the research questions that guided the present study.

My multiple identities (Norton \& Early, 2011), including my positionality as a Mennonite, a teacher, and a researcher frame my sense making and inform my approach to the research questions (Flyvbjerg, 2001; Marshall \& Rossman, 2011). For example, I place a high value on history and my own identity is strongly connected to my Mennonite roots, which might be understood as both ethnic and religious in many ways. As a result I am interested in how other people experience and negotiate ethnic identity. Reflective of my own experiences as a teacher and many years as a student, I value education, which 
may cause me to overemphasize the role of schools in addressing big questions. Finally, as a researcher I recognize that I serve an important gatekeeping role and that my own monolingualism and insider status at the Garden View schools impact how I collected and analyzed the data (Flyvbjerg, 2001; Marshall \& Rossman, 2011). In the following section I describe the approaches I took to address these challenges and limitations.

\section{Criteria for Trustworthiness}

I employed an iterative approach to data analysis in an attempt to avoid what Erickson (1986) terms "the problem of premature typification" (p. 144). I subsequently grounded my conclusions in the data and used the final interviews at the close of the study to present the participants with evidence to elicit their sense making based on emerging themes and the data itself (Erickson, 1986; Krefting, 1999). I also offered the transcripts or notes from prior interviews to the participant teachers for member checking (Krefting, 1999; Marshall \& Rossman, 2011). I maintained a methodological log with notes on decisions made in the field and influential conversations and readings (Casanave, 2009; Silverman, 2005). I also wrote a series of analytic memos (Erickson, 1986; Marshall \& Rossman, 2011). These memos documented initial understandings from the data. The log and memos also serve as an audit trail for my fieldwork (Krefting, 1999).

Erickson (1986) names the following five threats to validity: (1) inadequate amounts of evidence, (2) inadequate variety in kinds of evidence, (3) faulty interpretive status of evidence, (4) inadequate disconfirming evidence, and (5) inadequate discrepant case analysis. I have acknowledged the limitation of limited evidence above; however, the primary concern here is that empirical assertions must be limited to the evidentiary 
corpus and thus I crafted my assertions in both scope and level of inference accordingly. In addressing the criterion of inclusion of variety of kinds of evidence, I followed Erickson's (1986) suggestion of allowing for triangulation of data through gathering multiple sources (e.g., interview, observation, and document analysis). My role as a partial insider helped with building bridges of trust that informed my understandings and lessened the likelihood of misinterpretation. Similarly, my familiarity with the setting provided insights into the kinds of discomfirming evidence needed in the assessment of assertions. Finally, I intentionally sought out two unique classes to aid in cross-class comparisons in order to elucidate potential differences in the aim of sensitizing my analysis to discrepant cases.

\section{Chapter Summary}

In the preceding chapter, I have outlined the methodology and methods for the present study. Building on the sociocultural theory described in chapter two, I have detailed an interpretivist research approach that best addressed the research questions guiding the study. These methods build on Erickson's (1986) criteria for trustworthiness. In the following chapter I describe the findings that resulted from carrying out these plans. 


\section{CHAPTER IV}

\section{FINDINGS}

The purpose of this study was to examine the historical perspectives of eleven middle school emergent bilingual and bilingual students. A review of the literature suggests that students' social positionality mediates their perspectives on U.S. history (e.g., Barton \& Avery, 2016; Epstein, 2009; Peck, 2010). Analysis of this body of knowledge led to the following research questions for the present study:

- How do middle school emergent bilingual and bilingual students describe their perspectives on U.S. history?

- How do various student characteristics (e.g., English language proficiency, country of origin) interact with middle school emergent bilingual and bilingual students' perspectives on U.S. history?

Data analysis from this qualitative multiple case study indicates that formal history instruction served as the primary mediator of the participants' historical perspectives as students identified historical actors and events that reflected the official U.S. history curriculum. When answering individual interview questions the participants' responses rarely deviated from content included in the Virginia history standards. However, three themes or schematic narrative templates (Barton \& Levstik, 2004; Carretero \& van Alphen, 2014; Peck, 2010; Wertsch, 2000; Wills, 2011) emerged from data analysis of students' historical perspectives. The first, most prevalent 
narrative, which I refer to as "the nation-building narrative," focused on notions of progress and development. The second and third narratives were closely related. Using what I have termed "the equality narrative," students described the concepts of rights and freedom as central to U.S. history. When employing "the discrimination narrative," students identified the concept of inequality as a major component of their historical perspectives.

Data analysis further suggests that when the official U.S. history curriculum conflicted with the participants' individual experiences and social identities, the students responded in one of two ways. In response to most classroom instruction and recalloriented interview questions, students appeared to silence their own experiences or discount their unique social identities, and instead privileged the official U.S. history curriculum. However, in some instances - typically in situations that allowed for more peer interactions - students referenced current events or their own backgrounds when they addressed historical perspectives that went beyond the "nation-building narrative." During these student-initiated classroom and focus group interactions, participants employed "the discrimination narrative" or "the equality narrative" as a bridge between the official curriculum and their own historical perspectives. In these cases, aspects of students' identity (i.e., race or ethnicity, national origin, gender, or religion) served as secondary mediators in students' historical perspectives, particularly in regards to which narratives participants employed and how they positioned themselves in relationship to their social context. By comparison, the interaction between students' schooling and language learning most often served to emphasize the official curriculum. 
Student Characteristics Overview

Emergent Narratives in U.S. History

The Nation-Building Narrative

"Started Building Stuff and Expanding": Events that Shaped the Nation

"America Was Made by a Couple of People": Important Historical Figures

"Because People Did This for Us": Progress and Change

The Equality Narrative

"Not Treated Bad, Treated Good": Establishing the Standard of Equal

Rights

"They Were Trying to Fix the World": Conceptualizing Freedom

"I Have a Dream": Understanding Rights as the Pursuit of Equality

The Discrimination Narrative

"Blacks Were Being Treated Really Bad": Defining Discrimination

"We Took Their Land": Identifying Discrimination in U.S. History

"He Is Pretty Much Like Hitler": Comparing the Past and Present

Interaction between Student Characteristics and Historical Perspectives

Schooling

"Everything So I Could Be Ready": History as Academic Subject

"I Guess They Have to Be Important for Us to Learn About Them":

Credible Sources of Historical Knowledge

"Earlier, In Other Grades": Standards of Learning

Language Learning

"Bilingual-I Speak Spanish and English": Participant Linguistic

Characteristics

"I Don’t Like History a Lot": Student Perceptions of History

"It's Like a Piece of Cake": Historical Misconceptions

Social Context

Racial and Ethnic Identity

"That's Racist!" Racism and Discrimination

"You Speak Mexican": Language and Ethnic Identity

"It's Like Black and White": Perspectives on Historical Racism

National Origin

"He's Born Here So He's From Here": Place and Identity

"People Don't Want Syrian Refugees": Contemporary Perspectives on Immigration

Gender

“They Didn't Just Appear": Perspectives on Historical Immigration

Religion

Participant Cases

"I'm Half Mexican": The Case of Felix

"I Would Be a Slave": The Case of Maria

"I Don't Like the American": The Case of Yonas

Chapter Summary

Figure 10. Overview of Chapter IV 
To explore these findings, I first describe the eleven students who participated as case study students in the present study. I next present findings from my analysis of "the assumptions, knowledge, and values" that guided the participants" "judgments about the meaning and significance of historical actors, events, institutions, and processes" (Epstein, 1998, p. 398), beginning with the narrative templates that emerged from my cross-case analysis of participants' historical perspectives. I then examine the interactions between student characteristics and the participants' historical perspectives. Figure 10 provides a complete overview of the chapter.

\section{Student Characteristics Overview}

In the first section of the chapter I describe the participants. The eleven students in the present study reflected the diversity found within the Garden View school district. Seven of the students speak Spanish, while other students named Arabic, Kurdish, or Tigrinya as their first language (see Table 8 for a detailed demographic description). Among the six students born in the United States, three identified family roots in Mexico, two in Honduras, and one in Iraq. The other five students were immigrants who were born in El Salvador, Eritrea, Ethiopia, Mexico, or Iraq. Among the immigrant students, three moved to the United States within the two years prior to this study. One student, Javier, described being born in Jamaica Hospital in New York City and beginning school in the United States before moving to Honduras for three years in elementary school (interview, 9/14/15). 
Table 8

Participant Student Demographic Data

\begin{tabular}{|c|c|c|c|c|c|}
\hline Pseudonym & $\begin{array}{l}\text { WIDA } \\
\text { Level }\end{array}$ & $\begin{array}{c}\text { First } \\
\text { Language }\end{array}$ & $\begin{array}{l}\text { Country of } \\
\text { Birth/ Family } \\
\text { Origin }\end{array}$ & $\begin{array}{l}\text { Years in } \\
\text { U.S. } \\
\text { Schools }\end{array}$ & $\begin{array}{c}\text { 6th grade } \\
\text { Reading SOL }\end{array}$ \\
\hline $\operatorname{Aras}^{b}$ & $6 \mathrm{~B}$ & Kurdish & U.S./Iraq & 7 & 357 \\
\hline Felix $^{b}$ & 4 & Spanish & U.S./Mexico & 7 & 374 \\
\hline Gebre $^{b}$ & $6 \mathrm{C}$ & Tigrinya & Ethiopia $^{c}$ & 7 & 386 \\
\hline Isabel $^{\mathrm{a}}$ & $6 \mathrm{C}$ & Spanish & U.S./Mexico & 7 & 448 \\
\hline Javier $^{\mathrm{a}}$ & 3 & Spanish & $\begin{array}{c}\text { U.S./ } \\
\text { Honduras }\end{array}$ & 5 & 308 \\
\hline Maria $^{\mathrm{a}}$ & $6 \mathrm{C}$ & $\begin{array}{l}\text { Spanish/ } \\
\text { English }\end{array}$ & $\begin{array}{c}\text { U.S./ } \\
\text { Honduras }\end{array}$ & 8 & 439 \\
\hline Marisol $^{\mathrm{a}}$ & 2 & Spanish & El Salvador & 1 & $\mathrm{n} / \mathrm{a}$ \\
\hline Santiago $^{b}$ & $6 C$ & Spanish & Mexico & 6 & 466 \\
\hline Salvador $^{\mathrm{b}}$ & $6 C$ & $\begin{array}{l}\text { English/ } \\
\text { Spanish }\end{array}$ & U.S./Mexico & 7 & 457 \\
\hline Yonas $^{\mathrm{a}}$ & 3 & Tigrinya & Eritrea $^{c}$ & 2 & 286 \\
\hline Yousuf $^{\mathrm{a}}$ & 3 & Arabic & Iraq & 2 & 278 \\
\hline \multicolumn{6}{|c|}{$\begin{array}{l}\text { Note. WIDA scores reflect English language proficiency on a scale of 1-6 with a label of } \\
6 \mathrm{~B} \text { or } 6 \mathrm{C} \text { signifying students who had "exited" the ESL program two years or more than }\end{array}$} \\
\hline \multicolumn{6}{|c|}{ two years ago, respectively. The state standardized reading test has a maximum score of } \\
\hline \multicolumn{6}{|c|}{ 600. The lowest passing score is a 400 while a score of 500 or above is a pass advance. } \\
\hline${ }^{\mathrm{a}}$ Student in $\mathrm{N}$ & itchell' & ${ }^{\mathrm{b}}$ Studen & Ms. Rogers' cla & ${ }^{\mathrm{c}}$ Studeı & with refugee \\
\hline
\end{tabular}


The educational profiles of the students reflect the diversity in their lived experiences. Five of the eleven students were classified as emergent bilinguals based on their WIDA language proficiency test results. Three of these students-Marisol, Yonas, and Yousuf - had moved to the United States within the past two years. The other twoJavier and Felix — were born in the United States and had attended U.S. schools for five and seven years, respectively. The other six students in this study had previously "exited" the ESL program in Garden View when they received a level 6 score on their WIDA assessments of English language proficiency. Among these bilingual students four received a passing score on their state-mandated sixth grade reading Standards of Learning (SOL) test.

In addition to gathering the demographic information detailed above, I invited students to select from 45 descriptor cards during each student interview (see Appendix C). While many of the self-identification descriptors provided demographic data, other terms denoted less formal aspects of identity and interests (see Appendix D). Using these cards, students frequently selected terms that identified their relationships, hobbies, and gender. Students also identified concepts of nationality and language status in their selections. I examine participants' selections in more detail later in the chapter.

In addition to eliciting student perspectives through interviews, I also observed the participants in Ms. Rogers' and Mr. Mitchell's seventh grade U.S. history classes. I found that students in Ms. Roger's morning class often engaged in whole class lecturebased activities and then worked quietly on independent seat work. In Table 9 I present brief descriptions of the five case study students in Ms. Roger's class. These observations and reflections connote the various roles students played in the classroom. 
For example, I routinely noted Santiago's "expert" status as a student who often

volunteered to answer questions in a whole class setting, while Aras primarily engaged

peers in social conversation (analytic memos, 9/13/15, 2/12/16).

Table 9

Case Study Students in Ms. Rogers' Class

\begin{tabular}{|c|c|}
\hline Student & Description \\
\hline Aras & $\begin{array}{l}\text { Aras was the only Kurdish speaker in this class. While he only spoke up } \\
\text { in class occasionally, he was interestingly redirected for talking with } \\
\text { [two Black or biracial native English speakers] on a couple occasions. } \\
\text { There were few case study students who regularly talked with their } \\
\text { native English speaking peers, so this interaction stands out. Aras was } \\
\text { labeled as a Level 6B. In his first interview, the first card Aras selected } \\
\text { was "English-speaker," which he linked to location in his explanation: "I } \\
\text { picked English because I was born here and I learned English in school. } \\
\text { Kurdish, my parents speak Kurdish so I learned too. My religion is } \\
\text { Muslim. I was born here so I'm American." Aras clearly linked speaking } \\
\text { English and being born "here"- -both of which he applied to his own } \\
\text { experience- to being "American." Aras' analysis of historical } \\
\text { significance captured the broad themes his peers also identified: nation- } \\
\text { building set the stage with George Washington-coupled with Thomas } \\
\text { Jefferson, in Aras' case-as the first key figure. Then Aras identified } \\
\text { Martin Luther King third because "Whites and Blacks had to be separate } \\
\text { and so he tried to change that." Aras' identification of the KKK as a } \\
\text { "surprising" thing he'd learned fits with his expectation of progress and } \\
\text { resolution. The identification of a simple narrative seemed to be the } \\
\text { primary marker of the "easy" history Aras encountered at school as } \\
\text { compared to the "complicated" history he learned at home, in which } \\
\text { "some of the stuff is missing..." as compared to school where "they put } \\
\text { in little details that you should know about." In his second interview, } \\
\text { Aras said the United States was "built by a couple people" and then } \\
\text { detailed a number of examples of discrimination. Later he suggested that } \\
\text { some online sources "might be fake," contrasting them to the relative } \\
\text { trustworthiness of "a teacher or a textbook or something." At the close } \\
\text { of our second interview, Aras stated that "there's still a lot of racist } \\
\text { people." When he argued that terrorists do not represent what it means to } \\
\text { be Muslim, he concluded that "Muslim means peace." }\end{array}$ \\
\hline Felix & $\begin{array}{l}\text { Felix was the only emergent bilingual from Ms. Roger's class who } \\
\text { consented to be in the study. He was often rather quiet in class, though } \\
\text { his occasional contributions suggested he understood Ms. Roger's } \\
\text { instruction. Overall, Felix was a conscientious student. He regularly } \\
\text { asked Ms. Rogers questions and volunteered to read. His explanation of }\end{array}$ \\
\hline
\end{tabular}


his descriptor cards revealed a unique interpretation of nationality: "Mexican, my Dad is and my Mom is Mexican. So I'm half Mexican. American because I was born here. I was born in... raised in Virginia." In his discussion of history, Felix provided answers that align closely with the official curriculum and notions of nation-building and rights. One outlier was his comment about reading library books about the history of Mexico. While Felix identified himself as American, his description of class discussions on the topic of "tolerance" seems to indicate he was on the receiving end of racism or intolerant behavior. As such, tolerance seemed like more of a shaming concept rather than an empowering one. For example, Felix defined tolerance as "like when somebody is being racist to you, you don't really care." Felix said he would like to learn about Latinos in U.S. history, but had not in the past, which he explained through the following statement: "I don't think they really did much."

Gebre Gebre was often very attentive and earnest in his classroom contributions. The only speaker of Tigrinya in the class, Gebre reported liking English because of the doors it opens even as he recognized the challenges he faced in learning his Ethiopian heritage languages. Gebre explained that he is a Christian because "My mom told me she loves God and all of those things and I do, too." The complexity of these relationships became clearer as Gebre stated that he "was born in Garden View, but I'm African." In his case, the broader term "African" served as an umbrella. When asked to clarify, Gebre stated: "I don't really know, because my mom was born in Eritrea and my dad was born in Ethiopia, so I'm both." Later Gebre mentioned that he did not "learn about that much history about stuff [at home] because my mom and dad have work. They don't come until late at night." Gebre was often quite expressive. For example, he described picking the tenor saxophone for its "amazing sound." He cautioned against making generalizations about people during the interviews, including talking about how the Paris attacks served to paint Syrian refugees in a bad light. He concluded, "Not all people are the same of the same race." Overall, Gebre focused on a progressive narrative both in terms of technology helping to make the world what it is today and in direct connection to discrimination decreasing and rights increasing.

Salvador Salvador was the only student who had English identified as both the preferred oral and written language at home. Salvador was often attentive in class and regularly answered Ms. Rogers' questions in detail. Salvador seemed much more active in academic interaction in the first month or so of observations and then did not stand out as being as verbally engaged later in the semester. In our first interview he identified himself as American explaining, "I was from Virginia." He said English "was my first language" and then added that he also speaks Spanish, having "learned them at the same time." Salvador used first person language (i.e., "He was the father of our nation...") when discussing U.S. history. In the second interview I asked him to clarify 
this language in the context of saying "We forced [Indians] off their land." Salvador explained "we" in that context meant "the British." Santiago Santiago was very active in class and Ms. Rogers seemed to call on him at times when no other students volunteered. He was the only one of Ms. Rogers' consented students who had straight A's during the prior school year. During the first interview Santiago talked about where he is from: "Mexican because that's where I was born. Immigrant because I came from Mexico to the United States. Gamer because I like to play a lot of PS4 and bilingual because I speak 2 languages." When Santiago nominated three historical figures in September, his answers were closely aligned with recent instruction. In fact, Santiago explained his responses by stating: "That's what we learned about today." While Santiago seemed to outsource the historical significance question to the "knowledge holding" teacher when it came to historical figures, he very clearly chose the theme of rights - both the exclusion and restoration of rights - when discussing important historical events. In this second interview, Santiago appeared to be using simple name recognition when he named George Washington because "he was the first president," but stated that he did not "really know too many other people."

Distinct behavior patterns marked the classroom interactions of the six case study students in Mr. Mitchell's class. Emergent bilinguals Javier and Yonas walked around the room and joked with peers on a daily basis. In response, Mr. Mitchell often verbally reprimanded them or glared at them from the front of the room when they left their assigned desks. By contrast, Yousuf and Marisol, the other two emergent bilingual case study students, rarely addressed Mr. Mitchell in a whole class setting, instead working individually or asking questions during independent work time. Among the bilingual case study students, in whole class settings, Maria answered Mr. Mitchell's contentrelated questions on a daily basis, while Isabel regularly sat quietly during instruction and only talked with peers during small group activities. In Table 10 I provide a brief description of each case study student in Mr. Mitchell's class (analytic memos, 9/13/15, 2/12/16). 
Table 10

Case Study Students in Mr. Mitchell's Class

\begin{tabular}{|c|c|}
\hline Student & Description \\
\hline Isabel & $\begin{array}{l}\text { Isabel appeared to be engaged in class most of the time; however, she } \\
\text { was quick to engage socially with small groups of peers. She sat by } \\
\text { Maria at the beginning of the semester and seemed to know her well, as } \\
\text { evidenced by Maria doing her hair on September 4. Isabel was also very } \\
\text { conscientious in her interactions, as when she apologized to me after } \\
\text { class one day after the pencil eraser she threw bounced against the wall } \\
\text { near my seat. Isabel's academic work reflected her Level 6C status. Her } \\
\text { geography poster project revealed that she was able to correctly apply } \\
\text { Mr. Mitchell's sentence frames and write in complete sentences without } \\
\text { noticeable errors. During the first interview, Isabel chose primarily } \\
\text { relational (i.e., sister, friend) and personal interest (i.e., reader, musician) } \\
\text { descriptors. The primary exception was that she chose "bilingual," } \\
\text { adding "I speak Spanish and English." Later in the interview Isabel } \\
\text { explained that while they speak both "Spanish and English" at home, her } \\
\text { family spoke "mainly English cuz my mom's trying to learn it." Isabel } \\
\text { described being born in Tampa, Florida and then beginning school in } \\
\text { Louisiana. She said she did not "think" she had lived in Mexico, though } \\
\text { she recalled visiting her grandma there. In the second interview, Isabel } \\
\text { described speaking both Spanish and English, but noted that she is an } \\
\text { "English speaker because I started learning in kindergarten." She added } \\
\text { that she is Christian "because...I think I'm a Christian. I forgot which } \\
\text { one we were." Isabel described herself as both "Caucasian because I'm } \\
\text { originally from here..." and "American because I've lived here and I've } \\
\text { gotten used to being here." She also said, "I'm Mexican because that's } \\
\text { where my origin is from." Isabel also repeated many of the terms she } \\
\text { picked in the first interview, including daughter and musician. Isabel } \\
\text { explained her selection of "feminist"- "because I believe women should } \\
\text { have equal rights"-and "environmentalist"-_because I think we should } \\
\text { take care of the world more"-as based on her beliefs. In total, she } \\
\text { selected } 18 \text { cards for the second interview, adding the more social group- } \\
\text { oriented terms around language, religion and ethnicity. }\end{array}$ \\
\hline Javier & $\begin{array}{l}\text { Javier was a class clown through and through. He yelled out in class, } \\
\text { trying to make his classmates or Mr. Mitchell laugh. His comments often } \\
\text { had to do with "chocolate" and concepts around skin color. During his } \\
\text { first interview, he spoke openly about the role his mom plays in his life } \\
\text { given that he did not know his dad, as well as the fact that he spoke } \\
\text { Spanish at home- "I came from Honduras"-and English at school. He } \\
\text { later explained that he spoke English with his older sister who is in high } \\
\text { school and that his brother in first grade was learning English so Javier }\end{array}$ \\
\hline
\end{tabular}


spoke both English and Spanish to him. In class Javier was often the first one to speak English when there was a group of students speaking Spanish together. In discussing historical figures, Javier's comments ranged from detailed fact recall to significant misconceptions. At one point he said he could not think of a third historical figure, but then identified Jefferson as the third president and the author of Declaration of Independence, explaining, "If it wasn't for him we would have still had a lot of tea taxes and paper taxes." In telling the story of "Robin Hook" and then Thomas Edison during his second interview, Javier demonstrated misconceptions as he appeared to integrate isolated facts into a cohesive personal narrative. Javier occasionally changed his answers, interweaving numerous misconceptions in his attempt to provide a narrative for each historical figure. This was a common thread in Javier's discussion of history. Javier also frequently stated "I forgot" when asked to explain or elaborate on a response.

Maria Maria was a very social and loud young lady. She often talked in class, at times talking to herself, the girls around her, or exchanging verbal jabs with BA [a Latino boy]. Maria routinely spoke in English, though she also spoke Spanish in class on occasion, most frequently with Marisol or other students with lower WIDA levels. Maria's geography poster project included the information Mr. Mitchell assigned. However, Maria listed facts rather than using the sentence frames. Her reflection aligns with her classroom behavior as she wrote that "talking and distraction" were her biggest obstacles. This social awareness carried over into discussions of content, such as when she asked Mr. Mitchell when color photographs were created or when she talked about skin color. Maria often volunteered to answer questions and occasionally openly pontificated in class. In general, Mr. Mitchell was patient with her and sometimes encouraged her elaborations through asking her to continue or shutting down other students who scolded her for taking too long. Maria was one of the few students who selected the "English learner" descriptor card explaining: "I picked English learner because I learn English very easily and I read very good." Maria's explanation of nationality was also multifaceted, as she explained that Cuban was "part of my heritage" through her step-father, while her mom was Honduran and Maria was American- "I was born in this country." After Maria explained that her step-dad was not an immigrant "because he came from Cuba in a boat," I had to wonder if being an "immigrant" signified a lack of documentation for Maria. Maria spoke at length about what heritage means to her and how she follows the "religion" and celebrations of Honduras. My interviews with Maria were marked with early adolescent pizzazz and humor as she joked about her mom and Lebron James being the most important people in U.S. history.

Marisol Marisol was the only student who selected a language other than English for the interview on her consent form. Marisol often spoke to her peers in Spanish during class and her WIDA level was a 2. Marisol most often 
talked to BG and Miguel [both Spanish-speaking emergent bilinguals], though she also hung around BA's desk later in the semester. Marisol's acknowledgement that the poster was the "primera vez/first time" she did homework was telling, though I had to wonder why she chose to complete the project. Perhaps the pictures helped to make it feel more doable, though I noticed Yousuf drawing one of her pictures for her. Her project ended up with many grammatical errors and on her reflection she wrote that "not enough into [sic]" was the biggest obstacle. I assume she meant "info." Either way, it appears that language was a major mediator in how Marisol makes sense of history content. Both of our interviews were conducted in English and Spanish with an interpreter. During the first interview, she described liking to "play with words" in Spanish and reported learning some French from her aunt as a young child. She suggested that her teachers may describe her as talking a lot in class. Marisol reported that she has not had a history class in the past during her prior schooling in El Salvador. Marisol's family moved during the study and on November 4, 2015 she transferred to Garden View Middle School.

Yonas Yonas was extremely talkative. He often came across as somewhat immature as he sort of bounced around at times and called out silly comments. He was the only Tigrinya-speaker in the class. Yonas chose the word "African American" in his first interview, but then explained that he had learned about African Americans: "Because...I watching in Mr. Mitchell's class - the bad people - the African American, they make them do anything they want...cuz that makes me sad a lot of time." He also chose "Kurdish-speaker" because "I want to learn Kurdish" and then contrasted this to Tigrinya: "I know how to speak my language... a lot." His other cards appeared to be a mix between concepts he had an affinity for (i.e., "Salvador...They make good pupusa") and those that described him (i.e., "Eritrea...this is my favorite - is MY country though and I like it"). His selection of the "Muslim" card appeared to be inadvertent as he explained that he "HATES" Muslims "because they mean, some of them..." Yonas reported being born in Eritrea, which is also where he started school. He explained that his maternal grandmother taught him Arabic though he speaks Tigrinya with most of his family. Speaking of his seven-year-old brother, Yonas explained, "sometime he don't understand Tigrinya, we talk English to him." Yonas described starting school in Garden View two years before this study, first in the newcomer program at the school across town and then switching to his current school last year. In a crazy twist during the second interview, Yonas claimed that his mom was from Eritrea and his dad was from Honduras. Clearly, Yonas was trying to fit in with his peers, most notably Javier who also had Honduran roots. Yonas' playful and growing use of Spanish over the course of the semester fits with his seemingly fluid or shifting identity. Yonas similarly integrated ideas from history instruction, including racism and the KKK, into his family stories. 
During this second interview, Yonas did create some distance between himself and Javier's racialized "chocolate" references. I noticed that when I used the terms White and Black, Yonas avoided both. Instead, Yonas said the term "Black" was racist and when discussing Obama, he identified Obama as "American" and "African" rather than White and Black.

Yousuf Yousuf was very quiet in class. Yousuf reported that "sometimes when I work by myself I think better." The observational data certainly demonstrated that he primarily worked alone in class, often playing an observer role within the classroom. Yousuf explained that "when it's easy for me or medium, I just work by myself." By comparison, he suggested he would seek out a peer to work with when he felt that questions were "hard...because I need some help," adding, "I could help them too." Overall, he was a very studious student who talked about wanting to do well and "learn everything" in order to be prepared for high school and college. Yousuf seemed to keep to himself, even when there was lots of social interaction taking place around him. He appeared to know some of the other students with lower WIDA levels, perhaps from being in newcomer classes with them. For example, I saw him help both Marisol and BG by drawing pictures for them on their posters. Yousuf was a very conscientious student. I noticed in the September 4 observation that he very faithfully carried out the directions to orally share with other students so that two of the boys would sign his paper. In his geography project reflection Yousuf wrote that the "hard words" presented the biggest issue so he had to "learn more" to overcome this obstacle. This kind of approach clarified Yousuf's initial focus as comprehension rather than analysis or critique when it came to school history.

In this section I have briefly described the eleven case study students from Ms. Rogers' and Mr. Mitchell's U.S. history classes. These descriptions provide an introduction to the experiences and perceptions of each student. In the following section I focus on the perspectives on U.S. history that the participants described.

\section{Emergent Narratives in U.S. History}

Data analysis revealed that while describing their historical perspectives on U.S. history the participants frequently incorporated aspects of three themes or schematic narratives templates (Barton \& Levstik, 2004; Carretero \& van Alphen, 2014; Peck, 
Table 11

Schematic Narrative Templates found within Participants' Historical Perspectives

\begin{tabular}{|c|c|c|}
\hline Narrative & Description & $\begin{array}{l}\text { Participants Employing } \\
\text { Narrative }\end{array}$ \\
\hline $\begin{array}{l}\text { Nation- } \\
\text { Building } \\
\text { Narrative }\end{array}$ & $\begin{array}{l}\text { The nation-building narrative centers } \\
\text { on notions of progress and } \\
\text { development. The founding of the } \\
\text { United States and historical events that } \\
\text { contributed to the formation and } \\
\text { preservation of the political structure } \\
\text { are central to this narrative. In the } \\
\text { nation-building narrative political } \\
\text { actors and institutions figure } \\
\text { prominently. In this narrative } \\
\text { template, students named Christopher } \\
\text { Columbus and George Washington as } \\
\text { important because they symbolize } \\
\text { European exploration and the } \\
\text { establishment of the United States, } \\
\text { respectively. }\end{array}$ & $\begin{array}{l}\text { Aras } \\
\text { Felix } \\
\text { Gebre } \\
\text { Isabel } \\
\text { Javier } \\
\text { Maria } \\
\text { Marisol } \\
\text { Salvador } \\
\text { Santiago } \\
\text { Yousuf }\end{array}$ \\
\hline $\begin{array}{l}\text { Equality } \\
\text { Narrative }\end{array}$ & $\begin{array}{l}\text { The equality narrative focuses on the } \\
\text { concepts of rights and freedom. In the } \\
\text { equality narrative historical figures and } \\
\text { people groups who helped others and } \\
\text { worked for equal rights take center } \\
\text { stage. In this narrative, students } \\
\text { credited Abraham Lincoln with ending } \\
\text { slavery and identified Martin Luther } \\
\text { King Jr. as an important civil rights } \\
\text { leader. }\end{array}$ & $\begin{array}{l}\text { Aras } \\
\text { Felix } \\
\text { Gebre } \\
\text { Isabel } \\
\text { Javier } \\
\text { Maria } \\
\text { Salvador } \\
\text { Santiago } \\
\text { Yonas } \\
\text { Yousuf }\end{array}$ \\
\hline $\begin{array}{l}\text { Discrimination } \\
\text { Narrative }\end{array}$ & $\begin{array}{l}\text { The discrimination narrative marks the } \\
\text { central role of inequality in students' } \\
\text { understanding of U.S. history. The } \\
\text { discrimination narrative is closely } \\
\text { linked to the equality narrative as } \\
\text { discrimination - frequently marked by } \\
\text { students' use of the term "racist"- } \\
\text { serves as the counterweight to the } \\
\text { presence of or struggle for equality. In } \\
\text { this narrative, students critiqued the Ku } \\
\text { Klux Klan and Donald Trump for } \\
\text { treating certain groups of people } \\
\text { unfairly. }\end{array}$ & $\begin{array}{l}\text { Aras } \\
\text { Felix } \\
\text { Gebre } \\
\text { Isabel } \\
\text { Javier } \\
\text { Maria } \\
\text { Salvador } \\
\text { Santiago } \\
\text { Yonas } \\
\text { Yousuf }\end{array}$ \\
\hline
\end{tabular}


2010; Wertsch, 2000; Wills, 2011). In this section of the chapter, I first describe the ways in which ten participants employed what I term "the nation-building narrative," which is built on notions of progress and development, order and institutions (see Table 11). In the nation-building narrative political actors and institutions figure prominently. I next present the participants' historical perspectives that built on "the equality narrative," comments that included attention to the concepts of rights and freedom. Ten students frequently utilized the equality narrative when they attributed historical significance to historical figures and people groups working for equal rights. I then examine students' descriptions of history that reflected what I term "the discrimination narrative," which marked the central role of inequality in the historical perspectives that ten students described. The discrimination narrative is closely linked to the equality narrative as discrimination — frequently marked by the term "racist"— served as a counterweight to the presence of or struggle for equality. In the following section, I present these narratives as a framing device in order to systematically examine the case study students' historical perspectives on U.S. history.

\section{The Nation-Building Narrative}

Ten of the eleven case study students employed the nation-building narrative when they described ways in which people, events and institutions in U.S. history contributed to the process of establishing and maintaining the country. The students frequently identified building or growing the United States as a marker of historical significance. For example, participants used the nation-building narrative to organize their arguments for why presidents and laws were important. 
In this section, I describe three specific elements of the nation-building narrative found within the data. The first is the concept of "building" the United States, starting with European settlers and the founding of the new nation. The second is the rationale participants provided when describing the importance of historical figures. The third is the notion of progress or change, which students articulated as a source of historical significance. Together these three components summarize the nation-building narrative as reflected in the students' historical perspectives. I close this section with a brief examination of Yonas, who was the only student who did not describe historical perspectives that reflected the nation-building narrative.

"Started building stuff and expanding": Events that shaped the nation. In their description of events that shaped U.S. history, the participants employed the nationbuilding narrative as they described the formation and growth of the United States. Santiago exemplified this component of the nation-building narrative when he provided the following summary of U.S. history: "They all came over here and started building stuff and expanding" (interview, 12/16/15). Santiago further explained his selection of Christopher Columbus' discovery of America, the writing of the Constitution and "the wars" as the three most important events in U.S. history:

Interviewer: What are the three most important events in United States history? Santiago: Probably when they first discovered America.

Interviewer: Who are they? Who discovered it?

Santiago: Christopher Columbus.

Interviewer: What's another important event? What's something else that happened?

Santiago: I think when they made the Constitution, they were all involved. Interviewer: How about as the third one?

Santiago: I don't know which one of the wars to say, but maybe the wars are really important. 
Interviewer: You have Columbus who discovered America, we have the Constitution, and we have wars. What about these things are important? Why are they important?

Santiago: Because Christopher Columbus, when he discovered America, he went back to Spain, and he told his people that he had discovered land, and they all came over here and started building stuff and expanding.

Interviewer: Why is the Constitution important?

Santiago: Because that's when they all got together, and they wrote the laws, and what we do in the United States, and what we can't do.

Interviewer: What about wars is important?

Santiago: I think it's important that the wars that we had were to protect the United States and make it what it is now. (interview, 12/16/15)

As Santiago provided his argument for the historical significance of each selection, he first emphasized the role of Columbus in beginning the process of European settlement in which, "they all came over here and started building stuff and expanding." Santiago's inclusion of the Constitution and the broader concept of "writing laws"-important because they provide clarity on "what we do in the United States, and what we don't do"- demonstrated the conceptual and institution-development elements of the nationbuilding narrative.

The participants also identified wars as important events in U.S. history because they demonstrated and extended the reach of the country. Six of the eleven participants identified the Civil War as the one of the most important events in U.S. history (see Table 12). Among these six case study students, Aras, Felix, and Salvador also nominated the Revolutionary War as important. In the interview excerpt above, Santiago explained his general reference to "the wars" as reflective of the need "to protect the United States" and linked to building "what it is now" (interview, 12/16/15). Isabel similarly explained the importance of military action, specifically "Indian Wars, the Civil War, and the Mexican and Texas War," as contributing to how "our nation got bigger" (interview, 9/10/15). In 
Table 12

Student Nominations for Most Important Events in U.S. History

\begin{tabular}{|c|c|c|}
\hline Historical Figure & $\begin{array}{c}\text { Student } \\
\text { Nominations }\end{array}$ & Sample Student Explanation \\
\hline Civil War & 6 & $\begin{array}{l}\text { "freedom"; "United States got back } \\
\text { together"; "we beat them"; "keep } \\
\text { things even between the states" }\end{array}$ \\
\hline $\begin{array}{l}\text { Fourth of July } \\
\text { (Independence Day) }\end{array}$ & 3 & $\begin{array}{l}\text { "Britain left Virginia alone and we } \\
\text { claimed our independence"; "they } \\
\text { remember all the soldiers that died in } \\
\text { the army"; "químicos que son luces } \\
\text { en el cielo/fireworks-chemicals } \\
\text { with lights in the sky" }\end{array}$ \\
\hline Revolutionary War & 3 & $\begin{array}{l}\text { "they didn't want to pay Europe } \\
\text { taxes"; } \\
\text { "made USA its own country"; "won } \\
\text { our independence" }\end{array}$ \\
\hline Columbus Exploration & 2 & $\begin{array}{l}\text { "discovered America"; "he saw the } \\
\text { United States" }\end{array}$ \\
\hline World Wars I \& II & 2 & $\begin{array}{l}\text { "World War I connected to World } \\
\text { War II"; "I don't know that much } \\
\text { about it, but I know that we won" }\end{array}$ \\
\hline
\end{tabular}

Note. Nominations reflect December interviews with eleven case study participants. No

other events were identified by more than one student.

her December interview, Isabel expanded on her summary, stating that "American Indian wars was $[s i c]$ when we started getting more new land, also pushing out the Indians, the Native Americans" (interview, 12/10/15). While Isabel's views on the problematic nature of this process are discussed later in this chapter, Isabel's conclusion that as a result of the conflicts "the United States got more land and more places to settle into" reflected the progress and expansion aspects of the nation-building narrative. Isabel also elaborated on the Civil War as demonstrating "how the union eventually always stays together" and the "Mexican and Texas War" as an example of "how our nation helped other states in trouble" (interview, 9/10/15). Within the nation-building narrative, war 
Table 13

Student Nominations for Most Important People in U.S. History

\begin{tabular}{lcl}
\hline \multicolumn{1}{c}{ Historical Figure } & $\begin{array}{c}\text { Number of Student } \\
\text { Nominations }\end{array}$ & \multicolumn{1}{c}{ Sample Student Explanation } \\
\hline George Washington & 11 & $\begin{array}{l}\text { "First president"; "Helped our } \\
\text { country"; }\end{array}$ \\
Abraham Lincoln & 7 & $\begin{array}{l}\text { "Stopped slavery"; "equal rights" } \\
\text { Martin Luther King, Jr. }\end{array}$ \\
"Be equal”; "Civil Rights"; "Black \\
Barack Obama & 4 & $\begin{array}{l}\text { History Month" } \\
\text { "President of the United States"; } \\
\text { "letting refugees in" }\end{array}$ \\
\hline
\end{tabular}

Note. Nominations reflect December interviews with eleven case study participants. No

other individuals were identified by more than one student.

provided physical expansion, as well as "protecting" and defining the character of the

nation. As students described the important events that shaped the formation and

expansion of the United States, they also identified key figures in U.S. history, such as

Christopher Columbus. I examine these characterizations in the following section.

“America was made by a couple of people": Important historical figures.

Participants also focused on the concept of important historical figures, a second element of the nation-building narrative. In each of the two interviews I conducted with the eleven participants, I asked them to nominate three "important people in U.S. history." While Javier, Marisol, and Yonas expressed difficulty naming events in U.S. history, all the students readily named historical characters. Aras made the centrality of individuals in the narration of U.S. history when he stated, "America was made by a couple of people" (interview, 12/9/15). This summary captured the sentiments of many students for whom names were clearly more salient than events. Table 13 depicts the most frequently nominated historical figures. While the theme of rights is clearly present and will be discussed in a subsequent section of this chapter, the high number of nominations 
George Washington received — and particularly the rationale students provided for nominating him — demonstrated the attribution of historical significance within a nationbuilding narrative.

During their interviews in December 2015, all eleven of the students identified George Washington as one of the top three most important people in U.S. history. While the convergence in students' responses was significant, the reasons for selecting Washington provided additional insights into the prevalence of the nation-building narrative. For example, Isabel focused on the formation of the United States when she called Washington the "father of our country" (interview, 9/10/15). When asked to explain why he selected Washington, Yousuf similarly said, in a manner-of-fact tone, "He was the first president" (interview, 9/9/15). In his interview, Santiago used the exact same words:

I think a really important person would be George Washington, maybe. He was the first president [emphasis added]. I don't really know too many other people... [We learned about George Washington] earlier, in other grades, but we haven't really in Miss Rogers' [class]. (interview, 12/16/15)

While Santiago's initial statement regarding Washington's historical significance may appear to be weakened by his use of the qualifier "maybe," the fact that Santiago was hesitant to name any other historical figures reinforces Washington's prominence. Marisol, the most recent immigrant to the United States among the participants, identified only George Washington in response to a question about important U.S. historical figures, before saying "I don't know" and declining to name any other significant historical figures:

Interviewer: Who are the three most important people in United States history? Interpreter: ¿Quiénes son las tres personas más importantes en la historia de los Estados Unidos? 


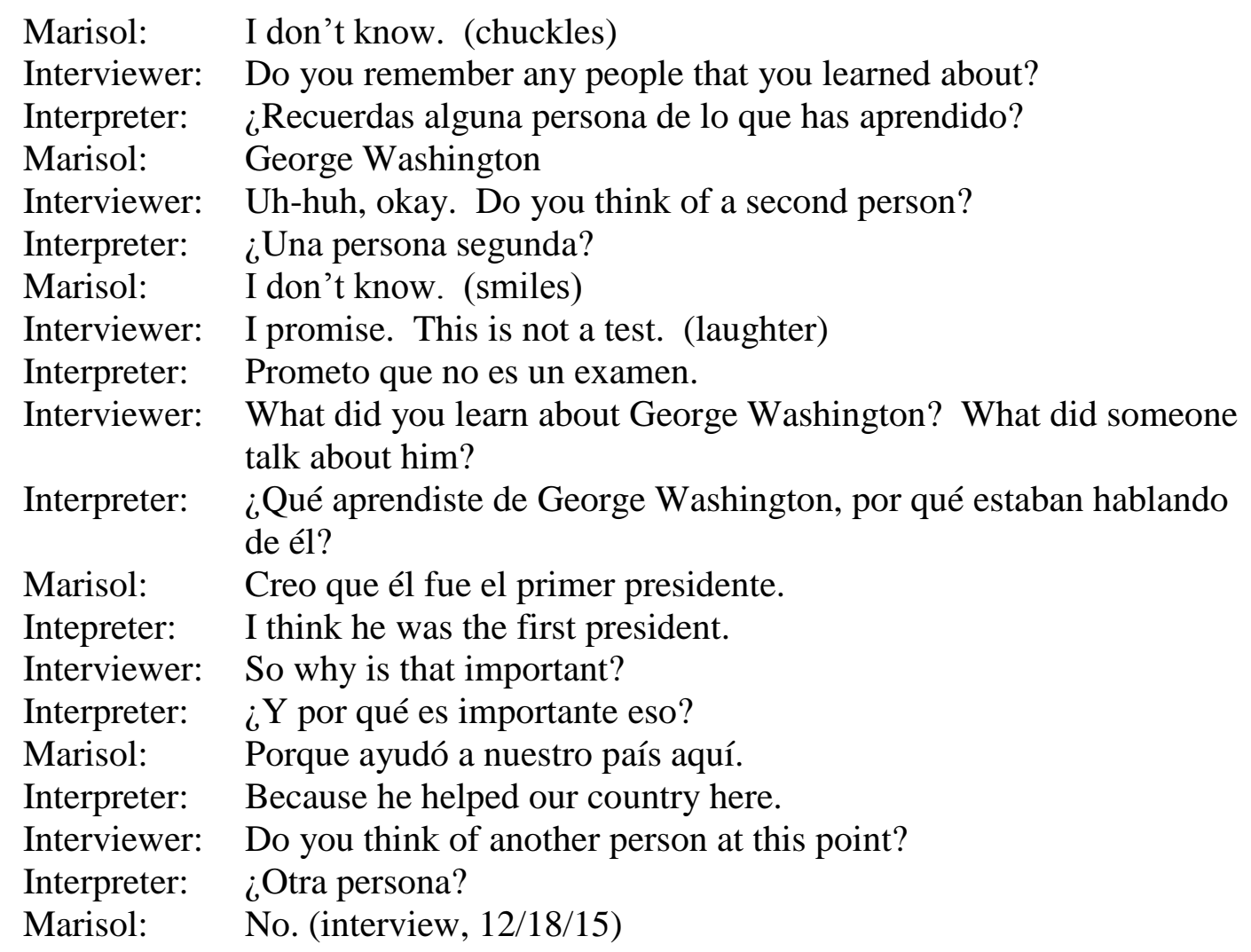

As in Santiago's case, Marisol's hesitance in naming another historical figure emphasized Washington's standing. Marisol stated that Washington was "el primer president/the first president" who was important because "ayudó a nuestro país aquí/he helped our country here." These instances in which George Washington was the only historical figure that students knew — coupled with the nomination of Washington by all eleven studentsprovided clarity on Washington's prominence as "the first president" and an important historical actor who "helped our country."

Abraham Lincoln was the only other historical figure that more than half of the participants nominated. When attributing historical significance to Lincoln, students focused primarily on his role in ending slavery or promoting unity. Maria characterized Lincoln's significance this way: “Abraham Lincoln was trying to stop slavery and get the Union and South back together so they wouldn't undo" (interview, 12/14/15). Lincoln's 
role in re-uniting the country mapped onto the nation-building narrative as students had also applied it to Washington. These statements demonstrated that students viewed presidents and statesmen as important when they were understood to have contributed to creating and preserving U.S. political institutions. In the following section I expand on the links between students' notions of progress and change and the nation-building narrative.

"Because people did this for us": Progress and change. Participants also employed a third component of the nation-building narrative - the concepts of progress and change - in their historical perspectives. In this element, students de-emphasized the nation-state and instead attributed historical significance based on change over time. Students' comments focused on contributions to their own lives and contemporary life in the United States. Gebre demonstrated this clearly in response to an open-ended question about how he made meaning of U.S. history:

I would say who the people are, what they did to make American what it is today...Like the telephone. People make the telephone. That's what America...People made video games. People make history. People can make history in all of those things and I would say they did good things because I like America how it is today because people did this for us (interview, 12/8/15).

For Gebre, the telephone and video games represented progress in a way that was unique to "America" as captured in his summarizing statement: "I like America how it is today because people did this for us" (interview, 12/8/15). This was a theme that appeared frequently during the focus group I led with the five male participants in Ms. Rogers' class. During the focus group, I asked the students to look through picture cards and select the six most important people, events or ideas from their recent unit on immigration and industrialization. As captured in the first turn in the excerpt below, 
Salvador described two of the picture cards the group had collectively selected. Salvador subsequently described criteria for how progress may be used as a concept against which historical significance may be assessed:

Salvador: Alexander Graham Bell-telephone and Thomas Edison when he improved the light bulb.

Interviewer: And let me ask Salvador for this one — why do you think those are important?

Salvador: The inventions...?

Interviewer: Mmhmm (affirmative)

Salvador: Light bulb cuz like how they worked at night - they could see better with the light improvements and how long it lasts. The telephone is like you can talk long distance like you can do stuff you couldn't do before.

Interviewer: Yeah. So are these things still relevant today?

Gebre: $\quad$ Yes. We've still got the light bulb, but it's actually more improved. They make it differently. They can make it longer now.

Santiago: $\quad$ And there's different types of light bulbs.

Gebre: $\quad$ And then the (xx) improved it to make it longer instead of keeping it at their house.

Santiago: And you can reach even longer.

Interviewer: Say that again?

Santiago: $\quad$ You can reach even longer distances. (focus group, 11/24/15)

Once Salvador identified the importance of "inventions" and "improvements," Santiago and Gebre elaborated, adding that the "different types of light bulbs" and telephones that can "reach even longer distances" contributed even more than previous versions. This is the same argument Yousuf made during his individual interview when he reported learning about "the one that creating [sic] the light, electricity and the phones to call so it could be easier" (interview, 12/9/15). Later during the Garden View focus group, Gebre explained how he determined the order of importance for the six images:

Gebre: $\quad$ And then it was Alexander Graham Bell was before Thomas Edison.

Interviewer: What do you mean "before?"

Gebre: He made...

Santiago: He said most important. 
Gebre: $\quad$ Because we can work without an improved light bulb. There was already the light bulb to make it later. We could have invented that later, but if no one invented the telephone, how would we speak to each other? I think that one goes first. (focus group, 11/24/15)

Using the example of the light bulb, Gebre argued that the impact of the particular inventions should be used to determine the importance and order of the picture cards. This example demonstrated how participants attributed historical significance to those people (i.e., Alexander Graham Bell and Thomas Edison) and processes (i.e., inventing or improving technology) that had historical or contemporary relevance in daily life.

In summary, ten of the eleven participants used the nation-building narrative when they ascribed historical significance to people and events based on notions of progress and development. These students particularly focused on the notion of "building" the United States in their historical perspectives. However, I found that one student, Yonas, did not employ the nation-building narrative. Though he nominated presidents as important historical figures, Yonas identified both Barack Obama (interview, 9/15/15) and George Washington (interview, 12/8/15) as "a nice guy" without demonstrating additional historical knowledge regarding their roles as president. Yonas added that he learned about Obama "in English" class (interview, 9/15/15), indicating that his nomination of the current president reflected name recognition, rather than perceived historical significance. By contrast, Yonas employed the concept of "helping people" when he explained why he thought George Washington (interview, 9/15/15) and Abraham Lincoln (interview, 12/8/15) were important historical characters. Yonas provided no details to explain his assertion that George Washington "helped the poor people" (interview, 12/8/15), but rather appeared to rely on the general concept of "helping" others as rationale for historical significance. As such, I argue that Yonas' 
historical perspectives reflected the equality narrative, which I describe in the following section, rather than the nation-building narrative.

\section{The Equality Narrative}

Ten of the eleven participants frequently voiced notions of equality, rights, and freedom in their interviews and class discussion. In this section I examine these themes in the form of the equality narrative. In the following section, I outline the ways in which students described the absence of these themes using what I have named the discrimination narrative. When using the equality narrative, the participants focused on historical figures who helped others and pursued equal rights. In this section, I first describe the ways in which equal rights were normalized and operationalized in students' discourse. I next focus on the term "freedom" and the ways in which students employed the term freedom in their descriptions of the equality narrative. I then examine the participants" employment of the term "rights" as a characterization of the pursuit of equality. I close this section with Marisol, who was the only student who did not employ the equality narrative (or the discrimination narrative) in her historical perspectives.

\section{"Not treated bad, treated good": Establishing the standard of equal rights.}

When the participants described their perspectives on U.S. history, they drew regularly on the concept of equal rights. For example, when presented with a question on what immigrants most needed to know about U.S. history, Yousuf's summary drew on the equality narrative: “About racism and stuff, every people’s like equal, not treated bad, treat good" (Yousuf, 12/9/15). An Iraqi immigrant, Yousuf identified the equality narrative_-“every people's like equal" — as the most relevant to immigrants (I examine this link more closely in a later section of this chapter). While Yousuf first invoked the 
concept of "racism," he concluded that in the United States people are "not treated bad, [but are] treated good." Yousuf's framing and assertions about U.S. history exemplify the participants' employment of the equality narrative based on an assumption that equal rights are normative.

Even when students did not use specific terms (i.e., equal), they invoked the equality narrative in describing and questioning U.S. history. In his September interview, Yonas, an emergent bilingual from Eritrea, nominated Abraham Lincoln as an important person in U.S. history: “Because he's nice. And he help a lot of people... [help] Black American" (interview, 9/15/15). While the first part of Yonas' statement provided few insights into the knowledge or values that informed his historical perspectives, Yonas' identification of "Black American[s]" as being in need of "help" suggested that he was referencing the standard of equal rights. As such, Yonas appeared to recognize that African Americans faced inequality and subsequently attributed historical significance to Lincoln based on an understanding that Lincoln's actions remedied the inequality. In an exchange during Mr. Mitchell's class, Maria, a U.S.-born bilingual Latina who reported traveling to Honduras to visit family every summer, provided a similar example of employing the equality narrative without using terms such as "rights":

Mr. Mitchell describes the lesson for tomorrow with a part of a movie that demonstrates how a "boy was taken to a school" following the Massacre of Wounded Knee. He explains that the movie shows how the boarding schools attempted to assimilate Native American students by "teaching them how to be American and erase everything about them." Maria asks, "And their parents approved?" Mr. Mitchell responds, "Their parents didn't have too many choices." (fieldnotes, 9/10/15)

When Mr. Mitchell introduced the practice of sending Native American children to boarding schools, Maria interjected to ask whether "parents approved" of this action. Mr. 
Mitchell's response made explicit the role of "choices" and decision-making power embedded within Maria's inquiry. Maria grappled with how the practice of removing children from their families and "teaching them how to be American" could be legitimized in light of the equality narrative. In short, the basic assumption that people should "not [be] treated bad, [but] treated good" served as a critical framing device exemplified in students' efforts to establish the standard of equal rights within their perspectives on U.S. history. In the following section, I examine how students interpreted the concept of "freedom" as an element of the equality narrative.

"They were trying to fix the world": Conceptualizing freedom. The participants referred frequently to the concept of "freedom" in their descriptions of important people and events in U.S. history. Many of these references pointed to the end of slavery as a specific example of freedom being expanded. For example, during her December interview Maria identified the importance of freedom when she nominated the end of slavery as an important event in U.S. history:

I learned that they were trying to fix the world, and that the Union was spreading. President Andrew Jackson and Abraham Lincoln were rivals. Andrew Jackson, Andrew Johnson, was part of the South, and Abraham Lincoln was part of the North. Abraham Lincoln was trying to stop slavery and get the Union and South back together so they wouldn't undo. Yeah, I'm a pretty smart kid. I am very fancy with my language. (interview, 12/14/15)

Maria introduced her detailed description of Lincoln's historical significance by stating that Lincoln and others "were trying to fix the world." In Maria's description, "trying to stop slavery" reflected the equality narrative, while Lincoln's efforts to "get the Union and South back together" mapped onto the nation-building narrative. Maria's overall assertion regarding "trying to fix the world" focused on the spread of freedom through the eradication of slavery as her statement "that the Union was spreading" paralleled her 
later remark about putting the country "back together." In short, the notion of "fixing the world" reflected the centrality of freedom within the equality narrative.

While Maria described the concept of "freedom" without using the term, many of her peers did the opposite, uttering the word "freedom" without defining its meaning. For example, Yousuf also identified freedom as central to Lincoln's historical significance: "Abraham Lincoln because he fight [sic] for freedom for the slaves" (interview, 9/9/15). In his second interview Yousuf connoted the concept of freedom once again, this time to justify his selection of the Civil War as important: "The Civil War between the South and the North about the freedom" (interview, 12/9/15). Through applying the same concept in multiple contexts, Yousuf demonstrated that the concept of freedom was significant in the equality narrative. Gebre also invoked freedom when describing the Civil War: "The Civil War helped...that was after the South....It was kind of between the South and the North a little bit and they were fighting for freedom of cause for Blacks" (interview, 9/9/15). In a classroom observation example, Javier applied the term "freedom" while analyzing a Reconstruction-era political cartoon as part of a gallery walk in Mr. Mitchell's class:

1:01 Javier and BA are describing a picture as having Blacks, slaves, and someone "having fun." Mr. Mitchell walks over and asks them what the "message" behind the political cartoon would be. BA says he doesn't know. Then Javier says, "I put freedom." Mr. Mitchell nods and says, "Exactly." (fieldnotes, 9/10/15)

In this exchange, Javier identified "freedom" as the important "message" behind the end of slavery. In each of these situations, the students demonstrated a strong word association between "freedom" and "slaves" within the context of discussions of Abraham Lincoln and the Civil War. In contemplating how students may have 
conceptualized freedom in these cases, returning to Maria's statement about "trying to fix the world" provides context.

In the context of the equality narrative, participant comments suggested that freedom signaled a righting of wrongs through a realization of equality. Maria used the term "fix" to denote this corrective process. In an assignment in which Ms. Rogers' students wrote a journal entry from the perspective of a Native American student who had recently been taken to a boarding school, Aras used the phrase "fight back" when he argued he would have resisted in order to preserve his "freedom":

If some one came in and told me to do life in a different way I would try to avoid every thing they do to me. I would try to think a way out of the place that they have me in. And if i didnt have a other choice I would have to exsept [sic] what they turned into. But I would try to fight back. I would not let no one take my freedom away. Well that's I think I am going to try to do. (student work sample, $10 / 14 / 15)$

Aras invoked the term "freedom" while referring to choice and self-determination. In this perspective-taking assignment, Aras asserted that without the ability to decide whether to attend the boarding school—which students had just learned involved getting one's hair cut and choosing an English name (fieldnotes, 10/14/15)—Native American children lacked "freedom" and thus lacked equality. In describing Reconstruction, Gebre also identified self-determination as an element of freedom.

We have learned about Reconstruction between South and the North, how they've been fighting, how the North wants Reconstruction to happen so slaves can have freedom and have jobs to pay for their families. (interview, 9/9/15)

Gebre specified that "freedom" for slaves - more accurately former slaves in the context of Reconstruction — should include the ability to "have jobs to pay for their families." In these examples, the participants demonstrated an understanding of the concept of freedom that was broader than the mere absence of "slavery," but that instead required 
the ability to pursue and realize equality on either an individual or societal level. In the following section, I examine the concept of "rights" as the final element of the participants' historical perspectives found within equality narrative.

"I have a dream": Understanding rights as the pursuit of equality. The case study students' identification of the pursuit of rights in U.S. history provided the third element of the equality narrative. Many of the participants identified Martin Luther King, Jr. as personifying the equality narrative, and the pursuit of rights, in particular. For example, in his December interview Salvador detailed a simplified narrative that led to the need for and thus the importance of King:

Interviewer: Who are the 3 most important people in United States history? Salvador: I'd say George Washington, Abraham Lincoln, and Martin Luther King.

Interviewer: Can you say a little bit about why you chose each of those people? Salvador: I chose George Washington because he was the first president of the United States of America. Abraham Lincoln, he abolished slavery. Martin Luther King, Jr., he gave ... He was like civil rights, and when he gave the "I have a dream" speech, that's when it started all changing. Blacks had free access, just like Whites did, soon after. (interview, 12/14/15)

In Salvador's telling, George Washington laid a nation-building foundation, Abraham Lincoln "abolished slavery," and then Martin Luther King, Jr. embodied the pursuit of rights_- "He was like civil rights"—-within the larger equality narrative. Salvador described King's "I have a dream" speech as a catalyst that "started" change, leading to equality_-Black had free access, just like Whites did"—in a short amount of time. Aras likewise described King as important for his efforts in "changing" the system through promoting "free access" for African Americans: "Martin Luther King...was about how Whites and Blacks had to be separate so he tried to change that" (interview, 9/10/15). Aras identified the pursuit of equality as essential, attributing historical significance to 
King because he sought social "change," specifically the end of segregation. Aras was consistent in his determination of historical significance, months later arguing King was important "because he made White and Black people put together" (interview, 12/9/15). Aras reflected the equality narrative when he detailed King's work toward greater equality, specifically efforts to integrate_- “put together”- the races.

Through their descriptions of people pursuing and achieving rights over time, the students operationalized the concept of "rights" in an active manner. One element of this characterization was the articulation of what inequality or the absence of rights meant.

Yousuf introduced the term "racism" as an all-encompassing explanation for why various groups of people needed to pursue rights:

They didn't want no racism and stuff, they want everything equal....The Black people wasn't like the White people or the Chinese or Hispanics so they want others to see the same because they're just people, the womans [sic] the same as the mens here. I think Elizabeth was her name, the one that was for the womans to work, yeah. (interview, 12/9/15)

Yousuf suggested that four groups of people_- "Black people," Chinese, Hispanics, and women-lacked equality because they "wasn't like the White people" or "the same as the mens." As such, Yousuf explained, leaders like Elizabeth Cady Stanton led the effort for women to be treated "the same" in the workplace. Gebre also identified Martin Luther King's role in the "fight for Black people's rights to be able to not be treated that way" (interview, 12/8/15). Gebre specified the subservient role of African Americans - they had "to do stuff for other people that aren't Black" — as the impetus for King's advocacy work.

Santiago similarly first named the absence of rights before elaborating on the importance of rights in a way that mapped onto the equality narrative. During one of the 


\section{NORTH OR SOUTH:WHO KILLED RECONSTRUCTION?}

\section{By:}

I think that southern resistance is the blame for killing reconstruction.

CRACK! Do you know who killed reconstruction?

The north won the Civil war. The north and South fought because the southern states wanted to succeed and they wanted to keep slavery but the North wanted to give blacks freedom and rights.Reconstruction was the years between 1865 and 1877 when the nation reunited and rebuilt after the Civil war.

Both Southern resistance and Northern neglect contributed to the death of reconstruction. However, Southern resistance was the the greater problem. These are three reasons that $\mathrm{I}$ believe Southern resistance is the most responsible for killing reconstruction.The Ku Klux Klan killed carpet baggers and government officials and terrorized them. The Southern resisted changes from the North.Also the South suppressed the freedom.

This is what I learned from the documents that support my reasons. The South killed reconstruction because the KKK was killing government officials and carpet baggers and they also threatened them them.Also the South resented the scalawags and carpetbaggers.My last reason is that the South also suppresed the freedom. The cause of reconstruction ending are still important to study today because reconstruction ended because the South was being racist and killing carpetbaggers and govrnment officials and threatening people and they didnt want blacks to have equal rights.

Figure 11. Santiago's Essay on Reconstruction

classes in Ms. Rogers' unit on Reconstruction, Santiago defined the Ku Klux Klan $(\mathrm{KKK})$ as a "secret organization that tried to keep African Americans from getting the same rights" (fieldnotes, 9/1/15). At the end of the unit, Ms. Rogers assigned a fiveparagraph essay to students with the prompt: "Who Killed Reconstruction?" Santiago wrote that "southern resistance is the blame for killing reconstruction" (see figure 11). 
Santiago concluded that "the South was being racist and killing carpetbaggers and govrnment $[$ sic $]$ officials and threatening people and they didnt want Blacks to have equal rights" (student work sample, 9/11/15). During his September interview approximately two weeks later, Santiago explained how rights and the equality narrative framed his understanding of U.S. history and Ms. Rogers' recent instruction:

Interviewer: What seems important about Reconstruction?

Santiago: Reconstruction because that was when the slaves were getting their rights and then basically the Americans were taking them away. Then they're still trying to get their rights as in to vote and to be able to own properties and not be slaves. (interview, 9/14/15)

In both his essay and subsequent interview, Santiago identified the struggle over "getting their rights" as central to understanding Reconstruction and the challenges "Blacks" or "slaves" faced at the hands of "the South" or "the Americans." Santiago asserted that "the North wanted to give Blacks freedom and rights." His clear focus on "equal rights" mapped directly onto the equality narrative.

In summary, ten of the eleven participants employed the equality narrative as part of their historical perspectives. The equality narrative consisted of three parts. The first component included establishing a standard of equal rights through routinely identifying when rights were present or missing. The second element focused on efforts to "fix the world" through spreading freedom, particularly through attributing the end of slavery to Abraham Lincoln and the fighting of the Civil War. The third aspect was describing rights as the pursuit of equality, exemplified in the work of Martin Luther King, Jr. Together the participants' historical perspectives demonstrated the prevalence and multiple facets of the equality narrative in U.S. history. 
Only Marisol did not use the equality narrative or the discrimination narrative. While Marisol's English language proficiency clearly mediated her understanding of Mr. Mitchell's classroom instruction, analysis of her limited descriptions of historical knowledge revealed that she used the nation-building narrative when attributing historical significance. For example, Marisol identified George Washington as "el primer president/the first president" (interview, 12/18/15), a reflection of the role of titles and institutional positions in her assessment of historical significance. Though Marisol nominated few people or events during her interviews, her explanation for identifying "Mr. Martin Luther King" suggests that she over-generalized the importance of political office: "Creo que fue presidente de Estados Unidos./I think he was the U.S. president" (interview, 9/16/15). In this clear example of “misremembering” (Wills, 2011), Marisol employed the nation-building narrative to justify her selection of King. The fact that Marisol did not address the concepts of equality or rights when discussing King demonstrates her broader omission of the equality narrative, as well as the discrimination narrative. In the following section I examine the third and final theme that marked students' perspectives on U.S. history-the discrimination narrative.

\section{The Discrimination Narrative}

The same ten participants who employed the equality narrative also used the discrimination narrative when describing their perspectives on U.S. history. When employing the discrimination narrative, students' historical perspectives focused on historical individuals and groups who lacked rights and freedom. In this section, I examine the presence of the discrimination narrative in the case study students' discussion and descriptions of U.S. history. I first examine the ways in which students 
defined the concept of discrimination. I next describe how students described the presence of discrimination in U.S. history. I conclude with a section on students' comparisons between discrimination in the past and their perspectives on the present.

"Blacks were being treated really bad": Defining discrimination. Though the participants rarely employed the term "discrimination" during interviews or classroom observations, they routinely identified examples of systemic discrimination. When employing the discrimination narrative, students most frequently characterized discrimination as the mistreatment of marginalized groups. For example, Santiago provided clarity on the relationship between discrimination and rights during his December interview when he summarized the three events in U.S. history that he believed to be most historically significant:

Interviewer: What are the three most important events in the United States history?

Santiago: $\quad$ Slavery, African Americans had their rights and basically Reconstruction.

Interviewer: Why did you choose these events? What makes them important?

Santiago: $\quad$ Slavery I chose it because that was when Blacks were being treated really bad. What was the next one?

Interviewer: I wrote down slavery and when Blacks got their rights and then Reconstruction.

Santiago: Then the rights because that was really important because the slaves were really trying to get their rights for a really long time. (interview, 12/16/15)

In his description, Santiago established the dichotomy of slavery—in which "Blacks were being treated really bad"—and a time when "African Americans had their rights." $\mathrm{He}$ stated that before Reconstruction "African Americans," "Blacks," and "slaves were really trying to get their rights for a really long time.” By noting that the quest for rights took "a really long time," Santiago identified a prolonged period of inequality and discrimination. In his December interview, Yonas framed the historical discrimination of 
African Americans similarly, using the term "racist" when he concluded: "Some White man-like the Americans, they're racist to the Black American" (interview, 12/8/15). In their interview responses, Santiago and Yonas both identified the role of race in their examples of discrimination.

In a telling exchange, Isabel described the tension between the discrimination narrative and the nation-building narrative through her analysis of the treatment of Native Americans:

Interviewer: I do want to ask one more question about the Indian and American wars. When you think about Native Americans getting pushed off of their land, is that important because of what it did for the Native Americans or what it did for the United States?

Isabel: $\quad$ Both. The United States got more land and more places to settle into, but the Native Americans, they were getting killed and their food supply was also getting killed once Americans tried to...[Americans] were doing sports as killing [Native Americans'] main food supply. (interview, 12/10/15)

Whereas Santiago defined discrimination as the opposite of equality, in this interview exchange, Isabel suggested that "both" the nation-building and discrimination narrative could be employed when describing particular events or processes in U.S. history. However, after Isabel noted that "the United States got more land and more places to settle," she then pivoted and described both how Native Americans "were getting killed" and how "Americans" were actively "killing Native Americans' main food supply" in the form of the buffaloes. As such, Isabel clarified the potential for multiple narratives to coexist in such a way that the discrimination narrative did not need to be supplanted by another narrative. In the following section, I examine how participants employed these definitions of discrimination while describing their historical perspectives. 
"We took their land": Identifying discrimination in U.S. history. Across the data sources, examples of discrimination consistently marked participants' historical perspectives on U.S. history. These examples occasionally corresponded to notions of nation-building and equal rights, providing multiple perspectives on the same events. For example, when asked what he had learned in Ms. Rogers' class, Salvador summarized learning "about American Indians, and how we forced them...We took their land." (interview, 12/14/15). While Isabel had previously referred to the same processes as the means by which “our nation got bigger” (interview, 9/10/15), Salvador's description focused on the Native American perspective, specifically the discrimination of Native Americans during the period typically referred to as European Americans' westward expansion. In organizing further analysis of students' configuration of the discrimination narrative within U.S. history, I draw on an analytic note from my fieldnotes in Mr. Mitchell's class: "[AN: Blacks $\rightarrow$ Indians $\rightarrow$ Immigrants]" (fieldnotes, 10/13/15). This chronological and thematic orientation serves as an organizer as I describe student perspectives on the treatment of African Americans, Native Americans and immigrants.

Many of the participants provided examples of the relationship between African Americans and the discrimination narrative. Aras described how "African Americans, because of their skin color...weren't allowed to vote and they were slaves" (interview, 12/9/15). Felix recalled reading about literacy tests in a library book, explaining that the book he read provided more detail than Ms. Rogers had in class: "[The book] explained it because they said they had a whole bunch of questions and it was saying about an African American that did the literacy test, he got nothing right" (interview, 9/17/15). These 
examples demonstrate the ways in which students applied the discrimination narrative to history about African Americans.

When discussing discrimination against Native Americans, the participants alternately employed the nation-building narrative and the discrimination narrative. As noted above, Salvador held these competing narratives in tension when describing the processes of European Americans' westward expansion and the dispossession of Native Americans' land:

Salvador: $\quad$ American Indians and how we forced them to ... We took their land, and like child labor laws, and then how it was before laws were passed. We learned about ghettoes, tenements, and immigration, like all of ... Right now, we're talking about tolerance and how some people are tolerant to other people, and then...

Interviewer: What does it mean to be tolerant?

Salvador: $\quad$ You don't have to like them, but you have to show them a decent amount of respect.

Interviewer: If you think about this idea of being tolerant, and some of the examples you gave, have you talked about, or what's your opinion about whether people have tolerated the American Indians?

Salvador: $\quad$ Some people did, some people didn't. Most likely, the British didn't because they kind of forced them off their land. They didn't like them. They didn't respect them.

Interviewer: When you first mentioned the American Indians, you said "We forced them off their land, and we took their land." In that case, is "we" the British? Are you talking about like you and me, or the people in Ms. Rogers's class? Who's the "we" in that situation?

Salvador: I kind of meant like the whole British, the British who came over to America. (interview, 12/14/15)

Salvador defined being "tolerant" as "showing them a decent amount of respect" and juxtaposed the notion of tolerance with the treatment of "American Indians." He clarified that the "we" in his statement was "the British who came over to America" to whom he attributed the "forced" removal of the Native Americans from "their land." During a 
class discussion in Mr. Mitchell's class Maria and Yonas also identified multiple

perspectives before highlighting the discrimination of Native Americans:

Yonas asks Mr. Mitchell a question. "Mister, the Mexican and Indian—why did they fight?" Mr. Mitchell responds that he wants students to be able to answer that question "for yourself" and opens it up for other students to respond. Maria states that "Whites wanted Native Americans on reservations." BE adds, "The government wanted Indians' land that was promised to them." A few other students make comments before Yonas speaks up again: "The government has more the American Indian land. The American Indian have a little - not like the government." (fieldnotes, 10/16/15)

When Yonas asked a question about why there was conflict between the Mexican government and certain Native American groups, Maria referenced the policy of placing

"Native Americans on reservations" and another student added that "the government" enacted this policy in order to gain access to land previously "promised" to Native Americans. In her December interview, Isabel similarly described how Native Americans "were getting killed and their food supply was also getting killed once Americans tried to" settle the land (interview, 12/10/15).

Students particularly connected with the treatment of Native American children and referred to the practice of sending Native American students to boarding schools as a form of discrimination. For example, in the following classroom exchange students identified multiple examples of abuse perpetrated against Native American children:

12:36 Mr. Mitchell writes the word "assimilation" on the whiteboard. Miguel says, "They take away from the Indians...the kids." (He is referring to the boarding schools depicted in the movie during the previous period.) Mr. Mitchell follows up with a question: "What did they do to the kids?" Antonio says they had to "change their language." Miguel chimes in again saying they "have to speak English" and excitedly describing the scene in which a teacher washed a boy's mouth with soap. As the discussion continues, Yonas mentions that children had to change their clothes and "their necklace." Maria describes how the purpose of the boarding school was to prepare Indian children for "jobs in the future-American jobs." Mr. Mitchell says that the video didn't demonstrate this, but that the comment is a "very good one." He summarizes their discussion by 
stating that the boarding schools were focused on "killing the Indian" and assimilating the children "into being American." (fieldnotes, 10/21/15)

In this classroom discussion students named specific examples of discrimination that Native American children their own age had faced, including needing to "change their language" and "speak English." Mr. Mitchell's statement about "killing the Indian" provides an apt summary of the discrimination the case study students also identified.

In a third and final example, the participants used the discrimination narrative to describe the experiences of immigrants in U.S. history. Students particularly focused on the historical discrimination against Chinese immigrants. For example, in his December interview Yousuf summarized what he had learned in Mr. Mitchell's class by describing (a) "the light, electricity and the phones," and (b) "the Chinese immigrants, the racism and stuff' (interview, 12/9/15). Figure 12 depicts one of the political cartoons students

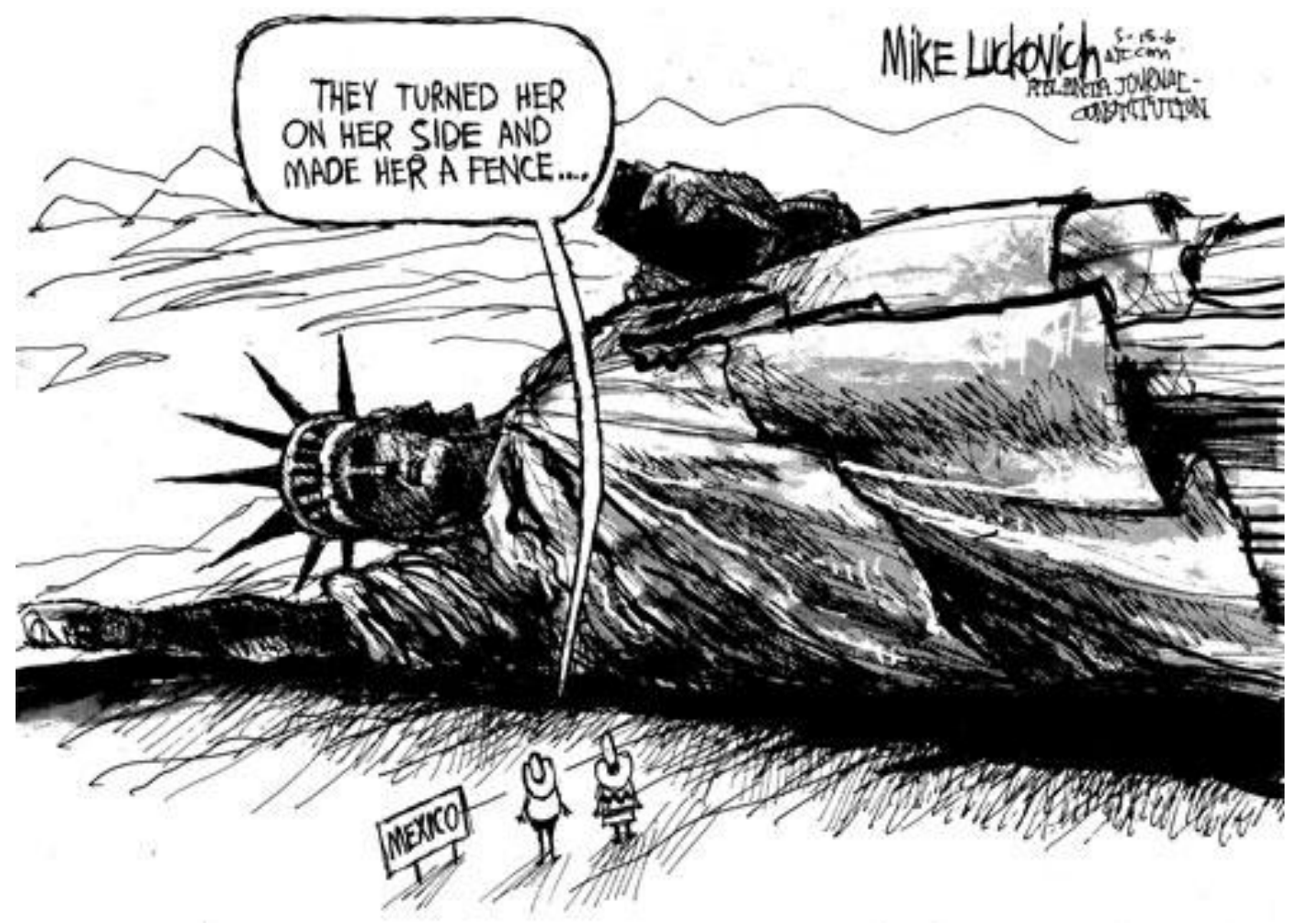

Figure 12. Political Cartoon on Immigration Policy. Copyright 2006 by Mike Luckovich. 
analyzed in Mr. Mitchell's class. In describing this image during her December interview, Isabel stated: "I see Mexico, the border and the Statue of Liberty on her side. It was blocking their path" (interview, 12/10/15). Isabel related this cartoon to Mr. Mitchell's instruction because "Asian and Chinese were winning and they started putting acts and laws so it'd be hard for them.... One act stopped them from coming in anymore" (interview, 12/10/15). Isabel explained that the historical passage of laws barring Chinese immigrants mapped onto the symbolism of "blocking their path" in the political cartoon. Aras identified a particular example of discrimination against Chinese immigrants in the story of the completion of the Transcontinental Railroad and the laying of the "golden" spike at Promontory Summit, Utah:

Aras: $\quad$ Chinese and Irish are fighting.

Interviewer: Chinese and Irish are fighting each other?

Aras: $\quad$ They're not fighting like...They were building the railroad. Interviewer: Okay.

Aras: $\quad$ But the Americans didn't take them in the picture, or anything.

Interviewer: Do you remember what was in that picture, where they were not included?

Aras: $\quad$ No.

Interviewer: I remember in class there was a photograph, when they finished the Trans-Continental Railroad?

Aras: $\quad$ Yeah, it was all just Americans.

Interviewer: And what do you mean by Americans?

Aras: $\quad$ They didn't want the Chinese to be in the picture.

Interviewer: Okay. If the Chinese were not Americans, who were the Americans in the picture? How would you describe them? How are they different from Chinese?

Aras: $\quad$ In their race. They didn't want Chinese people to be in the picture because they didn't want people to know that they built it. (Aras, $12 / 9 / 15)$

Aras first identified the notion of conflict regarding immigrants by describing how two groups of immigrants — the Chinese and Irish —were "fighting each other." He then corrected himself and cited the exclusion of the Chinese railroad workers from an official 
portrait, concluding that the Chinese immigrants faced discrimination, "because [the Americans] didn't want people to know" that the Chinese workers built the railroad. With these examples of racism and discrimination against African Americans, Native Americans and Chinese immigrants as a backdrop, I next examine the ways in which students employed the discrimination narrative when comparing U.S. history to the present.

"He is pretty much like Hitler": Comparing the past and present. In addition to identifying discrimination in U.S. history, many of the students employed the discrimination narrative in their analysis of the world around them. In a few instances, students directly compared the discrimination of the past to current events or contemporary examples, such as when one non-focal student compared the KKK to the Islamic State of Iraq and Syria (ISIS) during Mr. Mitchell's class (fieldnotes, 9/22/15). In other cases, students made more nuanced arguments.

Multiple participants identified Donald Trump as another modern example of discrimination. During the focal group with the five students in Ms. Rogers' class, I asked the students whether they thought discrimination was more or less prevalent than at other times in U.S. history:

Santiago: I think it's kind of both

Felix: $\quad$ Yeah, it's both, cuz you see Donald Trump right now...

Interviewer: Uh-huh...tell me more about-I mean, I certainly know who Donald Trump is, but tell me more about what you're thinking. Santiago: He's being really racist to Hispanics, especially Mexicans. He says he's going to deport...

Felix: $\quad$ All of them-he's funny!

Interviewer: Like funny in a good way or funny in a bad way?

Felix: In a bad way...

Santiago: $\quad$ Funny in a DUMB way...

Felix: Really dumb way!

Santiago: He's so dumb. 
Felix: $\quad$ How you going to deport like...

Gebre: $\quad$ ALL the Mexicans?

Aras $\quad$ Exactly! (focus group, 11/24/15)

A Mexican immigrant himself, Santiago asserted that Trump's statements about deporting undocumented immigrants meant Trump was "being really racist to Hispanics, especially Mexicans." Santiago and Felix asserted that Trump's plan was "dumb," which reflected both their disagreement with Trump's proposed plan and an underlying questioning of how it could be carried out. Later in the focus group, Santiago identified how stereotypes and over generalizing contributed to discrimination: "They're like mistreating all the people who are Arabic just cuz of ISIS they think all the Arabics are terrorists when they're really not and you just don't know about it. And they just say that because they want to" (focus group, 11/24/15). Santiago's added comment about "people" making disparaging comments "because they want to" provided insights into the perceived callous nature of the discrimination narrative as students saw it unfolding in current events. The previous characterizations of Trump's deportation plan as "dumb" mapped onto Santiago's conclusion that those in power were able to make statements and decisions without considering how they affected the lives of others. In his December interview a few weeks later, Santiago again cited Trump as leading an anti-immigrant initiative:

In the past, people didn't really care [about immigration] as much. Right now, there are people who are more racist, and they don't want immigrants to come. Like Donald Trump, he wants all the immigrants to go back when he becomes president, and when immigrants first started coming here, people didn't really care because it was a benefit for them because their industries and factories would grow, and they would get more money off the workers. (interview, 12/16/15)

Santiago labeled people who "don't want immigrants to come" as "more racist" and then argued that "when immigrants first started coming here" the United States experienced 
positive outcomes "because their industries and factories would grow." Santiago's historical reference reflects instruction in Ms. Rogers' class, including identifying the "growing demand for industrial workers" as a reason for an influx of 26 million immigrants between 1870 and 1920 (fieldnotes, 10/26/15). For Santiago and some other participants, the historical reasons for and resistance to immigration sounded familiar based on their own experiences. In short, they found evidence for the discrimination narrative of U.S. history in both the past and the present.

In summary, the ten students who employed the equality narrative also used the discrimination narrative as part of their discussion and descriptions of U.S. history. Specifically, the participants addressed the concepts of racism and discrimination as part of their classroom discourse, their historical perspectives, and their comparisons between the past and present. As I found when analyzing the presence of the equality narrative, Marisol was the only student who did not employ the discrimination narrative. In the final section of this chapter, I explore how the case study students' experiences and other characteristics interacted with their historical perspectives.

\section{Interactions between Student Characteristics and Historical Perspectives}

While each of the eleven case study students employed at least one schematic narrative template when describing their historical perspectives, at times the participants also appeared to struggle to reconcile the official U.S. history curriculum with their own experiences and social identities. In these cases, students appeared to silence their own experiences as they privileged the official curriculum. At other times, students employed the discrimination and equality narratives as a bridge between the official curriculum and their historical perspectives. During these exchanges, student characteristics served as 
secondary mediators in students' historical perspectives, particularly in regards to which narratives participants employed and how they judged the official curriculum.

In this section of the chapter, I first examine interactions between students' schooling experiences and their historical perspectives. I follow this with analysis of students' language learning experiences and the social context in which the study took place. I conclude with sections focused on aspects of the participants' identity, specifically race and ethnicity, national origin, gender, and religion. While each of these student characteristics has empirical and theoretical significance from the literature, the analysis found in this chapter is limited to the evidentiary warrant found within the data.

\section{Schooling}

Formal schooling served as a primary mediating factor in the development of the participants' historical perspectives. Students reported learning about history-the official curriculum - in school and named primarily school-related entities as the most trustworthy sources of historical knowledge. In addition, participants' historical perspectives reflected not only the historical knowledge and attributions of historical significance presented in Ms. Rogers' and Mr. Mitchell's classes, but those outlined in the state-mandated curricula for previous grades. In the following section I explore further the interaction between schooling and students' formation of perspectives on U.S. history. I first describe how the instruction observed in Ms. Rogers' and Mr. Mitchell's classes provided insights into students' historical perspectives. I next examine the concepts of historical sourcing that students described. I then identify commonalities between the Virginia SOLs and students' nominations for important figures and events in U.S. history. 
"Everything so I could be ready": History as academic subject. The

participants identified U.S. history primarily as an academic subject that they learned about school. While the historical perspectives students described consistently referenced formal history instruction, students also occasionally made this link explicitly. For example, when I asked Yousuf how he decided what was important in history, he replied, "I don't care about the Iraq because I'm not going to go over there to school and learn; I care about America because it's really important in the future when I be in high school or college" (interview, 12/9/15). Yousuf clearly defined history as an academic subject, one which he sought to master in order to gain access to further education and his long-term goals. For Yousuf and many of his peers, the term history signified the content presented in schools. When I asked Yousuf to identify who he would like to learn about in history class, he replied simply, "Everything so I could be ready" (interview, 12/9/15). Yousuf's response revealed an understanding of a fixed curriculum with the student as a recipient tasked with mastering "everything" in order to be successful in school. In this section, I examine the connection between how students described their historical perspectives and their experiences in history classrooms.

Overall, the participants relied heavily on previous history instruction when describing their historical perspectives. For example, during the December interviews, nine of the eleven participants reported that they had previously studied at least two of the three people that they nominated as historically significant. Five of these students named only people that they had learned about in a history class. In addition, participants frequently used examples from classroom instruction when constructing the narratives that mediated their perspectives on U.S. history. For example, during her December 
interview, Isabel described learning about specific examples of violence against Native Americans while in Mr. Mitchell's class: "When we were learning about the American Indians, about the way they would also cut off children's scalp and they would get it for reward money" (interview, 12/10/15). Isabel reported reading about different Native American tribes outside of school, yet her focus on a vivid example of discrimination against Native Americans (i.e., scalping children) reflected the class discussions on the topic during Mr. Mitchell's Westward Expansion unit. Specifically, Isabel's description of scalping children for money mapped onto a video clip on Geronimo and the Apache as they struggled to resist both U.S. and Mexican government forces (fieldnotes, 10/16/15). In a similar example of Mr. Mitchell's instruction mediating student discourse, students provided commentary on the tactics used to punish Native Americans students while they watched a video on boarding schools:

12:55 On the movie, the headmaster of the Indian boarding school makes a boy bite soap, telling him to "never speak Indian again." Javier calls out, "That's how they used to clean your mouth." Yonas chimes in, "If you say a bad word they make you eat soap." (fieldnotes, 10/20/15)

During a class discussion the following day, students drew directly on these previous observations when Mr. Mitchell asked them to define the term "assimilation":

12:36 Mr. Mitchell writes the word "assimilation" on the whiteboard. Miguel says, "They take away from the Indians...the kids." (He is referring to the boarding schools depicted in the movie during the previous period.) Mr. Mitchell follows up with a question: "What did they do to the kids?" Antonio says they had to "change their language." Miguel chimes in again saying they "have to speak English" and excitedly describing the scene in which a teacher washed a boy's mouth with soap. As the discussion continues, Yonas mentions that children had to change their clothes and "their necklace." Maria describes how the purpose of the boarding school was to prepare Indian children for "jobs in the future-American jobs." Mr. Mitchell says that the video didn't demonstrate this, but that the comment is a "very good one." He summarizes their discussion by stating that the boarding schools were focused on "killing the Indian" and assimilating the children "into being American." (fieldnotes, 10/21/15) 
In this exchange, Yonas, Maria and other students listed specific examples of how Native American students were abused in the boarding schools. Antonio and Miguel, both nonfocal student emergent bilinguals, first identified how Native American children had to "change their language" and were forced "to speak English," repeating the specific details that Javier and Yonas had noted while watching the video during the previous day's lesson. Yonas then named clothing and appearance as outward signs of assimilation. These two examples demonstrate the ways in which instruction on American Indians mediated students' meaning making regarding what was important to know and how the discrimination narrative best characterized this process from U.S. history.

Other examples provide similar insights into how students' historical perspectives directly linked to classroom experiences. As described in a previous section, students in Ms. Rogers' class were particularly dismayed that Chinese railroad workers were excluded from a commemorative photo at the completion of the Transcontinental Railroad and the laying of the "golden" spike at Promontory Summit, Utah. During class discussions of this event, Gebre was incredulous (fieldnotes, 10/12/15) and the following day Felix described this decision as "pretty messed up" (fieldnotes, 10/13/15). Two months later, Aras referred specifically to the exclusion of the Chinese workers from the photograph during his December interview. In Mr. Mitchell's class, Yousuf (interview, 12/9/15) and Isabel (interview, 12/10/15) also named the plight of Chinese immigrants as historically significant in their December interviews. The prominence of the photograph and the decision to exclude Chinese workers provided students with a vivid example of the discrimination Chinese immigrants faced. In turn, students attributed meaning and 


\section{The North or South who killed Reconstruction? I think It was Southern} Resistance was to blame for killing Reconstruction.

The Civil War has ended, buildings have been were destroyed and the North wanted to rebuild the buildings thus, Reconstruction. But the South didn't want to help the kkk killed carpetbaggers and terrorized government officials.

Reconstruction; The years between 1865-1877 when the nation reunited and rebuilt after the Civil War ended

One reason I believe southern resistant is the most responsible for killing Reconstruction The kkk resented scalawags and carpetbaggers. The kkk was trying to end reconstruction because they were against freeman having jobs. The kkk stabbed and hung John W. Stephens.

This is what I learned from the documents that support my reasons. The kkk whipped colby and told him to vote the radical ticket. They also offered colby $\$ 5,000$ to go with them after whipping him. The kkk also killed carpetbaggers and hung them.

Figure 13. Salvador's Essay on Reconstruction

historical significance to this event based on the instruction in Ms. Rogers' and Mr.

Mitchell's U.S. history classes.

In addition to weaving symbolic elements of history instruction into their historical perspectives, students also reported more trivial characterizations from history class when they described U.S. history. For example, Salvador described being "surprised" that "the North gave up on the freedmen like the Black slaves" (interview, 9/16/15). Salvador's characterization of Reconstruction failing because "the North gave up on the freedmen" mirrored the arguments Ms. Rogers and the gifted education teacher, Ms. Andrews, had presented in class. Ironically, only five days previously, Salvador had argued the opposite perspective in his essay on the subject when he wrote that "Southern Resistance was to blame for killing Reconstruction" (student work sample, 9/11/15). Salvador wrote his essay in response to the prompt his teachers provided and included 
many supporting details from the primary sources students had analyzed in class (see Figure 13). His decision to attribute the failure of Reconstruction to the North notwithstanding, the mere fact that Salvador described the North as "giving up" on Reconstruction and freedmen demonstrates the role this unique framing played in mediating Salvador's meaning making of the events following the Civil War. In a similar example, both Gebre and Aras described Jane Addams' Hull House as a “daycare” during their focus group interview (focus group, 11/24/15). This specific term had first been introduced during class discussion about a month before when Ms. Rogers asked students to explain what they had read about Hull House and Santiago described it as a "daycare" where Jane Addams and others "helped children" (fieldnotes, 10/29/15). This description was then reinforced when a study guide presented at the end of the unit stated that Hull House "provided a home and daycare for children" (fieldnotes, 11/5/15). In short, Gebre and Aras' identification of Hull House - an immigrant support center providing many different services - with a colloquial term that had a narrow focus reflected the significant role that classroom discourse and instruction played in the meaning they attributed to this particular historical social institution. Together, the examples above demonstrate that the history instruction documented through observations and document collection mediated students' remembrance of and attribution of historical significance to specific themes and events in U.S. history. In the following section I further examine the relationship between students' schooling and historical perspectives through analysis of the sources of historical knowledge that students identified as trustworthy. 
Table 14

Student Nominations for Credible Sources of History

\begin{tabular}{lcl}
\hline \multicolumn{1}{c}{ Source of History } & $\begin{array}{c}\text { Number of Student } \\
\text { Nominations }\end{array}$ & \multicolumn{1}{c}{$\begin{array}{c}\text { Sample Student } \\
\text { Explanation }\end{array}$} \\
\hline Teacher & 6 & $\begin{array}{l}\text { Identified by name or } \\
\text { generic "teacher" } \\
\text { "History textbooks"; library } \\
\text { books } \\
\text { "Tooks/textbooks }\end{array}$ \\
Parent & 4 & $\begin{array}{l}\text { "TV news"; "history } \\
\text { teacher in Iraq": "Greek } \\
\text { mythology" } \\
\text { "Internet"; "Wikipedia"; } \\
\text { YouTube }\end{array}$ \\
\hline
\end{tabular}

Note. Nominations reflect December interviews with eleven case study participants.

"I guess they have to be important for us to learn about them": Credible

sources of historical knowledge. The participants identified primarily school-based sources of historical knowledge as credible. Santiago captured their overall approach when, in his first interview, he articulated a simple rationale when he explained that he thought Abraham Lincoln, Robert E. Lee and Frederick Douglass were important: “That's what we learned about today" (interview, 9/14/15). Santiago's reference to that morning's class reflected Ms. Rogers' instruction on the "Three Men of Honor" pictured in her PowerPoint presentation and on a graphic organizer (fieldnotes, 9/14/15). When I asked Santiago to elaborate, he stated: "I guess they have to be important for us to learn about them." Santiago's explanation exemplifies a perspective in which students identified the history teacher and other school-based resources as trustworthy sources. In this section, I examine the assumptions and judgments students articulated when naming credible sources of historical knowledge.

A majority of Santiago's peers in the study expressed similar trust in the sources of history found at school. As Table 14 illustrates, six of the eleven case study students 
identified the teacher as "the most believable" source of historical knowledge. The participants' reliance on and deference to the teacher were particularly evident in a number of naturalistic encounters. In the first example, Santiago answered a question and then appeared to deflect Ms. Rogers' request for him to explain his response:

A student was reading aloud from the textbook about the Southwest region, and came across the word Tejano. When Miss Rogers asked what the word meant, Santiago said something that Miss Rogers wasn't able to hear. When she asked Santiago to repeat it, he said, "I'm not the teacher." Miss Rogers persisted, and Santiago eventually told her and the class that it meant "cowboy hat." Miss Rogers then asked if her friend would know that the word Tejano meant a cowboy hat. Santiago first asked where the friend was from. "Here," Ms. Rogers said. Santiago asked where "her parents" were from and Ms. Rogers said, "They're from here, too." Based on this information, Santiago concluded that Ms. Rogers' friend would not know the term because she is "not Mexican" and "Mexicans are the ones that use that word." (fieldnotes, 9/30/15)

During his December interview, I read this field note excerpt to Santiago and asked him to interpret his actions during this event. Santiago explained that he at first deferred to Ms. Rogers because "the teacher is someone who teaches the student...she shows us about things that happened in history. She helps us learn about it" (interview, 12/16/15). In this classroom exchange and his subsequent explanation, Santiago demonstrated deference for Ms. Rogers as "the teacher" who "shows" students "about things that happened in history."

Four of the case study students also named textbooks or library books as trustworthy sources. The status of textbooks, in particular, reflected the ways in which students had interacted with these resources in the classroom. During the December interview, Gebre summarized the role of textbooks within Ms. Rogers' class:

We read our textbooks. We look for the answers for things and we read textbooks, our textbooks for the answers mostly and [Ms. Rogers] tells us to read the pages if we don't have our textbooks to study and all of those things. (interview, 12/8/15) 
Gebre explained that textbooks provided "the answers" and that Ms. Rogers "tells" students to use textbooks as a source of knowledge. Gebre's explicit reference to Ms. Rogers' use of textbooks suggested that the credibility the case study students attributed to teachers could at times be transferred to textbooks and other resources. Among the other three participants who identified written sources as trustworthy, Aras also noted that Ms. Rogers used "mostly textbooks" during class (interview, 12/9/15). Isabel reported reading "stories about how their life was," adding, "They're not fiction" (interview, 12/10/15), while Javier described "checking out some history books" at the library (interview, 12/16/15).

In addition to the school-based sources of historical knowledge detailed above, four of the case study students also nominated their parents as credible sources. However, many of the students specifically stated that sources of history at home were less favorable than those at school. For example, Isabel suggested that level of detail led to increased credibility: "At home the history is different because at school, they have more...It's like more information about stuff. They give you specifics, but at home they just give you the general idea" (interview, 12/10/15). Aras first stated that history can be "complicated" and eventually reached the same conclusion Isabel had made about school history including more "details":

"At home it's complicated. At school it's easy. You could learn more and there's more stuff to add on... Some of the stuff we're missing. Some stuff he doesn't talk about but when you go to school they put in little details that you should know about." (interview, 12/9/15)

Marisol attributed the discrepancy between what she learned about history at school compared to what she learned at home to what was available on television, concluding, "I learn more at school and there's not much information on TV" (interview, 9/16/15). 
Yousuf similarly compared his perspectives on what his father and his teacher each knew about U.S. history: "Teachers know a lot information [sic] than my dad and my mom knows. My dad knows about America but not that much. The teachers know a lot" (interview, 12/9/15). In short, a majority of the case study students identified their history teacher and school history more generally as a primary source of knowledge on U.S. history, even to the point of discrediting other sources of history. In the following section I compare students' nominations of significant historical people and events to the SOLs to further examine the role of the official curriculum in shaping students' historical perspectives.

"Earlier, in other grades": The Standards of Learning. The majority of the people and events to which the participants assigned historical significance are found in Virginia's standardized curriculum. As noted in the previous section, students frequently reported that the historical figures they identified as important had been introduced during prior history instruction. For example, when Santiago attributed historical significance to George Washington, he did so based in part on having learned about Washington "earlier, in other grades" (interview, 12/16/15). Many other students also identified the people and events that they nominated as being significant in U.S. history as being taught in sixth grade or previous grades. In order to trace the prevalence of this canon of historical knowledge within the Virginia SOLs, I examined the Curriculum Framework documents published by the Virginia Department of Education (e.g., Virginia Department of Education, 2008c) This analysis revealed that students' selections closely aligned with the state-mandated official curriculum. In the following section, I examine the relationship between students' perspectives on U.S. history and the Virginia SOLs. 
Table 15

Student Nominations for Most Important People in U.S. History and the Standards of Learning

\begin{tabular}{lcl}
\hline \multicolumn{1}{c}{ Historical Figure } & $\begin{array}{c}\text { Student } \\
\text { Nominations }\end{array}$ & \multicolumn{1}{c}{ Standard of Learning References } \\
\hline George Washington & 11 & K.1; $1.2 ; 2.11 ; 3.11$; VS.6; USI.6; USI.7 \\
Abraham Lincoln & 7 & K.1; $1.2 ; 2.11 ; 3.11 ;$ VS.7; USI.9; USII.3 \\
Martin Luther King, Jr. & 4 & K.1; $2.11 ; 3.11$ \\
Barack Obama (President) & 2 & K.9; 1.3 \\
\hline Note. Nominations reflect December interviews with eleven case study participants. No
\end{tabular}

Note. Nominations reflect December interviews with eleven case study participants. No

other individuals were identified by more than one student.

Analysis of the Virginia SOLs revealed that students selected people from the official school curriculum when asked to nominate important individuals in U.S. history. George Washington was a consensus choice who all eleven students nominated (see Table 15). Washington appears in the Curriculum Framework for every set of social studies SOLs from kindergarten to the U.S. History I (USI), which was the sixth grade curriculum for the Garden View school district. Abraham Lincoln was the only other historical figure who a majority of the students selected. Lincoln is named in every set of SOLs from kindergarten to the U.S. History II (USII) curriculum, which Ms. Rogers and Mr. Mitchell taught to their seventh grade classes. Martin Luther King, Jr., the third most nominated historical figure, appeared in the SOLs for kindergarten, second grade and third grade. References to the president and President's Day in the kindergarten and first grade SOLs mapped onto student selections of current president Barack Obama.

I also found that some of the students' rationales for their nominations contained the exact phrases found in some of the SOL Curriculum Framework documents. The similarities between students' historical perspectives and the official curriculum were 
particularly evident in the case of George Washington. The same two sentences are used to describe George Washington in both the kindergarten and first grade Curriculum Framework documents: "He was the first president of the United States and is often called the "Father of Our Country"' (Virginia Department of Education, 2008a, p. 2, 2008b, p. 1). As noted in a previous section, multiple students used this very phrase when explaining their nominations. For example, Isabel credited Washington with helping found the United States as the "father of our country" (interview, 9/10/15). During interviews, four additional students said "He was the first president" when discussing their selections of Washington (Marisol, 12/18/15; Salvador, 12/14/15; Santiago, 12/16/15; Yousuf, 9/9/15). While Washington is described in more detail and using slightly altered phrasing in the SOLs for the upper elementary grades, the participants' interview responses indicate that the students continued to use these simple descriptors.

When I analyzed the events that students named as historically significant, I found less overlap in the SOLs for each grade level. The Civil War was the only event that a majority of the students identified (see Table 16). The four other events that received multiple nominations were the Fourth of July and Revolutionary War (each with three selections) and Christopher Columbus' exploration and the World Wars (each with two selections). I found that those case study students who had attended schools in Garden View or elsewhere in Virginia in the years prior to the study would have encountered the Civil War in the official curriculum in only fourth grade and sixth grade. The Revolutionary War and World Wars similarly appeared in only the upper elementary 
Table 16

Student Nominations for Most Important Events in U.S. History and the Standards of Learning

\begin{tabular}{lcl}
\hline \multicolumn{1}{c}{ Historical Figure } & $\begin{array}{c}\text { Student } \\
\text { Nominations }\end{array}$ & \multicolumn{1}{c}{ Standard of Learning References } \\
\hline Civil War & 6 & VS.7; USI.9 \\
Fourth of July & 3 & K.1; $1.3 ; 1.12$ \\
(Independence Day) & 3 & \\
Revolutionary War & 2 & VS.5; USI.6 \\
Columbus Exploration & 2 & USII.5; USII.7 \\
World Wars I \& II & $2.3 ; 3.3$ VS.2 \\
\hline
\end{tabular}

Note. Nominations reflect December interviews with eleven case study participants. No

other events were identified by more than one student.

grades. As such, the SOL documents provided significantly more complex descriptions for these events than those discussed above.

Meanwhile the early elementary references to the Fourth of July and Christopher Columbus focus primarily on the identification and commemoration of national holidays. While Santiago and Yousuf's citation of Columbus' historical explorations clearly had a different focus than the SOLs, the explanations Maria, Marisol and Javier provided for their selection of Independence Day focused on the festive and celebratory nature of the holiday. As such, the three case study students who named the Fourth of July as an important historical event (perhaps inadvertently) reflected the official curriculum found in the SOLs.

In total, the events students named as important in U.S. history mapped onto the official curriculum found in the SOLs. When coupled with the analysis of the people in U.S. history, the state-mandated curriculum clearly mediated students' attribution of meaning and significance in the formation of their historical perspectives. In sum, the 
schooling experiences of the case study students interacted with and greatly influenced the students' perspectives on U.S. history. In the following section, I examine the interaction between students' language learning experiences and historical perspectives.

\section{Language Learning}

Language learning experiences played a significant mediating role on students' historical perspectives as students with greater English language proficiency regularly articulated more detailed historical knowledge. Conversely, students labeled as emergent bilinguals expressed confusion and misconceptions more regularly than those identified as bilingual students. However, students with various levels of English language proficiency articulated complex notions of historical significance. In this section I examine the interaction between students' historical perspectives and their language learning experiences. I first describe the participants' linguistic characteristics. I next investigate the relationship between language learning and students perceptions of history. I then examine students' historical misconceptions.

"Bilingual—I speak Spanish and English": Participant linguistic

characteristics. Among the eleven students five were labeled as emergent bilinguals based on their WIDA assessment scores and six had "exited" status. Seven of the students identified Spanish as a first or heritage language while the other four named Arabic, Kurdish or Tigrinya as a first language. Seven of the eleven students selected the "Bilingual" descriptor cards during one or both of their interviews. Isabel offered a typical rationale for selecting this card when she stated: "Bilingual—I speak Spanish and English" (interview, 9/10/15). While Salvador was the only student who identified English as his "first language," the translanguaging (García, 2010; García, Woodley, 
Flores, \& Chu, 2013; Velasco \& García, 2014) he described while explaining his descriptor cards choices mirrored the contextual and intergenerational language practices reported by other students:

American-I was from Virginia. English speaker - that was my first language. Spanish I kind of had the same as English. I learned them at the same time.....My dad was raised in [Virginia]. He moved to Arizona then back here and then my mom she was born in Florida but then she got raised in West Virginia.... When my grandmother and grandfather are home, because sometimes they go to Mexico, when they're home I speak Spanish and English, but mostly I speak English. (interview, 9/16/15)

Salvador explained that he first learned English and concluded that he continued to "mostly speak English." As he linked his own parents' experiences to various locations, he similarly referenced a place-Mexico-in describing his grandparents and noting that his own use of Spanish primarily focused on interacting with them. Salvador explained that his use of multiple languages reflected different contexts and relationships within his bilingual family.

Javier reported a similar set of linguistic influences, in which family and geography determined his own translanguaging practices. Javier described speaking Spanish at home and then learning English at school. He reported speaking Spanish to the adults in his family as well as with his younger brother who had just started first grade. Javier explained that his brother only knew "a little" English because he had spoken Spanish at home (interview, 9/14/15). Javier then recounted being born in New York City and beginning kindergarten in Garden View before moving to Honduras for second and third grade. Javier explained that when his family moved back to Garden View he was labeled as having a low English proficiency, adding "since I speak a lot of Spanish, I have to be a newcomer." 
While each case study student had their own language learning experiences, the brief descriptions of Salvador and Javier's linguistic backgrounds demonstrate the diversity and complexity the emergent bilingual and bilingual participants navigated. I found that the interactions between these experiences and students' historical perspectives primarily coalesced around their perceptions of history and the misconceptions they articulated when discussing U.S. history. I explore each of these elements further in the following sections.

“I don't like history a lot": Student perceptions of history. The interplay between language learning and student perceptions of history became most evident in the cases of a few students identified as emergent bilinguals. For example, Yonas found the activities in Mr. Mitchell's class to be "boring" and this, in turn, informed his opinions about history:

Yonas: I don't like history a lot...sometimes it's boring, sometimes it's not boring...

Interviewer: What makes it boring sometimes?

Yonas: $\quad$ Reading books (gagging noise)... reading books is not my favorite. (interview, 12/8/15)

Yonas' negative assessment of classroom activities was a reoccurring theme. In various settings and at different points he voiced displeasure with school (fieldnotes, 8/27/15; interview, 9/15/15), history (fieldnotes, 8/31/15), and writing (fieldnotes 9/3/15; interview, 9/15/15). Yonas provided insight into his perceptions when during a notetaking activity he blurted out: “I don't understand what I'm writing” (fieldnotes, 9/18/15). The concept of "not understanding" served to provide a context for Yonas' dislike of the context, content, and procedures he encountered in Mr. Mitchell's class. 
In response to the negative experience of "not understanding" and subsequently not liking school, Yonas occasionally engaged in avoidance or resistance behaviors. In addition to his frequent verbal outbursts and occasional dancing during class, Yonas found other ways to avoid academic tasks. During one observation I saw Mr. Mitchell paging through Yonas' test before allowing him to turn it in. Mr. Mitchell pointed to the paper and said, "Don't write 'IDK' on your test," before sending Yonas back to his seat (fieldnotes, 9/30/15). Yonas employed a similar approach during our second interview when I asked him a question he apparently did not want to answer:

Interviewer: What are the three most important events in United States history? Yonas: (banging noises as Yonas gets up and walks to trash can to throw away candy wrapper)

Interviewer: What's something that happened in the United States that you think is important?

Yonas: $\quad$ Mmhmm...I don't know what to say. (interview, 12/8/15)

During this interview exchange, Yonas first physically removed himself from the table before stating simply that he did not have an answer. Yonas exhibited similar behaviors in Mr. Mitchell's classroom. Yet later in the interview, Yonas provided clarity on his experiences in Mr. Mitchell's class when he described the steps Mr. Mitchell took to help him:

Interviewer: What does Mr. Mitchell do that helps you to understand the most? Yonas: $\quad$ He read $[s i c]$ it for me.

Interviewer: Mr. Mitchell sometimes...

Yonas: $\quad$ Yeah, sometimes, if I got bored...he read it for me. Mister, I'm tired.

Interviewer: I also noticed that sometimes Mr. Mitchell would talk to you. Maybe there was a paper and he would say, "You don't have to write it down..."

Yonas: $\quad$ Yeah! (Yonas' eyes light up with recognition.)

Interviewer: Would he do that a lot or maybe one time?

Yonas: He do that sometimes. He help...if he don't have job to do-if he have job to do, he will not do it. But if he don't have a job to do, he call me: "Yonas, bring your paper here." And I say, "Okay." 
And he - and like - and I bring my paper..."You're not gonna write it, only say something." He write it for me something and I have to answer his question.

Interviewer: Right, okay. How does that help you? Why is that nice for you? Yonas: $\quad$ Because it help me a little bit, like...if I don't know some word, he help me. (interview, 12/8/15)

As described in this extended interview passage, Yonas identified the important role Mr. Mitchell played when he provided alternatives ways for Yonas to participate in and experience success in class, namely through either writing for Yonas or asking him to "only say something" about the given historical content. The significance of this type of interaction is captured in Yonas' nonverbal response- "Yonas' eyes light up with recognitions"-when I identified how Mr. Mitchell occasionally initiated these classroom interactions. Yonas' further explanation of Mr. Mitchell's "help" reinforced the mediating role that "not understanding" played in Yonas' participation in and feelings regarding the teaching and learning of history. Marisol, another emergent bilingual student in Mr. Mitchell's class, described a similar experience.

Marisol had arrived in the United States from El Salvador approximately one year prior to this study. Like Yonas, she was also an emergent bilingual who tested in the low-intermediate range on the WIDA English language proficiency assessments. Whereas Yonas articulated a dislike for school and history, Marisol primarily expressed frustration with the challenges she had "understanding" history. During classroom observations she often sought out Mr. Mitchell either by asking for help (fieldnotes, 10/6/15) or by simply stating, "Mister, I don't know. I don't understand" (fieldnotes, 10/14/15). Upon moving to a new home, Marisol left Jackson Heights and began attending Garden View Middle School on November 4, 2015. During her December interview she described having negative experiences at her new school, reporting that she 
had learned "nothing" because her new teacher "talk [sic] too much, like too fast" (interview, 12/18/15). During the interview she explained that she liked Mr. Mitchell's class and described how he had offered to help her with extra tutoring during "Period A":

Marisol: $\quad$ Me preguntaba sobre eso, si lo entendía o no.

Interpreter: He asked me about it, whether I understood it or not...

Marisol: $\quad$ Y si no lo entendía, que me dijo, me decía que lo iba a explicar mejor.

Interpreter: And if I didn't understand it, he said that he would explain it to me better. (interview, 12/18/15)

While Marisol displayed few of the avoidance or resistance behaviors that Yonas exhibited, her descriptions of "not understanding" and appreciating when Mr. Mitchell would "explicar" or explain concepts for her suggest that for these two emergent bilinguals the language learning process served to mediate their learning process and historical perspectives. The retrospective explanations of the language learning process of a third emergent bilingual in Mr. Mitchell's provide additional insights into the interaction between language learning and historical perspectives.

An immigrant from Iraq by way of Turkey, Yousuf asserted that learning English was a primary necessity for new arrivals to the United States. When describing the experiences of immigrants who entered Ellis Island, Yousuf drew on his own family's experiences, noting that immigrants "tried to learn everything over here...the language and how to drive" (focus group, 11/19/15). During the December interview, Yousuf reflected on his own language growth over the previous year. When I asked about Mr. Mitchell's history class, Yousuf explained that he liked Mr. Mitchell's class because "in sixth grade last year I sat history in the middle of the year because I was a newcomer and that was too hard and I didn't get nothing. When I came over here it's easier now" 
(interview, 12/9/15). I asked Yousuf to clarify the relationship between learning English and understanding history:

Interviewer: Do you understand more in history class now than at the beginning of the year?

Yousuf: $\quad$ Yeah because in the beginning of the year like when you come the first day of the year and of the school, you confuse what is the sharpener, what is the stuff-all that I do — but you're going to get used to it.

Interviewer: Another example of what to read, during the class focus group interview so that was when there were all of us here together, we talked about immigrants. You said that when immigrants came to the United States, they tried to learn everything such as the language and how to drive. In this example you say that immigrants learn new things; what are some things you have learned when you came to the United States?

Yousuf: When I came I know some words but not a lot, like 5 or 4 . But then they put me in newcomer and then I read English then I got some words. Then over here I went newcomer B then I went out they said I'm good, then now, yeah, I'm just trying to learn more, be better.

Interviewer: In this example when you're talking about—you said you knew just a few words?

Yousuf: $\quad$ Yeah, like 4 or 5.

Interviewer: Are you saying that you learned mostly English or mostly the language or did you also learn some other things?

Yousuf: The language. (interview, 12/9/15)

Yousuf provided specific examples of learning language (i.e., a growing vocabulary) as

he discussed the transition from a sheltered instruction class to mainstream classes, including Mr. Mitchell's history class. He identified both language learning and procedural knowledge when talking about the classroom (i.e., the pencil sharpener), much as he had when discussing the need for immigrants to learn how to speak English and drive a car. Yousuf's articulation of his own classroom experiences map onto the "not understanding" experiences of Yonas and Marisol. In order to better conceptualize the interaction between these experiences and students' historical perspectives I next 


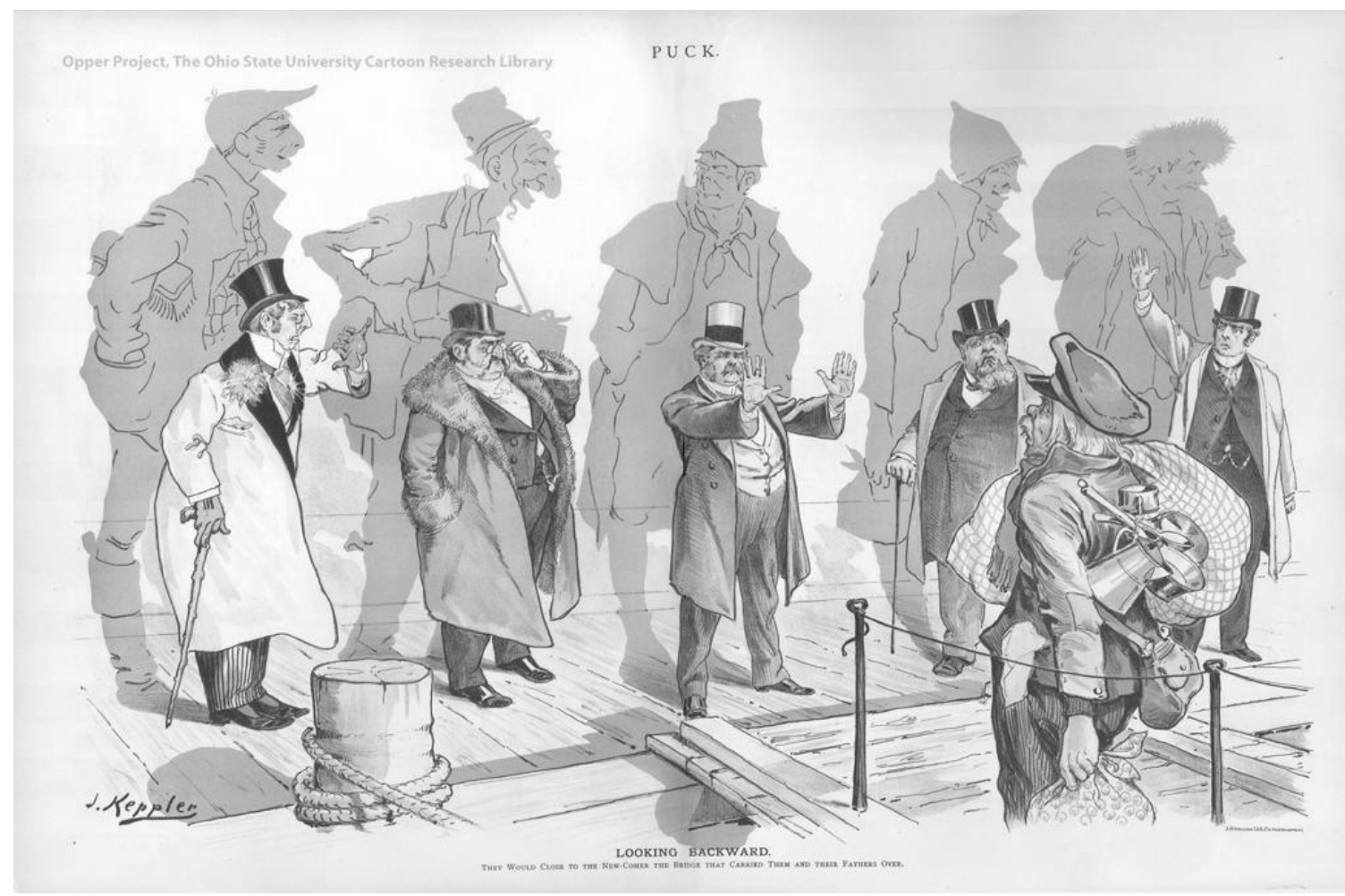

Figure 14. Anti-immigration Political Cartoon. "Looking backward: They would close to the new-comer the bridge that carried them and their fathers over." Originally published by Joseph Keppler in Puck Magazine on January 11, 1893.

present two examples of how Yonas and Yousuf engaged in historical analysis alongside bilingual peers.

In the first example, Mr. Mitchell led a class discussion to review an activity from the day before. When he asked students to describe a political cartoon (see Figure 14), the difference in the two student responses provided evidence of the ways in which language proficiency may have mediated students' historical perspectives:

Mr. Mitchell is using the digital projector to present images from the previous day's gallery walk. He asks students to "try to think...What is the message?" Maria says that the picture is about "immigrants" and elaborates, stating "No one is here that's supposed to be except for the Indians that died." Mr. Mitchell nods and says, "That's part of it—what about that guy?" "He's poor, mister!" Yonas calls out. (fieldnotes, 11/4/15) 


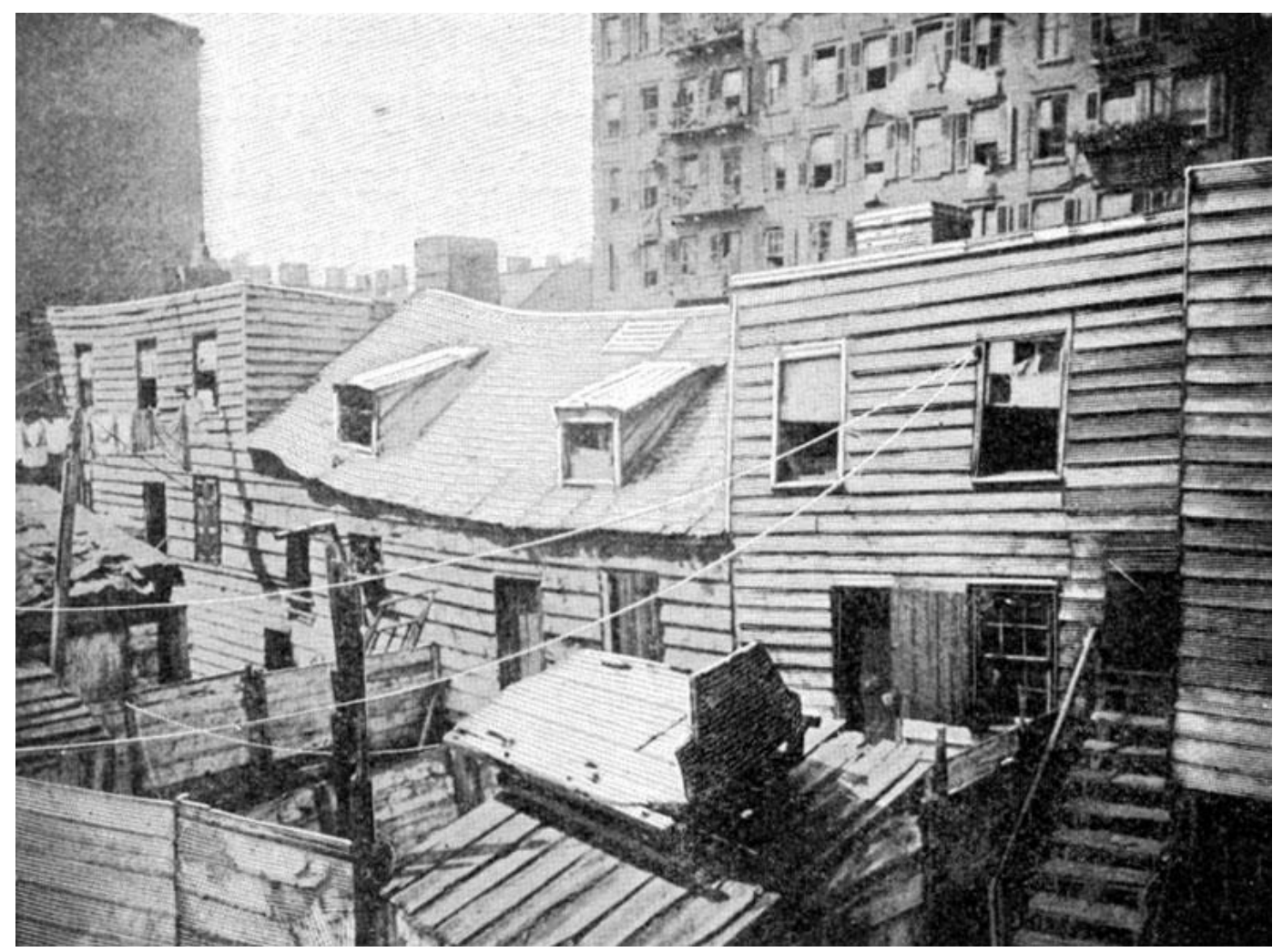

Figure 15. Five Points (New York City) Tenement Photograph.

In response to Mr. Mitchell's open-ended question, Maria provided a detailed analysis on the role of immigrants in the image and concluded that "the Indians that died" were the only non-immigrants who were "supposed" to be in the United States. When Mr. Mitchell directed students back to the image, Yonas described the character as "poor." While neither Maria nor Yonas explicitly assessed the authorship of the source they were analyzing, Maria's contextualization offered a level of detail that Yonas' response lacked. Furthermore, Maria incorporated prior knowledge through relating immigrants to Native Americans, whereas Yonas made an isolated observation on the basis of the visual evidence found within the political cartoon.

In a similar episode during the Jackson Heights focus group, the case study students in Mr. Mitchell's class examined the image found in Figure 15. When I asked 
students to identify the six most important images and explain their selections, Maria actively facilitated the process:

Maria: Well, this says: "Tenements in the big cities, such as New York." Now can you please explain what tenement means?

Interviewer: Do you know what that word means?

Maria: $\quad$ You chubby bunny...

Interviewer: Okay, be respectful...

Maria: $\quad$ Because I explained most of the things, Javier, do you want to explain what a tenement is?

Javier: (singing again)

Interviewer: Let's just look at the photograph and describe it. What do you see in this picture?

Yousuf: $\quad$ A broken house

Interviewer: A broken house! That's a great description. (focus group, $11 / 19 / 15)$

In this exchange, Maria asked Javier to describe a tenement, but when he instead continued singing, Yousuf interjected. Yousuf's short description of a "broken house" reflected the image that served to mediate the conversation, while also revealing how Yousuf's English vocabulary served to mediate the way he ascribed meaning to the image. Together, these interview and classroom exchanges provide evidence of the language learning process that the emergent bilingual participants encountered informing their perceptions of and engagement with U.S. history. In the following section I examine the misconceptions students voiced about U.S. history as another analytic tool.

"It's like a piece of cake": Historical misconceptions. The misconceptions voiced during student interviews provided further evidence of language learning mediating students' historical perspectives. Among the eleven case study students, Javier exhibited the most frequent and complex misconceptions when discussing U.S. history. While Javier's many misconceptions may traditionally be considered errors, Wills (2011) argued that "misremembering as mediated action" provides an analytic tool for 
understanding "the tools and texts that may be shaping students' representations, interpretations, and understandings of the past" (p. 142). In the case of Javier, the elaborate stories he told—while simultaneously asserting that Mr. Mitchell's class was "easy-peasy" and "like a piece of cake" (interview, 12/16/15) — suggest that he was attempting to save face or pass as a proficient student (Monzó \& Rueda, 2009). In this section I present interview excerpts that demonstrate participants' historical misconceptions and analyze them using the approach Wills (2011) suggested.

Javier's misconceptions or "misremembering" provided evidence for two primary types of "mediated action" (Wills, 2011). The first reflected a tendency to overgeneralize based on limited historical knowledge. The second indicated a limited chronological framework with which to organize historical events and actors. Two exchanges during Javier's December interview demonstrate the first mediating factor of overgeneralization. About a month after Mr. Mitchell's unit on immigration, I asked Javier to define the term "immigrant":

Interviewer: What does the word immigrant mean?

Javier: I I Ion't know. I think that it means something like something that you can follow, I think.

Interviewer: Okay. What I was thinking for the word immigrant is when somebody is born in another country and then they move to a new country. So in this case, the United States, for example. Have you learned about people who came to the United States from other countries in Mr. Mitchell's class?

Javier: $\quad$ No. I think...What's his name? I forgot his name. The one that...Martin Luther King.

Interviewer: Okay.

Javier: He was born in Africa.

Interviewer: Okay.

Javier: He moved with his family to the United States. I think that he's the only one that I learned about in history that moved to the United States. (interview, 12/16/15) 
Javier clearly did not recall the term immigrant, yet when provided with the definition he sought to apply it in a meaningful way. He appeared to then over-generalize knowledge of Martin Luther King, Jr. In his previous interview, Javier reported learning about King in fifth grade and nominated him as important because, "He made a speech that made Americans to feel bad about slavery" (interview, 9/14/15). In each situation, Javier associated King with African Americans. During the earlier interview, Javier linked King to the history of African American enslavement and thus credited King with speaking against slavery. In the December interview excerpt, Javier linked King's status as an African American to the continent of Africa, concluding that King "was born in Africa" and then — applying the definition of immigrant I had just provided himasserting that King "moved with his family to the United States." In a related example from the December interview, Javier again over-generalized based on his knowledge of race:

[Black people] helped the government to...They made the people turn around and care about people. Like Abraham Lincoln. He's one of the Black people that helped with the southern to pay attention and focus that Black people are not...They're not animals. That they should treat them like humans. Yeah. Martin Luther King, Jr....he had everybody inspired, but some White people didn't so he got shot six days before he did his speech. (interview, 12/16/15)

In this case Javier described Abraham Lincoln as "one of the Black people" based on Lincoln's initiatives to help African Americans. While these examples demonstrate the misconceptions found in Javier's historical knowledge, they also reveal a tendency to over-generalize based on limited information. I now examine two misconceptions that indicate Javier had not yet developed a strong chronological framework for U.S. history.

As the above examples illustrate, Javier perspectives on U.S. history drew heavily on the discrimination narrative and the equality narratives. In the following excerpt from 
his September interview, Javier also addressed war in his descriptions of historical significance:

Interviewer: While you're thinking about maybe if we can come up with a third person can you tell me about George Washington? Why is he important?

Javier: I forgot. Wait, no. I don't know. He's the one that you never heard about that much.

Interviewer: You said that you never heard about him?

Javier: I did but not that much. They don't talk about him no more that much in 7 th grade.

Interviewer: Okay, did you study him in 6th grade, last year?

Javier: $\quad$ Yeah, that he surrounded Robert E. Lee in Yorktown with the French and the Spanish for, I think, slavery. That he died in the disease, like gunpowder disease. (interview, 9/14/15)

In explaining Washington's importance, Javier identified the battle of Yorktown as an

important event in the Revolutionary War. Yet he borrowed the "enemy" in the person of

Robert E. Lee and the reason for fighting (slavery) from the Civil War. During the

December interview, Javier demonstrated similar "misremembering" when again

attempting to describe important events in U.S. history:

Interviewer: You mentioned some things that happened when you talked about the people. Do you think some of those events are important?

Javier: $\quad$ Yeah. I think that when George Washington and Benjamin Franklin got together in World War I, with Robert E. Lee in Yorktown when it was the last battle and Robert E. Lee surrendered and we won.

Interviewer: Okay. Who would the "we" be in that case? Who's the "we" that won?

Javier: The colonists. (interview, 12/16/15)

In this case, Javier identified "the colonists" as gaining victory over Robert E. Lee in

World War I. In his statement, Javier conflated people and events from three different wars - the Revolutionary War, the Civil War, and World War I — and three different centuries in his narrative construction. Javier's "misremembering" highlights the power of narratives to mediate students' historical perspectives, even as Javier occasionally 
demonstrated factual gaps in his historical knowledge and over-generalized particular details as he employed various narratives.

The three other emergent bilinguals discussed above also demonstrated misconceptions. Their "misremembering" followed similar patterns to Javier's misconceptions as each student conflated events or mis-attributed historical significance to particular people. For Marisol this took the form of over-generalizing the importance of holding the office of president:

Interviewer: Were there any other events that you thought of?

Interpreter: Alguna otra, algún otro evento que has pensado?

Marisol: De Mr. Martin Luther King.

Interpreter: Martin Luther King

Interviewer: So, let's say Mr. Martin Luther King is a person...

Interpreter: Entonces, Martin Luther King es una persona.

Interviewer: What do you know about him?

Interpreter: Qué sabes de él?

Marisol: $\quad$ Creo que fue presidente de Estados Unidos.

Interpreter: I think he was the U.S. president.

Interviewer: Okay. And did he do anything special or important?

Interpreter: Y él hizo algo especial o importante?

Marisol: $\quad$ No me acuerdo muy bien, pero creo que hizo mucho en la ciudad.

Interpreter: I don't remember very well, but I think he did a lot in the city. (interview, 9/16/15)

Marisol appeared to borrow from other examples of important historical figures who were U.S. presidents and then applied the title of president to King. Yonas did the reverse when he stated George Washington was important because "He's just the same as Abraham Lincoln...make electricity [sic]." Though Yonas did not name Benjamin Franklin during his interview, other students did, which suggests that Yonas may have “misremembered" Lincoln and Washington's shared role as U.S. presidents with Franklin's iconic tale of being struck by lightning while flying a kite. Finally, Yousuf "misremembered" the origin story of the United States, specifically the countries 
involved: "When England, Christian [sic] Columbus, when he saw the United States and then France and Mexico, they fought to get this country for them" (interview, 12/9/15). In Yousuf's telling, Columbus sailed on behalf of the British, subsequently fighting France and Mexico. His "misremembering" reflects the role of over-generalizing historical knowledge as Yousuf appears to draw on the roles of both England and Columbus in the nation-building narrative without adequately separating them in time and space.

While these examples of misconceptions voiced by emergent bilinguals provide important evidence of the mediating role language learning played in the formation of historical perspectives, emergent bilinguals were not the only participants who engaged in "misremembering." During his December interview, Gebre named the Civil War as an important history event in U.S. history, but then described the Revolutionary War as he explained his selection:

Because both Civil War that connected ... George Washington was in there. That connected how they broke from Britain and all of those things and how they didn't have to ... They went through a lot of stuff there and they went through a lot of stuff and they had to go through tons of battles and people died. We learned about that a lot in class last year and we learned about that this year too and World War I because that connected to World War II. There were three world wars. Actually, they were both I think World War II, the Pacific and the one Pacific World War. World War I and World War II in Europe. (interview, 12/8/15)

At the close of his statement, Gebre asserted that other wars were also important. He described the fighting in the Pacific theater during World War II as a separate war from "World War II in Europe," which led him to conclude that there had been "three world wars." In this excerpt, Gebre employed the nation-building narrative when he attributed historical significance based on war and the struggle to create the United States even as 
he "misremembered" the particular historical events and actors. In a related example, Aras used the equality narrative to explain his selection of George Washington:

Aras: $\quad$ George Washington.

Interviewer: Okay. And what do you know about George Washington?

Aras: $\quad$ He fought against the South, about slaves.

Interviewer: If he fought against the South, who is he a part of?

Aras: $\quad$ The Union. (interview, 12/9/15)

In this exchange, Aras appeared to "misremember" Washington's historical role and attributed Lincoln's role in fighting the Civil War to Washington. Aras named the fight "against the South" as being "about slaves." As such, he identified the value of equality as the primary rationale for historical significance.

These examples of the participants' "misremembering" suggest that the interaction between language learning and historical meaning making is complex. The emergent bilinguals did provide more evidence of "misremembering" in their descriptions of U.S. history. However, the examples of Aras and Gebre's "misremembering" suggest that students at various stages of English language development "misremembered" historical knowledge. As such, given the various ways Marisol, Yonas, and Javier chose to voice or hide their "not understanding" in the classroom and during interviews, the possibility remains that students labeled as bilingual may have simply learned to negotiate the school context and thus more successfully hid their misconceptions. I next examine the interactions between the participants' social context and their historical perspectives.

\section{Social Context}

While students voiced different views on the relationship between the present and the past, many of the participants demonstrated connections between their understanding 
of contemporary society and their historical perspectives. The U.S. social and political context during the fall 2015 months clearly seeped into the classroom and became a part of the discourse around U.S. history, particularly for those participants who were Latino or Muslim students from immigrant families. While I examine some of these specific aspects of students' identity more fully in subsequent sections, in this section I focus on the ways in which the link between students' historical perspectives and their social context could be found principally in how they applied the discrimination narrative to both U.S. history and current events.

Felix provided a particularly clear example of the potential for social context to influence students' historical perspectives. Often soft-spoken, Felix was the only emergent bilingual in Ms. Rogers' class to consent for this study. During the December interview he introduced the topic of tolerance while describing a recent discussion in Ms. Rogers' class:

Interviewer: What have you learned in Ms. Rogers' class that surprised you? Felix: $\quad$ Tolerance. Interviewer: What does tolerance mean? Felix: $\quad$ You're ... I can't say the same word.

Interviewer: Well, you can say it and then you can explain what you mean. Felix: $\quad$ You're...I mean, you do care but you don't really listen to it or make a whole bunch of stuff like when somebody is being racist to you, you don't really care.

Interviewer: Okay. Are you talking about this in Ms. Rogers' class or in the bullying class?

Felix: In Ms. Rogers' [class].

Interviewer: Okay. Are there some examples or situations from history that she is connecting it to?

Felix: $\quad$ She is connecting it to Donald Trump.

Interviewer: Okay. When you talk about somebody being racist and how you respond to that, is Donald Trump the example of how you respond or the example of someone being racist?

Felix: Racist.

Interviewer: Have you thought about or learned specific examples or specific things you might do that would be an example of tolerance? 
Felix: $\quad$ This kid tried to get me in a fight. I really didn't. I didn't want to, to get in trouble.

Interviewer: Okay. With this example of Donald Trump, does Ms. Rogers talk about Donald Trump needing to be tolerant or is it more about how we need to be more tolerant of Donald Trump?

Felix: $\quad$ He needs to be tolerant.

Interviewer: Okay. How would we know if he was being tolerant? What would he say or do that would...?

Felix: Right now, about he wants to get rid of all the Muslims. I mean, not all them are terrorists.

Interviewer: Is the comment saying that we should get rid of Muslims, is that tolerant or the opposite of tolerant?

Felix: $\quad$ The opposite. (interview, 12/15/15)

In the course of explaining what tolerance meant, Felix identified Donald Trump, a business man and Republican presidential candidate, as a counter-example. Felix pointed specifically to Trump's comments from about a week before the interview in which Trump advocated "getting rid of Muslims," which Felix described as "the opposite" of tolerance. In the process, Felix argued that Trump needed to be more tolerant of others. Felix also reported on a situation in which he had chosen to be tolerant when someone "tried to get me in a fight" because he did not want "to get in trouble." In this exchange, Felix described examples from personal interaction and current political events that reflected ways in which the discrimination narrative extended into the present based on a contemporary example.

Later in the same interview, I returned to the concepts of racism and tolerance in order to investigate how Felix might draw on current events to challenge or reinforce the role of discrimination in U.S. history. Through his response, Felix demonstrated the potential for social context and historical perspectives to inform understandings of both concepts:

Interviewer: When we were earlier using the word racist, we talked about in the past, the KKK, and more recently, Donald Trump. Do you feel like 
Donald Trump is representative or that he is normal in how he talks about people?

Felix: $\quad$ Not really, he doesn't...He should think before he speaks.

Interviewer: Okay.

Felix: $\quad$ Because he doesn't know, some people are nice. He is probably KK....His family members are probably, his ancestors...

Interviewer: Just to make sure I understand you, you're linking that his ideas are similar to the KKK and saying that maybe even his family was connected to...?

Felix: I mean, he is pretty much like Hitler because Hitler didn't like some sort of people.

Interviewer: You pointed out that the KKK was a group. In this example, Donald Trump is one person. That was a difference. Would you be concerned that if Donald Trump could do whatever he wanted, that he would do things like the KKK did, that he would not only talk about people, but he would hurt people?

Felix: $\quad$ No.

Interviewer: No? When we think about the comparison with Hitler then, you're saying they talk about people, like they seemed to have some similar ideas. What do you think that Donald Trump would also do things like Hitler did?

Felix: $\quad$ Yup.

Interviewer: Okay.

Felix: $\quad$ Well, not kill people but...

Interviewer: Not kill people.

Felix: He'll try to make all the Hispanics, all the Muslims get out of this country. (interview, 12/15/15)

In this exchange, Felix compared the prejudicial and discriminatory views identified with the KKK and Hitler to his accounts of Trump's rhetoric. Though Felix drew a distinction between the violent tactics of the KKK and Trump's rhetoric, he asserted that Trump "is pretty much like Hitler because Hitler didn't like some sort of people." Felix concluded that Trump would "try to make all the Hispanics, all the Muslims get out of this country," a form of ethnic purging in line with the ideology if not the methods of the historical figures to which he had compared Trump. In his analysis, Felix demonstrated his own sense making of both historical events and his contemporary world. Drawing on the KKK and Hitler as embodiments of discrimination, Felix applied these lessons of history 
in a nuanced way, at first conjecturing that Trump's racist ideology may be indicative of "his ancestors" having been in the KKK, but then revising this literal assessment of biological lineage to focus on the message Trump had conveyed.

A few other participants offered similar analysis of Trump's public statements. For example, Felix and Santiago demonstrated the personal relevance of Trump's statements during the focus group when they argued that discrimination had existed in both the past and the present:

Santiago: I think it's kind of both

Felix: $\quad$ Yeah, it's both, cuz you see Donald Trump right now...

Interviewer: Uh-huh...tell me more about - I mean, I certainly know who Donald Trump is, but tell me more about what you're thinking. Santiago: He's being really racist to Hispanics, especially Mexicans. He says he's going to deport...

Felix: $\quad$ All of them-he's funny!

Interviewer: Like funny in a good way or funny in a bad way?

Felix: $\quad$ In a bad way

Santiago: $\quad$ Funny in a DUMB way

Felix: Really dumb way!

Santiago: He's so dumb.

Felix: $\quad$ How you going to deport like...

Gebre: $\quad$ ALL the Mexicans?

Aras: $\quad$ Exactly! (focus group, 11/24/15)

As Santiago and Felix engaged in this exchange, their positionality as self-identified "Mexicans" and the impact of social context became apparent. However, other participants assessed history differently based on a similar understanding of current events:

Interviewer: What you're describing NOW in terms of how people stereotype, how people are racist, have you learned that this is the SAME as it has been in the past - that it's the same as it was in history-or that it's different? So if you would say it's the same put your thumb up or if you would say it's different put your thumb down. What would you say?

Salvador: I would say different because like some people like back then were nicer than they are today. 
Interviewer: Ok and Aras you have yours up. Salvador, you have yours up. Sorry, Felix, sorry. Gebre, you have yours down.

Gebre: I'd say it's not the same because some people, most people are nicer now. I think because...

Interviewer? Nicer now you said? So before you think it was actually worse?

Gebre: $\quad$...because they discriminate Blacks and Spanish even more...and then I think now that people think that you can't discriminate someone just from their color - that you don't have to talk to them, but you don't have to be racist to them either.

Interviewer: Gotcha. And Salvador, sorry! Santiago-I'm using your name for everybody. How do you have your thumb? Are you up-it's the same - or down? Or are you in the middle? I'm a little confused.

Santiago: In the middle

Interviewer: In the middle, okay. And in one minute, why are you in the middle?

Santiago: Because like it kinda has been a little better cuz you don't really hear people talking as much about - they used to really hate Asians and Africans and now they don't really say anything. Now they're even doing business with Asians. And you see Asian workers that are even getting more money than some White people.

Interviewer: Okay.

Santiago: And also bad because how they're like mistreating all the people are Arabic just cuz of ISIS they think all the Arabics [sic] are terrorists when they're really not and you just don't know about it. And they just say that because they want to. (focus group, $11 / 24 / 15)$

In this extended focus group exchange the participants described different historical perspectives as mediated by their shared social context. Salvador first argued that discrimination had been more prevalent in the past. Gebre countered this when he asserted that "most people are nicer now." Santiago balanced these two perspectives and concluded that the context was "a little better" for some groups while others continued to be "mistreated." Aras made a similar assessment when asked to compare his current positionality to his perspectives on U.S. history:

Interviewer: Do you think people would have been nice to you and your family if you lived in the United States in the past?

Aras: $\quad$ I'm not really sure, but I mean, there's still a lot of racist people that's in now.

Interviewer: Okay. There's some of the same problems in history and currently? 
Aras: $\quad$ Yeah. (interview, 12/9/15)

While students voiced different views on the relationship between the present and the past, many of them demonstrated connections between their understanding of contemporary society and their historical perspectives. As the examples above demonstrate, these discussions were particularly prevalent among the five male participants in Ms. Rogers' class and were also closely related to various aspects of students' identity. In the following section, I examine the intersection between participants' historical perspectives and notions of racial and ethnic identity.

\section{Racial and Ethnic Identity}

The participants regularly employed the discrimination narrative when discussing notions of racial and ethnic identity. Phenotype and language served as the primary markers of racial and ethnic identity for the case study students. Specifically, students employed the racial construct of "being Black" and the ethnic term "Hispanic" in classroom observations and student interviews. In this section, I first examine student discourse around skin color and racism. I next describe the connection between language use and ethnic identity. I then describe the ways in which students applied these concepts in their historical perspectives.

“That's racist!": Racism and discrimination. Data analysis revealed that participants' frequent use of the term "racist" could either encompass any mention of race or serve as shorthand for the broader notions of discrimination or inequality. While students in both classes discussed examples of racism in U.S. history and current events, racialized discourse was particularly prevalent in Mr. Mitchell's class. For example, during one observation Mr. Mitchell showed students a six-minute video clip during a 
lesson on the passage of the 13th, 14th and 15th amendments to the Constitution. When a scholar being interviewed for the camera stated that the purpose of the 14th amendment was to promote "due process," the speaker stipulated that "the courts don't make any distinctions about us, whether we're rich or poor, White or Black, male or female." Javier turned slightly in his chair and snapped, “That's racist!" (fieldnotes, 9/11/15). In this situation, Javier labeled the mention of "White or Black" as being "racist" even as the speaker was defining the legal protocol intended to fight racism and other forms of discrimination. Javier's comment revealed a discomfort with using racialized terminology and contributed to the following analytic note in my fieldnotes for that day: "[AN: There seems to be a real focus on the personal. While there is a growing awareness of societal or group characteristics (i.e., racism, color, language) these are not yet evident in the history students are learning]" (fieldnotes, 9/11/15). At this point in the semester, Mr. Mitchell had completed a review unit on U.S. geography and was two days into a unit on Reconstruction. In order to further explore how students' views on race may interact with their historical perspectives, I next examine how Javier and two of his fellow participants in Mr. Mitchell's class-Maria and Yonas-frequently demonstrated "a growing awareness of societal or group characteristics" related to their use of the term "racist" and then broaden the analysis to include how other participants incorporated these notions.

“We're the Hershey family": Javier and skin color. The case of Javier provides an example of a student who discussed race and skin color regularly. A self-identified “comedian/class clown” (interview, 12/16/15), Javier generally displayed a jovial, friendly demeanor in Mr. Mitchell's class. While Javier rarely used the terms "African 
American" or "Black," he frequently made references to "chocolate" during class, at times simply stating "I'm chocolate" (fieldnotes, 9/3/15, 9/11/15), and at other times using more extensive and elaborate utterances: "Mister, can I have a chocolate bar? I have a disease that I need to eat chocolate...chocolate milk...chocolate chicken...chocolate banana...psyche!" (fieldnotes, 10/22/15). The U.S.-born son of Honduran immigrants, when asked to describe himself, Javier stated that he had "like kind of dark skin color" (interview, 12/16/15).

Javier also discussed skin color when talking to or about Mr. Mitchell in class. In one of the first references to Mr. Mitchell's race or skin color, Javier denoted the topic of skin color by talking about "Hershey" and then used the term "family" to signal that he thought he and Mr. Mitchell had similar skin color:

Mr. Mitchell tells students to get their notes sheet out. Javier calls out, "We're the Hershey family.” Mr. Mitchell quickly retorts, "No, we're not the Hershey family. We might be the Hershey color, but we're not family." (fieldnotes, $10 / 6 / 15)$

In this classroom exchange, Mr. Mitchell outwardly accepted the analysis of their shared skin color- -we might be the Hershey color"-but directly rejected the use of the term "family" and the related associations of similarity. During an observation a week later, Javier again used the imagery of chocolate to allude to skin color:

12:55 Mr. Mitchell writes up on his projected copy of the notes: "Custer miscalculated and ran into over 2,000 troops. All of his men were killed." Javier is talking quietly and says something about "chocolate." (I can't hear what else he is saying.) Maria is sitting directly in front of Javier and says, "Stop being racist!" "But it's true," Javier continues. "We are the chocolate crew." (Javier gestures to Mr. Mitchell who is now standing nearby.) (fieldnotes, 10/13/15) 
In this excerpt Javier talked to his classmates about his perception of having something in common with Mr. Mitchell. In response, Maria called Javier's utterance "racist" in an apparent attempt to silence him. In a final example, Mr. Mitchell was correcting Yonas when Javier interjected and addressed Mr. Mitchell as "Mr. Brown":

Yonas calls out to Mr. Mitchell, "Miss, you..." Mr. Mitchell walks toward him and says, "My name is Mr. Mitchell all day, every day." Javier calls out, "Mr. Brown." There is an audible groan. An unidentified student yells, "That's racist!" (fieldnotes, 10/26/15)

This time an unidentified student — most likely not one of the case study students—used the term "racist" to silence Javier. This indication of disapproval could have been in response to Javier's overt reference to skin color through the use of the term "Mr. Brown” or could have been in response to Javier's choice to interrupt Mr. Mitchell by calling him "Mr. Brown" while he was in the middle of telling Yonas to call him "Mr. Mitchell." In either case, Javier's exclamation clearly fit within a pattern of discussing Mr. Mitchell's skin color.

Given the pattern of Javier's racialized comments, I selected the following example from the fieldnotes to discuss with him during the December interview. Javier again used language specific to skin color in his response:

Interviewer: "Javier makes a comment about liking chocolate. He walks over to Mr. Mitchell and says that they are chocolate brothers. While he is still at the front of the room, Javier says that he wants to teach the class about himself, explaining that his family is chocolate and caramel." In this example, you say that you are chocolate. How would you describe yourself?

Javier: $\quad$ Like kind of dark skin color.

Interviewer: Okay.

Javier: Curly hair and midget, like the minions.

Interviewer: Midget like the minions. What does being a midget mean?

Javier: Like, small.

Interviewer: Small. But not yellow like the minions.

Javier: No. 
Interviewer: What does it mean to be chocolate or caramel?

Javier: I'm the only dark skin colored one. My mom is light. Not that light, but like this...my sister and my brother.

Interviewer: Your sister and your brother are what?

Javier: $\quad$ Same thing as my mom's skin color.

Interviewer: Oh, okay. What does the word caramel mean in that case?

Javier: I don't know how to explain it. Let's see...

Interviewer: You're thinking of a color?

Javier: $\quad$ Yeah, like a skin color.

Interviewer: So it would be something that would be different from chocolate.

Javier: $\quad$ Mmhmm (affirmative).

Interviewer: Would it be just the same as White or is it not White. Not the color white, but when people say...

Javier: $\quad$ Yeah, like a White person. Like a White Hispanic guy.

Interviewer: White Hispanic. You described Mr. Mitchell as your chocolate brother. What does that mean?

Javier: $\quad$ Same skin color and making fun of - - like twins.

In this extended interview exchange, Javier explained the typology of skin color reflected in his classroom discourse. As the "only dark skin colored one" in his family, Javier distinguished his own skin color from that of his mom and siblings. Javier asserted that rather than having "caramel" skin color "like a White Hispanic guy," his "chocolate" tone made him more similar to Mr. Mitchell. Javier concluded that he and Mr. Mitchell had the "same skin color" and were "like twins." As such, while Javier had used the term "racist" to silence others—and had been silenced in the same manner-Javier demonstrated that skin color served as an important source of self-identification, as well as a potential source of belonging or kinship. As such, he openly talked about "skin color" even though his peers' repeatedly attempted to brand such discourse as "racist."

"I'm not black; I'm dark brown": Yonas and discrimination. Compared to Javier, Yonas primarily resisted references to skin color or race—particularly the term "Black"- labeling such discourse as "racist." An immigrant who self-identified as both Eritrean and Ethiopian, Yonas appeared to draw a distinction between himself and the 
"Black American[s]" that he credited Abraham Lincoln with helping (interview, 9/15/15).

At the end of Mr. Mitchell's class one day students are milling around as they wait for the bell to ring. Javier jokes that he is "not White—I'm Black." Yonas calls out: "Ohh!

That's racist!" He then holds his wrist in his hand and announces to no one in particular, “I'm not black; I'm dark brown." (fieldnotes, 10/23/15). Such a distinction reflected the complex relationship between the concepts of race and skin color found in Yonas' utterances, which in turn influenced Yonas' use of the term "racist."

For Yonas, the term "Black" connoted historical significance particularly related to the racial discrimination found in U.S. history. While Yonas rarely used the term "African American" outside of the formal interview setting, he did use the terms "African Americans" and "Black Americans" as synonyms in response to interview prompts. When he selected the "African American" descriptor card during his December interview, Yonas made this connection explicit without directly applying either term to himself:

African American...some White man-like the American, they're racist to the Black American...that's why I don't like them. Not-I like them now, not before- like my dad told me a lot of stories. (interview, 12/8/15)

Yonas drew parallels between the terms "African American" and "Black American," as well as the terms "White man" and "American." Yonas added that his dad told him about personal experiences with the KKK, suggesting that the "stories" Yonas attributed to his dad actually reflected Mr. Mitchell's instruction rather than his father's lived experiences. In his September interview, Yonas had referenced similar concepts, specifically identifying them within Mr. Mitchell's instruction: “I watching in Mr. Mitchell's classthe bad people - the African American, they make them do anything they want...cuz that 
makes me sad a lot of time" (interview, 9/15/15). In both cases, Yonas identified the treatment of African Americans as an important component of his historical perspectives without explicitly defining himself as an African American.

When I asked Yonas to explain his selection of the descriptor "African American" during the December interview, he referred to the history of racial discrimination presented in class. Again, rather than using the card as a self-identifier, Yonas described the historical treatment of African Americans:

Interviewer: There was one more that I didn't ask you about. African American - why did you choose the word African American?

Yonas: $\quad$ Um... a long, long time, like the American - they mean to African American. Why is the question?

Interviewer: Okay.

Yonas: Why they don't like Black American?

Interviewer: Well, what would be - that actually looks at our first, the next question I want to ask you-So, what have you learned about so far this year in Mr. Mitchell's class? Did you learn about how some people treated Black people?

Yonas: $\quad$ Mmhmm. (affirmative) And we learned today, um...mmm...I don't know how to call it. Like the White people...like they-they don't like if Black people talk, they walk away.

Interviewer: Walk away? So they're just—why did they walk away?

Yonas: $\quad$ Maybe they don't like Black Americans.

Interviewer: Okay, it's just like to be mean - to say, "I don't care?"

Yonas: $\quad$ Mmhmm. (affirmative) (interview, 12/8/15)

In this interview exchange at the end of the semester, Yonas framed the mistreatment of African Americans as something that happened "a long, long time" ago. He characterized the discrimination as a matter of "White people" not "liking" African Americans and provided the example of a White person "walking away" from a Black person. Yonas' selection of the "African American" card and subsequent explanation of historical discrimination of African Americans demonstrated the prevalence of this narrative within his historical perspectives. 
In response to the negative connotations related to race in U.S. history that marked Yonas' historical perspectives, Yonas rejected the use of the term "Black" as "racist" in contemporary contexts, using it only to refer to African Americans- - Black Americans"-in U.S. history. Even then, Yonas was cautious. For example, Yonas specified that he was not being "racist" when describing Martin Luther King, Jr. as Black: "He's Black—I'm not being racist. Ya know what I mean?" (interview, 12/8/15). When I presented Yonas with an excerpt from the fieldnotes in which Javier described being "chocolate brothers" with Mr. Mitchell, Yonas replied:

[Javier] all the time talk about "chocolate, chocolate, chocolate." I say, "I don't like chocolate." And I don't like chocolate-I like vanilla better than chocolate. And he said, "Why you don't like chocolate? I'm a chocolate brother." And I'm like, "Oh my god, I'm not your brother." I say that. He say that I'm light brown and I say that I'm a little bit, not dark brown, I'm a little bit dark brown - he say that I'm a chocolate, I say, "Oh my god, leave it alone-leave me alone." He talk a lot chocolate and I HATE chocolate. (interview, 12/8/15)

Yonas' response revealed his attention to three components of Javier's ongoing remarks about "chocolate." Yonas first asserted that he did not like to eat chocolate, naming vanilla as his preferred flavor. Yonas then echoed Mr. Mitchell's rebuttal to Javier, arguing that he did not want to be considered Javier's "family" or "brother." Finally, Yonas explicitly addressed the concept of skin color, describing himself as "a little bit dark brown." Later in the interview Yonas explained that in class he had disputed Javier's claim that Yonas was Black, arguing, "I am not dark black." When I asked Yonas what it meant to be "Black," he labeled the term "racist" and explained how calling someone "Black" might lead to violence:

Interviewer: What does it mean to be Black? What does that mean? Yonas: That's racist if somebody call you Black and all that — punch his nose. I will punch his nose. (interview, 12/8/15) 
Yonas conceptualized the term "Black" as "racist," fitting into a larger category—which included unknown insults captured in the "and all that" utterance-related to historical discrimination. Yonas punctuated the seriousness of the term by threatening to "punch his nose" if someone called him "Black." I followed up this exchange by asking Yonas whether he considered people from his native Eritrea to be "Black." Yonas stated that in Eritrea people had "my skin" color (interview, 12/8/15). Yonas then distinguished between those people who had "my skin" and the people that he learned about in the context of U.S. history:

Interviewer: In Mr. Mitchell's class-do you learn about people who are Black or brown or different colors?

Yonas: $\quad$ No-we learn about Black, NOT brown. (chuckles)

Interviewer: You talk about Black, but not brown?

Yonas: $\quad$ Mmhmm (affirmative)

Interviewer: Would you call Mr. Mitchell Black or brown?

Yonas: I never call him Black.

Interviewer: Well, I'm sorry, not that —okay, let me say it in another word-Do you THINK that Mr. Mitchell is Black or would you think he is brown?

Yonas: $\quad$ He is kind of my color (Yonas, 12/8/15)

When I asked Yonas to describe Mr. Mitchell, Yonas again rejected the use of the term "Black" when talking about a person he knew personally. His quick response and raised voice suggested a defensive stance as though he felt accused of being "racist" when he asserted, "I never call [Mr. Mitchell] Black." As he had when asked to label the skin color of people in Eritrea, Yonas compared Mr. Mitchell's skin color to his own rather than using the term "Black" or "brown."

In short, Yonas demonstrated a conceptualization of the term "racist" as connoting the discrimination faced by "Black Americans" in the "long, long ago" past. As such, Yonas primarily rejected the term "Black," referring to himself and others who 
he identified as having a similar skin color as "dark brown." While Yonas displayed consistency in this regard, his classroom interactions also revealed a complex relationship between skin color and the concept of being "racist." The following excerpt exemplifies how Yonas occasionally joined in racialized discourse in order to provoke a laugh:

Mr. Mitchell is sitting in the back of the room with BF and reading. Javier is sitting on a stool by Mr. Mitchell's desk. Javier says, "You're like chocolate chip." Yonas calls out, "I'm White." His exclamation draws laughter. (fieldnotes, 10/6/15)

At other times, Yonas displayed the "Oh my god, leave it alone" annoyance he conveyed in the December interview:

1:18 Javier asks loudly, "Mister, can I have a chocolate bar? I have a disease that I need to eat chocolate." Yonas yells over, "You're racist!" Javier babbles on about "chocolate milk...chocolate chicken...chocolate banana" before shouting "psyche!" (fieldnotes, 10/22/15)

In such exchanges, "You're racist" served to convey irritation and silence Javier as discussed in the previous section. Thus, Yonas employed the term "racist" to signal extreme disgust - "I will punch his nose"-when contemplating historically-based discrimination, as well as to engage or silence peers during racialized classroom discourse. In the next section, I examine the case of Maria, a student for whom the term "racist" appeared less personal.

“That's messed up!”: Maria and inequality. Though Maria frequently identified instances of discrimination or inequality encountered in the course of Mr. Mitchell's U.S. history instruction, Maria principally used the term "racist" to silence peers during racialized social interaction. In contrast to Javier and Yonas, Maria did not refer to skin color when talking about herself. Instead, Maria referenced her family background and linguistic experiences when describing herself during her September interview: 
I chose Cuban because my step-dad, even though I call him Dad, is Cuban. It's part of my heritage. I chose Honduran because my mother is Honduran. I chose American because I am American and I was born in this country. I chose bilingual because I talk English and Spanish. (interview, 9/17/15)

A self-described “comedian/class clown” (interview, 12/14/15), Maria answered questions and offered commentary during Mr. Mitchell's instruction more than any of her classmates.. Many of Maria's frequent classroom comments addressed inequality or discrimination with race providing one area of critique. In one case, Maria was flipping through the textbook at the end of class:

Maria is looking at the cover of her textbook. She asks Mr. Mitchell if the picture of Martin Luther King, Jr. is a real photo. Mr. Mitchell says it is and Maria argues that they didn't have color pictures. Mr. Mitchell responds that they did have color photos. Maria then opens the books and yells, "That's messed up." She loudly describes how there is a sign that says "Help Wanted-Whites Only" and a Black man standing beside it. She says she would "kill someone" if she saw that. She immediately flips to another page and asks Mr. Mitchell about children working, asking him to confirm that they "got paid, right?" Mr. Mitchell says that the children did not get paid very much and that they did dangerous work. (fieldnotes, 8/28/15)

In this field notes excerpt, Maria explicitly identified examples of unequal treatment and pointed them out to Mr. Mitchell. Yet even when the "Help Wanted—Whites Only" sign directly denoted race, Maria did not use the term "racist," but instead pronounced, “That's messed up!” In another representative example, Maria verbally noted her response during a video clip on the treatment of Native Americans following the Civil War:

1:06 The focus shifts to Native Americans who have been "separate - isolated remote" due to federal policy. Sheryl Crow states that "We came here and confiscated their homeland....." The narrator explains how Custer attacked 7,000 Native Americans with his 700 troops at Little Big Horn, adding that while Native Americans "win the battle, they will lose the war." "That's bad," Maria says. Dan Rather concludes that "Wounded Knee is a great scar on the American landscape." As there is a transition in the video, the substitute teacher calls out to 
the class: "There's a book about Black Elk...it's worth reading." (fieldnotes, $10 / 5 / 15)$

Maria again labeled the injustice she saw, stating, "That's bad." In a similar response during a video on immigration, Maria called out "That's rude!" when the narrator described "racial and ethnic tensions" (fieldnotes, 10/27/15). During these regular outbursts, Maria consistently used terms other than "racist" when discussing the examples of racialized discrimination found in the academic content.

By contrast, Maria did employ the term "racist" when engaging with classmates in social interaction. During these exchanges, Maria used "racist" to silence others when they talked about skin color. While these exchanges most frequently occurred between Maria and Javier, they occasionally included other peers:

Yonas is sitting in the isolation desk. He looks around the room and then leans forward such that he is out of sight behind the filing cabinet. BC seems to be talking to Maria. "I'm not freakin' Black," he says as he rubs his bare arm. "I'm brown!” “That's racist!” Maria grins. (fieldnotes, 9/4/15)

Maria's grin suggested she was playfully interacting with $\mathrm{BC}$, who later explained to Maria that his mom is from Hawaii and his dad is "mixed" (fieldnotes, 10/7/15). During this racialized discourse Maria appeared inquisitive and at ease. When engaging with Javier, however, Maria's banter often sounded more strained and cutting:

Maria snaps at Javier about "being racist to yourself-that's like calling yourself caramel!" Javier smiles and says, "I love caramel, especially on my ice cream." (fieldnotes, 10/9/15)

In this exchange Maria "snapped" at Javier about "being racist" in a tone of voice that suggested she felt uncomfortable or annoyed. In sum, Maria appeared to use more general terms of disapproval when faced with historical examples of discrimination in 
U.S. history, reserving the term "racist" as a silencing tactic when interacting with peers, particularly Javier.

Through cross-case analysis of Javier, Yonas, and Maria, I found that all three students silenced peers involved in racialized classroom discourse by labeling the conversation or classmate "racist." While the racialized students that these three students used was not representative of the other participants, they provide conceptually rich examples of what the common term "racist" may mean in their context. Javier most regularly initiated interaction on the topic of skin color and thus was more frequently on the receiving end of Yonas and Maria's efforts to silence him. In response to examples of discrimination in Mr. Mitchell's U.S. history instruction, Maria's utterances of disapproval rarely included the term "racist," while Yonas signaled his resistance to historical racism through rejecting the term "Black" as a marker of race-based historical discrimination. In the following section, I examine the link between student language use and ethnic identity.

"You speak Mexican": Language and ethnic identity. In addition to referencing physical characteristics, students also occasionally named language use as an indicator of ethnic identity. While students often appropriated terms like "Hispanic" when referring to themselves, the frustration Felix voiced about being mis-identified or labeled by others represented a more typical exchange:

Felix: $\quad$ I don't get how people say, "You speak Mexican.” I mean, Mexico is not the only country that speaks Spanish.

Interviewer: Okay. Could you say more about who the "some people" are? And who the "we" is in your statement? You had said you were asking Ms. Rogers, "Why do some people say that we speak Mexican?"

Felix: $\quad$ Kids that are...they're Hispanics. Some kids say to us, like the Hispanics, that we speak Mexican.

Interviewer: You're thinking mostly about students or people your age? 
Felix: $\quad$ Yeah. (interview, 12/15/15)

Born in the United States to Mexican immigrants, Felix selected the "Mexican" card during both interviews and in the exchange above identified himself as "Hispanic." As such, Felix did not attempt to hide his heritage, rather his annoyance reflected the misapplication of such terms related to ethnicity and language. Expressing his frustration with people saying that he and other Hispanics "speak Mexican," Felix asserted that many people speak Spanish and thus speaking Spanish, being Hispanic, and being Mexican should not be treated as interchangeable. While grouping all Hispanics together irritated Felix, his comments suggest that ethnicity and language were closely related. An exchange involving Maria and a few Latina/o classmates revealed a similar understanding:

Maria asks if Antonio and BD are cousins. Antonio says that they are "just friends." Maria turns to BD and asks if she is "Hispanic." BD replies, "Yes, but I don't look like it, do I?" Maria shakes her head no. BE chimes in-“sort of," adding, "I don’t speak español." (fieldnotes, 9/2/15)

In this peer interaction, students informally defined what it means to be "Hispanic" through discussing how to apply the term to individual students. In their discussion, being Hispanic was marked by both physical appearance and language. At first Maria asked two Hispanic students, Antonio and BD, if they were related. When Antonio explained that he was not related to BD, Maria asked about BD's ethnic identity in an effort to categorize her. In response, BD asked Maria if she thought that BD looked Hispanic. When Maria responded in the negative, BE, a non-Hispanic female student, interjected that while she might look Hispanic, she did not speak Spanish. Through this exchange, Maria and her peers linked ethnic identify to both physical traits and linguistic ability. 
Yonas also demonstrated the link between linguistic knowledge and ethnic identity, speaking Spanish with increasing frequency as the semester progressed in an apparent effort to fit in with his peers. For example, during the Jackson Heights focus group Yonas told fellow students to "mira/look" at a particular image and then following up on one of Maria's questions by asking, "Si or no?" (focus group, 11/19/15). During his December interview, Yonas even stated that his dad was from Honduras (interview, 12/8/15). Through the labels students used, rejected, and sought, the role of language as a marker of ethnic identity became apparent. In the next section, I examine how students' understanding of race and ethnicity interacted with their perspectives on U.S. history.

"It's like Black and White": Perspectives on historical racism. While students demonstrated complex notions of racial and ethnic identity, their discussion of ethnic and racial constructs within U.S. history revealed a binary perspective consisting primarily of "White" and "non-White" historical actors. Though students named the systemic racism perpetrated against African Americans, Native Americans and Chinese immigrants as part of the discrimination narrative, they primarily identified historical actors and events that reflected a narrative with primarily White protagonists. When confronted with this fact in their December interviews, many participants named African American historical figures. For example, Salvador acknowledged that many individuals in U.S. history were White before providing three Black counter-examples:

Interviewer: Another idea I've noticed is that many students name mostly White men as being important in history. Do you agree that most of the important people in United States history are White men?

Salvador: $\quad$ A lot of them are, but then some are Black, like Martin Luther King. There was like Harriet Tubman, there was Frederick Douglass. (interview, 12/14/15) 
While Salvador's response featured three African American figures found in the official curriculum, he clearly framed his argument as a counter-point to the assertion that U.S. history included only "White men" by naming three "Black" individuals. Javier demonstrated similar reasoning when he identified Abraham Lincoln as "one of the Black people that helped with the...focus that Black people are not... animals" (interview, 12/16/15). In response to the preliminary finding that "White men" dominated students' perspectives, Javier said he would like to learn more about Martin Luther King. In this retelling of history, Javier appeared to identify Whites as the norm, identifying anyone outside of this racialized mainstream as "Black." Yousuf explicitly named this binary perspective when, in response to a question about whether Mr. Mitchell's class focused on "White men," he responded: "I don't know, but it's like Black and White...I don't know how much" (interview, 12/9/15).

Students interpreted the overall dearth of Latinos and other ethnic groups within the official curriculum in different ways. For example, Javier used the lack of Latinos to explain why most students identified primarily "White men": "I've mostly never heard of a Hispanic guy in history in all my years" (interview, 12/16/15). Felix demonstrated a similar understanding and resulting assumption when he said he would like to learn "more about Frederick Douglass" as a way of learning about historical figures other than Whites. Felix added that while he would be interested in learning about Latino Americans, their exclusion from the curriculum led him to the following conclusion: "I don't think they really did much" (interview, 12/15/15). Both Javier and Felix named "never hearing of a Hispanic guy" as a reason they had limited historical knowledge of the contributions of Latinos in U.S. history. 
Even when Maria did identify a Latino as an important historical figure, the prevalence of the Black and White narrative persisted. In their December interviews, both Maria (interview, 12/14/15) and Salvador (interview, 12/14/15) named César Chávez as an example of a person of color with historical significance. Yet, even as Maria provided a sophisticated explanation of why mostly "White men" dominated the U.S. history narrative, she employed the same Black and White narrative as her peers:

Maria: $\quad$ Yes. Yes, I think most of the men that did good things were White, because when we came here to the U.S.A., there was slavery. No one in slavery could do anything right because we didn't do anything great. We got on a very rough start into getting what we knew and having all these people do the wonderful things they do. George Washington was the first president and he was White. Thomas Edison made electricity. He was White. Rockefeller was White. All those people we're learning about are White, except for the person we're learning about today who is not White and the lady we were learning about last time who was not White, but those are the only two people we did learn about that weren't White.

Interviewer: Do you know the names of the people, examples you were just giving? Today, you just said for example.

Maria: Robinson, Jackie Robinson. That one guy in baseball. (interview, 12/14/15)

Maria first identified the institution of slavery — a central component of the discrimination narrative - as a primary rationale for why people of color "didn't do anything great." She then provided examples of White men to whom she attributed historical significance. Maria concluded that there were "only two people we did learn about that weren't White" and named Jackie Robinson. While Maria's identification of Jackie Robinson - the first African American "guy in baseball"-may appear to reflect a focus on slavery, Maria had previously identified "the day slavery ended" as important "because I would have been a slave, but I still like my skin color so I really don't care" (interview, 12/14/15). As such, Maria's conceptualization of slavery and nomination of 
Robinson both appear to reflect a focus on "non-White" historical figures rather than specifically African Americans characters. Such an approach reflected the same binary framing that Yousuf and others had employed. In the following section, I examine how students' national origin interacted with their historical perspectives.

\section{National Origin}

While the participants identified nuanced connections between their national origins and notions of place and identity, their historical perspectives rarely reflected these concepts. Rather, students' historical perspectives often reflected the same "Black and White" binary that marked students' dialogue around race and ethnicity. However, students did connect their own individual or family experience with immigration to their historical perspectives. In this section, I first examine how the participants conceptualized national origin around the notions of place and identity. I next describe their analysis of contemporary perspectives on immigration. I then analyze the participants' perspectives on historical immigration.

"He's born here so he's from here": Conceptualizing national origin. While Santiago and Yousuf were the only participants who selected the "immigrant" card during their December interviews, all of the participants demonstrated a sense of being connected to other countries. For example, nine of the participants selected descriptors for specific countries of origin. Santiago, Felix and Isabel chose the "Mexican" card. Maria, Yonas, and Javier selected the "Honduran" card. Gebre and Yonas each chose both the "Eritrean" and "Ethiopian" descriptors. Marisol identified the "Salvadoran" card. 
Of the four students who selected the "American" card, Felix, Isabel, and Maria were born in the United States. Felix explained that he chose the "Mexican" card "because my parents are from Mexico" and then added, "I'm American" (interview, 12/15/15). Isabel described herself as "originally from here" before explaining: "I'm Mexican because that's where my origin is from. I'm American because I've lived here and I've gotten used to being here" (interview, 12/10/15). Maria described her selection of nationality descriptors in similar fashion: "I chose Honduran because most of my heritage is Honduran...I chose American because I'm American, I'm from America" (interview, 12/14/15). The fourth student—Yousuf—explained that he "called" himself an American because "I came like immigrant" (interview, 12/9/15). Aras and Salvador were the only two students who did not choose a card denoting national origin during the December interviews. Each had previously selected the "American" card and reported being "born here" (Aras, interview, 9/10/15) or being "from Virginia" (Salvador, interview, 9/16/15) during their September interviews.

In addition to the card selection activity, students in Mr. Mitchell's class frequently drew on concepts of place and language when discussing notions of identity during observations. For example, on the second day of school Marisol and a fellow Latina emergent bilingual asked another student about his background:

Marisol and BG are asking Antonio about being from El Salvador and speaking Spanish: Antonio says, "I'm from El Salvador, but I was born here." Marisol and BG appear to be interrogating him: "Why don't you speak Spanish?" Antonio is in retreat mode: "A little...I don't know." [AN: This is an interesting identity/language connection.] (fieldnotes, 8/26/15)

In this brief exchange, Marisol asked Antonio to explain where he was from and then expressed confusion when he described being "from El Salvador," but not speaking 
Spanish. As "una immigrante/an immigrant" who had moved from El Salvador during the previous school year, Marisol clearly associated being "Salvadoran" with speaking Spanish. When I asked Marisol about this exchange during her December interview, she explained that she expected Antonio to know Spanish because "he is from El Salvador" (interview, 12/18/15). Marisol further elaborated on what it meant to her to be "from" another country:

Marisol: $\quad$ Porque si él nació aquí, y puede ser que sus padres, su mamá o su papá pueden ser de allá, pero como él nació aquí, entonces él es de aquí.

Interpreter: He was born here so maybe his mom or his dad could say they are from there, but he's born here so he's from here. (interview, 12/18/15)

In her explanation, Marisol made the distinction between having roots in another country and being "from" that country. She appeared to reject Antonio's assertion that though he was "born" in the United States, he could still be "from El Salvador." Rather, Marisol concluded that while Antonio's parents could say they were "from El Salvador," Antonio was “de aquí/from here." As such, Marisol appeared to draw on both her own lived experience of migration and her linguistic knowledge of Spanish in crafting her own Salvadoran identity.

Yousuf similarly linked the immigrant experience to language. However, when Yousuf addressed the topic of linguistic knowledge during his December interview, he focused on the need to learn a new language rather than the sense of identity derived from knowing a language other than English. Yousuf described how being an immigrant was "really hard" because "you've got to learn language that you don't know how to speak" (interview, 12/9/15). When I asked what else was hard, Yousuf stated: "The life-like the life is different because when I came over here; I can't sleep because it was different, 
the time was different." Yousuf added that learning about immigrants in school was important "because when you go to the United States you're going to be one of them. I'm one of them" (interview, 12/9/15). Yousuf's perspectives on the immigrant experience reflected his own adjustments in the year prior to the study. For Yousuf, the need to "learn language" represented a visible part of how "life is different" for immigrants in a new place.

Javier also referenced multiple dimensions when discussing his own national origin. During both his September interview (9/14/15) and the Jackson Heights focus group (11/19/15), Javier described being born in Jamaica Hospital in New York City. He also employed this information during a classroom interaction:

In a lesson on the impact of the 14th Amendment, Mr. Mitchell is explaining how people can either be "born citizens or take a test- the official test." Javier turns in his seat and says, "I'm a citizen." Maria asks, "Are you naturalized?" (fieldnotes, 9/11/15)

In this field notes excerpt, Mr. Mitchell described the 14th Amendment as granting citizenship. Javier then turned to Maria and stated that he had citizenship. Maria's response reflected her apparent assumption that Javier had been born outside of the United States and would have needed to be "naturalized" in order to be a U.S. citizen. Though Javier did not respond to Maria's question during that class, his later storytelling about being born in New York clarified that he was a natural-born citizen. The fact that Javier chose to announce that he was a citizen during class suggests that he may have associated having citizenship with a certain social status. Yet subsequent classroom interactions demonstrated that Javier also prized other aspects of social identity. For example, when watching a video in which an astronaut introduced himself as an immigrant, Javier called out: “That's me!” (fieldnotes, 10/5/15). During Mr. Mitchell's 
class the next day, Javier identified himself as "Catracho"- - a term used to refer to people from Honduras:

Javier is up out of his seat again. Marisol asks Javier in Spanish if he is Mexican. Javier and Miguel both say that Javier is "Catracho." Marisol persists, asking if Javier's dad is "Dominicana." (She continues to speak in Spanish.) Javier replies, "I don't know-they separated." (In my first interview with Javier he had also noted that his mom and dad separated when he was very young.) Marisol is talking with Miguel again. BA asks Javier, "Where are you from?" Javier replies, "I'm Catracho, but I don't know where my dad's from." [AN: IdentityWhy did this come up again?] (fieldnotes, 10/6/15)

In this classroom exchange, Marisol questioned Javier about his identity, specifically if he or his family were Mexican or "Dominicana." Javier described himself as "Catracho" on multiple occasions, including when BA directly asked, "Where are you from?” By repeating that he was "Catracho"_ _rather than being "from" Honduras_-Javier appeared to make a subtle, yet important distinction regarding his social identity. As Javier had previously noted, he was born in New York and was thus a U.S. citizen. However, rather than identifying as "American" as his U.S.-born peers did, Javier reported to his classmates that he was a "Catracho" even though he was not born in or "from" Honduras himself.

Other participants who had also been born in the United States, but who like Javier had direct family ties to another country, described learning about their "heritage" from family members. For example, Maria reported asking her mother about the traditions and history of Honduras, such as how people celebrate Child Day and who the first president was (interview, 12/14/15). During her December interview, I asked Maria to elaborate on what she meant by the term "heritage":

Interviewer: I know we talked about this a little bit a couple months ago when we sat down together, but I'd like to ask you about Honduran and 
American. I think you used the word heritage for Honduran. What does it mean that your heritage is Honduran?

Maria: I mean I celebrate American stuff like the Independence and everything, but I say heritage for Hondurans because my mom is Honduran and I don't have an American father or mother. I don't really follow their heritage, but I follow the Honduran heritage because my mom is Honduran and because she knows a lot about their history. I ask her things and follow most of the heritage. I'm just in America and I'm just American.

Interviewer: I know this feels like I'm asking the same question again, but let me maybe ask for a definition of the word heritage. What does the word heritage mean?

Maria: When you follow their religion, celebrate their country's things, like if a very important person died in Honduras, then we wouldn't celebrate it, but we would have a day for it and we would honor day or something. Yeah, that's it.

Interviewer: Then maybe let me think of that same idea for the word American. Could you define the word American?

Maria: A person who was born in America, and I celebrate things in America. I don't really get to go to Honduras that often. I go in the middle of summer and that's only 2 months. (interview, 12/14/15)

Maria identified learning about history and honoring traditions as important aspects of "heritage." She explained that she "followed the Honduran heritage" because her mom was from Honduras. By contrast, Maria self-identified as an "American" even though she did not "have an American father or mother" because she was "born in America." Aras and Felix were also "born in America" as the children of immigrants. When I asked Aras if his parents taught him about the history of Kurdistan or Iraq, Aras reported that "they were at war a long time ago when they were kids, and the war that's happening right now" (interview, 9/10/15). Felix similarly noted that he had learned about "some history of Mexico" at home (interview, 9/17/15). For these students, the history of their parents' homeland provided a link to the "heritage" of their families and each one's respective nation of origin. In short, while the participants interpreted being "from" somewhere as an indication of having lived in that place and consequently experienced 
life as an immigrant, the students also drew on their linguistic and historical backgrounds to shape their identities as individuals who may be "American" but who also claimed other national origins. In the next section, I examine how these understandings influenced students' analysis of contemporary perspectives on immigration.

\section{“People don't want Syrian refugees": Contemporary perspectives on}

immigration. When discussing contemporary perspectives on immigration, the participants frequently referenced both current events and their own experiences in order to determine how or whether to employ the discrimination narrative. For example, during his December interview Gebre drew on both his own experiences as a refugee and recent news events as he lamented the mistreatment of refugees. Gebre first identified President Obama as an important person based on Obama's willingness to accept refugees. He then explained that the recent terrorist attacks in Paris were important “because that shows that people don't want Syrian refugees because they think they're all terrorists, but they're not all terrorists" (interview, 12/18/15). In response to a question asking him to compare the past and the present, Gebre provided a nuanced response:

Interviewer: Do you think Americans would have been nice to you and your family if you lived in the past?

Gebre: I thought actually that they weren't as nice in the past because now, they let Mexicans, all of them in but now, the Syrians and all of that stuff. I know that's bad but not as bad as before because they didn't want them. They were willing to do stuff that shouldn't have been done to get them out of the state and to get them out of the country. They do stuff like this [gestures to political cartoons] but now today, they are nicer. You see Mexicans all around doing their normal stuff and Africans, all that stuff, all the races doing what they're doing right now. Before, they weren't able to do those things. They weren't able to get in to the country. They weren't able to do anything mostly.

Interviewer: When you're saying "they" who are you talking about?

Gebre: I am talking about the people who didn't like different races other than their own... They didn't want Mexicans and all those things 
because they thought they were bad and all those things. They thought they didn't need them - they didn't need their help or anything. (interview, 12/8/15)

While asserting that Americans "weren't as nice in the past," Gebre described how "Mexicans," "Africans" and "all the races" were currently treated better than at other times in history. The notable exception to Gebre's assessment was the contemporary rejection of Syrian refugees. However, Gebre concluded that the treatment of Syrians and other groups was "not as bad as before" given that U.S. history provided examples of people "who didn't like different races other than their own." In sum, while Gebre employed the discrimination narrative when he described the labeling of Syrian refugees as "terrorists," Gebre also used the equality narrative when he explained that people were "nicer" than in the past. Gebre's analysis seemed particularly nuanced given his own status as a refugee. Notably, Gebre maintained his focus on equality even when treatment of Syrian refugees did not support his overall assertion.

While few of Gebre's fellow participants mentioned refugees, many did employ the discrimination narrative as they voiced their perspectives on contemporary immigration. For example, during a lesson on immigration, Maria connected Mr. Mitchell's historical analysis to her own evaluation of the present-day treatment of immigrants:

Mr. Mitchell asks about Jane Addams and what students remember from the previous day. After Javier says he was taking a "nap nap" and didn't remember, Mr. Mitchell states that immigrants had problems and were "not treated well." Maria chimes in, “That's still true." (fieldnotes, 10/29/15)

Maria's assessment that the problems immigrants had faced in the past were "still true" reflected the same understandings students in both schools voiced in response to the 
political cartoon sorting activity during the focus group interviews. For example, Gebre described the negative effects of generalizations about African immigrants:

I think, kind of both because people have been racist to me before and I've heard on the news how Africans are being treated, like from being like some people say like, "All Africans have Ebola and stuff"- just because it started in Nigeria. And I just felt bad for...for being, like, for those people who are saying that. Like why would they want to say that? Why would they want to make fun of people even though it's not their fault?

(focus group, 11/24/15)

Gebre specifically named the backlash against the recent outbreak of Ebola on the African continent as having sparked anti-African rhetoric in which some people "make fun" of Africans "even though it's not their fault." During the same focus group interview, Santiago and others also discussed how Donald Trump was "being really racist to Hispanics, especially Mexicans" (focus group, 11/24/15). During the Jackson Heights focus group, Maria and Javier expressed similar disapproval of Trump's rhetoric:

Maria: Well, I'd like to add that—for example...I have my dislikes, but I don't say it out loud because I know people will... and I don't want to have all these enemies, I mean, I'd rather have friends I can go crazy around. Some people get me.

Javier: (Javier is sighing heavily into the microphone)

Interviewer: Sure

Maria: $\quad$ Other times, like for example, let me use DONALD TRUMP!

Javier: Yeah, I hate him!

Interviewer: Okay

Maria: I don't hate him, but I think what he is doing is like... is just bull poop!

Yonas: Bull poop!

Javier: (chuckles)

Maria: Because he's saying that immigrants are this and immigrants are that, but guess what? This land isn't immigrants'. You want to know whose land it is?

Yonas: Who?

Maria: It's - he actually is an immigrant because this is not his land - this is the Indians' land. What he drinks - for example - tequila, is not his. It might be from outside Europe or somewhere else. What he sleeps in is not made or manufactured there, maybe it was manufactured in China. Like for real, this dude is like stupid. 
Javier: And racist!

Maria: $\quad$ And this dude got to stop - this dude is gonna hit by the choncola if he doesn't stop — by El Chapo, I mean, I'm serious.

Javier: $\quad$ By El Chapo, yeah

Maria: $\quad$ Yeah, El Chapo is going to kill him!

Interviewer: Can you tell me what...you said El Chapo?

Javier: $\quad$ There's going to be World War III, mister.

Maria: $\quad$ El Chapo is...

Javier: $\quad$ The Mexican guy that has...

Maria: $\quad$ El Chapo is this nacrotraficancte.

Javier: $\quad$ That smoke some weed! (focus group, 11/19/15)

During this extended exchange, Maria and Javier both described frustration with Trump's anti-immigrant statements, concluding that such rhetoric would have major ramifications including significant violence. A few weeks later, during his December interview, Santiago also voiced frustration with Trump's "racist" views against immigrants. Santiago explained that while no one had "gone up to me or up to my family and said something racist about us," he had seen Trump "on the news" and viewed Trump's plans "to deport all of the immigrants who are people from different countries" as "racist." In his reporting of Trump's statements about immigrants, Santiago clearly reflected on current events, while simultaneously incorporating his own social identity as an immigrant to explain contemporary perspectives on immigration. In the next section, I examine the interaction between students' national origin and their perspectives on historical immigration.

“They didn't just appear": Perspectives on historical immigration. The participants' perspectives on immigration in U.S. history reflected the same complex relationship between the nation-building narrative and the discrimination narrative that Isabel had described when discussing the westward migration of European Americans. For example, during a class discussion Maria asserted that "No one is here that's 
supposed to be except for the Indians that died" (fieldnotes, 11/4/15). During the Jackson Heights focus group, Maria elaborated while interpreting a political cartoon depicting the Statue of Liberty laying horizontal on the U.S.-Mexico border (see Figure 12):

It looks like they're trying to stop other immigrants from coming in from the border, but those were the - that was the one bridge that brought George Washington and Abe Lincoln because they weren't born-God didn't put them there...Abe Lincoln's ancestors or parents crossed the borders to get to America. They didn't just appear all of a sudden. (focus group, 11/19/15)

Maria stated that only the Native Americans were "supposed" to live in the land that now constituted the United States. As such, Maria contended that immigration served as a longstanding "bridge" that even George Washington and Abe Lincoln had crossed, concluding that "Lincoln's ancestors...didn't just appear all of a sudden."

However, when Isabel analyzed the same political cartoon during her December interview, she referenced the discrimination narrative in order to contextualize the images and drew a very different conclusion. Isabel first articulated aloud what she saw: "I see Mexico, the border, and the Statue of Liberty on her side. It was blocking their path" (interview, 12/10/15). Isabel then employed the discrimination narrative when she compared the cartoon to the history Mr. Mitchell had presented in class, including how “Asian and Chinese were winning and they started putting acts and laws so it'd be hard for them... One act stopped them from coming in anymore." Rather than following Maria's example of referencing the "Founding Fathers" and the nation-building narrative as a critique to the anti-immigrant message of the cartoon, Isabel described how the image of the State of Liberty "blocking" potential immigrants at the border reflected notions of racism within the discrimination narrative. At different points Isabel and Maria's fellow participants similarly employed either the nation-building narrative or the 
discrimination narrative in ways that reflected their understandings of historical immigration.

When students connoted that some people did not belong in the United States, their statements routinely reflected elements of the discrimination narrative. For example, while describing what he had learned in Ms. Rogers' class, Felix reported learning about "freedmen" during Reconstruction. When I asked Felix to define the term "freedman," he stated that freedmen were "pretty much every person that's not from America and they get their...they're free. They're not slaves anymore" (interview, 12/15/15). While Felix's final statement reflected the common understanding of "freedmen," his assertion that freedmen were "not from America" provided an important insight into Felix's racialized perspectives on immigration and the notion of belonging. Yousuf made this association more explicit while similarly describing Reconstruction. Yousuf first described how "Black people" were "hung" or lynched following the Civil War. In response to a question about who lynched African Americans, Yousuf replied, "The White people, the Americans, they hung the African Americans. They treat them as animals" (interview, 12/9/15). In his statement, Yousuf provided clarity on what it meant to be "American" or conversely "not from America." For Yousuf, "the White people" were "the Americans." Therefore, those freedmen who were lynched-"Black people" or "African Americans"- - were not true Americans, much as Felix had denoted when he said "freedmen" were "not from America." While discussing the immigration political cartoons during the focus group with Mr. Mitchell's students, Yonas demonstrated a similar conceptual framework: "I don't like the American, like they was coming to America and the American guys - he's so-I don't like that" (focus group, 11/19/15). 
Yonas noted that because those "coming to America" were turned away in the cartoon, he did not "like the American" who had rejected the immigrants. While Yonas did not explicitly address race in his analysis, the role of "the American" as the one who discriminated against those from another social group reflected the ways in which Felix and Yousuf had also employed the discrimination narrative. In these examples, the participants employed the discrimination narrative when they characterized the ways in which "Americans" or "White people" had mistreated African Americans as reflecting an understanding of non-Whites as "being from" someone else and not belonging.

Conversely, some participants employed the nation-building narrative when describing their perspectives on historical immigration. For example, when describing the role of race in determining historical significance, Santiago first acknowledged discrimination before employing the concepts of strength and unity from the nationbuilding narrative:

Interviewer: Another idea I noticed is that many students name mostly White men as being important in history. Do you agree that most of the important people in the United States history are white men?

Santiago: Most of them are. Because back then, they chose only White people because they would discriminate against other races. Now it's kind of changing. There's more and more different people from different countries, places that are starting to do the same things.

Interviewer: I understand that when you're saying there are people from different countries, different places, and then you said they're starting to do the same things. What do you mean by the same things?

Santiago: I guess helping the United States become better.

Interviewer: What does it mean that to become better?

Santiago: Become, I guess, stronger and more united, everyone coming closer and having less hate for each other. (interview, 12/16/15)

In this interview exchange, Santiago first asserted that "White people" used to "discriminate against other races." However, his comment that "people from different 
countries" were "helping the United States become better" reflected the nation-building narrative and a focus on making the U.S. "stronger and more united." The ways in which some of Santiago's fellow participants used first-person plural pronouns also revealed their use of the nation-building narrative. For example, Isabel explained that "The Mexican and Texas War" was important because "Our nation got bigger" (interview, 9/10/15). Felix similarly identified the Revolutionary War as being important as it provided "our freedom from England" (interview, 9/17/15). Salvador also used the term "we" on multiple occasions while discussing historical treatment of Native Americans during his December interview:

Salvador: About American Indians, and how we forced them to...We took their land, and like child labor laws, and then how it was before laws were passed. We learned about ghettoes, tenements, and immigration, like all of...Right now, we're talking about tolerance and how some people are tolerant to other people, and then...

Interviewer: What does it mean to be tolerant?

Salvador: You don't have to like them, but you have to show them a decent amount of respect.

Interviewer: If you think about this idea of being tolerant, and some of the examples you gave, have you talked about, or what's your opinion about whether people have tolerated the American Indians?

Salvador: Some people did, some people didn't. Most likely, the British didn't because they kind of forced them off their land. They didn't like them. They didn't respect them.

Interviewer: When you first mentioned the American Indians, you said "We forced them off their land, and we took their land." In that case, is "we" the British? Are you talking about like you and me, or the people in Ms. Rogers's class? Who's the "we" in that situation?

Salvador: I kind of meant like the whole British, the British who came over to America. (interview, 12/14/15)

During this extended interview exchange, Salvador used the pronoun "we" to describe those who removed Native Americans from their land. He explained that "the British didn't [tolerate the Native Americans] because they kind of forced them off their land." In his initial word choice, Salvador had identified with the "some people" - namely "the 
British who came over to America"-who had discriminated against Native Americans. In so doing, Salvador employed the nation-building notions of progress and expanding the country much as Isabel and Felix had. While these examples do not all address immigration directly, they demonstrate that just as some participants employed the discrimination narrative to demonstrate how they did not identify with "the Americans" in U.S. history, at times other participants described historical perspectives that reflected a sense of belonging and the nation-building narrative. In the following section, I examine the interaction between gender and the participants' historical perspectives.

\section{Gender}

While nine of the eleven participants selected either the "boy" or "girl" selfidentification card during their December interviews, only Maria and Isabel explicitly discussed gender within their historical perspectives, focusing primarily on examples of discrimination against women and historical efforts to achieve women's rights. Overall, there was very little discourse around gender either within the classroom instruction or student discourse. One exception to this was Ms. Roger and Ms. Andrews' explicit identification of the limited involvement of girls in Ms. Rogers' class at the beginning of the school year (analytic memo, 9/5/15). After Ms. Andrews had completed her push-in unit on Reconstruction, Ms. Rogers' continued to specifically engage female students over the following weeks. For example, Ms. Rogers would occasionally ask, "Do I have a girl that's willing to say something?" (fieldnotes, 9/16/15).

The primary example of how Maria's gender identity interacted with her historical perspectives stemmed from a classroom observation in which students were 
watching a video. During the unit on Reconstruction, Mr. Mitchell showed a video clip in which actors portrayed a slave auction:

1:12 The "History of US" video shows an actor portrayal of a slave auction. One of the potential buyers appears to be inspecting a female slave. "He touched her boobs!" Maria yells and then laughs....At the end of the class period, Maria asks Mr. Mitchell why the man "touched her boobs." Mr. Mitchell replies, "They checked the health like you are an animal," noting that slaveholders wanted to know if female slaves could have babies much "like a puppy mill—more babies equals more money." (fieldnotes, 9/9/15)

During the video, Maria responded forcefully to the depiction of a White man touching a female African American slave. At the end of class, Maria asked Mr. Mitchell about the incident and he responded that slaves were treated like "animals." Having noted Maria's critical engagement during these interactions, I asked Maria about this series of events during her December interview:

Interviewer: In this example, you asked about the treatment of female slaves. There was a video in which it showed a slave auction. In the video, a White male or a White man grabbed a Black female slave, and you called out, "He grabbed her boob!" At the end of the period, you asked Mr. Mitchell about what happened. He said that the potential buyer was wanting to know if the woman could still have babies, like comparing having a slave to having puppies. I wanted to first ask, what do you remember about this video in this class?

Maria: $\quad$ That after that, we talked a lot about it.

Interviewer: That you talked about it?

Maria: $\quad$ Not me, but these people. My friends, they were like, "Oh, this guy touched her boobs. He is like so sexist....This guy's perverted.” I don't know...some very inappropriate things, too, because my friends are like that. My friends are very perverted. They are very...just kidding.

Interviewer: You used the term inappropriate. Are you saying the comments were inappropriate or what was on the video was inappropriate?

Maria: $\quad$ No, I'm talking about my friends' comments. I call them my friends, but not my friends like, "Oh, you're my friend. Oh!” No, I'm talking about Javier and BA. They're very inappropriate, especially BA.

Interviewer: As I mentioned here, Mr. Mitchell was explaining that when someone was looking to buy a slave, it was like nowadays 
someone buying an animal, like a puppy. What did you think or feel about how he responded to the question?

Maria: I forgot what he said about the question really. I don't know. I reacted weirdly because I didn't think that males were that bad. I didn't think it was that bad in slavery that they would actually touch them like that, and they would have no say about it. If you thought about it, if you did that to a puppy, the puppy would go off on you. They'd be like, "Why you touching my boobs? That is not right. You are crazy." The women didn't actually do that. They just stood still because they knew the expectations, which I thought was pretty stupid because you're not just going to stand there while a man touches your boobs. That's just stupid. (interview, 12/14/15)

In this extended interview exchange, Maria related her own thoughts and those she attributed to her peers when she described the male character in the video as "sexist" and "perverted." She added that Javier and other male students made "inappropriate" comments in response to the video. Maria then concluded that she previously "didn't think it was that bad in slavery" and though she recognized that female slaves could not fight back against sexual assault because "they knew the expectations," Maria concluded: “That's just stupid." Maria's original response during class and her further analysis during the December interview suggest that she identified with the female historical character. Though Maria asked Mr. Mitchell to explain the video, Maria subsequently focused on the reactions of male peers before providing a complex description of how this example of sexual discrimination informed her historical perspectives on how "bad" or "stupid" slavery was.

Whereas the example above highlights Maria's nuanced use of the discrimination narrative, Isabel employed the equality narrative when she described the role of women in her historical perspectives. In addition to selecting the "girl" card during her December interview, Isabel also selected the "feminist" card- "because I believe women 
should have equal rights" (interview, 12/10/15). Later in her interview, Isabel provided examples of the struggle for rights - particularly women's rights - in U.S. history:

Interviewer: What have you learned about so far this year in Mr. Mitchell's class?

Isabel: $\quad$ Slavery, African American rights, women's rights, and equal rights.

Interviewer: What would be an example of women's rights that you learned about?

Isabel: Women's rights. What women did for their rights. They didn't eat for one of them, they didn't eat. For another one they would do parades and marches.

Interviewer: What were they trying to achieve, or what were they fighting for? Isabel: One was for the right to vote and another one was for equal rights, like to stand in court, to be able to speak in court and educational rights. (interview, 12/10/15)

In response to an open-ended question about Mr. Mitchell's class, Isabel focused on women's rights as a key concept, one that clearly interacted with her own identity as a self-described feminist. In addition to naming the concept of "women's rights" as important, Isabel also named particular strategies and goals of the women's rights movement. Later in the interview, Isabel described also learning about "girls or women" in "movies" or "books." She related the importance of historical activism for women's rights to her assessment of historical significance based on "the general idea about — this certain person did something that now helps us today" (interview, 12/10/15). Isabel's assessment reflected her employment of the equality narrative in both her historical perspectives and as part of her own social identity as a self-described feminist.

Other than Isabel and Maria, few students explicitly addressed gender as part of their historical perspectives. For example, when I presented students with the assertion that students "name mostly white men as being important in history," only Salvador included a woman as a counter-example in his response: "A lot of them are, but then 
some are Black, like Martin Luther King. There was like Harriet Tubman, there was Frederick Douglass" (interview, 12/14/15). Even in this example, Salvador's response focused on an understanding that among significant historical figures "some are Black." As such, Salvador most likely chose to include Harriet Tubman because she was an African American. Similarly, when Yousuf explicitly included women while discussing the importance of overcoming discrimination, he also focused on race:

The third [important event], about the racism, they didn't want no racism and stuff, they want everything equal...The Black people wasn't like the White people or the Chinese or Hispanics so they want others to see the same because they're just people, the womans $[s i c]$ the same as the mens here. I think Elizabeth was her name, the one that was for the womans to work, yeah. (interview, 12/9/15)

In this interview excerpt, Yousuf first identified "racism" and the desire to make "everything equal" as predicated on the treatment of "Black people" and then "the Chinese or Hispanics." Yousuf then employed the equality narrative when he added that "the womans the same as the mens here" and attributed Elizabeth Cady Stanton with fighting "for the womans to work." While neither Yousuf or Salvador referenced their own gender identities when they attributed Elizabeth Cady Stanton or Harriet Tubman with historical significance, their interview responses served as the only additional examples of women being described as part of the participants' historical perspectives. As in the instances including Isabel and Maria, Yousuf and Salvador also employed notions of discrimination and rights when discussing female historical figures. In the next section I examine how students' religious identity similarly mediated the participants' historical perspectives. 


\section{Religion}

While few students explicitly identified themselves as religious or discussed religion more broadly, when students did address the role of religion in their historical perspectives they employed the discrimination and equality narratives to compare the past and the present. The two students who self-identified as Muslim, Aras and Yousuf, were the only two who selected an identity card related to religion in both their September and December interviews. Aras and Yousuf's individual choices to select the "Muslim" card in both interviews suggests that being Muslim was a consistent or fundamental part of each student's social identity. Among the other participants, three students selected the "Christian" card in one of the two interviews. Gebre referenced the role of family connection in his religious identity: "I'm a Christian because my mom told me she loves God and all of those things and I do, too" (interview, 9/9/15). While Isabel also expressed a social component to religious identity, she demonstrated some uncertainty after selecting the "Christian" card: "I'm a Christian because...I think I'm a Christian. I forgot which one we were" (interview, 12/10/15). Javier also identified himself as a Christian (interview, 9/14/15).

Among the participants, only Aras, Gebre, and Yousuf explicitly addressed religion as part of their historical perspectives. Each named the treatment of people who shared their own religious identity when describing religious freedom and religious persecution as examples of the equality and discrimination narratives. For example, Gebre described religious freedom as an important aspect of allowing people to practice their culture, providing a counter-example from U.S. history:

Like in England, you couldn't do stuff like that. You have to go by the rules which King James I think went by. You have to go to church and all of those 
things but you couldn't go by your own religion.... [Once people came to the United States they were able to do] different things like they were able to go by their religion and not have to be mean to do all the things that they don't want to do. (interview, 12/8/15)

In his interview response, Gebre identified religion as a fundamental component of culture and then employed the equality narrative when he presented an historical example of how the U.S. provided religious freedom.

By contrast, Aras and Yousuf employed the discrimination narrative when they compared their own experiences as Muslim Americans to the historical mistreatment of other groups. During his December interview, less than a week after Donald Trump had called for the "total and complete shutdown of Muslims entering the United States" (Justice \& Stanley, 2016, p. 38), Aras identified "racist people" as a major factor in how he assessed both the past and the present:

Interviewer: Do you think people would have been nice to you and your family if you lived in the United States in the past?

Aras: $\quad$ I'm not really sure, but I mean, there's still a lot of racist people that's in now.

Interviewer: Okay. There's some of the same problems in history and currently? Aras: $\quad$ Yeah. (interview, 12/9/15)

When I asked Aras to explain, he contrasted the depictions of Muslims as terrorists with his own understanding of his religion:

I mean, [the recent news about some people saying Muslims should not come into the United States] is messed up, because in every single religion or type of culture there is a couple of bad people, but not all the people are bad...I mean, anyone can be American. But Muslim, it's because, people don't know that the terrorists, they're not Muslim because Muslim means peace. (interview, 12/9/15)

Within this extended interview exchange, Aras clearly drew on aspects of his own identity, stating that "anyone can be American," but rejecting the use of violence "because Muslim means peace." Aras provided a historical context for the anti-Muslim 
rhetoric, identifying the "messed up" characterization of Muslims as evidence that "there's still a lot of racist people."

Yousuf expressed a similar perspective during his December interview later that same day. At the close of the interview, I asked Yousuf how he felt about the recent antiMuslim rhetoric. Yousuf at first distanced himself from the conflict, before asserting that “terrorists" did not represent all Muslims:

They know I'm Muslim, but nobody talked to me, but I saw some videos. I think Muslim, they think is terrorist, but it's not terrorist, because in every religion, there's bad kind of people, and good kind, so it's even like in Jewish or Christian, there's bad kind and good kind. There's no difference. People that do that bad stuff, they're another part of Muslims. They're not the good kind. They're the bad kind. (interview, 12/9/15)

As Aras had stated a few hours before at the school across town, Yousuf asserted that "every religion" had "people that do that bad stuff." He identified terrorists as "the bad kind" of Muslims, emphasizing that "Jewish or Christian" communities also had "bad kind and good kind." When I asked Yousuf to compare the treatment of Muslims to the historical treatment of immigrants, he paralleled the treatment of Muslims to the discrimination of African Americans and Chinese:

Interviewer: When we talked about some things you learned in Mr. Mitchell's class about maybe immigrants in the past, do you see that it's similar now, or do you feel like it's different?

Yousuf: It's like the same. It's like how in the past African American was treated bad, now Muslims - they're trying to kick them out. It was like the Chinese, trying to keep them off.

Interviewer: Help me understand, when you say, "Kick them off...?"

Yousuf: $\quad$ In the paper, they say, "Chinese Must Go.” It's like just the same. (interview, 12/9/15)

In this interview exchange, Yousuf employed the discrimination narrative to both his historical perspectives and his views on current events. Both Aras and Yousuf described being Muslim in terms of racial or ethnic identity as denoted by their use of the terms 
"racist," "African American," and "Chinese." Each of these Muslim students drew upon his historical perspectives and employed the discrimination narrative to explain contemporary anti-Muslim rhetoric. By contrast, Gebre employed the equality narrative when describing the importance of religious freedom among English colonists. In short, among the few students who explicitly addressed religion, the discrimination and equality narratives served as important mediating devices to bridge students' historical perspectives and their experiences and identities. In the following section, I examine three participate cases to explore how the interaction between various aspects of individual students' identity contributed to their historical perspectives.

\section{Participant Cases}

Given the interconnectedness of the various aspects of students' identity, I conclude the examination of the interaction between student characteristics and their historical perspectives with three participant cases. I have selected these cases in order to address various themes and include multiple student characteristics found among the eleven participants. First, I present the case of Felix, a Latino emergent bilingual from Ms. Rogers' class. Next, I examine the case of Maria, a Latino bilingual student from Mr. Mitchell's class. Finally, I explore the case of Yonas, an Eritrean emergent bilingual from Mr. Mitchell's class.

"I'm half Mexican": The case of Felix. Felix described himself in terms that reflected a multifaceted identity. For example, Felix reported being born and raised in Virginia. Yet Felix concluded that he was "half Mexican" because his parents were both Mexican immigrants and half American "because I was born here" (interview, 9/17/15). Felix was labeled as an emergent bilingual with an intermediate English proficiency level 
as denoted by a level 4 WIDA score. While he stated that he spoke Spanish at home, Felix also identified as bilingual and an English-speaker during his December interview. Felix selected the student, friend, and brother self-descriptor cards. He also identified as an athlete and an actor (interview, 12/15/15). Though he had attended Virginia schools throughout his academic career, he fell short of a passing score on the sixth grade reading SOL by a few questions.

Felix demonstrated a nuanced understanding of and relationship with U.S. history. On one hand, he frequently employed the nation-building narrative when identifying events and actors in U.S. history. For example, Felix described the Revolutionary War (interview, 9/17/15), Thomas Jefferson's Declaration of Independence (interview, 12/15/15), and the growth of factories (focus group, 11/24/15) as important because they each contributed to the formation and growth of the United States. Felix also reported that history was his favorite subject in school (interview, 9/17/15). However, when Felix attempted to connect his Mexican, Hispanic, and immigrant background to what he was learning about U.S. history, he drew upon the discrimination narrative either implicitly or explicitly.

In short, Felix described his historical perspectives and his own positionality in ways that suggested he experienced dissonance between U.S. history and his own identity. For example, Felix reported learning little about Hispanics or Latina/os in U.S. history. When asked to interpret this omission, Felix stated: "I don't think they really did much" (interview, 12/15/15). Given that Felix had identified as "half Mexican," this exchange suggested that Felix did not identify with the historical actors that served as protagonists in his history classes or his historical perspectives. Rather, Felix described 
historical and contemporary examples of discrimination that clearly resonated with his experiences. For example, Felix exclaimed that it was "pretty messed up" when an antiimmigrant bias led to the exclusion of Chinese railroad workers from a photograph commemorating the completion of the Transcontinental Railroad (fieldnotes, 10/13/15). Felix similarly decried Donald Trump's rhetoric about “making all the Hispanics...get out of this country" (interview, 12/15/15). Felix contextualized Trump's comments by comparing him to the KKK. Felix explained that "there were more White people back then. I mean, yeah, some White people are nice, but some, they just don't like some sort of people" (interview, 12/15/15). Though Felix had identified as American- "because I was born here" - he clearly distanced himself from the "White people" who had historically discriminated against immigrants and continued to discriminate against Mexicans and Hispanics. Through Felix's descriptions of his historical perspectives, he demonstrated the centrality of these aspects of his identity, even as his use of the discrimination narrative revealed the dissonance between himself and the U.S. history he described. In the following section, I examine the case of another participant who identified similar themes in U.S. history.

"I would be a slave": The case of Maria. Maria was born in Garden View, Virginia, where she had lived her entire life. Maria explained that her "biological" family — including her mother-was from Honduras. She added that her step-dad was from Cuba and that she enjoyed learning about Cuban culture from him. Maria was identified as a bilingual student who had previously "exited" the ESL program at Jackson Heights. She described speaking "Spanglish" at home and selected the Honduran, American, and bilingual self-descriptor cards during her December interview. Maria had 
attended Garden View schools since kindergarten and had received a passing score on her sixth grade reading SOL test. Maria identified as a daughter, friend, and sister. In addition, she chose the athlete, actor, and comedian/class clown cards (interview, 12/14/15).

Maria's historical perspectives reflected the same outspoken and decisive analysis that marked her classroom participation. Frequently during Mr. Mitchell's instruction, Maria called out in whole group settings to voice disapproval of how a particular person or group had been treated in U.S. history. For example, Maria described examples of segregation as "messed up" (fieldnotes, 8/28/15) and labeled federal policy toward Native Americans as "bad" (fieldnotes, 10/5/15). In general, Maria distanced herself from the nation-building narrative of U.S. history. By contrast, Maria described learning about Honduran "heritage" as she described her affinity for the traditions and history of Honduras (interview, 12/14/15).

When Maria did identify with characters in U.S. history, she clearly reflected the discrimination narrative through pointedly casting herself in the role of a slave. Maria first spoke out about slavery when a class video depicted a fictional female slave during a slave auction, exclaiming that a White man had "touched her boobs" (fieldnotes, 9/9/15). During her interview the following week, Maria explained that Abraham Lincoln was important because if he "hadn't abolished slavery then I would be a slave right now" (interview, 9/17/15). Whereas the former incident focused on the gendered nature of the discrimination that enslaved Africans faced, Maria's interview comment made no such mention. As such, Maria's assertion that she "would be a slave" suggested that she viewed herself as "non-White" within a White-Black racial binary. This assessment is 
particularly interesting given that Maria would not typically be considered African American or Black based on her phenotype. However, during her December interview, Maria directly referenced her "skin color" when she reiterated her claim that she "would have been a slave" (interview, 12/14/15). When I asked Maria to interpret her classroom interaction regarding the treatment of the female slave, she explained that her response to the video reflected the "sexist" and "perverted" actions of the White man. She concluded that such conduct was "not good." In response to the initial finding that "many students name mostly White men as important in history," Maria stated that "most of the men that did good things were White, because when we came to the U.S.A. there was slavery....We got on a very rough start.” As before, Maria explicitly identified with historical figures who had "a very rough start" in the context of U.S. history. In sum, Maria's comments suggest that her female and "non-White" status served to mutually reinforce the centrality of the discrimination narrative within her historical perspectives, particularly as they were vividly captured in her discussion of slavery. In the following section, I present a final case based on another participant who also discussed race in the context of the discrimination narrative.

"I don't like the American": The case of Yonas. Yonas was born in Eritrea and had arrived in Garden City two years before the study began. According to school records, Yonas and his family had refugee status. Yonas reported speaking Tigrinya and knowing a little bit of Arabic and a few other languages. He was labeled as an emergent bilingual with a low-intermediate English proficiency as reflected in his level 3 WIDA score. Yonas had scored well below the passing level on the sixth grade reading SOL test. During his December interview, he identified as an athlete and a reader. He also 
selected the Honduran, Eritrean, and Ethiopian cards. While the later two self-descriptors reflected his family background, Yonas' connection to Honduras appeared to be aspirational as he uttered Spanish words and interacted socially with Honduran peers with increasing frequency as the semester progressed.

Yonas stands out as the only one of the eleven participants who did not employ the nation-building narrative when describing his historical perspectives. Two reasons for this appeared to be Yonas' limited exposure to U.S. history and his apparent difficulty in understanding Mr. Mitchell's instruction. As such, Yonas organized his historical perspectives using only the equality and discrimination narratives. Within these narratives, Yonas focused on notions of fairness and equality. For example, he nominated George Washington and Abraham Lincoln as historically significant because they "helped" others (interview, 12/8/15). Yonas similarly credited Martin Luther King, Jr. with "wanting Black people [to] be equal” (interview, 12/8/15). While Yonas' use of the equality narrative largely reflected the official curriculum, his use of the discrimination narrative provided insights into the ways in which identity served as a "site of struggle" (Norton, 2000, p. 127) for Yonas.

Over the course of the study, Yonas actively constructed an identity as a Honduran immigrant. By the December interview, Yonas had begun to change parts of his personal biography, claiming that his father was from Honduras. He also asserted that his father had told him about how the "KK" had killed his grandfather (interview, 12/8/15). While Yonas had rejected the racialized label "Black" as "racist" in other exchanges, his personalized story about the KKK reflected Yonas' understanding of "some White man...like the American, they're racist to the Black American" (interview, 
12/8/15). During the focus group interview, Yonas had similarly stated that he didn't "like the American" who represented anti-immigrant sentiments in a political cartoon (focus group, 11/19/15). In both instances, Yonas drew a distinction between "some White man" or "the American" who perpetrated discrimination and "the Black American" or immigrant who faced racism. Given this framing, Yonas' efforts to speak Spanish and claim Honduran heritage appear to reflect an agentive response to the negative, perhaps unattainable status of "White American" and the limiting, victimized status of "Black American." Particularly within the context of Mr. Mitchell's class and the broader Jackson Heights community, Yonas' decision to interact with and mimic peers like Javier and Maria may be seen as a "third way" that allowed him to forge a new identity. As such, Yonas' historical perspectives served to reinforce his complex identity negotiation (P. Lee, 2012; Norton, 2010) against the backdrop of the discrimination narrative. In summary, the three cases of Felix, Maria, and Yonas provide evidence of the complex interaction between multiple aspects of each student's identity and that student's historical perspectives. In the following section, I summarize the chapter and the findings from the present study.

\section{Chapter Summary}

In summary, the findings presented in this chapter suggest that the eleven case study students in this study described perspectives on U.S. history that largely reflected formal history instruction. In addition, I found that while describing their historical perspectives, the participants employed three schematic narrative templates (Barton \& Levstik, 2004; Carretero \& van Alphen, 2014; Peck, 2010; Wertsch, 2000; Wills, 2011): the nation-building narrative, the equality narrative, and the discrimination narrative. 
Across the classroom observations, interviews, and collected documents, students most frequently referenced the nation-building narrative based on concepts of progress and development. The participants also used the equality and discrimination narratives, particularly during student-initiated classroom and focus group interactions. These narratives reflected the importance of rights and inequality, respectively. When describing historical perspectives that reflected the nation-building narrative, students rarely referenced their own experiences or social identities. However, students did occasionally employ the equality and discrimination narratives in such a way that they bridged the formal history curriculum and their own historical perspectives. In these cases, aspects of students' identity served as secondary mediators of their historical perspectives. In the following chapter, I discuss the findings and identify potential implications from the present study. 


\section{CHAPTER V}

\section{DISCUSSION AND IMPLICATIONS}

In this chapter I discuss the findings for the present study, which are based on the following research questions:

- How do middle school emergent bilingual and bilingual students describe their perspectives on U.S. history?

- How do various student characteristics (e.g., English language proficiency, country of origin) interact with middle school emergent bilingual and bilingual students' perspectives on U.S. history?

Data analysis from this multiple case study generated findings that contribute to the growing literature on the historical perspectives of students from culturally and linguistically diverse backgrounds. First, the emergent bilingual and bilingual students in this study described historical perspectives that reflected the official U.S. history curriculum, which suggests that formal history instruction served as the primary source of students' historical knowledge. Second, the participants described historical perspectives that reflected three schematic narrative templates (Barton \& Levstik, 2004; Carretero \& van Alphen, 2014; Peck, 2010; Wertsch, 2000; Wills, 2011). Third, the participants employed the discrimination and equality narratives to bridge the divide between their own social identities and the formal U.S. history curriculum. 
The findings from the present study suggest that many factors influenced the historical perspectives of the middle school emergent bilingual and bilingual participants. First, the students in this study described the history they learned in school as authoritative, which suggests that the curriculum and instruction students encounter in classrooms wields significant power. Second, the fact that the participants' descriptions of U.S. history reflected three narratives suggests that culturally and linguistically diverse middle school students have the potential to organize historical knowledge in nuanced ways. Finally, the ways in which students employed the discrimination and equality narratives when reading themselves into their discussions of current events and U.S. history suggests that — as Parker (2010) asserted — U.S. history has the potential to inform students' identity. In this chapter, I discuss these findings in the context of the extant literature. I then present the limitations of the study, explore possible implications, and suggest directions for future research. Figure 16 provides a complete overview of the chapter.

\section{Overview of Chapter V}

Student Perspectives Reflect the Official Curriculum

Students Employ Narratives to Organize Historical Perspectives

Students Identify with (In)Equality in U.S. History

Limitations

Implications

For Research

For History Teachers

For Teacher Educators

Future Research

Chapter Summary

Figure 16. Overview of Chapter V

\section{Student Perspectives Reflect the Official Curriculum}

The participants in this study described historical perspectives that privileged formal history instruction and consistently reflected the official U.S. history curriculum. 
The close link between students' historical knowledge and the SOLs makes sense given that observations revealed that the instruction of the teachers closely aligned with the content outlined in the SOLs. Similarly, in interviews both Ms. Rogers and Mr. Mitchell identified the state standards as the primary factor that influenced how they determined "what to teach." Yet, while these findings about the teachers are consistent with qualitative research among Virginia history teachers (van Hover, 2006; Yoder \& van Hover, 2015) and the broader literature on curricular decision-making in standards-based settings (Au, 2007; Grant, 2010; Yeager \& van Hover, 2006), the findings regarding the students' adherence to the official curriculum raise interesting questions.

Data analysis suggests that the students in the present study privileged the content found in the SOLs, just as Ms. Rogers and Mr. Mitchell had in their day-to-day instruction. However, whereas research shows that in many standards-based settings teachers often teach to the standards (Au, 2007; Grant, 2010; Yeager \& van Hover, 2006), the literature on students' historical perspectives offers varied results. For example, Almarza (2001) and Busey (2013) each documented open resistance to U.S. history instruction among eighth grade Latina/o students. Almarza reported that Daniel, one of eighteen Mexican American participants from the Midwest, argued that his teacher "only taught about her past and her culture" (Almarza, 2001, p. 4). Busey similarly described how the participants in his study in the Southeastern United States separated themselves from the U.S. history taught in school, quoting Javier's racialized assessment: "In history we learn about the same races, either African Americans or White. I would like to learn more about our race, like Latinos" (Busey, 2013, p. 99). The majority of the South Korean immigrant students in Choi and colleagues' (2011) study also "expressed 
in part a negative perception and experience of learning social studies, especially US history" (p. 6). While the participants in the present study did occasionally critique history as being boring (Yonas, interview, 12/8/15) or difficult to understand (Marisol, interview, 12/18/15), they did not reject the history instruction outright or describe a "negative perception" in general.

Rather, the participants in the present study consistently voiced trust in schoolbased sources of historical knowledge above all other sources. When asked to identify trustworthy sources of historical knowledge, the participants nominated teachers and textbooks at the highest rate. Their approach is similar to that of the "Hispanic American" students in Dan and colleagues' (2010) survey of middle and high school students in West Texas. The Latina/o students in that study also identified history teachers and textbooks as the two most credible sources of historical information. In a study of 49 students in a Midwest eleventh grade U.S history classroom, Epstein (1998) similarly found that White students most frequently nominated the textbook and the teacher as trustworthy. These results differed from the Black students in the study who identified a family member as their first or second choice. Cuban American students in Terzian and Yeager's (2007) study of AP U.S. history students in South Florida also identified their families as significant sources of historical knowledge.

In short, the current study contributes to the small yet growing set of case studies that investigate historical perspectives among students of color. The divergent findings among these studies suggest that additional factors beyond racial and ethnic identity may also contribute to students' receptivity to formal U.S. history instruction. As well, the focus on student perspectives in the current study adds to the existing literature on which 
sources of history students find credible. While the research has provided varied results, the findings suggest that the sources of historical knowledge that students identify as trustworthy play an important role in mediating students' historical perspectives.

\section{Students Employ Narratives to Organize Historical Perspectives}

The research indicates that the historical narratives that students employ also mediate their historical perspectives. For example, the participants in the current study organized their historical knowledge using three schematic narrative templates (Barton \& Levstik, 2004; Carretero \& van Alphen, 2014; Peck, 2010; Wertsch, 2000; Wills, 2011). Each of the three narratives that I identified emerged from inductive data analysis in the current study. As the extant literature demonstrates that historical narratives serve as a fundamental cultural tool for understanding and sorting historical knowledge (Barton \& Levstik, 2004; Grant, 2003; Levstik \& Barton, 2008; VanSledright, 2008), previous research on students' historical perspectives has also utilized the construct of schematic narrative templates. In many cases, researchers have concluded that students of various cultural and linguistic backgrounds have described a "traditional" (e.g., An, 2009; Terzian \& Yeager, 2007) or "Eurocentric” (e.g., Choi et al., 2011; Epstein, 2000) narrative of U.S. history. As Table 17 illustrates, Epstein (2000) and Peck (2010) found that the participants in their studies employed a range of narratives. In her study of White and Black 11th grade students, Epstein presented findings based on the narrative of U.S. history that each of four students used. Peck similarly generated three narratives of Canadian national history based on the perspectives of the grade 12 students in her study. The students in the present study employed narratives that included similar notions of progress, equality, and discrimination to those presented in both Epstein and Peck's 
Table 17

Comparing Students' Narratives of National History

\begin{tabular}{|c|c|c|}
\hline $\begin{array}{l}\text { Emergent } \\
\text { Narrative }\end{array}$ & \multicolumn{2}{|c|}{ Narratives in Extant Literature } \\
\hline & $\begin{array}{c}\text { Epstein (2000) } \\
\text { 11th grade U.S. students }\end{array}$ & $\begin{array}{c}\text { Peck (2010) } \\
\text { Grade } 12 \text { Canadian students }\end{array}$ \\
\hline $\begin{array}{l}\text { The Nation- } \\
\text { Building } \\
\text { Narrative }\end{array}$ & $\begin{array}{l}\text { Traditional Eurocentric } \\
\text {-Andrea c constructed a } \\
\text { national history in which } \\
\text { Europeans and European } \\
\text { Americans discovered, } \\
\text { explored, colonized, } \\
\text { settled, and created a } \\
\text { nation" (p. 192). }\end{array}$ & $\begin{array}{l}\text { Founding of the Nation } \\
\text { "This narrative recounts } \\
\text { the history of the first } \\
\text { inhabitants of Canada } \\
\text { (before it was a nation) } \\
\text { and the events that 'built' } \\
\text { the country" (p. 594). }\end{array}$ \\
\hline $\begin{array}{l}\text { The Equality } \\
\text { Narrative }\end{array}$ & $\begin{array}{l}\text { Revisionist Eurocentric } \\
\text { - "Ellen constructed a } \\
\text { nation in which 18th- } \\
\text { century colonists } \\
\text { successfully fought for } \\
\text { independence, the } \\
\text { consequences of which } \\
\text { 'gave us freedoms we } \\
\text { have now'... she projected } \\
\text { a national identity based } \\
\text { on individual rights..." } \\
\text { (p. 196). }\end{array}$ & $\begin{array}{l}\text { Diverse and Harmonious Canada } \\
\text { "This narrative recounts } \\
\text { the history of Canadians } \\
\text { overcoming prejudice and } \\
\text { discrimination in order to } \\
\text { establish a harmonious, } \\
\text { multicultural, } \\
\text { multinational Canadian } \\
\text { identity" (p. 594). }\end{array}$ \\
\hline $\begin{array}{l}\text { The } \\
\text { Discrimination } \\
\text { Narrative }\end{array}$ & $\begin{array}{l}\text { Double Historical Consciousness } \\
\text { "Tyrone's }{ }^{\text {b narrative }} \\
\text { began with European } \\
\text { exploration and } \\
\text { colonization and their } \\
\text { effects on Native } \\
\text { Americans and African } \\
\text { Americans. Europeans } \\
\text { enslaved African } \\
\text { Americans because they } \\
\text { 'figured it was the } \\
\text { cheapest way to do the } \\
\text { work without having to } \\
\text { pay for it"” (p. 200). }\end{array}$ & $\begin{array}{l}\text { Diverse but Conflicted Canada } \\
\text { - "This narrative recounts } \\
\text { the history of } \\
\text { multiculturalism in } \\
\text { Canada, with an explicit } \\
\text { focus on conflicts and } \\
\text { tensions that have } \\
\text { arisen..." (p. 595). }\end{array}$ \\
\hline
\end{tabular}

Note. Epstein (2000) presented a fourth narrative - the "Afrocentric perspective" - which did not align with the historical perspectives of the participants in the present study or Peck's (2010) study. ${ }^{\text {a }}$ Student identified as European American. ${ }^{\text {b}}$ Student identified as African American. 
findings. However, whereas Epstein attributed each narrative to a particular participant or group of students, I found that nine of the eleven participants in the present study used all three narratives to organize their perspectives on U.S. history. Peck similarly found that some of the participants in her study employed multiple narratives when they described their perspectives on Canadian history.

The nation-building narrative in the present study reflects many of the elements of the traditional Eurocentric narrative of U.S. history. As research has demonstrated, history textbooks (e.g., Alridge, 2006; Hilburn \& Fitchett, 2012; Loewen, 1995; Loewen, 2010; Suh et al., 2015), history standards (e.g., C. B. Anderson \& Metzger, 2011; Journell, 2008, 2009; Shear et al., 2015; Vasquez Heilig et al., 2012), and history instruction (e.g., Barton, 2001; Barton \& Levstik, 2004; Grant, 2003; VanSledright, 2008) typically focus on this traditional narrative. In Epstein's (2000) study, Andrea's description of European exploration and conquest reflected the nation-building narrative. Peck (2010) similarly described the focus on "events that 'built' the country" (p. 594) as central to the "Founding of the Nation" narrative of Canadian history. Participants in the present study also emphasized the role of explorers and war in "building" the United States. Across these studies, students who employed the nation-building narrative attributed historical significance to the historical actors, events, and processes that contributed to national institutions.

Ten of the participants in the current study—all but Marisol—also reflected the equality and discrimination narratives in their historical perspectives. The centrality of rights and discrimination in these narratives contributes to an understanding of the two narratives as two sides of the same coin. Students in Peck's (2010) study employed the 
"Diverse and Harmonious Canada" narrative in much the same way as students in the present study used the equality narrative. In each case, a focus on "overcoming prejudice and discrimination" (Peck, 2010, p. 594) contributed to a shared national identity. In her "Revisionist Eurocentric" narrative, Ellen similarly connoted the role of freedom and individual rights as part of a perceived "national identity" (Epstein, 2000, p. 196).

Conversely, when employing the discrimination narrative, students across the three studies focused on the breakdown of a singular or cohesive national identity. For example, Epstein (2000) reported that Tyrone built his "Double Historical Consciousness" narrative around the concept of European Americans exploiting other groups - most notably Native Americans and African Americans. Peck (2010) also described "an explicit focus on conflicts and tensions" as central to the "Diverse but Conflicted Canada" narrative reflected in the historical perspectives of some of her participants. In the current study, students employed the discrimination narrative when they described slavery and other examples of "racist" inequality. Together these examples of students' historical perspectives on national history provide evidence of the potential for middle and high school students to use the cultural tool of "schematic narrative templates" (Barton \& Levstik, 2004; Carretero \& van Alphen, 2014; Peck, 2010; Wertsch, 2000; Wills, 2011) to organize their historical perspectives in a complex and nuanced manner. Furthermore, the employment of the discrimination narrative may have provided students in the three studies with a structure for addressing "controversial histories" that are typically "silenced or avoided" (Salinas et al., 2012, p. 20). In the following section, I discuss the ways in which students' use of narratives provided insights into the relationship between student identity and national history. 


\section{Students Identify with (In)Equality in U.S. History}

While the participants in the present study reflected three narratives in their historical perspectives, when referring to aspects of their own identity they most often employed the discrimination or equality narrative as part of their comparisons between the past and the present. This focus on (in)equality suggests that the participants may have experienced conflict between their individual identities and the national identity presented in the official U.S. history curriculum. As such, while the discrimination and equality narratives provided a bridge between students' experiences and the official curriculum, the ways in which students positioned themselves in relationship to current events and U.S. history suggested that they may have viewed themselves as the "other" (Carretero, Rodríguez-Moneo, \& Asensio, 2012, p. 2) in relationship to the "imagined communities" (B. Anderson, 1991) and notions of an "American" identity found in the official curriculum.

Through highlighting (in)equality in their descriptions of U.S. history, the students demonstrated that they identified with historical figures who were struggling in the absence or pursuit of equality. For example, Maria identified the end of slavery as an important event in U.S. history, stating, “If Abraham Lincoln hadn't abolished slavery then I would be a slave right now" (interview, 9/17/15). Such an assessment reflected a Black-White binary in which U.S. history was "Black and White" (Yousuf, interview, 12/9/15), with "Americans" being the "White man" (Yonas, interview, 12/8/15) and all others subject to discrimination. An $(2009,2012)$ similarly found that her Korean American participants equated being "American" with "White people." Santiago (2013) found a similar conceptualization of a Black-White binary when 11th grade Mexican- 
American and Mexican immigrant students in her study conflated the Mendez $v$.

Westminster School District civil rights case with Brown v. Board of Education, treating the Mendez case "as if it were African-American history, but with protagonists of a different skin color" (p. 37). In reference to the absence of other ethnic identities from the curriculum, Javier asserted, "I've mostly never heard of a Hispanic guy in history in all my years" (interview, 12/16/15). Felix also stated that he had not learned about Latinos in U.S. history, interpreting their absence as an indication no Latina/o had been historically significant (interview, 12/15/15). While there were a few instances in which participants used first-person pronouns while employing the nation-building narrative, these isolated examples served to emphasize the overall absence of such terms as "we" and "us." In this way, the participants' identification with the nation-building narrative appeared to be limited in comparison to the White students who regularly used terms like "we" and "our" when describing U.S. history in previous studies (e.g., Barton, 2012; Epstein, 2009; VanSledright, 2008).

The participants in the present study also discussed issues of (in)equality in relationship to aspects of their identity beyond race and ethnicity. Many students demonstrated how their own unique positionality—often reflective of a particular "outsider" identity—interacted with their historical perspectives. For example, two female students, Isabel and Maria, discussed historical examples of gender-based discrimination and efforts to secure equality for women. Similarly, a student who was identified as a refugee, Gebre, discussed the plight of Syrian refugees. Two Muslim students, Aras and Yousuf, described Donald Trump's rhetoric about Muslims as prejudiced and discriminatory. Felix, Santiago, and other participants also identified 
Trump's plan to deport illegal immigrants as "racist" and "dumb!" (focus group, 11/24/15). Levstik and Barton (2008) have identified the limitations of the traditional narrative of U.S. history: "The traditional story, focusing on national politics, elite society, and traditional heroes, had been elegant, linear and unconfusing precisely because it left out so much" (p. 100). The findings from this study suggest that this assessment might be extended further to specify that traditional narratives of U.S. history have not only "left out so much," but also left out so many, including historical figures that reflect the identities of students, such as women, refugees, Muslims, immigrants, and Latinos.

The ways in which students described and subsequently referenced their own identities while discussing historical and contemporary narratives of (in)equality reflect a complex and multifaceted conceptualization of identity (P. Lee, 2012; Norton, 2010). The findings further suggest that the notion of "identity as a site of struggle" (Norton, 2000, p. 127) can enrich the study of the historical perspectives. For example, Norton (2013) argued that "a focus on imagined communities in language learning enables us to explore how learners' affiliation with such communities might affect their learning trajectories" (p. 8). Analyzing the findings of the current study through the lens of "imagined communities" suggests that student identity may inform language learning and history learning in similar ways. For just as the "learners' affiliation with [imagined] communities" may mediate language learning, so also may historical "narratives make certain identity categories available that allow participants to position themselves and others as being this or that kind of person" (Bermúdez, 2012, p. 207). 
In summary, the findings in the present study emphasize the conceptual link between students' identity and historical perspectives. The findings reflect Carretero, Rodríguez-Moneo and Asensio's (2012) assertion that “the teaching of history is still intimately related to the construction of individual identity and the transmission of collective memory" (p. 1). In the present study, the degree to which the participants' historical perspectives reflected the official U.S. history curriculum suggests that the history instruction they received served as a conduit for the "transmission" of history knowledge. In addition, the finding that students identified most closely with examples of (in)equality in U.S. history suggests that the history curriculum may have contributed to an "outsider" identity among some of the participants. Van Alphen and Asensio (2012) contend that such findings present a moral imperative for history educators: "if a child cannot identify with the master narrative told in school, because her community was not represented in that historical account, we feel that a voice has been smothered and that human rights are violated" (p. 353). To the extent that the participants in this bounded case study represent "extreme" or "maximum variation" cases (Marshall \& Rossman, 2011; Teddlie \& Tashakkori, 2009), the present study may offer "voice" to students and perspectives that have too often been "smothered." In the following sections I explore limitations of the present study and then examine potential implications.

\section{Limitations}

The qualitative case study design that I used for the present study provided important opportunities for the inclusion of emic perspectives (Erickson \& Schultz, 1992; Marshall \& Rossman, 2011) in response to the research questions. Furthermore, the purposeful selection of participants through extreme case (Teddlie \& Tashakkori, 2009) 
or maximum variation sampling (Marshall \& Rossman, 2011) yielded historical perspectives from a diverse array of students. In considering implications of the present study, however, it is important to note that the findings reflect the bounded cases of eleven individuals. This small sample size prevented the inclusion of students from all the theoretically relevant groups. In addition, the historical perspectives of the participants are their own (Epstein, 2009) and cannot be generalized to other populations or considered representative of all emergent bilingual or bilingual students (Coffey \& Atkinson, 1996; Creswell, 2009; Marshall \& Rossman, 2011).

I designed the present study to maximize data collection and provide for prolonged observation (Erickson, 1986; Hood, 2009). I also provided for the triangulation of data sources, as well as member checking (during the December interviews) and analytic memos in order to strengthen the trustworthiness of the findings (Erickson, 1986; Krefting, 1999). Having taken these steps, I must recognize that the findings are limited by the type of data I was able to collect. Specifically, the data affords few insights into the many sources of historical knowledge outside of school that may have informed the participants' historical perspectives.

Furthermore, I must recognize that the findings and conclusions reflect the "double hermeneutic" that resulted from both my own interpretations and the participants' interpretations (Flyvbjerg, 2001, p. 33). Accordingly, my own positionality as a monolingual, White male informed both my perspectives and the ways in which my participants interacted with me. During the Jackson Heights focus group, Javier made a comment that hinted at how my presence may have impacted how some students described their historical perspectives. When talking about immigration, Yonas said: "I 
don't like the American...” In response, Javier indicated he was talking about me when he stated: "You're hurting his feelings" (focus group, 11/19/15). Javier's single statement demonstrated the potential impact of my own positionality—as "an American" in this case - and presence on the participants. In order to minimize the potential for selfcensoring confirmation bias, I maintained an "observer as nonparticipant" (Marshall \& Rossman, 2011, p. 143) stance during the classroom observations, and structured the interviews with both open- and close-ended questions (Barbour, 2007; Kvale, 2007; Schwartz-Shea \& Yanow, 2012). In the following section, I examine potential implications from the present study.

\section{Implications}

In this section, I explore the potential implications of the findings from the present study. I first describe possible implications for research. I next examine implications for history teachers. I conclude with implications for teacher educators.

\section{For Research}

The present study has the potential to add to the literature on the teaching and learning of history. The findings contribute most directly to the research on the historical perspectives of students from culturally and linguistically diverse backgrounds (e.g., Barton, 2008; Epstein, 2009; Peck, 2010), as well as the broader bodies of knowledge regarding U.S. history education (e.g., VanSledright, 2008; Wineburg \& Monte-Sano, 2008b) and the educative experiences of emergent bilingual and bilingual students (e.g., Kibler \& Valdés, 2016; Norton \& McKinney, 2011).

This study also informs my existing research agenda as denoted in the emergent conceptual framework based on Grant's (2003) three tenets of ambitious teaching and 


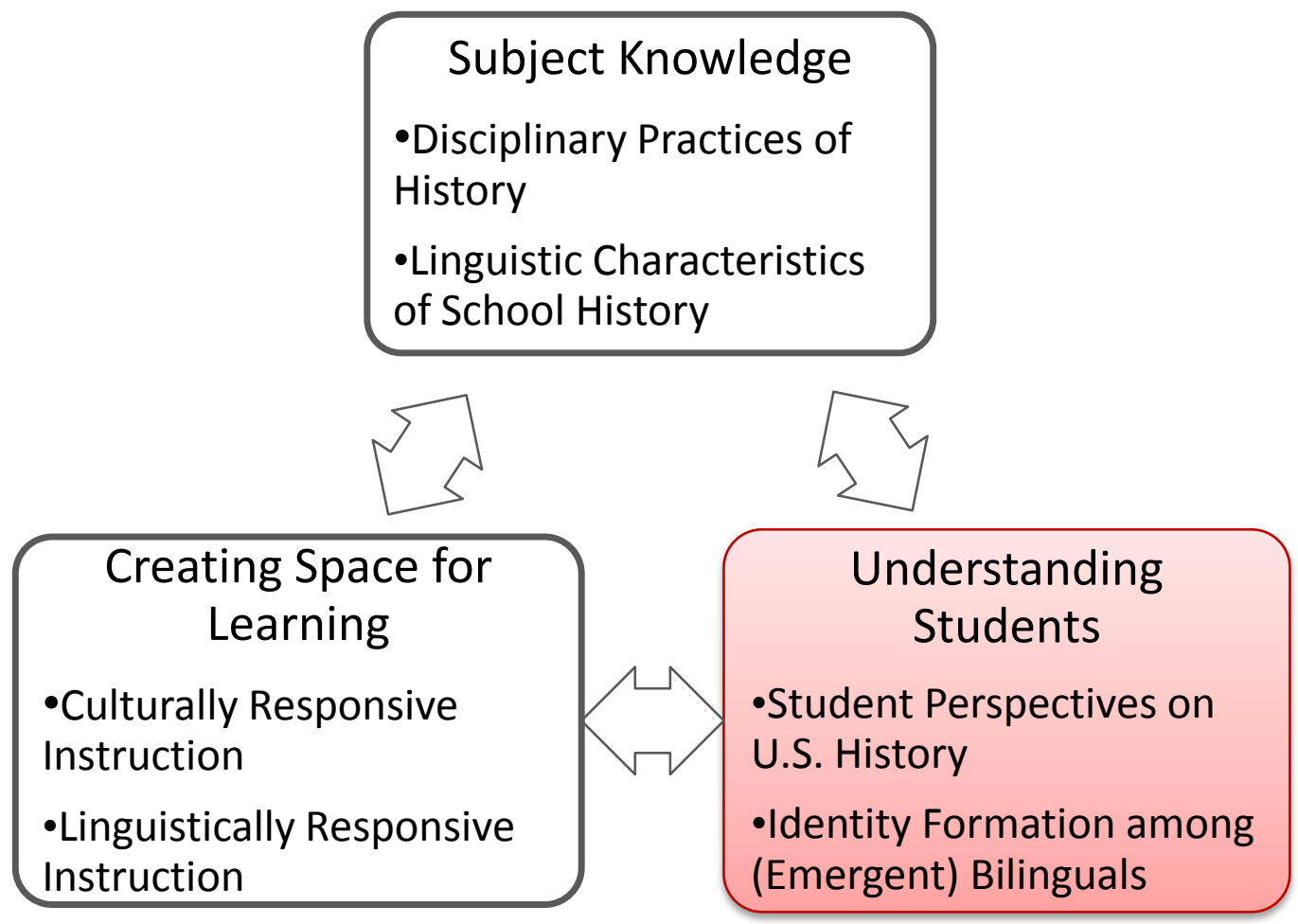

Figure 87. Ambitious Teaching and Learning of U.S. History for (Emergent) Bilinguals Framework

learning (see Figure 17). For each of these tenets I have identified two additional areas of focus based on the unique positionality of (emergent) bilinguals. For example, Grant asserted that history teachers need "subject knowledge," explaining that educators should "know well their subject matter and see within it the potential enrich their students' lives" (p. xi). In response, I have proposed that U.S. history teachers will be more effective when they understand the linguistic characteristics of school history (e.g., de Oliveira, 2011; Schleppegrell, 2004) and the disciplinary practices involved in "doing" history (e.g., Levstik, 2008; NCSS, 2013; Vansledright, 2010b). The present study aligns most closely with the second tenet of "understanding students," which Grant described as knowing "the kinds of lives [students] lead, how they think about and perceive the world, and that they are capable of far more than they and most others believe" (p. xi). This 
study demonstrated how an in depth analysis of students' backgrounds, experiences, and self-selected identities can provide a rich description of (emergent) bilingual students on both the individual and group level. Furthermore, a systematic examination of students' perspectives on U.S. history revealed that many factors, including students' English language proficiency, social context, and various identity markers mediated the ways in which students "think about and perceive the world." Finally, students' complex attributions of historical significance and use of multiple schematic narrative templates support Grant's assertion that students are "capable of far more than they and most others believe." In sum, the findings from this study of (emergent) bilinguals suggest that a greater "understanding [of] students" may benefit from (a) an awareness of student perspectives on U.S. history, and (b) identity formation among (emergent) bilinguals. The third tenet that Grant identified is the "creating space for learning," which he described as the ability for teachers "to create the necessary space for themselves and their students in environments that may not appreciate the efforts of either" (p. xi). Given the findings of an apparent divide between the traditional, Eurocentric narrative of U.S history and the participants' own sense of identity, I contend that history teachers need to "create space for learning" within the contemporary social context and the official curriculum. To this end, I propose that (emergent) bilinguals may benefit from history teachers engaging in culturally responsive instruction (Epstein et al., 2011; Martell, 2013; Yoder et al., 2016) and linguistically responsive instruction (Lucas \& Villegas, 2010; Lucas et al., 2008). I explore the potential implications for history teachers in the following section. 


\section{For History Teachers}

The findings from the present study suggest that the participants relied on their history teachers for historical knowledge. For example, the participants nominated their history teachers textbooks as trustworthy sources. In addition, in their descriptions of U.S. history, the students almost exclusively identified historical actors and events that were a part of their previous history instruction. As such, the present study emphasizes the importance of high quality history instruction. Previous research suggests that notions of culturally responsive and linguistically responsive have the potential to inform history teachers' instruction in ways that respond to the background knowledge and experiences of (emergent) bilinguals (Jaffee, 2016; Yoder et al., 2016).

In short, culturally responsive instruction provides a framework for understanding teaching and learning that builds on the unique strengths of students from culturally and linguistically diverse populations. Gay (2000) argues that culturally responsive instruction "includes accurate information about the cultures and contributions of different ethnic groups, as well as moral and ethical dilemmas about their treatment in the U.S., the redistribution of power and privilege, and the deconstruction of academic racism and hegemony" (p. 213-214). Such an approach has particular implications for the teaching of U.S. history, particularly given the findings in the present study regarding the centrality of ethnic identity and the prevalence of the discrimination narrative with the participants' historical perspectives. A small number of studies address the teaching and learning of U.S. history among emergent bilinguals. These studies provide insights into culturally responsive instruction, focusing particularly on the inclusion of multiethnic history in the curriculum and the incorporation of instructional practices that allow 
emergent bilinguals to participate fully. The primary implication of the small body of research on culturally responsive history instruction is that "the presence of [emergent bilinguals] in the history classroom should impact what is being taught, in addition to how it is being taught" (Yoder et al., 2016, p. 31).

The construct of linguistically responsive instruction builds on an understanding that emergent bilinguals and other linguistically diverse students bring particular strengths and face unique challenges when encountering the language of schooling. In the present study, these challenges included the examples of Marisol and Yonas' "not understanding" during the course of Mr. Mitchell's instruction. While Gutiérrez and colleagues (Gutiérrez \& Orellana, 2006; Gutierrez \& Rogoff, 2003; Orellana \& Gutiérrez, 2006) caution educators and researchers against the use of deficit language when describing emergent bilinguals, recognizing the unique language of school history provides a starting point for identifying specific approaches that may increase understanding. In an earlier action research study, I reported (Yoder, 2013) on the application of the Structured Academic Discussion instructional model in a series of U.S. history units in my seventh grade classroom. In that analysis I found that the incorporation of sentence frames and speaking and writing prompts supported both student engagement and increased language production. Bunch $(2006,2009)$ reported similar findings in the course of his study, also with seventh grade emergent bilinguals, in which students worked in groups to analyze primary historical sources and prepare an oral presentation. Together these studies demonstrate potential applications of the notion of scaffolding instruction as a form of linguistically responsive instruction. They provide examples of instructional approaches that can support emergent bilinguals in producing 
"language to analyze events and make arguments" in a history context (DiCerbo et al., 2014, p. 28). They further speak to the common concern that history teachers not simplify content knowledge when teaching emergent bilinguals, but rather provide the scaffolds and supports to make content accessible to students (Fritzen, 2011;

Schleppegrell et al., 2004; Short, 2002; Twyman, Ketterlin-Geller, McCoy, \& Tindal, 2003). In the following section, I explore implications for teacher educators.

\section{For Teacher Educators}

The implications for teacher educators largely reflect the types of teacher preparation needed to support culturally and linguistically responsive instruction. In order for teachers to have the knowledge and skills to effectively provide such history instruction, teacher educators must provide preservice teachers with relevant theory, instructional approaches, and opportunities to teach emergent bilinguals while under appropriate supervision. DiCerbo and colleagues (2014) contend that the first step is for history teachers to internalize a sense of ownership for (future) emergent bilingual students (see also Lucas \& Villegas, 2010). Bunch (2013) presents the concept of "pedagogical language knowledge" as a means of helping content teachers "purposefully enact opportunities for the development of language and literacy in and through teaching the core curricular content, understandings, and activities that teachers are responsible for...teaching in the first place" (p. 298). In short, teachers will benefit from opportunities to develop attitudes and content knowledge related to the cultural and linguistic dimensions of both the history subject matter and their future students.

In addition to these language-focused suggestions, recent literature from the field of history education yields specific suggestions on how teacher training may enrich 
preservice teachers' conceptual knowledge of the U.S. history content. Barton and Avery (2016) found that "many beginning and veteran teachers do not understand history as a social construction of the past" (p.36). They contend that what a history teacher believes about the nature of history - "such as whether it consists of a body of names, events, and dates to be learned, or of interpretations of the past based on evidence and subject to revision" (p. 35) - is the most important knowledge a teacher can have. In order to engender understandings of history as a "social construction," teacher educators (and history professors) could engage preservice teachers in inquiry-based activities with the goal of helping future teachers explore the interpretive nature of a disciplinary approach to history. Such an experience may then open the door for preservice teachers to engage in what Salinas and colleagues (2012) refer to as "critical historical thinking." Salinas and colleagues (2012) describe critical historical thinking as a process whereby future teachers "(re)examine history through new voices that have been marginalized in the traditional curricular metanarratives" (p. 27). In a case study with seven preservice teachers who demonstrated a "commitment to more critical notions of the past," Salinas and Blevins (2014) examined the ways in which preservice teachers discussed their own engagement in and responses to the Student as Historian project and related coursework. The authors found that the preservice teachers confronted "untruths" in the traditional U.S. history narrative (p.41), and subsequently identified the potential of historical inquiry to serve as a "pedagogy of action" that could yield counter-narratives. These findings suggest that evaluating the official U.S. history curriculum as part of teacher preparation may enrich future teachers' understanding of the nature of history. Such an orientation may, in turn, help teachers support the types of historical disciplinary 
practices that reflect the principles of culturally responsive instruction discussed in the previous section. In the final section below, I explore possible implications for future research.

\section{Future Research}

The findings from the present study prompt many new questions that may contribute to future research. In this section I discuss suggestions for extending the findings in order to better understand students' historical perspectives. First, to extend the finding that the participants' historical perspectives largely reflected the official U.S. history curriculum, future research could include study among different populations and in different contexts. Such inquiry may lend to a broader understanding of the various factors that may influence this process and could explore the following questions: How do middle and high schools students describe similar or different experiences in U.S. history classrooms? In what ways does the U.S. history curriculum taught in various settings (i.e., states without history standards, schools that have ethnic studies programs) influence students' historical perspectives?

Second, to build on the finding that the participants reflected three narratives of U.S. history, I propose future research into students' development and use of narratives and related cultural tools. Longitudinal studies may be particularly informative. For example, studying a particular student or cohort over the span of two to four years might provide insights into how multiple U.S. history classes and other student experiences contribute to continuity or change in students' historical perspectives. Such research might address such questions as: How do the ways in which students describe their historical perspectives change over time? In what ways do the (similar or different) 
narratives that students encounter over time contribute to their own historical perspectives?

Finally, to further explore the finding that students employed the (in)equality narrative when identifying with U.S. history, future research could utilize different frameworks and methodologies. For example, future study could extend Salinas and colleagues' $(2012,2014)$ work on critical historical thinking to include K-12 students. Intervention studies may also add depth to the existing research and allow for inquiry into the following questions: How does U.S. history instruction that includes the perspectives of historically marginalized groups (i.e., immigrants, women, Muslims, Latinos) influence the ways in which students identify with the curriculum? To what extent do students reflect their own positionality in the narratives they develop through a "pedagogy of action"?

\section{Chapter Summary}

In this chapter I have discussed the findings from the present study in relationship to the extant literature. The data analysis from the study revealed that students reflected the official U.S. history curriculum in their own historical perspectives. As they described their perspectives on U.S. history, the participants employed three narratives: the nation-building narrative, the equality narrative, and the discrimination narrative. When students identified with the formal U.S. history curriculum, their comparisons between the present and the past most often reflected the discrimination or equality narratives. These findings highlight the influence of the U.S. history taught in schools, as well as the agency of the participants who operationalized different frameworks based their own positionality. The findings also support an understanding of the U.S. history 
classroom as a place where notions of identity are either explicitly or implicitly addressed.

The findings from the present study have potential implications for research and practice. First, the findings add to the knowledge base on the teaching and learning of history among students from diverse cultural and linguistic backgrounds. Second, the findings suggest that teachers should make history instruction more culturally and linguistically response. Third, they contribute to an understanding that history teachers need training that prepares them to effectively engage students from diverse cultural and linguistic backgrounds. In the final section of the chapter, I conclude with potential directions for future research. 


\section{References}

No Child Left Behind Act of 2001, Pub. L. No. 107-110 § 115, Stat. 1425 (2002).

Addy, N. D. A. (2015). Culturally and linguistically diverse students and the power of labels. The High School Journal, 98, 205-207. doi: 10.1353/hsj.2015.0004

Alimoradian, K. (2014). "Makes me feel more Aussie": Ethnic identity and vocative mate in Australia. Australian Journal of Linguistics, 34, 599-623. doi:

$10.1080 / 07268602.2014 .929083$

Almarza, D. J. (2001). Contexts shaping minority language students' perceptions of American history. Journal of Social Studies Research, 25(2), 4-22.

Alridge, D. P. (2006). The limits of master narratives in history textbooks: An analysis of representations of Martin Luther King, Jr. Teachers College Record, 108(4), 662686.

Amaral, O. M., \& Garrison, L. (2007). Developing skills for English learners through social sciences. Multicultural Education, 14(4), 28-30.

An, S. (2009). Learning US history in an age of globalization and transnational migration. Journal of Curriculum Studies, 41, 763-787. doi: $10.1080 / 00220270903095993$

An, S. (2012). Korean American high school students' perspectives on U.S. history. Social Studies, 103, 12-19. doi: 10.1080/00377996.2011.581711

Anderson, B. (1991). Imagined communities: Reflections on the origin and spread of nationalism (2nd ed.). New York, NY: Verso.

Anderson, C. B., \& Metzger, S. A. (2011). Slavery, the Civil War era, and African American representation in U.S. History: An analysis of four states' academic 
standards. Theory \& Research in Social Education, 39, 393-415. doi:

$10.1080 / 00933104.2011 .10473460$

Anderson, K. L. (2013). Cross-cultural programs at Eastern Mennonite University: A counter-narrative to study abroad (Master's thesis). Available from ProQuest Dissertations and Theses database. (UMI No. 1539906)

Athanases, S. Z., \& de Oliveira, L. C. (2014). Scaffolding versus routine support for Latina/o youth in an urban school: Tensions in building toward disciplinary literacy. Journal of Literacy Research, 46, 263-299. doi:

$10.1177 / 1086296 \times 14535328$

$\mathrm{Au}, \mathrm{W}$. (2007). High-stakes testing and curricular control: A qualitative metasynthesis. Educational Researcher, 36, 258-267. doi: 10.3102/0013189x07306523

Aud, S., Hussar, W., Johnson, G., Kena, E., Roth, E., Manning, E., et al. (2012). The condition of education 2012. NCES 2012-045. Department of Education, National Center on Education Statistics. Washington, DC. Retrieved from http://nces.ed.gov/pubsearch

Aukerman, M. (2007). A culpable CALP: Rethinking the conversational/academic language proficiency distinction in early literacy instruction. The Reading Teacher, 60, 626-635. doi: 10.2307/20204516

Banks, J. A. (2002). An introduction to multicultural education (3rd ed.). Boston: Allyn \& Bacon.

Barbour, R. (2007). Doing focus groups. Thousand Oaks, CA: SAGE.

Barton, K. C. (2001). A sociocultural perspective on children's understanding of historical change: Comparative findings from Northern Ireland and the United 
States. American Educational Research Journal, 38, 881-913. doi:

$10.2307 / 3202506$

Barton, K. C. (2005). "Best not to forget them": Secondary students' judgments of historical significance in Northern Ireland. Theory \& Research in Social Education, 33(1), 9-44. doi: 10.1080/00933104.2005.10473270

Barton, K. C. (2008). Research on students' ideas about history. In L. S. Levstik \& C. A. Tyson (Eds.), Handbook of research in social studies education (pp. 239-258). New York, NY: Routledge.

Barton, K. C. (2012). School history as a resource for constructing identities: Implications for research from the United States, Northern Ireland, and New Zealand. In M. Carretero, M. Asensio \& M. Rodríguez-Moneo (Eds.), History education and the construction of national identities (pp. 93-108). Charlotte, NC: Information Age.

Barton, K. C. (2015). Elicitation techniques: Getting people to talk about ideas they don't usually talk about. Theory \& Research in Social Education, 43(2), 179-205. doi: $10.1080 / 00933104.2015 .1034392$

Barton, K. C., \& Avery, P. G. (2016). Research on social studies education: Diverse students, settings, and methods. In D. H. Gitomer \& C. A. Bell (Eds.), Handbook of research on teaching ( $5^{\text {th }}$ ed., pp. 985-1038). Washington, DC: American Educational Research Association.

Barton, K. C., \& Levstik, L. S. (2004). Teaching history for the common good. Mahweh, NJ: Lawrence Erlbaum Associates. 
Barton, K. C., \& Levstik, L. S. (2010). Why don't more history teachers engage students in interpretation? In W. C. Parker (Ed.), Social studies today: Research \& practice (pp. 35-42). New York, NY: Routledge.

Barton, K. C., \& McCully, A. W. (2005). History, identity, and the school curriculum in Northern Ireland: An empirical study of secondary students' ideas and perspectives. Journal of Curriculum Studies, 37(1), 85-116. doi:

$10.1080 / 0022027032000266070$

Barton, K. C., \& McCully, A. W. (2010). "You can form your own point of view": Internally persuasive discourse in Northern Ireland students' encounters with history. Teachers College Record, 112(1), 142-181.

Barton, K. C., \& McCully, A. W. (2012). Trying to "see things differently": Northern Ireland students' struggle to understand alternative historical perspectives. Theory \& Research in Social Education, 40, 371-408. doi:

$10.1080 / 00933104.2012 .710928$

Bermúdez, A. (2012). The discursive negotiation of narratives and identities in learning history. In M. Carretero, M. Asensio \& M. Rodríguez-Moneo (Eds.), History education and the construction of national identities (pp. 203-219). Charlotte, NC: Information Age.

Block, D. (2003). The social turn in second language acquisition. Washington, DC: Georgetown University Press.

Block, D. (2007). The rise of identity in SLA research, post Firth and Wagner (1997). The Modern Language Journal, 91, 863-876. doi: 10.2307/4626137 
Bradshaw, M. (2006). Creating controversy in the classroom: making progress with historical significance. Teaching History, 125, 18-25.

Brooks, S. (2011). Historical empathy as perspective recognition and care in one secondary social studies classroom. Theory \& Research in Social Education, 39(2), 166-202. doi: 10.1080/00933104.2011.10473452

Brophy, J., \& Alleman, J. (2008). Early elementary social studies. In L. S. Levstik \& C. A. Tyson (Eds.), Handbook of research in social studies education (pp. 33-49). New York, NY: Routledge.

Brown, C. L. (2007). Supporting English language learners in content-reading. Reading Improvement, 44(1), 32-39.

Brown, K. D. (2011). Breaking the cycle of Sisyphus: Social education and the acquisition of critical sociocultural knowledge about race and racism in the United States. The Social Studies, 102, 249-255. doi:

$10.1080 / 00377996.2011 .563726$

Bumgarner, E., \& Lin, M. (2014). Hispanic immigrant children's English language acquisition: The role of socioeconomic status and early care arrangement. Early Education and Development, 25, 515-529. doi: 10.1080/10409289.2013.822230

Bunch, G. C. (2006). "Academic English" in the 7th grade: Broadening the lens, expanding access. Journal of English for Academic Purposes, 5, 284-301. doi: 10.1016/j.jeap.2006.08.007

Bunch, G. C. (2009). "Going up there”: Challenges and opportunities for language minority students during a mainstream classroom speech event. Linguistics and Education, 20(2), 81-108. doi: 10.1016/j.linged.2009.04.001 
Bunch, G. C. (2010). Preparing mainstream secondary content-area teachers to facilitate English language learners' development of academic language. National Society for the Study of Education Yearbook, 109, 351-383.

Bunch, G. C. (2013). Pedagogical language knowledge: Preparing mainstream teachers for English learners in the new standards era. Review of Research in Education, 37, 298-341. doi: 10.3102/0091732X12461772

Bunch, G. C. (2014). The language of ideas and the language of display: Reconceptualizing "academic language" in linguistically diverse classrooms. International Multilingual Research Journal, 8(1), 70-86. doi: $10.1080 / 19313152.2014 .852431$

Busey, C. L. (2013). The Latina/o student's experience in social studies: A phenomenological study of eighth-grade students (Doctoral dissertation). Retrieved from http://etd.fcla.edu/CF/CFE0004825/Christopher_Busey_Dissertation.pdf

Carr, E. H. (1961). What is history? New York, NY: Vintage Books.

Carretero, M., Asensio, M., \& Rodríguez-Moneo, M. (Eds.). (2012). History education and the construction of national identities. Charlotte, NC: Information Age.

Carretero, M., Rodríguez-Moneo, M., \& Asensio, M. (2012). History education and the construction of a national identity. In M. Carretero, M. Asensio \& M. RodríguezMoneo (Eds.), History education and the construction of national identities (pp. 1-16). Charlotte, NC: Information Age. 
Carretero, M., \& van Alphen, F. (2014). Do master narratives change among high school students? A characterization of how national history is represented. Cognition and Instruction, 32, 290-312. doi: 10.1080/07370008.2014.919298

Carter, P. L. (2012). Stubborn roots: Races, culture, and inequality in U.S. and South African schools. New York, NY: Oxford University Press.

Casanave, C. P. (2009). Writing up your research. In J. Heigham \& R. A. Croker (Eds.), Qualitative research in applied linguistics: A practical introduction (pp. 288305). New York, NY: Palgrave Macmillan.

Ceginskas, V. (2010). Being "the strange one" or "like everybody else": School education and the negotiation of multilingual identity. International Journal of Multilingualism, 7(3), 211-224. doi: 10.1080/14790711003660476

Center for Public Education. (2012). The United States of education: The changing demographics of the United States and their schools. Retrieved from http://www.centerforpubliceducation.org/You-May-Also-Be-Interested-Inlanding-page-level/Organizing-a-School-YMABI/The-United-States-ofeducation-The-changing-demographics-of-the-United-States-and-theirschools.html

Cercadillo, L. (2006). "Maybe they haven't decided yet what is right": English and Spanish perspectives on teaching significance. Teaching History, 125, 6-9.

Chick, K. A. (2006). Gender balance in K-12 American history textbooks. Social Studies Research and Practice, 1(3), 284-290.

Chick, K. A., \& Corle, S. (2012). A gender analysis of NCSS notable trade books for the intermediate grades. Social Studies Research and Practice, 7(2), 1-14. 
Cho, S., \& Reich, G. A. (2008). New immigrants, new challenges: High school social studies teachers and English language learner instruction. Social Studies, 99, 235242.

Choi, Y., Lim, J. H., \& An, S. (2011). Marginalized students' uneasy learning: Korean immigrant students' experiences of learning social studies. Social Studies Research \& Practice, 6(3), 1-17.

Coffey, A., \& Atkinson, P. (1996). Making sense of qualitative data: Complementary research strategies. Thousand Oaks, CA: SAGE Publications.

Colley, L. M. (2015). “Taking the stairs” to break the ceiling: Understanding students' conceptions of the intersections of historical agency, gender equity, and action (Doctoral dissertation, University of Kentucky). Retrieved from http://uknowledge.uky.edu/edsc_etds/4/

Colombo, M., \& Fontaine, P. (2009). Building vocabulary and fostering comprehension strategies for English language learners: The power of academic conversations in social studies. New England Reading Association Journal, 45(1), 46-54.

Cornbleth, C., \& Waugh, D. (1999). The great speckled bird: Multicultural politics and education policymaking. Mahwah, NJ: Lawrence Erlbaum.

Counsell, C. (2004). Looking through a Josephine-Butler-shaped window: focusing pupils' thinking on historical significance. Teaching History, 114, 30-36.

Creswell, J. W. (2009). Research design: Qualitative, quantitative, and mixed methods approaches (3rd ed.). Thousand Oaks, CA: SAGE Publications.

Crocco, M. S. (2001). The missing discourse about gender and sexuality in the social studies. Theory Into Practice, 40(1), 65-71. doi: 10.1207/s15430421tip4001_10 
Crocco, M. S. (2007). Speaking truth to power: Women's rights as human rights. The Social Studies, 98(6), 257-269. doi: 10.3200/tsss.98.6.257-269

Crocco, M. S. (2008). Gender and sexuality in the social studies. In L. S. Levstik \& C. A. Tyson (Eds.), Handbook of research in social studies education (pp. 172-196). New York, NY: Routledge.

Cruz, B. C., \& Thornton, S. J. (2009a). Social studies for English language learners: Teaching social studies that matters. Social Education, 73, 271-274.

Cruz, B. C., \& Thornton, S. J. (2009b). Teaching social studies to English language learners. New York, NY: Routledge.

Dabach, D. B. (2014). "You can't vote, right?": When language proficiency is a proxy for citizenship in a civics classroom. Journal of International Social Studies, 4(2), 3756.

Dan, Y., Todd, R., \& Lan, W. (2010). Consensus and difference: American students' perspectives on the national history. Education, 131(2), 331-341.

Darling-Hammond, L., French, J., \& Garcia-Lopez, S. P. (Eds.). (2002). Learning to teach for social justice. New York, NY: Teachers College Press.

Dawson, I. (2003). What is history: Year 7: Pupils book. London, England: Hodder Education.

de Oliveira, L. C. (2011). Knowing and writing school history: The language of students' expository writing and teachers' expectations. Charlotte, NC: Information Age Publishing. 
DiCerbo, P. A., Anstrom, K. A., Baker, L. L., \& Rivera, C. (2014). A review of the literature on teaching academic English to English language learners. Review of Educational Research. doi: 10.3102/0034654314532695

Duong, M. T., Badaly, D., Liu, F. F., Schwartz, D., \& McCarty, C. A. (2015).

Generational differences in academic achievement among immigrant youths: A meta-analytic review. Review of Educational Research. doi:

$10.3102 / 0034654315577680$

Emerson, R. M., Fretz, R. I., \& Shaw, L. L. (1995). Writing ethnographic fieldnotes. Chicago, IL: The University of Chicago Press.

Enright, K. A. (2011). Language and literacy for a new mainstream. American Educational Research Journal, 48(1), 80-118. doi: 10.3102/0002831210368989

Epstein, T. L. (1998). Deconstructing differences in African-American and EuropeanAmerican adolescents' perspectives on U.S. history. Curriculum Inquiry, 28, 397423.

Epstein, T. L. (2000). Adolescents' perspectives on racial diversity in U.S. history: Case studies from an urban classroom. American Educational Research Journal, 37, $185-214$.

Epstein, T. L. (2001). Racial identity and young people's perspectives on social education. Theory Into Practice, 40(1), 42-47.

Epstein, T. L. (2009). Interpreting national history: Race, identity, and pedagogy in classroom and communities. New York, NY: Routledge. 
Epstein, T. L., Mayorga, E., \& Nelson, J. (2011). Teaching about race in an urban history class: The effects of culturally responsive teaching. Journal of Social Studies Research, 35(1), 2-21.

Erickson, F. (1986). Qualitative methods in research on teaching. In M. C. Wittrock (Ed.), Handbook of research on teaching (3rd ed., pp. 119-161). New York, NY: Macmillan.

Erickson, F., \& Schultz, J. (1992). Students' experience of the curriculum. In P. W. Jackson (Ed.), Handbook of research on curriculum (pp. 465-485). New York, NY: Macmillan.

Erikson, E. H. (1959). Identity and the life cycle. Psychological Issues, 1(1), 1-171.

Erikson, E. H. (1968). Identity: Youth and crisis. New York, NY: W. W. Norton \& Company.

Esteban-Guitart, M., \& Moll, L. C. (2014). Funds of identity: A new concept based on the funds of knowledge approach. Culture \& Psychology, 20(1), 31-48. doi: $10.1177 / 1354067 X 13515934$

Evans, R. W. (2004). The social studies wars: What should we teach the children? New York, NY: Teacher College Press.

Flores, N. (2013). Silencing the subaltern: Nation-state/colonial governmentality and bilingual education in the United States. Critical Inquiry in Language Studies, 10(4), 263-287. doi: 10.1080/15427587.2013.846210

Flyvbjerg, B. (2001). Making social science matter: Why social inquiry fails and how it can succeed again. New York, NY: Cambridge University Press. 
Franquiz, M. E., \& Salinas, C. S. (2011). Newcomers to the U.S.: Developing historical thinking among Latino immigrant students in a central Texas high school. Bilingual Research Journal, 34(1), 58-75. doi: 10.1080/15235882.2011.568831

Fritzen, A. (2011). Teaching as sheltering: A metaphorical analysis of sheltered instruction of English language learners. Curriculum Inquiry, 41, 185-211. doi: 10.1111/j.1467-873X.2011.00578.X

Gallucci, S. (2014). Negotiating second-language identities in and through border crossing. Compare: A Journal of Comparative and International Education, 44, 916-937. doi: 10.1080/03057925.2013.835207

García, O. (2009). Education, multilingualism and translanguaging in the 21 st century. In T. Skutnabb-Kangas, R. Phillipson, A. K. Mohanty \& M. Panda (Eds.), Social justice through multilingual education (pp. 140-158). Buffalo, NY: Multilingual Matters.

García, O. (2010). Latino language practices and literacy education in the U.S. In M. Farr, L. Seloni \& J. Song (Eds.), Ethnolinguistic diversity and education: Language, literacy, and culture (pp. 193-211). New York, NY: Routledge.

García, O., Kleifgen, J., \& Falchi, L. (2008). From English language learners to emergent bilinguals: A research initiative of the Campaign for Educational Equity. New York, NY: Teachers College Press.

García, O., Woodley, H. H., Flores, N., \& Chu, H. (2013). Latino emergent bilingual youth in high schools: Transcaring strategies for academic success. Urban Education, 48, 798-827. doi: 10.1177/0042085912462708 
Gavrilos, D. (2010). Becoming "100\% American": Negotiating ethnic identities through nativist discourse. Critical Discourse Studies, 7(2), 95-112. doi: $10.1080 / 17405901003675398$

Gay, G. (2000). Culturally response teaching: Theory, research, and practice. New York, NY: Teachers College Press.

Goldberg, T. (2013). "It's in my veins": Identity and disciplinary practice in students' discussions of a historical issue. Theory and Research in Social Education, 41(1), 33-64. doi: 10.1080/00933104.2012.757265

González, C., \& Gándara, P. (2005). Why we like to call ourselves Latinas. Journal of Hispanic Higher Education, 4, 392-398. doi: 10.1177/1538192705279407

Gottlieb, E., \& Wineburg, S. (2012). Between "veritas" and "communitas": Epistemic switching in the reading of academic and sacred history. Journal of the Learning Sciences, 21(1), 84-129. doi: 10.1080/10508406.2011.582376

Grant, S. G. (2003). History lessons: Teaching, learning and testing in U.S. high school classrooms. Mahweh, NJ: Lawrence Erlbaum Publishers.

Grant, S. G. (2010). High-stakes testing: How are social studies teachers responding? In W. C. Parker (Ed.), Social studies today: Research \& practice (pp. 43-52). New York, NY: Routledge.

Grant, S. G., \& Gradwell, J. M. (Eds.). (2010). Teaching history with big ideas: Cases of ambitious teachers. Lanham, MD: Rowman \& Littlefield Education.

Grant, S. G., \& Salinas, C. (2008). Assessment and accountability in the social studies. In L. S. Levstik \& C. A. Tyson (Eds.), Handbook of research in social studies education (pp. 219-236). New York, NY: Routledge. 
Guba, E. G., \& Lincoln, Y. S. (1994). Competing paradigms in qualitative research. In N. K. Denzin \& Y. S. Lincoln (Eds.), The handbook of qualitative research (pp. 105117). Thousand Oaks, CA: Sage.

Gutiérrez, K. D., \& Orellana, M. F. (2006). The “problem” of English learners: Constructing genres of difference. Research in the Teaching of English, 40, 502507.

Gutierrez, K. D., \& Rogoff, B. (2003). Cultural ways of learning: Individual traits or repertoires of practice. Educational Researcher, 32(5), 19-25.

Hahn, C. L., Bernard-Powers, J., Crocco, M., \& Woyshner, C. (2007). Gender equity and social studies. In S. S. Klein (Ed.), Handbook for achieving gender equity through education (2nd ed., pp. 335-359). Mahwah, NJ: Lawrence Erlbaum Associates.

Harris, L. M., Halvorsen, A.-L. F., \& Aponte-Martinez, G. J. (2015, April). Does students' heritage matter in their performance on and perceptions of historical reasoning tasks? Paper presented at the meeting of the American Educational Research Association (AERA), Chicago, IL.

Hawkins, M. R. (2004). Researching English language and literacy development in schools. Educational Researcher, 33(3), 14-25. doi:

10.3102/0013189X033003014

Herczog, M. (2013). Q and A about the college, career, and civic life (C3) framework for social studies state standards. Social Education, 77, 218-219.

Hess, D. E., \& McAvoy, P. (2015). The political classroom: Evidence and ethics in democratic education. New York, NY: Routledge. 
Hilburn, J. (2014). Challenges facing immigrant students beyond the linguistic domain in a new gateway state. Urban Review, 46, 654-680. doi: $10.1007 / \mathrm{s} 11256-014-0273-\mathrm{x}$

Hilburn, J., \& Fitchett, P. G. (2012). The new gateway, an old paradox: Immigrants and involuntary Americans in North Carolina history textbooks. Theory \& Research in Social Education, 40(1), 35-65. doi: 10.1080/00933104.2012.647976

Hirvela, A. (2010). Diverse literacy practices among Asian populations: Implications for theory and pedagogy. In M. Farr, L. Seloni \& J. Song (Eds.), Ethnolinguistic diversity and education: Language, literacy, and culture (pp. 99-126). New York, NY: Routledge.

Hood, M. (2009). Case study. In J. Heigham \& R. A. Croker (Eds.), Qualitative research in applied linguistics: A practical introduction (pp. 66-90). New York, NY: Palgrave Macmillan.

Hornsby, M. (2015). Constructing a Lemko identity: Tactics of belonging. International Journal of Multilingualism, 12(1), 1-12. doi: 10.1080/14790718.2014.944185

Hundt, M. (2014). Home is where you're born: Negotiating identity in the diaspora. Studia Neophilologica, 86(2), 125-137. doi: 10.1080/00393274.2014.959292

Irizarry, J. G. (2007). Ethnic and urban intersections in the classroom: Latino students, hybrid identities, and culturally responsive pedagogy. Multicultural Perspectives, 9(3), 21-28. doi: 10.1080/15210960701443599

Jaffee, A. T. (2016). Community, voice, and inquiry: Teaching global history for English language learners. The Social Studies, 107(3), 1-13. doi:

$10.1080 / 00377996.2016 .1140626$ 
James, J. H. (2010). "Democracy is the devil's snare": Theological certainty in teacher education. Theory \& Research in Social Education, 38, 618-639. doi: $10.1080 / 00933104.2010 .10473441$

Janzen, J. (2008). Teaching English language learners in the content areas. Review of Educational Research, 78, 1010-1038. doi: 10.3102/0034654308325580

Jimenez-Silva, M., Hinde, E., \& Hernandez, N. J. (2013). How are teachers of social studies addressing the needs of English language learners in their classrooms? In J. Passe \& P. G. Fitchett (Eds.), The status of social studies: Views from the field (pp. 275-286). Charlotte, NC: Information Age Publishing.

Johnson, K. E. (2006). The sociocultural turn and its challenges for second language teacher education. TESOL Quarterly, 40, 235-257. doi: 10.2307/40264518

Journell, W. (2008). When oppression and liberation are the only choices: The representation of African Americans within state social studies standards. Journal of Social Studies Research, 32, 40-50.

Journell, W. (2009). Setting out the (un) welcome mat: A portrayal of immigration in state standards for American history. The Social Studies, 100(4), 160-168. doi: 10.3200/tsss.100.4.160-168

Justice, B., \& Stanley, J. (2016). Teaching in the time of Trump. Social Education, 80(1), $36-41$.

Kapp, R., \& Bangeni, B. (2011). A longitudinal study of students' negotiation of language, literacy and identity. Southern African Linguistics and Applied Language Studies, 29, 197-208. doi: 10.2989/16073614.2011.633366 
Kena, G., Aud, S., Johnson, F., Wang, X., Zhang, J., Rathbun, A., et al. (2014). The condition of education 2014. (NCES 2014-083). Washington, DC: U.S. Department of Education, National Center for Education Statistics. Retrieved from http://nces.ed.gov/pubs2014/2014083.pdf.

Kibler, A. (2008). Speaking like a "Good American": National identity and the legacy of German-language education. The Teachers College Record, 110, 1241-1268.

Kibler, A., Futch, V. A., Elreda, L., Bergey, R., Karam, F. J., \& Yoder, P. J. (2015, April). English learners' classroom peer networks: Mixed-methods insights into English language development. Paper presented at the meeting of the American Educational Research Association (AERA), Chicago, IL.

Kibler, A., \& Valdés, G. (2016). Conceptualizing language learners: Socio-institutional mechanisms and their consequences. Modern Language Journal, 100, 96-116. doi: $10.1111 / \bmod 1.12310$

Kibler, A., Valdés, G., \& Walqui, A. (2014). What does standards-based educational reform mean for English language learner populations in primary and secondary schools? TESOL Quarterly, 48, 433-453. doi: 10.1002/tesq.183

Kohlmeier, J., \& Saye, J. W. (2015). Ethical reasoning of U.S. high school seniors exploring just versus unjust laws. Theory \& Research in Social Education, 42, 548-578. doi: 10.1080/00933104.2014.966218

Krefting, L. (1999). Rigor in qualitative research: The assessment of trustworthiness. In A. K. Milinki (Ed.), Cases in qualitative research: Research reports for discussion and evaluation (pp. 173-181). Los Angeles, CA: Pyrczak.

Kvale, S. (2007). Doing interviews. Thousand Oaks, CA: Sage. 
Lantolf, J. P. (2011). The sociocultural approach to second language acquisition: Sociocultural theory, second language acquisition, and artificial L2 development. In D. Atkinson (Ed.), Alternative approaches to second language acquisition (pp. 24-47). New York, NY: Routledge.

Lantolf, J. P., \& Thorne, S. L. (2006). Sociocultural theory and the genesis of second language development. New York, NY: Oxford University Press.

Lee, O., Quinn, H., \& Valdés, G. (2013). Science and language for English language learners in relation to Next Generation Science Standards and with implications for Common Core State Standards for English language arts and mathematics. Educational Researcher, 42, 223-233.

Lee, P. (2005). Putting principles into practice: Understanding history. In M. S. Donovan \& J. D. Bransford (Eds.), How students learn: History in the classroom (pp. 3177). Washington, DC: The National Academies Press.

Lee, P. (2012). Series introduction. In M. Carretero, M. Asensio \& M. Rodríguez-Moneo (Eds.), History education and the construction of national identities (pp. ix-xvi). Charlotte, NC: Information Age.

Leung, C., Harris, R., \& Rampton, B. (1997). The idealised native speaker, reified ethnicities, and classroom realities. TESOL Quarterly, 31(3). doi: $10.2307 / 3587837$

Lévesque, S. (2008). Thinking historically: Education students for the twenty-first century. Toronto, Canada: University of Toronto Press. 
Levstik, L. S. (2008). What happens in social studies classrooms? Research on K-12 social studies practice. In L. S. Levstik \& C. A. Tyson (Eds.), Handbook of research in social studies education (pp. 50-62). New York, NY: Routledge.

Levstik, L. S., \& Barton, K. C. (2008). Researching history education: Theory, method and context. New York, NY: Routledge.

Levstik, L. S., \& Groth, J. (2002). "Scary thing, being an eighth grader”: Exploring gender and sexuality in a middle school U.S. history unit. Theory \& Research in Social Education, 30(2), 233-254. doi: 10.1080/00933104.2002.10473193

Levstik, L. S., \& Tyson, C. A. (2008). Introduction. In L. S. Levstik \& C. A. Tyson (Eds.), Handbook of research in social studies education (pp. 1-12). New York, NY: Routledge.

Levy, S. A. (2014). Heritage, history, and identity. Teachers College Record, 116(6), 134.

Loewen, J. W. (1995). Lies my teacher told me: Everything your American history textbook got wrong. New York, NY: Touchstone.

Loewen, J. W. (2010). Teaching what really happened: How to avoid the tyranny of textbooks and get students excited about doing history. New York, NY: Teachers College Press.

Lucas, T., \& Villegas, A. M. (2010). The missing piece in teacher education: The preparation of linguistically responsive teachers. National Society for the Study of Education Yearbook, 109, 297-318.

Lucas, T., Villegas, A. M., \& Freedson-Gonzalez, M. (2008). Linguistically responsive teacher education: Preparing classroom teachers to teach English language 
learners. Journal of Teacher Education, 59, 361-373. doi:

$10.1177 / 0022487108322110$

Lucas, T., Villegas, A. M., \& Martin, A. D. (2015). Teachers' beliefs about English language learners. In H. Fives \& M. G. Gill (Eds.), International handbook of research on teachers' beliefs (pp. 453-474). New York, NY: Routledge.

Macías, R. F. (2014). Spanish as the second national language of the United States: Fact, future, fiction, or hope? Review of Research in Education, 38(1), 33-57. doi: $10.3102 / 0091732 \times 13506544$

Mangual Figueroa, A. (2012). "I have papers so I can go anywhere!": Everyday talk about citizenship in a mixed-status Mexican family. Journal of Language, Identity \& Education, 11, 291-311. doi: 10.1080/15348458.2012.722894

Manke, M. P., \& Keller, K. (2006). Lao newcomers and Mennonite settlers: A case study of local cultural and language interaction. Journal of Language, Identity \& Education, 5(2), 123-141. doi: 10.1207/s15327701jlie0502_2

Marshall, C., \& Rossman, G. B. (2011). Designing qualitative research (5th ed.). Thousand Oaks, CA: SAGE.

Martell, C. C. (2013). Race and histories: Examining culturally relevant teaching in the U.S. history classroom. Theory and Research in Social Education, 41(1), 65-88. doi: $10.1080 / 00933104.2013 .755745$

Martínez, R. A. (2010). "Spanglish" as literacy tool: Toward an understanding of the potential role of Spanish-English code-switching in the development of academic literacy. Research in the Teaching of English, 45(2), 124-149. doi:

$10.2307 / 40997087$ 
McKay, S. L., \& Wong, S.-L. C. (1996). Multiple discourses, multiple identities:

Investment and agency in second-language learning among Chinese adolescent immigrant students. Harvard Educational Review, 66, 577-608.

Monzó, L. D., \& Rueda, R. (2009). Passing for English fluent: Latino immigrant children masking language proficiency. Anthropology \& Education Quarterly, 40(1), 2040. doi: $10.1111 / \mathrm{j} .1548-1492.2009 .01026 . x$

Nash, G. B., Crabtree, C., \& Dunn, R. E. (2000). History on trial: Culture wars and the teaching of the past. New York, NY: Vintage Books.

National Clearinghouse for English Language Acquisition. (2011). The growing numbers of English learner students 2009/10. Retrieved from http://www.ncela.us/files/uploads/9/growing_EL_0910.pdf

National Council for the Social Studies. (2013). The college, career, and civic life (C3) framework for social studies state standards: Guidance for enhancing the rigor of K-12 civics, economics, geography, and history. Silver Spring, MD: NCSS.

Nieto, S. (1999). The light in their eyes: Creating multicultural learning environments. New York, NY: Teachers College Press.

Nieto, S. (2000). Affirming diversity: The sociopolitical context of multicultural education (3rd ed.). New York, NY: Addison Wesley Longman.

Nieto, S. (2013). Finding joy in teaching students of diverse backgrounds: Culturally responsive and socially just practices in U.S. classrooms. Portsmouth, NH: Heinemann.

Norton, B. (2000). Identity and language learning: Gender, ethnicity and educational change. Harlow, England: Longman/Pearson Education. 
Norton, B. (2010). Identity, literacy, and English-language teaching. TESL Canada Journal, 28(1), 1-13.

Norton, B. (2013). Identity and language learning: Extending the conversation (2nd ed.). Buffalo, NY: Multilingual Matters.

Norton, B., \& Early, M. (2011). Researcher identity, narrative inquiry, and language teaching research. TESOL Quarterly, 45(3), 415-439. doi: $10.5054 /$ tq. 2011.261161

Norton, B., \& McKinney, C. (2011). An identity approach to second language acquisition. In D. Atkinson (Ed.), Alternative approaches to second language acquisition (pp. 73-94). New York, NY: Routledge.

Norton Peirce, B. (1995). Social identity, investment, and language learning. TESOL Quarterly, 29(1), 9-31. doi: 10.2307/3587803

O’Brien, J. (2009). High school social studies teachers' attitudes toward English language learners. Social Studies Research and Practice, 4, 36-48.

O’Brien, J. (2011). The system is broken and it's failing these kids: High school social studies teachers' attitudes towards training for ELLs. Journal of Social Studies Research, 35, 22-38.

O’Brien, J. (2012). English language learners (ELLs) and social studies. In W. B. Russell III (Ed.), Contemporary social studies: An essential reader (pp. 293-315). Charlotte, NC: Information Age.

O’Neill, F. (2013). Making sense of being between languages and cultures: A performance narrative inquiry approach. Language and Intercultural Communication, 13, 386-399. doi: 10.1080/14708477.2012.758733 
O’Rourke, B. (2005). Expressing identity through lesser-used languages: Examples from the Irish and Galician contexts. Language and Intercultural Communication, 5, 274-283. doi: 10.1080/14708470508668901

Office of English Language Acquisition. (2015a). English learners (ELs) and college and career readiness. Washington, DC: Department of Education. Retrieved from http://staging.ncela.seiservices.com/files/fast_facts/OELA_FastFacts_ELsandCR DC_CollegeReadiness.pdf.

Office of English Language Acquisition. (2015b). English learners (ELs) and NAEP. Washington, DC: Department of Education. Retrieved from http://staging.ncela.seiservices.com/files/fast_facts/OELA_FastFacts_ELsandNA EP.pdf.

Office of English Language Acquisition. (2015c). Profiles of English learners (ELs). Washington, DC: Department of Education. Retrieved from http://staging.ncela.seiservices.com/files/fast_facts/OELA_FastFacts_ProfilesOfE Ls.pdf.

Office of English Language Acquisition. (2015d). Retention and suspension of English learners (ELs). Washington, DC: Department of Education. Retrieved from http://staging.ncela.seiservices.com/files/fast_facts/OELA_FastFacts_ELsandCR DC_RetentionandSuspension.pdf.

Olsen, L. (1997). Made in America: Immigrant students in our public schools. New York, NY: The New Press. 
Orellana, M. F., \& Gutiérrez, K. D. (2006). What's the problem? Constructing different genres for the study of English learners. Research in the Teaching of English, $41(1), 118-123$.

Ortega, L. (2011). SLA after the social turn: Where cognitivism and its alternatives stand. In D. Atkinson (Ed.), Alternative approaches to second language acquisition (pp. 167-180). New York, NY: Routledge.

Ortega, L. (2013). Understanding second language acquisition. New York, NY: Routledge.

Palmer, D., \& Martínez, R. A. (2013). Teacher agency in bilingual spaces: A fresh look at preparing teachers to educate Latina/o bilingual children. Reviews of Research in Education, 37, 269-297. doi: 10.3102/0091732X12463556

Parker, W. C. (2008). Knowing and doing in democratic citizenship education. In L. S. Levstik \& C. A. Tyson (Eds.), Handbook of research in social studies education (pp. 65-80). New York, NY: Routledge.

Parker, W. C. (2010). Idiocy, puberty, and citizenship. In W. C. Parker (Ed.), Social studies today: Research \& practice (pp. 247-260). New York, NY: Routledge.

Parmegiani, A. (2014). The (dis)ownership of English: Language and identity construction among Zulu students at the University of KwaZulu-Natal. International Journal of Bilingual Education and Bilingualism, 17, 683-694. doi: $10.1080 / 13670050.2014 .953775$

Patton, M. Q. (2002). Qualitative research and evaluative methods (3rd ed.). Thousand Oaks, CA: Sage. 
Peck, C. L. (2010). "It's not like [I'm] Chinese and Canadian. I am in between": Ethnicity and students' conceptions of historical significance. Theory \& Research in Social Education, 38, 574-617.

Peck, C. L., \& Herriot, L. (2015). Teachers' beliefs about social studies. In H. Fives \& M. G. Gill (Eds.), International handbook of research on teachers' beliefs (pp. 387402). New York, NY: Routledge.

Phinney, J. S. (1992). The Multigroup Ethnic Identity Measure: A new scale for use with diverse groups. Journal of Adolescent Research, 7(2), 156-176. doi: $10.1177 / 074355489272003$

Porat, D. A. (2004). "It's not written here, but this is what happened": Students' cultural comprehension of textbook narratives on the Israeli-Arab conflict. American Educational Research Journal, 41, 963-996. doi: 10.3102/00028312041004963

Powers, J. M. (2014). From segregation to school finance: The legal context for language rights in the United States. Review of Research in Education, 38(1), 81-105. doi: $10.3102 / 0091732 \times 13506550$

Quirk, R. (2000). Language and identity. English Academy Review, 17(1), 2-11. doi: $10.1080 / 10131750085310031$

Ramirez, A. D. (2012). Latino cultural knowledge in the social studies classroom. Journal of Hispanic Higher Education, 11, 213-226. doi: $10.1177 / 1538192711436084$

Reisman, A., \& Wineburg, S. (2008). Teaching the skill of contextualizing in history. The Social Studies 99, 202-207. doi: 10.3200/TSSS.99.5.202-207 
Ruiz, R. (1984). Orientations in language planning. Journal for the National Association for Bilingual Education, 8(2), 15-34.

Salinas, C., \& Blevins, B. (2014). Critical historical thinking: How might pre-service teachers confront master historical narratives? . Social Studies Research and Practice, 9(3), 35-50.

Salinas, C., Blevins, B., \& Sullivan, C. (2012). Critical historical thinking: When official narratives collide with other narratives. Multicultural Perspectives, 14(1), 18-27.

Santiago, M. (2013). Teaching a new chapter of history. Phi Delta Kappan, 94(6), 35-38. doi: $10.1177 / 003172171309400609$

Schleppegrell, M. J. (2004). The language of schooling: A functional linguistics perspective. New York, NY: Routledge.

Schleppegrell, M. J., Achugar, M., \& Oteiza, T. (2004). The grammar of history: Enhancing content-based instruction through a functional focus on language. TESOL Quarterly, 38, 67-93. doi: 10.2307/3588259

Schleppegrell, M. J., \& de Oliveira, L. C. (2006). An integrated language and content approach for history teachers. Journal of English for Academic Purposes, 5, 254268. doi: $10.1016 /$ j.jeap.2006.08.003

Schleppegrell, M. J., Greer, S., \& Taylor, S. (2008). Literacy in history: Language and meaning. Australian Journal of Language \& Literacy, 31, 174-187.

Schmeichel, M. (2015). Skirting around critical feminist rationales for teaching women in social studies. Theory \& Research in Social Education, 43(1), 1-27. doi: $10.1080 / 00933104.2014 .1002648$ 
Schocker, J. B., \& Woyshner, C. (2013). Representing African American women in U.S. history textbooks. The Social Studies, 104(1), 23-31. doi:

$10.1080 / 00377996.2012 .655346$

Schwartz-Shea, P., \& Yanow, D. (2012). Interpretive research design: Concepts and processes. New York, NY: Routledge.

Schwebel, S. L. (2011). Child-sized history: Fictions of the past in U.S. classrooms. Nashville, TN: Vanderbilt University Press.

Schweber, S. (2006a). "Breaking down barriers" or "Building strong Christians": Two treatments of Holocaust history. Theory \& Research in Social Education, 34(1), 9-33. doi: 10.1080/00933104.2006.10473296

Schweber, S. (2006b). Fundamentally 9/11: The fashioning of collective memory in a Christian school. American Journal of Education, 112, 392-417. doi: $10.1086 / 500714$

Schweber, S. (2010). Holocaust fatigue in teaching today. In W. C. Parker (Ed.), Social studies today: Research \& practice (pp. 151-162). New York, NY: Routledge.

Schweber, S., \& Irwin, R. (2003). "Especially special”: Learning about Jews in a fundamentalist Christian school. Teachers College Record, 105, 1693-1719.

Seixas, P. (2009). National history and beyond. Journal of Curriculum Studies, 41, 719722. doi: $10.1080 / 00220270903045253$

Seixas, P., \& Morton, T. (2013). The big six historical thinking concepts. Scarborough, Ontario: Nelson Education.

Shear, S. B., Knowles, R. T., Soden, G. J., \& Castro, A. J. (2015). Manifesting destiny: Re/presentations of indigenous peoples in K-12 U.S. history standards. Theory \& 
Research in Social Education, 43(1), 68-101. doi:

$10.1080 / 00933104.2014 .999849$

Short, D. J. (2002). Language learning in sheltered social studies classes. TESOL Journal, 11(1), 18-24. doi: 10.1002/j.1949-3533.2002.tb00062.x

Silverman, D. (2005). Doing qualitative research (2nd ed.). Thousand Oaks, CA.

Siziba, G. (2014). Language and identity negotiations: An analysis of the experiences of Zimbabwean migrants in Johannesburg, South Africa. Journal of African Cultural Studies, 26(2), 173-188. doi: 10.1080/13696815.2013.860517

Sleeter, C. E. (1996). Multicultural education as social activism. Albany, NY: State University of New York Press.

Spector, K. (2007). God on the gallows: Reading the Holocaust through narratives of redemption. Research in the Teaching of English, 42(1), 7-55. doi: $10.2307 / 40171747$

Suárez-Orozco, C., Gaytan, F. X., Bang, H. J., Pakes, J., O’Connor, E., \& Rhodes, J. (2010). Academic trajectories of newcomer immigrant youth. Developmental Psychology, 46, 602-618. doi: 10.1037/a0018201

Suárez-Orozco, C., Suárez-Orozco, M. M., \& Todorova, I. (2008). Learning a new land: Immigrant students in American society. Cambridge, MA: The Belknap Press of Harvard University Press.

Suh, Y., An, S., \& Forest, D. (2015). Immigration, imagined communities, and collective memories of Asian American experiences: A content analysis of Asian American experiences in Virginia U.S. history textbooks. The Journal of Social Studies Research, 39(1), 39-51. doi: 10.1016/j.jssr.2014.05.002 
Swan, K., \& Griffin, S. (2013). Beating the odds: The college, career, and civic life (C3) framework for social studies state standards. Social Education, 77, 317-321.

Talmy, S. (2010). Becoming "local" in ESL: Racism as resource in a Hawai'i public high school. Journal of Language, Identity \& Education, 9(1), 36-51. doi: $10.1080 / 15348450903476840$

Tatum, B. D. (2003). "Why are all the black kids sitting together in the cafeteria?": And other conversations about race. New York, NY: Basic Books.

Teddlie, C., \& Tashakkori, A. (2009). Foundations of mixed methods research. Thousand Oaks, CA: Sage

Terzian, S. G., \& Yeager, E. A. (2007). “That's when we became a nation” :Urban Latino adolescents and the designation of historical significance. Urban Education, 42(1), 52-81. doi: 10.1177/0042085906294027

The Board of Regents of the University of Wisconsin System. (2014). World-class instructional design and assessment. Retrieved from http://www.wida.us/index.aspx

Thieman, G. Y., O’Brien, J. E., Preston-Grimes, P., Broome, J. P., \& Barker, T. W. (2013). From the field: What social studies teachers in three states report they do in the classroom. In J. Passe \& P. G. Fitchett (Eds.), The status of social studies: Views from the field (pp. 41-62). Charlotte, NC: Information Age.

Turkan, S., \& DaSilva Iddings, A. C. (2012). That child is a yellow: New immigrant children's conceptions of English language, literacy, and learners' identities in the NCLB era. Theory Into Practice, 51, 273-280. doi:

$10.1080 / 00405841.2012 .726055$ 
Twyman, T., Ketterlin-Geller, L. R., McCoy, J. D., \& Tindal, G. (2003). Effects of concept-based instruction on an English language learner in a rural school: A descriptive case study. Bilingual Research Journal, 27, 259-274.

Umaña-Taylor, A. J. (2009). Research with Latino early adolescents: Strengths, challenges and directions for future research. Journal of Early Adolescence, 29(1), 5-15. doi: 10.1177/0272431608324481

Valdés, G. (1996). Con respeto: Bridging the distances between culturally diverse families and schools: An ethnographic portrait. New York, NY: Teachers College Press.

Valdés, G. (2015). Latin@s and the intergenerational continuity of Spanish: The challenges of curricularizing language. International Multilingual Research Journal, 9, 253-273. doi: 10.1080/19313152.2015.1086625

Valdés, G. (2016, April). English language learners, linguistically multi-competent students, or emerging bilinguals? Labels, categories and generative metaphors. Paper presented at the meeting of the American Educational Research Association, Washington, D.C.

Valdés, G., Kibler, A., \& Walqui, A. (2014). Changes in the expertise of ESL professionals: Knowledge and action in an era of new standards. Alexandria, VA: TESOL International Association.

Valenzuela, A. (1999). Subtractive schooling: U.S.-Mexican youth and the politics of caring. Albany, NY: State University of New York Press.

Van Alphen, F., \& Asensio, M. (2012). Commentary: The complex construction of identity representations and the future of history education. In M. Carretero, M. 
Asensio \& M. Rodríguez-Moneo (Eds.), History education and the construction of national identities (pp. 347-359). Charlotte, NC: Information Age.

van Hover, S. (2006). Teaching history in the Old Dominion. In S. G. Grant (Ed.), Measuring history: Cases of state-level testing across the United States (pp. 195219). Charlotte, NC: Information Age Publishing.

van Hover, S., Hicks, D., Stoddard, J., \& Lisanti, M. (2010). From a roar to a murmur: Virginia's history \& social science standards, 1995-2009. Theory \& Research in Social Education, 38(1), 80-113. doi: 10.1080/00933104.2010.10473417 van Hover, S., \& Yeager, E. (2007). "I want to use my subject matter to...”: The role of purpose in one U.S. secondary history teacher's instructional decision making. Canadian Journal of Education, 30, 670-690. doi: 10.2307/20466658

VanSledright, B. A. (2002). In search of America's past: Learning to read history in elementary school. New York, NY: Teachers College Press.

VanSledright, B. A. (2008). Narratives of nation-state, historical knowledge, and school history education. Review of Research in Education, 32, 109-146. doi: $10.2307 / 20185114$

Vansledright, B. A. (2010a). The challenge of rethinking history education: On practices, theories, and policy. New York, NY: Routledge.

Vansledright, B. A. (2010b). What does it mean to think historically... and how do you teach it? In W. C. Parker (Ed.), Social studies today: Research \& practice (pp. 113-120). New York, NY: Routledge.

VanSledright, B. A. (2014). Assessing historical thinking and understanding: Innovative designs for new standards. New York, NY: Routledge. 
VanSledright, B. A., Kelly, T., \& Meuwissen, K. (2006). Oh, the trouble we've seen: Researching historical thinking and understanding. In K. C. Barton (Ed.), Research methods in social studies education: Contemporary issues and perspectives. Greenwich, CT: Information Age Publishing.

Vasquez Heilig, J., Brown, K. D., \& Brown, A. L. (2012). The illusion of inclusion: A critical race theory textual analysis of race and standards. Harvard Educational Review, 82, 403-424.

Vaughn, S., Martinez, L. R., Linan-Thompson, S., Reutebuch, C. K., Carlson, C. D., \& Francis, D. J. (2009). Enhancing social studies vocabulary and comprehension for seventh-grade English language learners: Findings from two experimental studies. Journal of Research on Educational Effectiveness, 2, 297-324. doi: $10.1080 / 19345740903167018$

Velasco, P., \& García, O. (2014). Translanguaging and the writing of bilingual learners. Bilingual Research Journal, 37(1), 6-23. doi: 10.1080/15235882.2014.893270

Virginia Department of Education. (2008a). History and social science standards of learning: Curriculum Framework 2008: Grade one: Introduction to history and social science. Richmond, VA: Virginia Department of Education. Retrieved from http://www.doe.virginia.gov/testing/sol/frameworks/history_socialscience_frame wks/2008/2008_final/framewks_history1.pdf.

Virginia Department of Education. (2008b). History and social science standards of learning: Curriculum Framework 2008: Kindergarten: Introduction to history and social science. Richmond, VA: Virginia Department of Education. Retrieved 
from

http://www.doe.virginia.gov/testing/sol/frameworks/history_socialscience_frame wks/2008/2008_final/framewks_historyk.pdf.

Virginia Department of Education. (2008c). History and social science standards of learning: Curriculum Framework 2008: United States history: 1865 to the present. Richmond, VA: Virginia Department of Education. Retrieved from http://www.doe.virginia.gov/testing/sol/standards_docs/history_socialscience/.

Wertsch, J. V. (1991). Voices of the mind: A sociocultural approach to mediated action. Cambridge, MA: Harvard University Press.

Wertsch, J. V. (2000). Is it possible to teach beliefs, as well as knowledge about history? In P. N. Stearns, P. Seixas \& S. Wineburg (Eds.), Knowing, teaching, and learning history: National and international perspectives (pp. 38-50). New York, NY: New York University Press.

Williams, J. L., Anderson, R. E., Francois, A. G., Hussain, S., \& Tolan, P. H. (2014). Ethnic identity and positive youth development in adolescent males: A culturally integrated approach. Applied Developmental Science, 18(2), 110-122. doi: $10.1080 / 10888691.2014 .894871$

Williamson, D. L., Choi, J., Charchuk, M., Rempel, G. R., Pitre, N., Breitkreuz, R., et al. (2011). Interpreter-facilitated cross-language interviews: A research note. Qualitative Research, 11, 381-394. doi: 10.1177/1468794111404319

Willoughby, L. (2013). Language practices in multilingual communities: Insights from a suburban high school. International Journal of Multilingualism, 10, 441-453. doi: $10.1080 / 14790718.2013 .832125$ 
Wills, J. S. (2011). Misremembering as mediated action: Schematic narrative templates and elementary students' narration of the past. Theory \& Research in Social Education, 39, 115-144.

Wineburg, S. (2000). Making historical sense. In P. N. Stearns, P. Seixas \& S. Wineburg (Eds.), Knowing, teaching, and learning history: National and international perspectives (pp. 306-325). New York, NY: New York University Press.

Wineburg, S. (2001). Historical thinking and other unnatural acts: Charting the future of teaching the past. Philadelphia, PA: Temple University Press.

Wineburg, S., \& Monte-Sano, C. (2008a). "Famous Americans": The changing pantheon of American heroes. The Journal of American History, 94, 1186-1202. doi: $10.2307 / 25095326$

Wineburg, S., \& Monte-Sano, C. (2008b). Who is a famous American? Charting historical memory across the generations. Phi Delta Kappan, 89, 643-648. doi: $10.1177 / 003172170808900907$

Wineburg, S., Mosborg, S., \& Porat, D. (2010). What can Forest Gump tell us about students' historical understanding? In W. C. Parker (Ed.), Social studies today: Research \& practice (pp. 105-111). New York, NY: Routledge.

Woolley, M. E., Kol, K. L., \& Bowen, G. L. (2009). The social context of school success for Latino middle school students: Direct and indirect influences of teachers, family, and friends. The Journal of Early Adolescence, 29(1), 43-70. doi: $10.1177 / 0272431608324478$

Worthy, J., Durán, L., Hikida, M., Pruitt, A., \& Peterson, K. (2013). Spaces for dynamic bilingualism in read-aloud discussions: Developing and strengthening bilingual 
and academic skills. Bilingual Research Journal, 36, 311-328. doi:

$10.1080 / 15235882.2013 .845622$

Wright, S. (2014). The map, the group and language ideology. Journal of World Languages, 1(2), 81-98. doi: 10.1080/21698252.2014.937562

Yeager, E. A., \& van Hover, S. (2006). Virginia vs. Florida: Two beginning history teachers' perceptions of the influence of high-stakes tests on their instructional decision-making. Social Studies Research and Practice, 1, 340-358.

Yoder, P. J. (2013). Structured academic discussion and academic language acquisition of English language learners. Ohio Social Studies Review, 50(2), 39-51.

Yoder, P. J. (2015). Lebanon: A case of history education in a sectarian society. Journal of International Social Studies, 5(1), 140-149.

Yoder, P. J., Kibler, A., \& van Hover, S. (2014, November). Building a framework for history instruction for English language learners. Paper presented at the meeting of the College and University Faculty Assembly of the National Council for the Social Studies, Boston, MA.

Yoder, P. J., Kibler, A., \& van Hover, S. (2016). Instruction for English language learners in the social studies classroom: A meta-synthesis. Social Studies Research and Practice, 11(1), 20-39.

Yoder, P. J., Kibler, A. K., Futch Ehrlich, V. A., \& Molloy Elreda, L. (2015, November). Knowing your students: Examining the impact of a middle school U.S. history teacher's perceptions of English language learners. Paper presented at the meeting of the Graduate Forum of the College and University Faculty Assembly of the National Council for the Social Studies, New Orleans, LA. 
Yoder, P. J., \& van Hover, S. (2015, April). History instruction with English language learners: A case study. Paper presented at the meeting of the American Educational Research Association, Chicago, IL. 


\section{Appendix A}

Participant Interview Schedule

\begin{tabular}{|c|c|c|c|}
\hline Participant & Initial Interview & $\begin{array}{c}\text { Second Teacher } \\
\text { Interview/Student } \\
\text { Focus Group }\end{array}$ & Final Interview \\
\hline Mr. Mitchell & August 24, 2015 & October 23, 2015 & December 17, 2015 \\
\hline Ms. Rogers & August 26, 2015 & October 20, 2015 & December 18, 2015 \\
\hline Gebre & September 9, 2015 & November 24, 2015 & December 8, 2015 \\
\hline Yousuf & September 9, 2015 & November 19, 2015 & December 9, 2015 \\
\hline Aras & September 10, 2015 & November 24, 2015 & December 9, 2015 \\
\hline Isabel & September 10, 2015 & November 19, 2015 & December 10, 2015 \\
\hline Santiago & September 14, 2015 & November 24, 2015 & December 16, 2015 \\
\hline Javier & September 14, 2015 & November 19,2015 & December 16, 2015 \\
\hline Yonas & September 15, 2015 & November 19,2015 & December 8, 2015 \\
\hline Salvador & September 16, 2015 & November 24, 2015 & December 14, 2015 \\
\hline Marisol & September 16, 2015 & n/a & December 18, 2015 \\
\hline Felix & September 17, 2015 & November 24, 2015 & December 15, 2015 \\
\hline Maria & September 17, 2015 & November 19, 2015 & December 14, 2015 \\
\hline
\end{tabular}

Note. Marisol moved and transferred schools on November 4, 2015. As a result she was no longer in Mr. Mitchell's class when the focus group was conducted. I arranged for an English-Spanish interpreter for both of Marisol's interviews. 


\section{Appendix B}

\section{Initial Teacher Interview Protocol}

Thank you for meeting with me today. Do you mind if I record our conversation so I can accurately record your responses? You may skip any question that you prefer not to answer.

Teacher demographics

- Teaching experience

$\bigcirc$ What is your teaching background?

- How long and what have you taught?

$\circ$ What is your experience with teaching ELLs?

- Motivation

What led you to become a teacher?

○ What formative experiences did you have as a student?

- Brief philosophy

$\circ$ What is your goal in teaching? What are your goals for teaching history?

- What is your general approach in planning lessons?

- Content background

- What is your experience with history?

- What did you study in college?

- Do you have a Master's degree?

Student demographics

- Class overview (for each class)

- How many students are in the class?

- What is your general impression of the class?

- Language proficiency of ELLs

- What assessments are used to measure language proficiency?

- What are the scores of the ELLs in this class?

- Seating chart

○ May I see a seating chart to help inform my observations?

- How do you decide where to seat students?

Instructional Approaches

- Standards

- How do the state standards impact your instructional decisions?

- How do you principal and colleagues talk about the standards?

- Resources

○ What resources do you turn to in your planning?

- How would you describe the level of collaboration with colleagues at your school?

- Methods

- What instructional methods do you use most often?

- How do you decide how to teach?

"What should I have asked you that I didn't think to ask?" (Patton, 2002, p.379) 


\section{Second Teacher Interview Protocol}

Thank you for agreeing to meet with me today. Do you mind if I record our conversation again so I can accurately capture your responses? As before, please feel free to skip any question that you prefer not to answer.

The questions I want to ask today build on observations from the past few weeks. I also want to ask about your planning for the upcoming unit on immigration.

Looking back

- Teacher reflections

- What are your reflections on the beginning of the school year?

- How does this group of students differ from your previous experience?

- How is this group of students similar to other years?

- $\quad$ Researcher reflections

- During my observations I have noticed [ellipses indicate elements that will emerge in the course of fieldwork]. How do you decide...?

○ During the unit on Reconstruction, the students... Why did you...?

- During the unit on Jim Crow I noticed that... To what extent have you...?

Immigration Planning

- Goals

- What are your goals as you prepare the immigration unit?

○ What factors influence how you plan?

- Instructional planning

- Could you walk me through the process of planning the immigration unit?

- What materials did you turn to?

- What experiences have you had in the past that inform this process?

- Could I please make (or have) copies of the pictures students will encounter during this unit?

"What should I have asked you that I didn't think to ask?" (Patton, 2002, p.379) 
Final Teacher Interview Protocol

Thank you for agreeing to meet with me again today. Do you mind if I record our conversation again so I can accurately capture your responses? As before, please feel free to skip any question that you prefer not to answer.

The questions I want to ask today build on observations from throughout the course of the semester.

Fieldnote Excerpts

- Example 1: [include excerpt]

○ How does this excerpt illustrate...?

- How do you interpret Student A's response to your question?

$\circ$ Why...?

- Example 2: [include excerpt]

○ How does this excerpt illustrate...?

- How do you interpret Student B's question in the context of their group assignment?

$\circ$ Why...?

Emerging Findings

- Finding 1

$\circ$ How do you...?

- Finding 2

○

- Finding 3

"What should I have asked you that I didn't think to ask?" (Patton, 2002, p. 379)

Thank you so much for your time this semester. I really appreciate how you opened your classroom to me. 


\section{Appendix C}

\section{Initial Student Interview Protocol}

Thank you for agreeing to meet with me today. Do you mind if I record our conversation so I can remember what you tell me? Please feel free to skip any question that you prefer not to answer.

Student Background: Craft a timeline with the student on a horizontally-oriented piece of paper with a horizontal line down the middle. Invite the student to write on the timeline in response to the following questions or write for them if they choose not to write:

- Card Sort

- We will begin with an activity. Please select five to ten cards that "best describe" you or are the "most important" to you. When you have made your choice I will ask you to explain how you chose those cards (see descriptors in table below).

- How would your friends describe you?

- How would your parents describe you?

- How would your teachers describe you?

\begin{tabular}{|c|c|c|c|c|c|}
\hline Group 1 & Group 2 & Group 3 & Group 4 & Group 5 & Group 6 \\
\hline Boy & Activist & American & $\begin{array}{l}\text { African } \\
\text { American }\end{array}$ & $\begin{array}{l}\text { Arabic- } \\
\text { speaker }\end{array}$ & Other: \\
\hline Brother & Actor & Cuban & Asian & Bilingual & \\
\hline Daughter & Artist & Eritrean & Caucasian & $\begin{array}{l}\text { English } \\
\text { Learner }\end{array}$ & \\
\hline Friend & Athlete & Ethiopian & Christian & $\begin{array}{l}\text { English- } \\
\text { speaker }\end{array}$ & \\
\hline Girl & $\begin{array}{l}\text { Comedian / } \\
\text { Class Clown }\end{array}$ & Guatemalan & Jew & $\begin{array}{l}\text { Kurdish- } \\
\text { speaker }\end{array}$ & \\
\hline Sister & Environmentalist & Honduran & Muslim & $\begin{array}{l}\text { Spanish- } \\
\text { speaker }\end{array}$ & \\
\hline Son & Feminist & Immigrant & & $\begin{array}{l}\text { Tigrinya- } \\
\text { speaker }\end{array}$ & \\
\hline Student & Gamer & Iraqi & & & \\
\hline & Musician & Mexican & & & \\
\hline & Reader & Puerto Rican & & & \\
\hline & Writer & Refugee & & & \\
\hline & & Salvadoran & & & \\
\hline
\end{tabular}

Personal Timeline

- Personal background

- How old are you now? [List on far right side of timeline.]

- Where were you born? [List on far left side of timeline.]

- Where is your family from?

- What languages do you speak at home now? 
- $\quad$ Education background

- When did you first start school? [List near left end of timeline.]

- Where did you go to school? What languages did you speak at school?

- How were those schools similar or different from [name of school]?

- Were you ever absent from school for a month or more all at one time?

- When did you move to [name of city]? [List near right end of timeline.]

○ What else would you like to tell me about?

Perspectives on U.S. History

- Class experiences

- What have you learned about so far this year in [teacher's name]'s class?

- What does [teacher's name] do in history class that you like?

- What have you learned in [teacher's name]'s class that surprised you?

- How is [teacher's name]'s class similar or different from other history classes you have had?

- U.S. history (adapted from Epstein, 1998)

○ Who are the three most important people in United States history? Why? Did you learn about them last year in sixth grade?

- What are the three most important events in United States history? Why? Did you learn about them last year in sixth grade?

- Where is the most believable place to go to get information on history? In other words, where do you go or who do you talk to to learn about history? Examples might your teacher, your family, books or TV.

- How is history you learned about at home different from the history you learned about at school? 


\section{Student Focus Group Interview Protocol}

Thank you for agreeing to meet with me today. Do you mind if I record our conversation so I can accurately capture your responses? Please feel free to skip any question that you prefer not to answer. I also wanted to add that since this is a group conversation it is important to remember to be respectful in how we talk to each other and about each other's ideas. I also need for you to keep our conversation confidential. That means that when we finish today you should not talk to other people about what other students said in this room. Are there any questions?

"Picture-Selection Task" (Peck, 2010)

- Preparation

$\circ$ Ahead of time I collected a total of 18 political cartoons and primary source images from the instructional content and resources that the two participant teachers presented during their immigration units.

- I then printed each on a full-page of cardstock. The one-sentence caption or title that I printed underneath the corresponding images can be found on the second page of this protocol.

- Directions

- As a group, you will select 6 of the picture cards from ideas that [teacher's name] talked about during your recent immigration unit.

○ The goal is to identify and order the people, places or events that you decide are most important.

- Please work together during this process. As you are discussing your opinions you may need to explain why you think a certain card is more or less important than another.

- $\quad$ Prompts

○ While students are working, I will respond to procedural questions, but not content-based questions (e.g., "When did people come to Ellis Island?").

○ I will interject only to draw out individual students (e.g., "Andrea, what do you think about that?").

"Picture-Selection Task" Debrief (Peck, 2010)

- Student Explanation

- Ask for students to explain their choices.

○ Ask probing questions (e.g., "Why did you choose to put this card next?") as time allows.

- Debriefing Questions

○ How does your own experience or your family's experience with immigration impact how you made your timeline about immigration?

○ Do you think other people might make similar or different choices? If so, why?

“What should I have asked you that I didn't think to ask?” (Patton, 2002, p. 379) 
Caption or Title for Picture Cards

\begin{tabular}{|c|c|}
\hline $\begin{array}{l}\text { The Yellow Peril: "Chinese } \\
\text { immigration, Exclusion Act" }\end{array}$ & $\begin{array}{c}\text { The Mortar of Assimilation - And The } \\
\text { One Element That Won't Mix: } \\
\text { Citizenship }\end{array}$ \\
\hline $\begin{array}{c}\text { "That's What's The Matter": "As long } \\
\text { as I count the Votes, what are you } \\
\text { going to do about it? Say?" - Boss } \\
\text { Tweed }\end{array}$ & $\begin{array}{c}\text { "Statue of Liberty": Reasons for } \\
\text { immigration: } \\
\text { - Hope for better opportunities } \\
\text { - Desire for religious freedom } \\
\text { - Escape from oppressive } \\
\text { governments } \\
\text { - Desire for adventure }\end{array}$ \\
\hline $\begin{array}{c}\text { "Dropping hides" and "splitting } \\
\text { chucks" } \\
\text { Beef Department, Swift \& Company's } \\
\text { Packing House, Chicago, U.S.A. }\end{array}$ & $\begin{array}{l}\text { Tenements and ghettos - overcrowded, } \\
\text { full of disease, dirty, dangerous }\end{array}$ \\
\hline $\begin{array}{l}\text { "The Only One Barred Out" } \\
\text { "We must draw the line somewhere, } \\
\text { you know" - Enlightened American } \\
\text { Statesman }\end{array}$ & Discrimination against immigrants \\
\hline $\begin{array}{c}\text { Inventions and Inventors - } \\
\text { Thomas Edison - electric lighting and } \\
\text { mechanical uses of electricity }\end{array}$ & $\begin{array}{c}\text { Inventions and Inventors - } \\
\text { Alexander Graham Bell - telephone } \\
\text { service }\end{array}$ \\
\hline $\begin{array}{l}\text { "Looking backward: They would close } \\
\text { to the new-comer the bridge that } \\
\text { carried them and their fathers over." }\end{array}$ & "The Chinese must go" \\
\hline $\begin{array}{l}\text { Uncle Sam's Lodging-House: } \\
\text { "Look here, you, everybody else is } \\
\text { quiet and peaceable, and you're all the } \\
\text { time a-kicking up a row!"-Uncle Sam }\end{array}$ & $\begin{array}{c}\text { "They turned her on her side and made } \\
\text { her a fence." }\end{array}$ \\
\hline $\begin{array}{c}\text { Tenement in a big city such as New } \\
\text { York or Chicago }\end{array}$ & $\begin{array}{c}\text { Settlement House such as Jane Addams' } \\
\text { Hull House }\end{array}$ \\
\hline Ghetto - children and a dead horse & $\begin{array}{l}\text { "The City Frauds" - } \\
\text { "Report of the Citizens' Investigating } \\
\text { Committee...Twenty Millions of } \\
\text { Dollars Found to Have been Stolen." }\end{array}$ \\
\hline
\end{tabular}


Final Student Interview Protocol

Thank you for agreeing to meet with me again today. Do you mind if I record our conversation again so I can accurately capture your responses? As before, please feel free to skip any question that you prefer not to answer.

The questions I want to ask today build on observations from throughout the course of the semester.

\section{Card Sort}

- We will begin with an activity. Please select five to ten cards that "best describe" you or are the "most important" to you. When you have made your choice I will ask you to explain how you chose those cards.

\begin{tabular}{|l|l|l|l|l|l|}
\hline Group 1 & Group 2 & Group 3 & Group 4 & Group 5 & Group 6 \\
\hline Boy & Activist & American & $\begin{array}{l}\text { African } \\
\text { American }\end{array}$ & $\begin{array}{l}\text { Arabic- } \\
\text { speaker }\end{array}$ & Other: \\
\hline Brother & Actor & Cuban & Asian & Bilingual & \\
\hline Daughter & Artist & Eritrean & Caucasian & $\begin{array}{l}\text { English } \\
\text { Learner }\end{array}$ & \\
\hline Friend & Athlete & Ethiopian & Christian & $\begin{array}{l}\text { English- } \\
\text { speaker }\end{array}$ & \\
\hline Girl & $\begin{array}{l}\text { Comedian / } \\
\text { Class Clown }\end{array}$ & Guatemalan & Jew & $\begin{array}{l}\text { Kurdish- } \\
\text { speaker }\end{array}$ & \\
\hline Sister & Environmentalist & Honduran & Muslim & $\begin{array}{l}\text { Spanish- } \\
\text { speaker }\end{array}$ & \\
\hline Son & Feminist & Immigrant & & $\begin{array}{l}\text { Tigrinya- } \\
\text { speaker }\end{array}$ & \\
\hline Student & Gamer & Iraqi & & & \\
\hline & Musician & Mexican & & & \\
\hline & Reader & Puerto Rican & & & \\
\hline & Writer & Refugee & & & \\
\hline & & Salvadoran & & & \\
\hline
\end{tabular}

Perspectives on U.S. History

- Class experiences

- What have you learned about so far this year in [teacher's name]'s class?

- What does [teacher's name] do in history class that you like?

- What have you learned in [teacher's name]'s class that surprised you?

- U.S. history (adapted from Epstein, 1998)

- Who are the three most important people in United States history? Why?

Did you learn about them last year in sixth grade?

o What are the three most important events in United States history? Why?

Did you learn about them last year in sixth grade? 
- Where is the most believable place to go to get information on history? In other words, where do you go who do you talk to to learn about history? Examples might your teacher, your family, books or TV.

- How is history you learned about at home different from the history you learned about at school?

Fieldnote Excerpts

- Example 1: [include excerpt]

○ What were you doing in this situation? When you were...?

- How do you interpret Student A's response to your question?

$\circ$ Why...?

- Example 2: [include excerpt]

$\circ$ How does this excerpt illustrate...?

- How do you interpret Student B's question in the context of their group assignment?

$\circ$ Why...?

Emerging Findings

- Finding 1

$\circ$ How do you...?

- Finding 2

○ Do you agree with...?

- Finding 3

“What should I have asked you that I didn't think to ask?” (Patton, 2002, p. 379)

Thank you so much for talking to me. I really appreciate it. 


\section{Appendix D}

Card Sort Results from Final Student Interviews

\begin{tabular}{|c|c|c|c|c|c|c|}
\hline Student & Group 1 & Group 2 & Group 3 & Group 4 & Group 5 & $\begin{array}{c}\text { Group } \\
6\end{array}$ \\
\hline $\operatorname{Aras}^{b}$ & $\begin{array}{l}\text { Boy } \\
\text { Student } \\
\text { Brother }\end{array}$ & $\begin{array}{l}\text { Athlete } \\
\text { Gamer }\end{array}$ & & Muslim & $\begin{array}{l}\text { English- } \\
\text { speaker } \\
\text { Kurdish- } \\
\text { speaker }\end{array}$ & \\
\hline Felix $^{b}$ & $\begin{array}{l}\text { Boy } \\
\text { Student } \\
\text { Friend } \\
\text { Brother }\end{array}$ & $\begin{array}{l}\text { Athlete } \\
\text { Actor }\end{array}$ & $\begin{array}{l}\text { Mexican } \\
\text { American }\end{array}$ & & $\begin{array}{l}\text { Bilingual } \\
\text { English- } \\
\text { speaker }\end{array}$ & \\
\hline Gebre $^{\text {bc }}$ & $\begin{array}{l}\text { Boy } \\
\text { Student } \\
\text { Son } \\
\text { Brother }\end{array}$ & \begin{tabular}{|l} 
Athlete \\
Musician \\
Reader
\end{tabular} & $\begin{array}{l}\text { Eritrean } \\
\text { Ethiopian }\end{array}$ & & Bilingual & \\
\hline Isabel $^{\mathrm{a}}$ & $\begin{array}{l}\text { Girl } \\
\text { Daughter } \\
\text { Friend } \\
\text { Sister }\end{array}$ & $\begin{array}{l}\text { Athlete } \\
\text { Musician } \\
\text { Artist } \\
\text { Reader } \\
\text { Gamer } \\
\text { Environmentalist } \\
\text { Feminist } \\
\end{array}$ & $\begin{array}{l}\text { Mexican } \\
\text { American }\end{array}$ & $\begin{array}{l}\text { Caucasian } \\
\text { Christian }\end{array}$ & $\begin{array}{l}\text { Bilingual } \\
\text { Spanish- } \\
\text { speaker } \\
\text { English- } \\
\text { speaker }\end{array}$ & \\
\hline Javier $^{a}$ & $\begin{array}{l}\text { Boy } \\
\text { Student } \\
\text { Friend } \\
\text { Brother } \\
\text { Sister } \\
\end{array}$ & $\begin{array}{l}\text { Artist } \\
\text { Comedian/Class } \\
\text { Clown }\end{array}$ & Honduran & & $\begin{array}{l}\text { Spanish- } \\
\text { speaker }\end{array}$ & \\
\hline Maria $^{a}$ & $\begin{array}{l}\text { Daughter } \\
\text { Friend } \\
\text { Sister }\end{array}$ & $\begin{array}{l}\text { Athlete } \\
\text { Comedian/Class } \\
\text { Clown } \\
\text { Actor } \\
\end{array}$ & $\begin{array}{l}\text { Honduran } \\
\text { American }\end{array}$ & & Bilingual & \\
\hline Marisol $^{\mathrm{a}}$ & $\begin{array}{l}\text { Girl } \\
\text { Student } \\
\text { Friend }\end{array}$ & & Salvadoran & & $\begin{array}{l}\text { English } \\
\text { Learner } \\
\text { Spanish- } \\
\text { speaker }\end{array}$ & \\
\hline Santiago $^{b}$ & $\begin{array}{l}\text { Boy } \\
\text { Student } \\
\text { Son } \\
\text { Friend } \\
\text { Brother }\end{array}$ & \begin{tabular}{|l} 
Athlete \\
Musician \\
Gamer
\end{tabular} & $\begin{array}{l}\text { Immigrant } \\
\text { Mexican }\end{array}$ & & & \\
\hline
\end{tabular}




\begin{tabular}{|l|l|l|l|l|l|l|}
\hline Student & Group 1 & \multicolumn{1}{|c|}{ Group 2 } & Group 3 & Group 4 & Group 5 & Group 6 \\
\hline Salvador $^{\mathrm{b}}$ & $\begin{array}{l}\text { Boy } \\
\text { Student } \\
\text { Son } \\
\text { Friend }\end{array}$ & $\begin{array}{l}\text { Athlete } \\
\text { Gamer } \\
\text { Comedian/Class } \\
\text { Clown }\end{array}$ & & $\begin{array}{l}\text { Bilingual } \\
\text { Spanish- } \\
\text { speaker } \\
\text { English- } \\
\text { speaker }\end{array}$ & \\
\hline Yonas $^{\text {ac }}$ & $\begin{array}{l}\text { Boy } \\
\text { Daughter }\end{array}$ & $\begin{array}{l}\text { Athlete } \\
\text { Reader }\end{array}$ & $\begin{array}{l}\text { Honduran } \\
\text { Eritrean } \\
\text { Ethiopian }\end{array}$ & $\begin{array}{l}\text { African } \\
\text { American }\end{array}$ & & \\
\hline Yousuf & $\begin{array}{l}\text { Son } \\
\text { Daughter } \\
\text { Friend }\end{array}$ & $\begin{array}{l}\text { Artist } \\
\text { Gamer }\end{array}$ & $\begin{array}{l}\text { Immigrant } \\
\text { American }\end{array}$ & Muslim & $\begin{array}{l}\text { English } \\
\text { Learner } \\
\text { Arabic- } \\
\text { speaker }\end{array}$ & $\begin{array}{l}\text { "Other- } \\
\text { people I } \\
\text { could } \\
\text { speak } \\
\text { other } \\
\text { language" }\end{array}$ \\
\hline
\end{tabular}

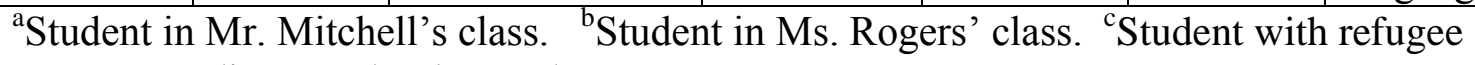
status according to school records. 